

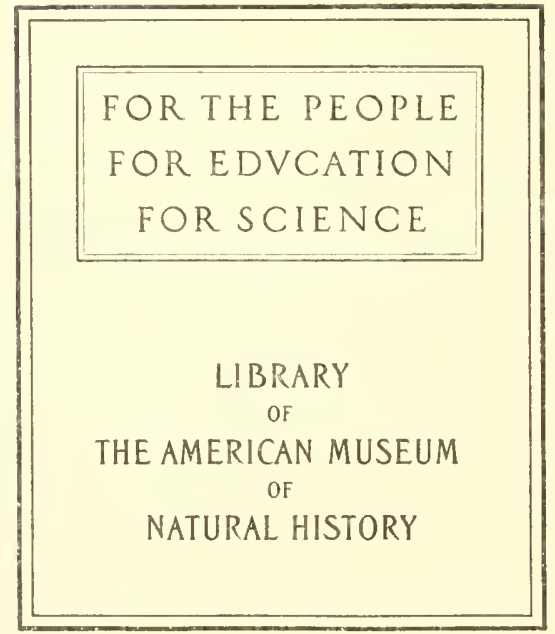






THE NATURALIST OF TIUE ST. CROLX

Complimants of

tho Sons of

Ecorge Q. Boardman. 




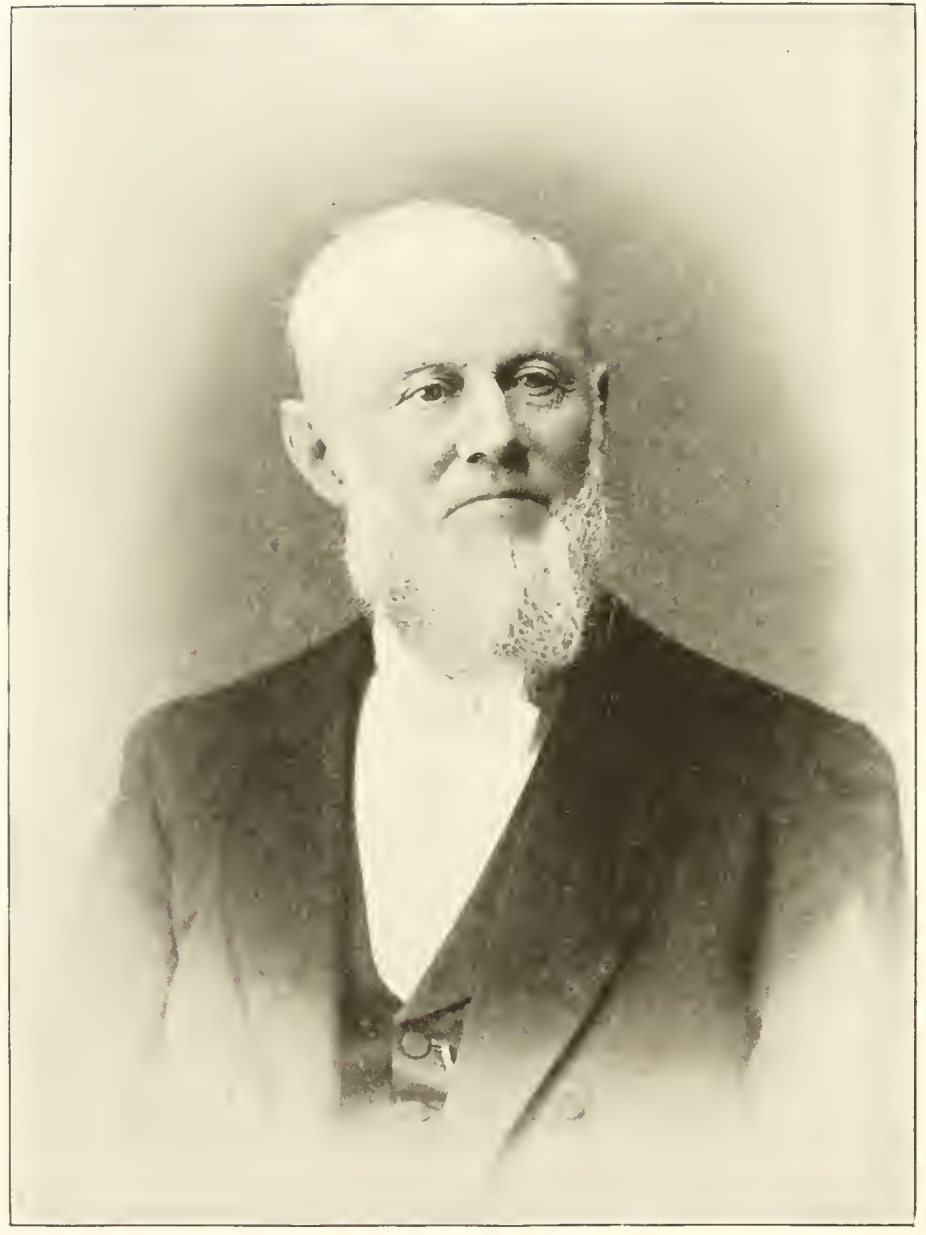


THI:

\title{
NATURALIST
}

\section{OF THE SAINT CROIX}

\author{
MEMOIR OF \\ GEORGE A. BOARDMAN
}

A SELECTION FROM HIS CORRESIONDENCE AND PUIBLSIIED WRITINGS, NOTICES OF FRIENDS AND CONTEMPORARIES WITI IIIS LIST OF TIIE

BIRIS OF MAINE ANI) NEW BRUNSWICK

B Y

SAMUEL LANE BOARUMAN, M. S.

Unicersity of Maine, Honorary, 1899

13A NGOIR

IPIVIVAELX I'IRIN'TED

1903 


\begin{abstract}
AN delighted to know that you have shot that black and golden winged woodpecker after which I have been seareliing so long. He has escaped me for about forty-eight years, but I am glad to get him now. I also do want that female pied duck. We do not possess either sex in the Smithsonian and want it very much. And please let me have that queer Labrador Duck with the bill that doesn't belong to it. We will immortalize Milltown. -Prof. Spencer F. Baird, Secretary of the Smithsonian Institution, Washington, D. C., in Letter to George A. Boardman, June 22, 1871.

Would it be possible to send the nest in a box so packed that it would be fit to paint from on arrival? I would employ Wolf to make a handsome painting of it with old and young birds, and you should have the first copy struck off, colored by Wolf himself. Please do help me in this and I will do all I can to immortalize you as the first who has enabled us to give full particulars of the breeding of this bird.-Henry E. Dresser, London, Eng., author of IHistory of the Birds of Europe, in Letter to George A. Boardman, IIay 27,1872 .
\end{abstract}


TO TIIE ORNITIOLOGISTS OF AMERICA:

7 THIS Memoir of one of the Pioneer Field Naturalists 1 of the United States, a plain man of business who traveled from the Atlantic to the Pacific and from the Mountains of the North to the Great Gulf of the South in his study of Birds; who gathered the largest private collection in ornithology and natural history of any citizen in this country; the accuracy of whose scientific knowledge was only exceeded by his noble cliaracter and beautiful life; Friend of Baird, Brewer, Cassin, Cones, Lawrence and Wood among the great ornithologists wlio have Passed and of Allen, Dresser, Elliot, Ridgway and Verrill among those who remain - is Respectfully and Lovingly Dedicated. 



\section{IN'TRODUC'TION}

TTHE present volume grew out of the belief on the 1 part of members of Mr. Boardman's fanily, as well as that of his many friends, that a life so successful in business; so largely devoted to a study of one of the leading branches of natural history; so rich in personal experiences and so true and noble in character, should not end and leave no record of what had been accomplished within the period of that life.

When the work was contemplated its plan was simple. It was designed to republish Mr. Boardman's lists on the fauna of the St. Croix, for which there had been much call from scientists, especially for his list of birds and to accompany its reissue in a new form based upon the latest authoritative nomenclature, with a memorial sketch of Mr. Boardman which would give some account of his life and of his service to science.

But when the material in hand had been exanined it was found to be so extensive in volume, so rich and valuable in character and so important to science that the original plan was clianged. The scope of the work was enlarged; a more careful memoir was decided upon; the use of Mr. Boardman's large correspondence, including the many letters from leading ornithologists, was to be drawn upon as showing the importance and progress of 
viii.

lis studies; as indicating the value which the great scientists of England and America placed upon his work, the high esteem in which his friendship was held, as well as his judgment consulted and depended upon by them.

Thus the rolume has grown as the material has been made use of. If it is larger than originally designed, the hope may be expressed that it is not too minute to satisfy Mr. Boardman's friends, while it wonld have been an easy matter to have made it more comprehensive.

There is yet a vast mass of unused material as entertaining as any that has been made use of, or that appears in the work. Among this material are many letters from our greatest and best known naturalists of Mr. Boardman's day, with unpublished notes and chapters on natural history subjects. These record Mr. Boardman's observations with great carefulness and in a style extremely graphic and interesting.

During the last few years of his life Mr. Boardman wrote much for the local newspapers of Calais and St. Stephen. While this was done as a matter of personal amusement the articles thus contributed were exceedingly entertaining. These extend to more than two hundred and are upon a wide range of subjects - those of current interest; relating to his own observations or the result of his wide reading; jects and upon topics that were engaging the attention of people of the two cities.

Of especial interest to residents of St. Stephen and Calais was a series of thirty articles or chapters, under the general heading: Early Times on the St. Croix. These consisted largely of Mr. Boardman's personal reminiscences. They embraced sketches of the early 
settlers; of the mills and shipping on the St. Croix; of the churches, schools, merchants and professional men; of the leading families and of the industries of the two cities. Although not sufficiently elaborate to be called history they form a most important contribution to history and 1nlust always be regarded when material for Calais and St. Steplien local history and biography is being collected. It was the original intention to republish them in the present volume but the idea was abandoned as one carrying the book far beyond its reasonable size. It became a question of including the historical sketches and excluding the rich correspondence or vice versa. To have included the sketches would have been gratifying to people in those two cities, although scientific readers would have regarded then of but little value. As the work progressed and became more especially a scientific memoir, it was deened best to sacrifice the historical chapters for the sake of the letters to and from Mr. Boardman and his naturalist friends. In his quiet life; in his love for home and the locality in which he lived; in his devotion to natural history and his interest in the antiquities, history and people of the St. Croix, Mr. Boardinan was a genuine type of the naturalist of Sclborne, and would have felt more satisfied to have been called the Gilbert White of Maine than that of any other title.

It only remains for me to express my obligations to those who have assisted me in the preparation of this work and to whom I wish to return my grateful acknowledgments :

First of all my thanks are clue to the sons of George A. Boardman wlose liberality has made possible the 
preparation of this memoir. They have not only borne the entire expense of its publication but have assisted me in many ways - given many suggestions, furnished numerous facts and also assisted me in obtaining much necessary information. They have greatly deferred to my judgment and seconded my every wish for making the volume the creditable work which it is hoped it will be found. 'To Mrs. J. Clark 'Taylor, Calais, Maine, the only daughter of Mr. Boardman, for the loan of the entire mass of his correspondence with naturalists, without wlich the preparation of this volume in its present form would have been impossible. 'To Prof. S. P. Langley, secretary of the Smithsonian Institution, Washington, D. C., for the loan of the collection of letters written by Mr. Boardman to Prof. S. F. Baird, now in the custody of the Institution; for the loan of the plate of portrait of Prof. Baird, as well as for many dates and facts and the kindly answer of numerous letters of inquiry. To Lewis Sperry, Essq., Hartford, Conn., and to Mrs. Mary Eilsworth Wood, East Windsor Hill, Con11., for the 11se of Mr. Boardman's letters to Dr. Wiilian Wood; for the memoir and portrait of Dr. Wood and for other important material. 'To Hon. P. W. Flewelling, of the Crown Lands Department, Fredericton, N. B., for much information relating to the transfer of the Boardman collection of ornithology to the Provincial government of New Brunswick and for personal interest in the work. To Robert Ridgway, curator of birds in the Smithsonian Institution, Washington, D. C.; to J. A. Allen of the American Museum of Natural History, Central Park, New York, and to Charles Hallock, Plainfield, Mass., for the use of letters of Mr. Boardman and to the latter 
gentleman for permission to reprint from lis volume, Camp Life in Florida, the clapter contributed to that work by Mr. Boardman. To Prof. Leslie A. L,ee, Bowdoin College, Brunswick, Maine, for collating the voln1mes of the American Naturalist. To Charles G. Atkins, superintendent of the Government Fish-hatching Station at Green Iake, East Orland, Maine and to his sister, Miss Helen Atkins, for collating the volumes of Forest and Stream. To Prof. Ora W. Knight, ex-President of Maine Ornithological Union, Bangor, Maine, for his interest in the work and for revising the list of St. Croix Birds to make it conform to the present scientific nomenclature. To the Forest and Stream Publishing Company, New York, for the use of the plate of portrait of Charles Hallock. Finally, I wish to acknowledge the assistance I have received from my wife, Mrs. Alma Staples Boardman. She has not only corrected the MS. but has collated and revised the scientific lists, read all the proofs, revised and re-revised the page proofs, made the inclex and had oversight of the typographical work involved, without which the volume could not have presented that freedom from errors which it is believed now characterizes it.

BANGor, Maine, June 12, 1903. 



\section{CON'TENTS}

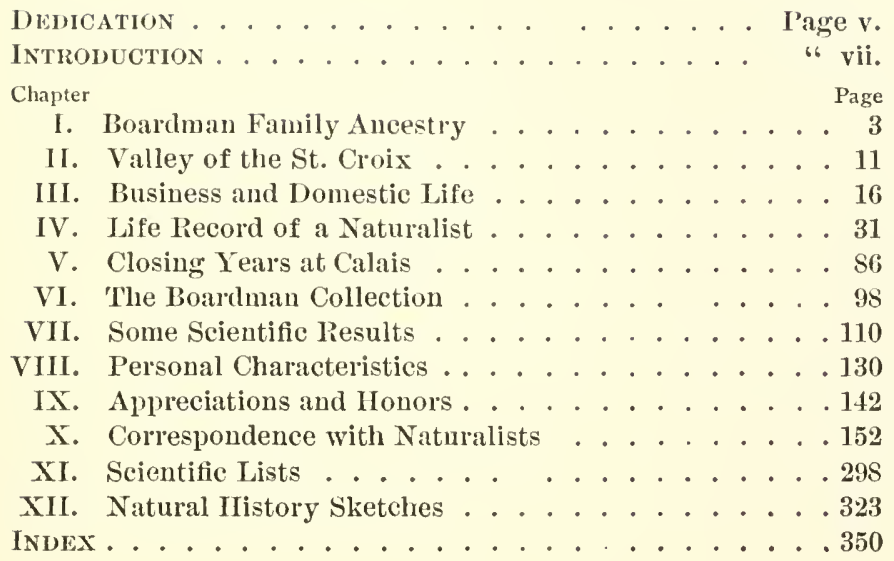





\section{LIST OF PIANTES}

I'ortrait of George $\Lambda$. Boardman . . . . . . Frontispiece

Portrait of Georre A. Doardman Page

Portrat of George A. Boardman . . . . . . . . . . 16

Residence of Mr. Boardman at Milltown, N. B. . . . . . 23

View from the Garden at Milltown, N. I3. . . . . . . . 24

Faesimile of Letter of Prof. S. F. Bairl . . . . . . . . 68

Portrait of George A. Boardman . . . . . . . . . . . 86

Last liesidenee of George A. Boardman . . . . . . . . . 88

l'ortrait of George A. Boardman . . . . . . . . . . . . 95

Boardman Family Monument . . . . . . . . . . . . 97

Interior of Bird Museum at Calais . . . . . . . . 98

Interior of Bird Museum at Calais . . . . . . . . . 101

Interior of Bird Mnseum at Calais . . . . . . . . . . . 105

Plan of Boardman Room . . . . . . . . . . . . . . 106

Parliament House, Frederieton, N. B. . . . . . . . . . 109

Group of Bear Cubs . . . . . . . . . . . . . 127

Portrait of Mrs. George A. Boardman . . . . . . . . . . . 132

Portrait of Prof. S. F. Baird . . . . . . . . . . . 154

Faesimile of Letter of I'rof. S. F. Baird . . . . . . . . . 160

Bird Musenm at Calais . . . . . . . . . . . . 185

Portrait of Dr. William Wood . . . . . . . . . . 213

Portrait of Henry E. Dresser . . . . . . . . . . . . . . . 249

Faesimile of Letter of Henry E. Dresser . . . . . . . . . 262

Faesimile of Letter of George A. Boardman . . . . . . . 272

Portrait of Charles Hallock . . . . . . . . . . . 281

Facsinile of Letter of P. L. Sclater . . . . . . . . . 293 

THE NATURALIST OF THE ST. CROIX 



\title{
THE NATURALIST OF THE ST. CROIX
}

\author{
CHAPTER I
}

\section{BOARDMAN FAMILY ANCESTRY}

\begin{abstract}
THE family name of Boardman is one of much 1 antiquity. Eariy forms of the name as found in records of both England and America are Boreman, Borman, Boarman, Burman, Burdman, Bodman, Boordman and Bordman. The family originated in Oxfordshire, England, where the first of the name, William Boreman, was living as early as 1525 , in Banbury, in that county. He had a son Thomas, called "the elder," who was living at Claydon, near Banbury, in 1546, whose wife's name was Isabelle. He died at Claydon in 1579. Thomas had a son William who was married, but whose wife died about five years before her husband - her death having occurred in 1608 and that of her husband in 1613. Their son Thomas - called in the records "the younger" - was baptized at Claydon, October 18, 1601. He was the first of the name in New England. The earliest tax list of the Colony of New Plymouth that has ever been found, bearing date January $2,1632-33$, contains his name.
\end{abstract}


In the Old Colony records of 1643 , in a list of all the males of New Plymouth Colony, "able to beare armes from xvi years old to 60 years," the name of Thomas Boreman also appears. He is there put down as a resident of Barnstable, Mass. Savage, in the Genealogical Dictionary of First Settlers of New England, says he was made a freeman March 4, 1635. He first appears on the records of Ipswich, Mass., in 1637. He was a cooper and carpenter by trade. The late Joseph $B$. Felt, one of the most learned and accurate antiquarians in New England, says he was first at Ipswich, that he moved from Ipswich to Barnstable but returned to Ipswich again. In his history of Ipswich Mr. Felt records that he died in that town in 1673 at an advanced age. His wife's name was Margaret. Some accounts say she died in November, 1679 ; but Mr. Felt gives her death as having taken place in 1680. Thomas Boreman's estate was valued at his death at $£ 5236$ s. $6 \mathrm{~d}$.

It may be interesting to give here the remarks of that learned antiquary, the late Rev. Lucius R. Page of Cambridge, Mass., in explanation of the different ways of spelling what is evidently the same name as found upon early New England colonial records, as a help to the understanding of the different forms of spelling the name Boardman as given at the beginning of this chapter. This author says: "It is not surprising that many of these names are incorrectly spelled. They are not autographs, but were written by the secretary or clerk according to the sound as the names were spoken to him. Moreover, it no doubt often occurred that the clerk did not catch the sound accurately and therefore mistook the true name." As many of the early settlers 
to New England were unlettered men, could not write, perhaps could not spell, they gave their names to the town officers as they were accustomed to be called, hence the various ways of spelling what is the same name, which appear upon the early records.

Thomas Boreman, eldest son of Thomas and Margaret, was born in 1643 and married Elizabeth, daughter of Sargent Jacob Perkins, January 1, 1667-68. She was born April 1, 1650. This Thomas Borenan died October 3,1719 , in his seventy-sixth year and his wife died December 4, 1718, aged sixty-eight years, eight months and three days.

Thomas and Elizabeth Boreman had a son Offin who was born at Ipswich, Mass., December 3, 1676 and married Sarah Hurd, February 28, 1698. Their son Offin was born December 16, 1698 and married Sarah Woodman, January 17, 1722. He was master of a vessel that, according to the records, "was overset" September 8, 1735, on a passage from Casco Bay to Bostont and himself and twelve others were drowned. His wife died July 12,1752 .

It should be stated here that Savage, in his Genealogical Dictionary of First Settlers of New England, says that "after 1720 the early name of Boreman became permanently changed to Bordman and Boardman."

Jonathan, son of Offin and Sarah (Woodman) Boardman, was born March 15, 1735 and married Rebecca Moody, November 12, 1761. They had a son William who married Mary Short, September 19, 1786. He was master of a vessel and was lost at sea. Two letters written by William Boardman to his father are in possession of a member of the family. The first is dated St. Lucia, 
January 10, 1793 and the second at Wilmington, March 10, 1793. Both letters are interesting and indicate the greatest respect for his father and devotion to his interests.

In the first letter he writes: "The 30th of December I arrived at Point Petre Saw Brother Chase. Markets Would Not Due from there I went to St Peires from There to St Lucia And have Sold here. Lumber at 15 Dolars Beff at 8 Dollars Shingles at $1 \frac{1}{2}$ Dolars Mackrell at 4 Dollars. To Be payd one Third part in Cash The Other Two Thirds in Sugar Coffee Coaco Cotton At cash price. Sir I had Acounts from St Astaita Lumber Will not Answer there. Sir I expect to Sail by the 10 of february. If Any Thing Should happen That I Should Be Detained any Longer I Shall prosead to Newbury port. If not I Shall go to Willmington. I had Very bad Weather on my pasage the 11 Decembr Scut Under 2 Rt forsail had my Quarter Boards Nock away my Chimney Nockd Down And my Lumber Shifted 16 Inches Of Water for 2 Hours in The Hold By Baging the pump Boxes We freed her And fortingly Saved our Deck Load I Shall Due the Best I Can for your Intrist So Conclude Remaining your Loving Son." He then adds this P. S: "We are all Well I have Landed my Deck Load I have Sold to Mr Nervear and Company By What I Can hear they are Good men." 'This letter was directed to "Capt Jonathan Boardman in Newbury Port by favour of capt Spitfield."

The second letter is as follows: "Loving Sir I Write to let you now that after a passage of 13 Days I arrived here my Westingss Goods are not Wanted here Lumber and Navill Stores are too hy for me to purchas Atpresant 
I Cannot Git no freight here for no plase. If nothing Offers Before to Morrow Noon I must Leave or Enter my Vesell. I Rather think I Shall Leave this port and prosede for Newbury Port. Sir I now I Shall make a Bad Voiage If I come home and I Shall make a Worse If I Stay here and It is one half to own it Sir I have Wrote to you By Capt Hollon and Capt. Yong of Portland Before Sir So have nothing New to Inform you of more at Present Remember me to my Wife and the family And all Inquirings friends I Remain your Dutifull Son William Boardman."

This is the last that was ever heard of Capt. William Boardman, his vessel and all on board having been lost at sea while on the passage from Wilmington, N. C., to Newburyport, Mass., in the spring of 1793. Mary, the wife of William Boardman, died April 27, 1847.

William, the son of William and Mary (Short) Boardman, was born in Newburyport, Mass., May 30, 1789 and married Esther W. Toppan March 12, 1815. She was born June 28, 1793 and was a daughter of Stephen Toppan who descended from Abraham Toppan who settled in Newburyport as early as 1637. Mr. Boardman was in business in Newburyport for a few years and moved to Portland in 1820. In 1824 he moved from Portland to Calais where he engaged in trade, bringing his family in 1828. Mr. Boardman was a Mason and was treasurer of St. Croix lodge, Calais, on its organization in 1844. Mr. George A. Boardman, writing in one of his delightful autobiographical sketches printed in the St. Croix Courier, tells of the anti-Masonic "mania," as he terms it, which prevailed in the early ' 30 's and says: "So intense was the feeling at one time that 
bloodshed was feared and the lodges ceased to hold meetings. From what I heard and read I should have thought all the Masons should have been hanged if my father had not been a Mason. But my father told me the institution was a good one and friendly to the best interests of humanity; that bad men sometimes join the fraternity as unworthy men sometimes join the churches, but the influence of the lodge was for good and good only. Ever since then I have had great respect for the order." This incident shows the influence of a good man's life upon character. William Boardman was a good man; his son believed in him and his good character influenced that of the son to honor and respect not only the man, but any institution to which he belonged and endorsed. William Boardman joined the first temperance society which was organized in Calais, May 12, 1828 - the very year in which he brought his family to that town.

The children of William and Esther (Toppan) Boardman were Adeline who married F. H. Todd; William H.; George A.; Caroline M., who married Charles Hayden of Eastport; Anna L., who married Henry F. Eaton; Gorham, who resides in New York; Mary E., who married Rev. Henry V. Dexter, and Emily who married Elwell Lowell and resides in Calais. Willian Boardman died July 2, 1866; his wife Esther died May 31,1877 . On the death of Mr. Boardman, the following notice appeared in the St. Croix Courier and was republished in the Newburyport Herald of July 17, 1866 :

"Perliaps no one has more generally endeared himself to the whole community than he, by his obliging qualities of character, his amiable and cheerful disposition, 
his gentle and courteous manners. With a keen insight into luman nature, he was yet so full of love and charity that no one living can remember of him an unjust or an unkind word. All, even the little child, were made happier and better by his loving, cheerful presence. To his large family lis loss will be very great; for his life to them has been a continual benediction. The same smile, the warm grasp of the hand, the loving words of welcome were never forgotten until strength and memory failed. Blessed beyond words has his pure life been to them. May the mantle of his charity and cheerful faith enwrap them all as they leave him in repose and again mingle in the turmoil of life."

Before closing this chapter it may be of interest to mention - although this memoir is in no sense a genealogical history of the family — that Savage says that Daniel Bordman who was married at Ipswich, Mass., April 12, 1662, "was a brother of Thomas called Boreman; and also Samuel Boreman (Borman, Boardman) who was at Ipswich in 1639 and who went to Weathersfield, Conn., in 1642 and founded the Connecticut family of Boardmans, who was a brother of Thomas, who settled in Ipswich in 1634." It is the purpose of this memoir only to bring down the family branch from which the naturalist of the St. Croix descended, but the above is mentioned as an interesting fact in the family history.

The parents of George A. Boardman lived to celebrate their golden wedding as did lis brother William, who married Mary Quincy, who celebrated their golden wedding August 5, 1890. His sister Amna and husband, Henry F. Eaton, celebrated their golden wedding October 17, 1892 and Mr. Boardman celebrated his December 19, 


\section{THE NATURALIS'T OF THE ST. CROIX}

1893. His brother Gorham and wife, Mary L. Lord, celebrated their golden wedding October 23, 1901. This record shows that father and mother and four of their children lived to observe their golden weddings. This is a somewhat remarkable record for longevity in one family - a family remarkable for devotion and love to their own kindred, for interest in humanity and in all agencies and efforts making for the common good. 


\section{CHAPTER II}

\section{VALLEY OF THE ST. CROIX}

THE St. Croix river-the natural valley of which 1 Mr. Boardman did so much to develop, in which his great business abilities were so long employed for its advantage and the fauna of which he made so well known to the scientific world - forms the boundary between the province of New Brunswick, Dominion of Canada and the United States, from a point just south of latitude 46 degrees north to the bay of Fundy into which its waters discharge. At Quoddy Head the United States reaches its farthest eastern limit and the St. Croix system is the most southeastern river system in the State of Maine. The area drained by the river St. Croix and its affluent lake systems is 70 miles long by 50 miles broad, having a total surface of 1175 square miles, 800 of which are in the State of Maine and 375 are in the province of New Brunswick. The St. Croix is formed by two branches, the lower of which receives the waters of the Grand lakes and the upper of which receives those of the Schoodic lakes - the connecting rivers being wide and voluminous. In the St. Croix system are 183 streams and 61 lakes represented upon 
the state map - eleven of the lakes and ponds being located in New Brunswick. The Indian name Schoodic, which denotes in the native tongue "low, swampy ground" is applied to the St. Croix in general, including its chains of lakes and streams. The entire system of rivers, streams and lakes forming the St. Croix is, in fact, an attenuated combination of the lakes; while by some the St. Croix has been termed "a lake in motion."

For about ten miles above tide water at Calais the river has an average width of 500 feet; its annual discharge is estimated at $44,800,000,000 \mathrm{cubic}$ feet ; the average fall to tide water is about 300 feet, or 6.5 to the mile and the land bordering the river and its tributaries is to a large extent low, preventing excessive rises upon the river itself - conditions which, according to the report on the Hydrographic Survey of the State, " places the St. Croix at once and without controversy in the foremost position of the large rivers of Maine as a manufacturing stream." The same authority, in 1869 , says that "fourfiftlis of the basin area of the St. Croix are covered with forests which consist largely of heavy, valuable timber."

A region of country possessing so many natural advantages for business early attracted the attention of settlers. The forests of beautiful timber were waiting to be transformed into merchantable lumber; the numerous falls invited the erection of dams and the building of mills, while tide-water at the upper arm of Passamaquoddy bay, which has a rise and fall at Calais and St. Stephen of twenty-five feet, making the river navigable twice every twenty-four hours for the largest vessels, brought these crafts there from many parts of the world for 
the products of the forests. Fish and game abounded and the forests and waters were alive with singing birds, game birds and water fowl. St. Stephen, N. B., opposite Calais, Maine, was settled between 1776 and 1779 ; while in 1780 a settlement was made in the southern part of Calais. Some years previous to the above dates white men had located on the river, but it is probable that the first permanent settlements were made in the above years. Among the first things these early settlers did was to build saw mills and lumbering soon became the most important industry. As early as 1790 a saw mill called the "brisk mill" was built by Peter Christie, Abner Hill and others. This was built at what is now called Milltown. It is an interesting fact that the lumber of which the old state house in Boston was built was sawn in this "brisk mill" and shipped from the St. Croix in 1795. A large business was also done at these early mills in getting out masts and ton or square timber for the English market and for the West India trade. The entire river on both the English and American sides was lively with saw mills and there were no less than twentyfive firms engaged in the business of manufacturing and shipping lumber; among them the great names of Christie, Hill, Todd, McAllister, McAdam, Eaton, Boardman and Murchie take high rank. Indeed, no more remarkable group of business men have been produced in any section of the provinces or the states than those who rose to affluence and power by virtue of their ability in developing and gaining control of the vast lumbering interests of the St. Croix valley during the last half century.

St. Stephen, N. B., and Calais, U. S. A., lie on opposite sides of the St. Croix at "salt water" or the head of 


\section{THE NATURALIST OF THE ST. CROIX}

navigation. Two miles up the river on the English side is the town of Milltown, parish of St. Stephen; while opposite on the American side is Milltown-Calais. On either side there is an almost continuous settlement the entire distance, while about midway is a bridge across the river and a number of mills which place is called the Union. The drive from Calais to Milltown on the American side and down to St. Stephen on the English side, or a ride by the well-managed trolley line of street cars is one of the most picturesque and interesting in any part of the states or the provinces. The cities are busy, the wharves piled with lumber, the harbor gay with vessels bearing the flags of two nations, while the lumber mills, the big cotton mill, the Washington County railroad and the belt line railroad connecting the Canadian Pacific railway with the former road give evidence of business prosperity and general content unsurpassed by almost any section of the country. The scenery is beautiful, there are fine residences all along the river banks, while the people of the two nations are really one. In business interests, social relations and all that makes for the public good, the residents of the two nations have a unity of spirit and interest that is indeed most friendly and serviceable.

It was in this beautiful and favored section where Mr. Boardman began his business life at the age of thirteen years. During his active business career and his long life as a private gentleman of wealth, public spirit, cultivated tastes and leisure, he became closely identified with the two communities in all their business, educational, religious and social interests. He loved the place and the people. He had studied them, lived 
among them and became a large part of them. He saw the towns become cities; he planned and carried forward large enterprises; he made his home in the beautiful valley and gave great study to its flora and its fauna. He knew the trees, the flowers, the song and game birds, the animals, the fishes. He numbered his friends at liome by the populations of the towns in which he lived, while his correspondents were among the greatest scientists of the time. He spent here a long, joyous, active and successful life. It was the dearest spot of all the earth to him and his life was devoted to making it dearer and happier to those whom he loved. 


\title{
CHAPTER III
}

\section{BUSINESS AND DOMESTIC LIFE}

\begin{abstract}
FORGE AUGUSTUS BOARDMAN, son of U William and Esther (Toppan) Boardman, was born in Newburyport, Mass., February 5, 1818 and came to Calais with his parents in 1828. All the education he ever received was the little in his early childhood and that obtained during the scanty terms of a Maine country school at that early date between the age of ten and thirteen years, with one term at Newburyport. After the family had settled in Calais he went back to the place of their former home where he attended school during one winter, making his home with members of his mother's family. At the age of thirteen years he left school to go to work and after that never had but one term at school nor did he take a course of study in any branch of education. At that time he engaged as clerk for Mr. Henry Hoyt with whom he remained a year. $\mathrm{He}$ was faithful and worked constantly for the interests of his employer. This was one of the earliest characteristics developed in the business career of the young man. After this first year of work he went into the store of Mr. B. F. Waite, one of the early merchants of Calais and
\end{abstract}




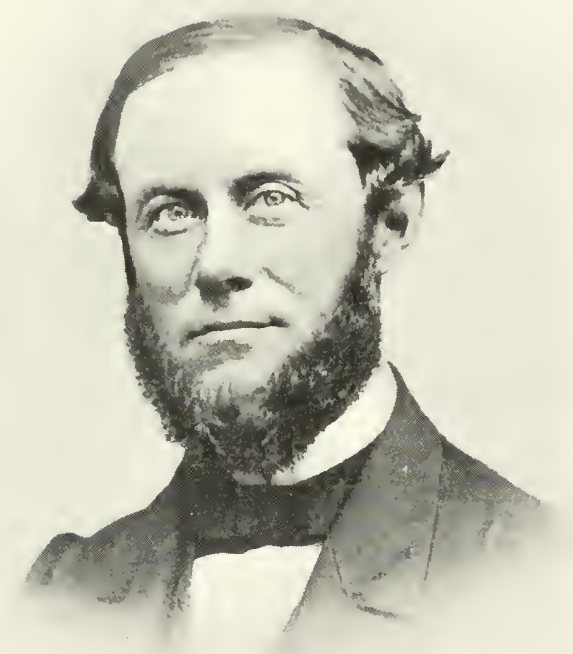

GEORGE A. BOARDM IN

At the Age of abont Thinty-six years 

an extensive lumberman, as a clerk, where he remained for a period of five years.

In an article describing early days on the St. Croix, written after Mr. Boarclman had retired from business, in which he describes the ways of the people and the domestic customs of the times, he says: "Tlhe writer was 'put to a store' in 1832 to learn the business. The most of the business was to sell liquor. The West India rum was brought in hogsheads and I was ordered to draw off one-third the hogshead and fill it up with water. The New England rum was treated about the same way." He then gives an account of the early temperance reform, telling of a public meeting at which Mr. William Todd, Jr., had made a speech closing with the words: "I have made up my mind to pledge myself to sell or use no more liquor and to use my influence to drive it out of the place and the world. Now who will join me and do likewise? "'

The account then continues: "Mr. B. F. Waite, who, in the last year, had retailed twenty-three hogsheads of West India rum said: 'I will go with you and sign that pledge.' "' In another article written in after life, in which he says that it had been his study to mark boys who had started in any grade of life to see how they had developed and what success they had reached, he said: "If a boy does not follow the right path before he is of age, it is not likely he will ever travel therein. Every boy over ten or twelve years old is either making or losing money every day, whether he is receiving any cash payment or not." Following this with the words, "let me explain," Mr. Boardman then gives this most interesting account of his own early life : 


\section{THE NATURALIST OF THE ST. CROIX}

"I knew a boy, son of a poor man, who was faithful to his parents and did every task given him. When but thirteen years old a nearby merchant asked him if he would not like to come to his store as clerk, saying, 'I have been watching you for a year or two and think you would suit me.' He was engaged for a year which he served out faithfully. Another merchant had been watcling this boy of fourteen years and engaged him in his employ, where he remained for five years at high wages. About this time a neighboring merchant, whose partner had retired, told this young man that he had been watching him for five years and if he could be spared by his present employer he would give him a good chance and perhaps make him a partner in his business as soon as he became of age. This was arranged and the next year, 1839, when he became twenty-one years old, he was made a partner in the best and largest lumber concern on the St. Croix river." Then, as was Mr. Boardman's way in all his entertaining writings, he enforced the moral of this incident by saying: "Did not this boy make money every day when the rich men were watching him? His faithfulness to little things - to all things that came in his way - was what made a fortune for him, as it would for any other boy who acted similarly. Somebody will tell other somebodies, until the boy's character is known as far as he is known."

Sucl is a true picture of the starting in business life of George A. Boardman, from his own pen. The man who had watched the boy so closely and taken so deep an interest in him on account of his faithfulness to his employer's interests was Mr. William Todd, one of the early pioneers and business men on the St. Croix river. 
Mr. Todd was born in North Yarmouth, Maine, July 10, 1803, his father, Mr. William Todd, having been a native of Goffstown, N. H. The family came to St. Stephen in 1811 and, in early manhood, Mr. William Todd entered upon a business career in Milltown which he followed with great success for many years. He was chiefly engaged in the nuanufacture and exportation of lumber, but was active in every movement and enterprise that had for its object the derelopment and prosperity of the country in which his home and business were located.

After the relinquishment of his business to his successors Mr. Todd largely gave his attention and money to the promotion of enterprises for the building up of the town. He was one of the first promoters of a railroad in the St. Croix valley; was for many years president of the St. Croix and Penobscot railroad company, the first president of the St. Stephen branch railroad company and a director and president of the St. Stephen bank. $\mathrm{He}$ was much interested in Provincial politics and in 1854 was appointed to a seat in the Legislative Council of New Brunswick and was an earnest advocate of provincial confederation. Mr. Todd was one of the founders of the Congregational cliurch at Milltown, for many years an office-bearer anci superintendent of the Sunday school. He was also president of the Bible society and a firm temperance advocate. On August 5, 1873, Mr. Todd died, full of years and of honors.

When Mr. Todd said to young George Boardman, after he had been in his employ for two years, "I want you to go into partnership with me," the reply was, "I have no money, I have given my money to my parents." 


\section{THE NATURALIST OF THE ST. CROIX}

And it is a splendid illustration of his love and respect for his parents, as well as a tribute to his habits of thrift and economy, that previous to his becoming of age he had given his father the sum of $\$ 1500$. Mr. William Boardman had lost his property in the eastern land speculation and had a large family to rear and educate. Beside paying his own board and expenses out of the small salary he had received - small at that early time in comparison with what young men receive nowyoung Boardman had saved and given to his father $\$ 1500$ of his own earnings to help him in his time of need. Could there be any doubt that such a boy would make a successful business man, or is it any wonder that Mr. Todd wanted him for a partner?

It was a most fortunate and happy beginning in business life when Mr. Boardman became a partner in the firm of William Todd, Jr. \& Company. This firm had previously been Todd \& McAllister, the members being William Todd and John H. McAilister, the latter of whom married Mr. Todd's sister who was Mrs. Boardman's aunt. The other member of the firm was Mr. Samuel Darling who had been in Mr. Todd's employ as book-keeper. Mr. Darling retired in a few years and went into business for himself. The firm of Todd \& Company was one of the largest and richest lumber firms on the St. Croix river.

On October 27, 1810, just after he had reached his majority, Mr. Boardman became a nember of this large and wealthy firm and his future success was at once assirred.

During the period between the years 1840 and 1845 the firm had a large and increasing business and enjoyed 
great prosperity. New nills liad been built, the sales of lumber had been extensive and prices were good. It was during the first years of the firm of William Todd, Jr. \& Company that Mr. Boardman induced his partner to put in the first gang mill on the St. Croix. He had heard of such a mill near Bangor, went out to see it and induced the firm to put one in operation. This was at the same place as what was afterward known as the "big gang," in the outside nill sold by the C. F. Todd estate to H. F. Eaton \& Sons. Before that all the mills in the Province were the old fashioned, slow, single-saw mills and the introduction of the gang saw revolutionized the manufacture of lumber on the St. Croix. In these improvements and the increased business Mr. Boardman had become an efficient factor in the firm's success. Now was to come another happy and important event in his life.

On December 19, 1843, * Mr. Boardman was united in marriage with Miss Mary J. Hill and commenced housekeeping in a small cottage which he had built that year. For the lot of land upon which this cottage was built Mr. Boardman paid $\$ 700$. It is a small story and a half

\footnotetext{
*Among the papers found in Mr. Boardman's collection of MSS, is the following in pencil, apparently of a date but a short time previous to his own decease: "Names of persons attending the Wedding of George A. Boardman and Mary J. Hill, *Dec. 19, 1813, at Milltown, St. Stephen: Mr. Johnson Officiated ; * Gorham Boardman, Groomsman; Eliza Ann Todd, Bridesmaid; Grandfather and Grandmother Todd ; ** Grandfather and Grandmother Hill ; ** Father and Mother Boardman ;** Father and Mother Hill;** Mr. and Mrs. Darling;* Mr. and Mrs. Dr. George ;* Mr. and Mrs. William Todd ; *** Aunt Laura and Elizabeth McAllister;** Mr. and Mrs. F. H. Todd; ** Mr. and Mrs. William H. Boardman; * Mr. and Mrs. Charles Hayden;** Mr. and Mrs. H. F. Eaton;** Edwin, Mary and Emily Boardman; Mrs. Amanda Hill ; * Alice Darling;* Abner,* Laura and Charles E. Hill; Frank,* Eliza Ann,* Hester and Ada Hill; Robert Todd, Jr; * Monroe Hill ; Mary Hill (Tobin); * Aseneth Hill (Atwood)." The asterisks in this note indicate the persons who had died up to the time Mr. Boardman wrote the same.
} 


\section{THE NATURALIST OF THE ST. CROIX}

house and is still standing on Main street, Milltown, N. B., though in a somewhat dilapidated condition. This house is nearly opposite the Congregational church which Mr. and Mrs. Boardman attended and into this cottage they moved the day of their marriage. Mr. Boardman had become a nember of this church in early life and was constant and devoted in his ministrations upon its services.

Mr. Boardman, by his own marriage and those of his sisters, became connected with most of the prominent and wealthy families of the St. Croix valley. His wife was the grand-daughter of Mr. Abner Hill, in his time the principal lumber manufacturer on the river, while his sons Abner, Daniel and Horatio were all at one time large lumber manufacturers and merchants. Another brother, Mr. George Stillman Hill, was said to be the ablest member of the Legislative Council of New Brunswick-he was a prominent lawyer and lived in St. Stephen. One of the earliest permanent settlers of Calais was Mr. Daniel Hill, a relative of Mrs. Boardman's grandfather. Her mother was a Todd and the Todds were all prominent, able business men and merchants. Mr. William Todd, as has been stated, was Mr. Boardman's partner in business. Mr. Freeman H. Todd, another brother, a man of great ability and force, who married Mr. Boardman's oldest sister Adeline, was a very sticcessful merchant, president of St. Stephen bank and of the New Brunswick and Canada Railway Company. Mr. Todd at his death, left probably the largest estate of any man in the province of New Brunswick. Mr. Boardman's sister, Anna L., married Mr. Henry F. Eaton, respected for his integrity and who, 



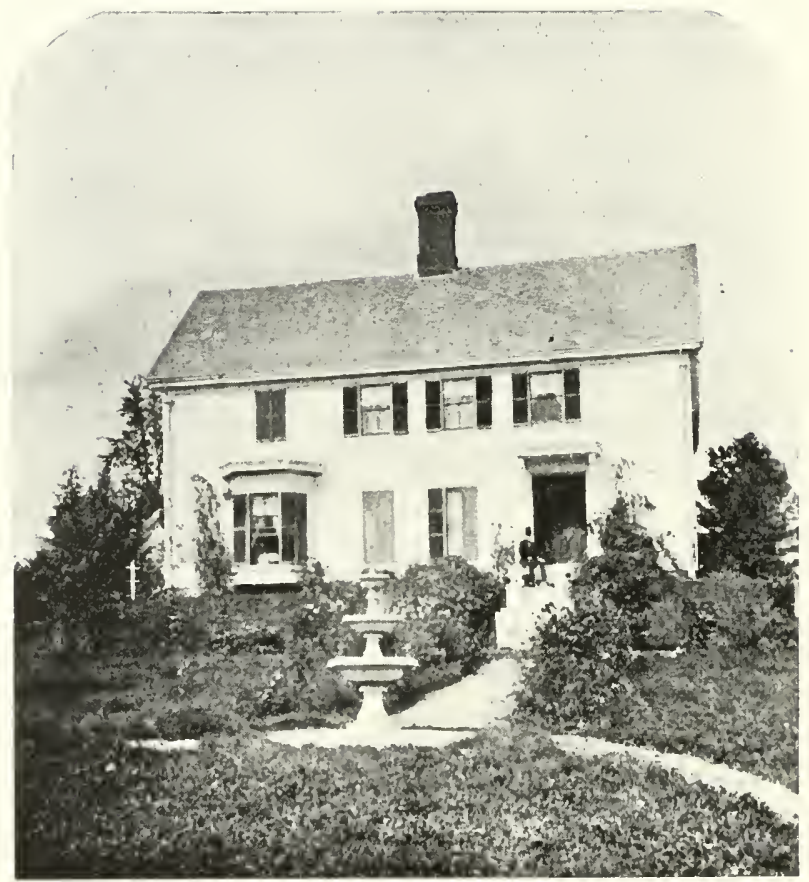

RESIDENCE OF GEORGE A. BOARDMAN

Milltown, St. Stephen, X. lB. 
by his ability and close application to business, left one of the largest estates ever probated in Maine, among the assets being 586,000 acres in fee of unencumbered timber land. Mrs. Boardman was born in the old house at the foot of Todd mountain, or Boardman mountain in Milltow11, N. B., which house is now standing.

The first store in which Mr. Boardman's firms did business on Water street, Milltown, N. B., is yet standing, with the mills in the rear, next to the river, but the mill and buildings are inucl decayed and are now unoccupied. There have been many changes on the river and mills and bridges have been carried away by freshets or destroyed by fire. The last mill owned by Mr. Boardman stood on what is known as the upper dam, in the rear of the old store.

Mr. Boardman remained in the firm of William Todd, Jr. \& Company until the year 1855. Mr. 'Todd's son, Mr. Charles Frederick Todd, had graduated from Bowdoin college the year previous and the following year Mr. Todd transferred his interest to his son. The firm then became George A. Boardman \& Company. As soon as Mr. Todd became acquainted with the business Mr. Boardman gradually gave the management of the firm to hinl. When he began to give less attention to it himself he paic the salary of Mr. Ezra Malloch who had been employed by them for several years. Mr. Boardman was then becoming greatly interested in the study of ornithology and was giving less attention to the business of the firm than formerly.

During the continuance of the firm of George A. Boardman \& Company its business increased greatly from year to year. More mills were erected, large tracts 


\section{THE NATURALIST OF THE ST. CROIX}

of land and timber were purchased and great shipments of sawed lumber were made to ports in the United States, the West Indies, South America and other foreign parts. Business called him frequently to New York, Baltimore, Philadelphia, Boston and other places at which times he made many acquaintances among business and scientific men. He continued to reside in the cottage house which lie built the year of his marriage, until 1860, when he built a new house at the corner of Main and Church streets, Milltown, N. B. This is a two-story house and its location is very pleasant. From its lawn a wide and beautiful view of the St. Croix valley is obtained, the outlook being upon the American side of the river in the state of Maine, directly opposite the famous salmon falls. As shown in the accompanying plate, the view is one across fine fields with their neat houses and beautiful trees. Mr. Boardman took great delight in this scenery, the near prospect of which was interesting as it included the pleasure grounds of his own home.

The years spent in this house were among the best and happiest of Mr. Boardman's happy life. It was here that several of his children were born and where they developed to years of young maturity. When at boarding school and college they came home at vacations bringing their college mates with them the house was the scene of great merry-making and good cheer. It was during his residence here that Mr. Boardman made the larger part of his collections and where the most active years of his business life were passed. He gave his time largely to natural history study and collecting, while Mrs. Boardman's time was devoted to her children, her home and her garden. 


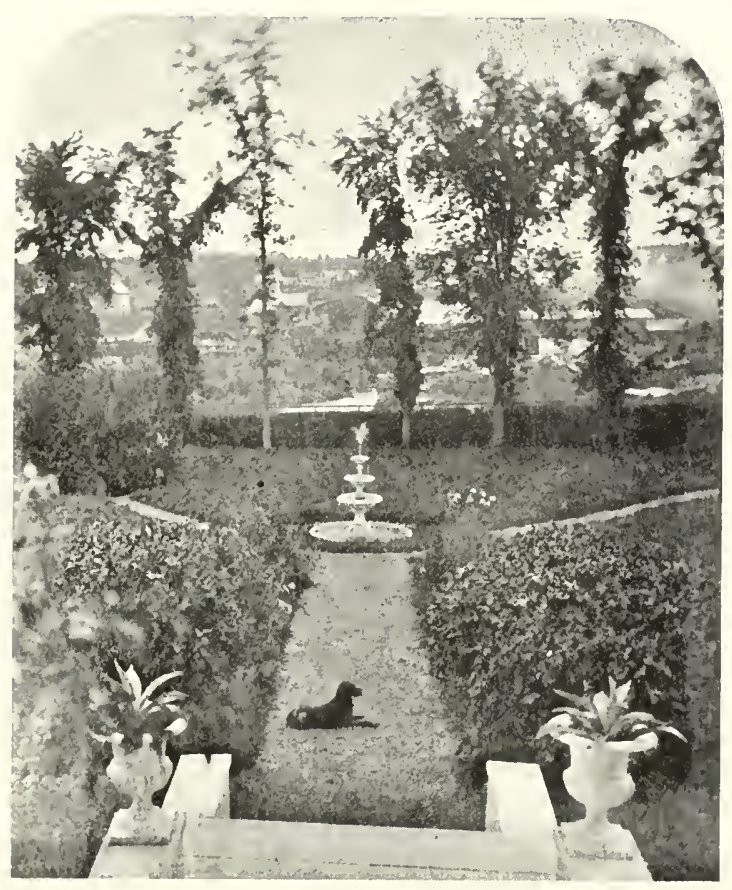

VIEW FROM THE GARDEN

At Ml. Boardman's Milltewn hesidence 

In Mr. Boardman's marriage he was most happy. No more noble woman ever lived than Mrs. Boardman. She was a person of great strength and loveliness of character, of fine presence, tall and commanding with a sweet face and a winning personality which drew to her friends from every station in life. As one who knew her intimately througliout life said: "She was born an angel and always lived one" - which is but a just tribute to her sweet disposition and beautiful character. Her entire life was given up to her family, her cliildren and her lome duties. She loved flowers and had at this Milltown home the finest and best kept garden and collection of plants of any one in that section and spent much time in their care. In all her husband's business pursuits and nature studies she was deeply interested, and after an ideal married life of fifty years Mrs. Boardman passed away, leaving behind to husband, children and friends the memory of a loving and devoted wife and mother. Near this house Mr. Boardman owned large fields of productive land which extended back from the river, on which he raised good crops; near here his mills were located, while he was interested in many of the dams and power privileges on the St. Croix. Water was brought to the buildings and grounds from a spring half a mile distant and every convenience possible was added to them that would make them desirable and pleasant.

In 1867 Mr. Boardman's eldest son, Charles Augustus, then twenty-three years of age, entered the firm of George A. Boardman \& Company. He had graduated from Bowdoin college the year previous. In 1870 his second son, Frederic Henry, who graduated from Bowdoin in 1869, was admitted, each taking one-half their 


\section{THE NATURALIST OF THE ST. CROIX}

father's interest, the firm name remaining unchanged. But while giving up interest in and care of the business he always liked to be active and constant about the mills and offices when not absent from home on his many visits.

For ten years previous to the admission of his sons into the firm, Mr. Boardman had been giving more and more time to the study of natural history, especially to ornithology. He had several times visited Boston, New York and Washington to meet naturalists and to visit the museums and was also engaged in correspondence with eminent scientists. Consequently he was placing more of the cares of business upon other members of the firm, especially upon his two sons who had taken his interest in the business. But while relinquishing these details of private business that he might devote more time to scientific pursuits, Mr. Boardman retained an interest in all public affairs and in the directorate of many corporations in which he had large financial interests. He was a director and president of the Ferry Point Bridge Company; of the International Steamboat Company; of the Frontier Steamboat Company, of which he was an original director and was president of the company at the time of his death; of the St. Steplen Bank and of the St. Stephen Rural Cemetery. He was also treasurer of St. Stephen academy from the time it was established till public schools were started in New Brunswick. These several corporations demanded much of his time and during a long business career it was very rarely that he was absent from any of their directors' meetings.

Between the years 1868 and 1891, a period of twentythree years, much time was spent by Mr. Boardman and 
his wife in visits to different parts of the country. While in active business he always took his own vacations in the winter time. During the summer months he managed the large business interests of his firm, giving his partners opportunity to have their vacations in the summer. He gave oversight to the mills of the company and made repeated visits to Boston, New York, Philadelphia and Baltimore to make sales of lumber and collections from buyers-such business being then done more personally than in later years.

When Prof. Baird of Washington was spending the summer of 1869 at Eastport with his family, and was planning for Mr. Boardman to join him on a trip to Grand Manan to pass some days in examining shellheaps and in hunting for Indian relics, Mr. Boardman explained why he could not accompany him. Writing to Prof. Baird under date of August $2 S$ of that year he says: "I am very sorry I cannot get away to go with you, but we have so many men at work, our mills are being repaired, there are letters and telegrams to answer every day and it is impossible. My partner, Mr. Todd, has been away for some time with his family and as I take my vacations in the winter I cannot spare the time in summer to be absent from business." This attention to business, however, did not prevent him from having a great deal of company in summer and his house was full of scientific friends for weeks at a time.

In the period covered by the years 1868 and $1891 \mathrm{Mr}$. Boardman made seventeen visits to Florida, most of them embracing the entire winter months. On several of these visits Mrs. Boardman accompanied hin. He also visited California and the west several times, spent 
a number of winters in Minnesota and made some winter visits to Clifton Springs, N. Y., at the sanatorium in that place whose proprietor, Dr. Foster, was an intimate friend of Mr. Boardman. Mr. Charles A. Boardman, Mr. Boardman's eldest son, lived in Florida a number of years where he was largely interested in railroads, orange growing and hotels and it was there his parents spent several winters with him. In the course of business changes at St. Stephen four of the five living children of Mr. and Mrs. Boardman had gone to Minneapolis and they were naturally anxious that their parents should make their home in that city. Mrs. Boardman was also desirous of living there as Mr. J. Clark Taylor, the husband of her only daughter, was in business in that city and it was very natural that Mrs. Boardman wished to be near her.

Consequently, in 1881, Mr. Boardnian sold his house and real estate in St. Stephen to the treasurer of the St. Stephen cotton mill company and spent the winter in Palatka, Florida, at the home of his son. The next spring they returned to Calais for a short time and then went to Minneapolis for a year, living with Mrs. Taylor. While in Minneapolis, although Mr. Boardman did not intend to make it his future home, he purchased the fine lot facing on Oak Grove street in that city, ruming through to Fifteenth street which was the line of Central Park, now called Loring Park, which was about the choicest lot in Minneapolis at that time.

On June 2, 1883, Mr. and Mrs. Boardman left the west on their return to Calais where they spent the summer, but in the autumn of that year they again went to Florida for the winter. In the spring of 1884 
they returned to Calais and took possession of the house on Lafayette street in that city where Mr. Boardman later made his home. He had built this house in the year 1869 for his son, Charles A., before he went west to spend a few years with his children. The years between this period and the death of Mrs. Boardman were spent at home and in visits to the sonth and to Washingtonthe summers at the north and the winters in a more genial climate.

In 1886 they went west; the years 1887-188s were passed entirely at home with the exception of brief visits to Boston, New York and VVashington. The winters of 1889 and 1890 were again spent in Florida, the last for much of the time in company with Dr. and Mrs. Foster of New York. The winter of 1891 was the last which Mr. Boardman and his wife spent at the south. In that summer Gov. Burleigh and his staff on an official visit to Calais passed a day with the Boardmans and in leaving Mr. Boardman accompanied the party to Eastport. In the fall of that year Mr. and Mrs. Boardman spent three months at Clifton Springs, N. Y., where Mrs. Boardman received much benefit to her health from treatment at the Foster sanatorium at that place. In 1892 they again spent the summer at Clifton Springs and in the west. The year 1893 was passed at Calais and on March 4, 1894, the death of Mrs. Boardman occurred in the house on Lafayette street, their summer home for the ten years previous.

The family of George Augustus and Mary Jane Boardman consisted of eleven children, viz.: Charles Augustus, born December 24, 1844 ; married Mercie F. Doane, October 20, 1868, who died March 28, 1891. 
Georgiana A., born August 8, 1846 ; married J. Clark Taylor, October 20, 1869. Frederic Henry, born April 25, 1848 ; married Hattie Curtis Boutelle, June 8, 1870. George Toppan, born January 8, 1850, died June 28, 1859. Albert J, born February 6, 1852; married Sarah Louise Toogood, September 6, 1876. Frank Edwin, born September 14, 1860, died Norember 16, 1861. William B., born March 1, 1862 ; married Jessie Prescott Wilbur, September 1, 1887. Lewis Hayden, born July 29, 1863, died March 22, 1865. Three sons died in infancy. The living children of Mr. Boardman are: Charles A. Boardman, United States Consul, Rimouski, Quebec, Canada ; Mrs, J. Clark Taylor, Calais, Maine; Fred H. Boardman, County Attorney, Minneapolis, Minn.; Albert J. Boardman, with United Gas and Improvement Company, Philadelphia, Pa.; William B. Boardman, Real Estate and Insurance, Minneapolis, Minn.

If the record of Mr. Boardman's life between the years 1869 and 1887, as given in the preceding pages, appears brief, it must be remembered that this was the period of his greatest activity and prominence as a naturalist, the erents of which belong in a chapter by themselves. They are so disassociated from his bisiness career and stand out in such prominence in his life as a distinguished ornithologist and the friend of the most eminent scientific men of his time, as to merit a more minute record than is given to his mere business activity. In saying this it is not forgotten that it was success in business due to his splendid abilities, industry and sterling character, which enabled him in comparatively early life to relinquish business for the charms and pleasures of nature-study in which he won such eminence. 


\section{CIIAPTER IV}

\section{LIFE RECORD OF A NATURALIST}

\section{I}

a paper written for the Maine Ornithological Union and which was read at its meeting held January 27 , 1898, Mr. Boardman gives an entertaining account of the incidents which led to his becoming a naturalist, in which he answers the question often asked, "What gave him so great an interest in the study of birds while in the management of a large business." His reply in brief was that he believed every business man should have some farorite pursuit or hobby. "I think young people,' he says, "should study natural history - inculcate in the minds of the boys and girls a regard for the beautiful in nature, whether of flower, insect, fish or bird; awaken an interest in such studies as botany or ornithology. How often we meet those with idle brains who do not know how to kill time. Such investigations would be a great stimulus." He then relates that in December, 1840, he made a business trip to the South American coast and the West India islands. The firm of which he had been a partner but two years was largely engaged in sending lumber to those parts and it was thought best that Mr. Boardman should go there, 


\section{THE NATURALIST OF THE ST. CROIX}

see the customers of the firm and spend the winter. He was then but twenty-three years of age and was a young man to be sent upon such a business mission. How well his evenings and odd moments during the day, when not at work, must have been spent in reading and useful studies, to have given this young man of twenty-three such mastery of his business that the older members of the firm could feel satisfied to send him on an important business trip to those foreign ports!

Mr. Boardman landed at Berbice in British Guiana in January, 1841 - a place only six degrees from the equator. He seemed to have been transported to a new world. Everything was novel, strange and delightful; the flowers, the trees, the fruits and foliage, the birds, animals and people were all new and interesting. He was captivated by the beauty of the birds in their gorgeous plumage; while the rich flora, the orchids and the grandest of all the lilies, the Victoria regia, the leaves of which were six and a half feet in diameter, which he saw growing in its native habitat, the Berbice river - all these gave unbounded delight. From Berbice Mr. Boardman went to Demerara, one hundred miles north of Berbice, where the firm had sold large quantities of lumber; and from there to Barbados, then to St. Vincent, Guiana, Trinidad and the Windward Islands, in all of which places the firm had customers and in each of which he saw beautiful birds, interesting plants and strange animals.

At Demerara, Mr. Boardman had letters to a gentleman having a large estate in the country, whom he found to be a good naturalist. Mr. Boardman enjoyed his acquaintance very much. He told him about the birds, 
trees, flowers and animals of the island; and sent his men with him in boats up the rivers of the forest where he saw "flocks of noisy parrots, scarlet and white ibis and heard the harsh scream of a bird called a horned screamer." These all produced in Mr. Boardman's mind such a love for birds and natural objects that he returned from his trip imbued with a new love of nature and determined to study and know something of our own birds and our own natural history, of which, up to that time, he had possessed only the knowledge of any intelligent country boy. "For a naturalist it was a wonderful land under luminous skies, where summer and bloom last all the year" -were Mr. Boardman's words in concluding his paper. He believed, however, that there were many birds, plants, trees and animals in Maine about which it was every one's duty to know something and he resolved to spend some portion of each clay in their study. Wliat an authority in Maine ornithology he became and what knowledge he afterward acquired of the fauna of the St. Croix valley, the lists which he gave to science abundantly testify. It may be added here that Mr. Boardman's firm sent much lumber to the port of St. Pierre, Martinique, which entered into the construction of the buildings destroyed by the volcanic eruption of May 8-9, 1902.

Mrs. Taylor, Mr. Boardman's daughter, relates an interesting instance of how, when a very small girl-she was born in 1846-with her younger brother, she watched the movements of some birds for her father. A pair of yellow warblers had nested in a tree quite close to the house - the first cottage in which the family lived - and in a gale the wind had nearly torn the nest away, tip- 


\section{THE NATURALIST OF THE ST. CROIX}

ping it almost bottom side up. The birds at once began to make repairs upon their home and Mr. Boardman set the little children at watching them. The branch of the tree on which the nest was fixed was quite near a chamber window and the children were stationed in the room to watch the progress and report. The birds rebuilt the nest and when it was occupied and the birds were engaged in hatching the eggs Mrs. Taylor remembers that they had a small clock in the room and were to note how long one bird would sit upon the nest before being relieved by its mate. The children were delighted to be a help to their father in this way and came, through such interesting incidents, to love to watch and study birds themselves.

In the first letter which Mr. Boardman wrote to liis correspondent, Dr. William Wood of East Windsor Hill, Conn., dated September 23, 1864 and referred to in that chapter of this volume which gives a resume of this interesting correspondence at some length, Mr. Boardman says: "Mr. Allen is mistaken in thinking me an ornithologist or oologist, as I do not pretend to be either. A person can have a love for flowers and not be a botanist, or have a love for birds and to observe their habits without being an ornithologist or oologist." It appears that Mr. J. A. Allen, then of Springfield, Mass., had mentioned Mr. Boardman to Dr. Wood and the latter gentleman had at once written to him, saying: "I trust that I need make no apology for addressing one engaged in the same pursuit as myself - in fact, I find naturalists, every where, belong to one brotherhood." This had brought out Mr. Boardman's most interesting letter from which the above extract has been given and 
thus began a most delightful correspondence which extended over a period of more than twenty years.

In one of the earliest letters from Mr. Boardman to Prof. Spencer F. Baird of the Smithsonian Institution, which has been examined, dated January 4, 1865, Mr. Boardman writes: "I have long been a close observer of the habits of many common birds in their northern distribution and for some time have been a collector of birds." In this same letter he says: "There has been considerable written about the Cliff Swallow migrating south. I came from Massachusetts to this part of the country in the year 1828. The Cliff Swallow was then very abundant, building the whole length of the eaves of barns, as much we see them now, which was not the case in Massachusetts." As Mr. Boardman was only ten years of age when he came to Milltown from Newburyport in 1828, his knowledge of the habits of birds, which this last extract from his letter shows he possessed as well as his observation of their habits, must have commenced at an earlier date than his correspondence or writings would show. But during the earlier years of his life his devotion to business was most intense. Nothing was allowed to interfere with his close application to the interests of his employers and of his firm. This was, however, no evidence that in his earlier years he did not love natural history. The passion for nature studies was only latent during his early business life. It was to be developed and enjoyed in after years when business success had made possible leisure and means for its fullest appreciation. All recollectious of his conversation about beginning the study of birds, however, as well as his own statements in the 
paper quoted at the opening of this chapter, show that it was his interest in the beautiful birds of the tropical islands which he visited in 1841 that led to his determination to study and know the birds of his own locality.

Mr. Boardman commenced keeping a private diary in 1853, the first entry having been made on February 14 of that year. Some of the earliest records relate to natural observations. He notes the first plum and apple blossoms ; the first dahlias in bloom; while on August 20 he "went up the road gunning." On April 13, 1854, the record notes: "Saw robin this morning." On May 22 he "saw the first blue violets." August 10 he records that he "went gunning up the road and got nothing;" but on August 25 had better luck as he went fishing and caught trout, also shot eight partridges. Entries similar to the above appear throughout the fall months. He went shooting and fishing every week, frequently for days in succession and the entries show that he shot four, eleven and fifteen partridges on successive times out. But few entries in his diary for the year 1855 relate to birds. He records the first robin April 10, the first martin April 26 and the first swallow May 2. During the autumn he went gunning and fishing sports which he afterward followed all his life-often; frequently two or three times a week.

On October 7, 1857, Mr. Boardman was, as he expresses it, " hung up" with a cold. He could not, however, be idle, it was so foreign to his nature and habits, so he "set up" a wood duck - the first entry in his diary which relates to taxidermy and it may be said that his magnificent collection of birds dates from that period. In September, 1858, Mr. Boardman was in Philadelphia 
and made his first visit to the Academy of Natural Sciences. Being in Boston in April, 1859, he purchased of T. M. Brewer a copy of Wilson's American Ornithology, from which undoubtedly he commenced his first systematic study of birds.

The year 1860 was one full of interest to Mr. Boardman. His diary notes the capture of his first Harlequin duck, February 7. The first robin appeared April 11, the first swallows April 20 and the first bobolinks May 25. In March of that year he went to Philadelphia and Washington. In the former city he met John Krider and examined his birds. At Washington he visited the Capitol, the Patent Office, the conservatory and the Smithsonian Institution. He spent the most of the time for three days at the Smithsonian and met Prof. Spencer F. Baird for the first time. In August Mr. Boardman was again in New York and saw the Prince of Wales land in that city on his visit to the United States. On September 22 lie "set up" an eagle and on December 7 mounted a grebe.

Down to that year Mr. Boardman had resided in the small cottage which he built the year of his marriage and where he began keeping house in December, 1843. But on September 5 he moved into the new house which he had built in 1860 at the corner of Main and Church streets. It was in a special room of this house that he had the large case of mounted birds, which is now in the Parliament House, Fredericton, N. B., forming as it does one of the main features of interest as it is an original design by Mr. Boardman. It is the case marked $\mathrm{A}$ in the plan of the room given in this volume. It consists of a tree which forms the centre of the case, the branches 


\section{THE NATURALIST OF THE S'T. CROIX}

of which are full of mounted song birds disposed in their most characteristic attitudes. While living in this house Mr. Boardman kept his collection of mounted birds in the parlor until the building of the bird house in 1863 .

In November, 1861, Mr. Boardman attended a meeting of Naturalists at Cambridge Mass., where he met A. E. Verrill, Prof. Shaler, Alpheus Hyatt and D. G. Elliot.

From Mr. Boardman's diary and correspondence it is evident that the year 1862 was a most active and interesting one in his studies, his collecting and his visits to naturalists. He was at the height of his great business enterprises and made frequent trips to Boston, New York and Philadelphia in the interests of his firm. But he was also making these visits opportunities to meet naturalists, visit the museums and attend meetings of scientific societies. In that year no less than twentysix entries relating to birds are found in his diary. They extend from April 9 to December 16. He notes in that year robins, swallows, snowbirds, shelldrakes, grebes, bluejays, eagles, martins, fishhawk, ducks, warblers, gulls, sea parrots, herons, yellow birds, sandpipers, grosbeaks, partridges, white owl, sea dove and banded woodpecker. On July 16 he skinned a Northern Phalarope and a Sea Parrot.

During the last of March and first of April Mr. Boardnuan went to Philadelphia and Washington. At Philadelphia he went to the rooms and meeting of the Academy of natural sciences. In Washington he spent several days at the Smithsonian Institution, visited the Botanic Garden of W. R. Smith, and called upon Senator Hamlin and Hon. Fred'k A. Pike, representative to Congress from Calais. At Philadelphia he always called 
on John Krider and in New York on D. G. Elliot. In Boston, in October, he attended a meeting of the Natural History Society. It was in that year that Mr. Boardman began correspondence with many eminent naturalists, among them D. G. Elliot, A. E. Verrill, Dr. T. M. Brewer, Elliot Coues, H. E. Dresser of London, Eng. and John Krider, a commercial bird-man who was a well-informed ornithologist with whom Mr. Boardman exchanged birds and eggs for many years. On May 14, 1862, Mr. H. E. Dresser, the eminent English ornithologist, visited $\mathrm{Mr}$. Boardman for the first time and remained some days.

In 1862 the results of Mr. Boardman's observations and studies in the ornithology of the St. Croix valley were first published to the scientific world. Previous to this he had for ten years been carrying on his studies of the fauna of his locality with ever increasing interest and yet with so much privacy that it was only within a few years prior to 1862 that naturalists in other parts of the country had been aware of the extent and value of his notes. Entered upon wholly for his own enjoyment and as a pleasure and recreation from the cares of a large business, his observations in ornithology now attracted the attention of those engaged in similar studies who had acquired wide scientific reputation. Moreover, Mr. Boardman's correspondence with naturalists and his visits to the natural history societies of the various cities had brought him into prominence and accorded him welcome to their collections and their meetings.

A "Catalogue of the Birds found in the Vicinity of Calais, Maine, and about the Islands at the Mouth of the Bay of Fundy, by George A. Boardman,"' was published 


\section{THE NATURALIST OF THE ST. CROIX}

in the Proceedings of the Boston Society of Natural History for September, 1862, Volume IX, pages 122-132. This was published with the following introductory note from A. E. Verrill: "The following list of birds was originally sent to me by Mr. Boardman for my own use and was not intended for publication; but, finding that it was very complete and valuable for determining the geographical distribution of species, I requested him to publish it. This he could not attend to himself and I have, with his consent, re-written it in a systematic form, adding, in some cases, observations made by myself at Grand Manan in 1859." This note of Prof. Verrill shows plainly that Mr. Boardman was so closely engaged in business that he could not attend to the publication of the list, while Prof. Verrill gives it the just compliment of saying that it is "very complete and valuable." The list enumerates two hundred and twenty-five species. Regarding the Tufted Puffin, Prof. Verrill says: "Mr. Boardman states that the fishermen say that a Tufted Puffin, or Sea Parrot, is occasionally seen about the islands in winter. This species is also said by Audubon to be sometimes found on the coast of Maine. A specimen in the Museum of Comparative Zoology was probably obtained at Grand Manan."

A copy of this list had also been sent to Prof. Spencer F. Baird of the Smithsonian Institution, who, in acknowledging the same, wrote in a letter of December 2, 1862: "I duly received your interesting catalogue of Calais birds ; it makes a fine show of species."

On page 233 of Volume IX. of the Proceedings of the Boston Society is an additional list of twelve species of Maine birds described by Mr. Boardma11. Of the 
Prothonotary Warbler Prof. Verrill says it was unknown in New England until Mr. Boardman obtained it - a single tmale specimen, "slot the last day of October on a tree in the edge of a swamp." The Banded Threetoed Woodpecker found during a severe winter was recorded as a rare winter visitor. Mr. Boardman found the Magnolia Warbler breeding in the season of 1862 .

More records regarding Mr. Boardman's studies upon birds appear in his diary througliout the year 1863 than in any year during which it was kept. He not only made collections of birds but of eggs and nests. Boxes of birds and eggs were sent to his naturalist friends and also received from them in excliange. Sixty-four entries relate to individual birds, to his collection and to his work among birds like the following: Skinning and mounting birds; getting nests and eggs, sending off and receiving specimens and marking bird skins. In March Mr. Boardman visited Fredericton, went to the Parliament building, library and university. He also went to New York and Boston in that month. In the latter place he attended a meeting of the Natural History Society and in Cambridge visited the Museum of Comparative Zoology. Again in October he attended a meeting of the Natural History Society in Boston.

Mr. Boardman's collection had during the past three or four years been increasing very rapidly. He had made large additions to it by his own collecting and by his extensive exchanges, while he had also had for several years men in the woods, at Grand Manan and other places along the river and bay who were constantly sending him specimens both common and rare - for he wanted both, either for his own collection or for 


\section{THE NATURALIST OF THE ST. CROIX}

exchanges with his large list of scientific correspondents. His collection had in fact outgrown the rooms of his dwelling assigned to it and in the fall of 1863 he built a special building into which his birds were moved from his house on September 14 of that year. This building was sixteen by twenty-six feet and ten feet posted, very pretty in its Swiss style of architecture and being surrounded by trees and shrubbery formed an attractive feature of the grounds. When lis birds were installed in this house Mr. Boardman took great pleasure in being in it, arranging his collections and working among his birds, nests and eggs.

In June, 1864, John Krider, the Philadelphia naturalist and commercial bird-man, first visited Mr. Boardman and remained two weeks. They went to the Grand Lakes, to Maguerrawock and numerous other places of local note for birds, obtained many rare specimens and had a fine time together on shooting and collecting trips. A correspondence, exchange of specimens and friendship existed between them throughout life. On his business visits to New York, Pliladelphia, Baltimore, Providence and Boston, which were very frequent, Mr. Boardman always called on his naturalist friends and no entries in his diary are made with more regularity than those in which he records his visits to them and that he looked over their collections. He was always intent on new or rare things and was glad to see what his friends possessed or had obtained since previous visits.

In this year Mr. Boardman received from the Smithsonian Institution a series of bird skins from the most northern portion of the continent of America, collected by the collaborators of the Institution in the Hudson's 
Bay Company. In transmitting them to Mr. Boardman, Prof. Joseph Henry, then secretary of the Smithsonian, said in his letter of June 17, 1864: "They embrace skins of some of the rarest of American birds and we have thought proper, in accordance with our general policy, to make a distribution of the duplicates to such museums as would be most likely to value and make good use of them." It was a distinguished consideration on the part of officials of the Smithsonian to place these duplicates of rare specimens in a private rather than a public musemm, and was a recognition of Mr. Boardman's standing as a naturalist as well as a partial return for his services to the Smithsonian Institution. It was an honor, too, which Mr. Boardman highly appreciated. His studies of this collection of skins and his subsequent studies at the Smithsonian gave Mr. Boardman that knowledge of arctic ornithology which placed him in the front rank among naturalists faniliar with arctic bird-life.

Mr. Boardnuan had met Prof. Baird at Washington in the early spring of 1860 and also in 1862 . In a letter to Mr. Boardma11, dated November 19, 1862, Prof. Baird commences it by saying: "I look forward with much pleasure one day to meeting you way up in New Bru11swick ; when - I dare not say." This pleasure was not realized, however, until nearly three years later. During the year 1865 Prof. Baird and his family spent the summer at Eastport, Maine-which was their summer home for many years afterward - and on August 10 he visited Mr. Boardman at St. Steplen, N. B., for the first time. It must have been a very happy meeting as it was the commencement of a close and intimate friendship 


\section{THE NATURALIST OF THE ST. CROIX}

between the two naturalists which was only terminated by Prof. Baird's death. It was also doubly happy to Mr. Boardman, for at that time he was enjoying a second visit from Henry E. Dresser, the eminent English ornithologist and his brother Joseph - who is always referred to in Mr. Dresser's letters to Mr. Boardman as Joe. The Dressers reached St. Stephen on August 7 and left on the day following Prof. Baird's arrival and the meeting of these famous naturalists must have been an event of great pleasure to each of them. After spending a day or two at St. Stephen, Prof. Baird went to Eastport but returned again with Mrs. Baird and his daughter Lucy. While their guests Mr. Boardman took Prof. Baird to the Grand Lakes and other interesting places for birds and fish and after a stay of some days Prof. Baird returned to Eastport, leaving Mrs. and Miss Baird with the Boardmans. This was also the beginning of a long friendship between the two families and many were the visits made to and from each in after years. On their return to Washington in September Mr. Boardman accompanied the Bairds to Boston and New York where the two friends "went around to see all the scientific folks" - as Mr. Boardman records in his diary.

The years 1866 and 1867 were extremely busy years with Mr. Boardinan so far as his business interests were concerned. During these years he went many times to Boston, Providence, Baltimore, New York, Philadelphia and Washington on business for his firm - selling cargoes of lumber, calling upon business friends, making collections and purchasing supplies for his lumbering camps and mills. But the interests of lis dearest pursuit, 
his studies of bird-life, were never forgotten. Often it is difficult to understand if they were not indeed primary rather than secondary objects on many of these trips, for he always spent much time at the museums and in calling on his scientific friends. In Washington he invariably spent many days at the Smithsonian Institution; while in Philadelphia he always called on Mr. Krider, in New York on Mr. Elliot and visited the Central Park, while in Boston the rooms of the Natural History Society were always a charmed place for him and where le met many naturalists. He also visited places nearer home. His visits to Fredericton were frequent where he enjoyed the collection of Mr. Sill. His own collection of birds was also becoming better known and was visited by many prominent people. In April, 1866, his museum was visited by Admiral Sir James Hope, Governor Gordon, General Doil, Captain Holdness and other British officers. Several visits "to the west" - as Mr. Boardman then called his trips to places as far as Washington - were made in 1867. Four times at least he went to New York, spending from four days to a week at each visit.

His eldest son, Charles A., having been admitted to the business firm in 1867, Mr. Boardman relinquished much of its care to him and made his first visit to Florida in the winter 1867-68, leaving home on December 26, 1867. Several reasons led to his making this winter journey to Florida. Mr. Boardman had studied the birds of the St. Croix for many years, knew them all and wanted to know more about the birds of other parts of our own country. As has been stated in a previous chapter, the division of work with his firm was such that 


\section{THE NATURALIST OF THE ST. CROIX}

Mr. Boardman took his vacations in winter while his partner had his in the summer. Moreover, Florida was at that time coming into notice as a winter sporting and pleasure resort and Mr. Boardman having abundance of leisure decided to spend the winter at the soutl. It was a month after leaving home before he reached Jacksonville. He remained several days in Philadelphia and spent fonr days in Washington where he studied at the Smithsonian Institution. His stay in Florida that first winter was not long, as he reached Fernandina on January 30, 1868 and left for the north on March 16, 1868. He reached home April 22 and the first thing Mr. Boardman did after his arrival was to go "all round and see the folks." Then he records in his diary, April 30: "Dull and rainy. Went after Mayflowers; got only buds." Could there be any doubt of his genuine love of nature when this busy man of affairs, after a winter in the land of birds and flowers, on reaching his northern lome, would take a rainy day on which to go after Mayflowers?

On that first visit to Florida Mr. Boardman bore a letter addressed " 'To Correspondents of the Smithsonian Institution and the Friends of Science Generally, ' from Joseph Henry, then secretary of the Institution. It was in these words: "The bearer of this letter Mr. George A. Boardman visits the Sonthern States for the purpose of studying its Natural History and collecting specimens in part for the Sulthsonian Institntion, and I beg to commend him and his object to your kind consideration and assistance. Washington, D. C., January 18th, 1868." Provided with such an introduction $\mathrm{Mr}$. Boardninan liad exceptional advantages for making acquaintances and 
for special facilities being placed at his disposal to make explorations and obtain specimens.

There has been found anong Mr. Boardman's papers, in pencil - the paper on which it is written being much worn and stained - a list of birds with this endorsement : "Birds observed in Florida by G. A. Boardman, 1868-1869, wiuter."

This list embraces one hundred and seventy species and notes on their occurrence are attached to many of them. It has been compared with a list sent by Mr. Boardman to Mr. J. A. Allen, then of the Museum of Comparative Zoology, Cambridge, Mass., and is here printed exactly as given by Mr. Boardman. It is interesting as standing for just what it is - a field naturalist's list with no attempt at scientific nomenclature. His knowledge of bird-life and his close habits of observation are apparent throughout the list, which is a long one for a single observer to make in a locality in which he had not been previously acquainted and in the brief time stated.

'This list had been sent Mr. Allen in answer to his request for the same. Writing Mr. Boardman on October 23, 1869, Mr. Allen solicited his aid in making up notes on Florida birds for publication by saying: "As you have had much experience in Floridian ornithology I have no doubt you have many facts not known by me. If you do not propose to publish your observations yourself, would you be willing to communicate some of them to me for incorporation in my proposed paper?" Again on October 29, Mr. Allen in writing Mr. Boardman says: "I am sure you must have many notes on Florida birds that will be very valuable to me, especially on the water birds since you have had so good an opportunity 


\section{THE NATURALIST OF THE ST. CROIX}

to see them. I should be very much gratified to receive a summary of your observations with liberty to use them. I should of course give you the fullest credit therefor." In both letters Mr. Allen asks numerous questions upon which he wants information. The very day of the receipt of this last letter, Mr. Boardman sent his list and notes on Florida birds, accompanied by the followig letter :

\section{Friend Allen:}

Milltown, Maine, Oct. 29.

I send you today a list of birds from my notes and think I have taken them all off. I write them by the common name as I am troubled to spell the scientific names correctly. If I had time I wonld like to write you some observations about some of them but I find if I should begin, it would take too much time and you would not perhaps care for it. I wish something could be done to keep the visitors from shooting every bird they come across. 'The little Paroquet must soon be exterminated. Some of our Enterprise party would sometimes shoot forty to fifty at a few discharges for sport, as they hover about when any are shot until whole flocks are destroyed. 'The White Egrets and Snowy Herons are so persecuted that many of their breeding places are destroyed. Where I saw them quite abundant in 1868 , in 1869 they had all left; they shoot them by hundreds, for their plumes.

I have about made up my mind to go to Florida again this winter and shall probably leave in December.

I do not know as $I$ answered your question about the breeding of the Crossbills. They breed all the season from February 20 to May and perhaps later. 'The Canada Jay also breeds when the snow is quite deep in March and $I$ think breeds again in summer as I have seen young birds in September. I have also found ravens' eggs when the snow was quite deep. Have seen the young of Mergus Americanus out with young the middle of May, which is unusually early.

Yours very truly,

GEO. A. BOARDIIAN. 


\section{List of Florida Birds, 1868-1869}

Butterball; not very common.

Ruddy Duck; not uncommon, river and coast.

Hooded Merganser; very abundant on the coast.

White Pelican; seen in large flocks at mouth of St. Johns all winter.

Brown Pelican; abundant; Fernandina and mouth of St. Johns river.

Gaunet; very abundant on the coast in winter.

Booby Gannet; saw a few on the coast.

Florida Cormorant; very abundant on river and coast.

Water Turkey; very abundant on the river.

Wilson's Petrel; a few about the coast at Fernandina.

Hagdon's Great Shearwater; a few about the coast at Fernandiua.

Razorbill Shearwater, Skimmer; abuudant on coast; large flocks.

Herring Gull; abundant all winter.

Ring-billed Gull; not very plenty.

Laughing Gull; abuudant all wintel.

Bonaparte Gull; not very plenty.

Cayenne 'Tern; abundant about the coast.

One or two small terns about the coast.

Horned Grebe; not uncommon on the St. Johns river.

Pied-billed Dabchick; not uncommon on the St. Johns.

Great-White or Whooping Crane.

Wild Pigeon.

'Turkey Buzzard; very common, St. Johns river.

Black Vulture; quite rare about the St. Johns river.

Duck Hawk ; St. Augustine, February, 1868; one instance.

Pigeon Hawk; St. Augustine; frequent.

Sparrow Hawk; common.

Cooper's Hawk; common.

Sharp-shinned Ilawk; common.

Red-tailed IIawk; not common.

Red-shouldered Hawk; most common hawk except fish-hawk. Broad-winged Hawk; common. 


\section{THE NATURALIST OF THE ST. CROIX}

Swallow-tailed Hawk; saw none until February 20; rare in winter, I think.

Marsh Hawk; common about St. Augustine.

White-headed Eagle; very abundant.

Fish Ilawk; very abundant; most common hawk breeding in January.

Caracara Eagle; two specimens; only February and March; frequent at Enterprise.

Great Horned Owl; rare; one specimen at Enterprise in February.

Mottled Owl; not uncommon.

Short-eared Owl; common about marshes.

Barred Owl; very abundant.

Parrakeet; very abuudant, but will soon be destroyed if so many are shot.

Ivory-billed Woodpecker; quite rare ; saw but few pairs.

Hairy Woodpecker; rare.

lied-cockaded Wroodpecker; very abundant in pine woods.

Yellow-bellied Woodpecker; common.

Pileated Woodpecker; very abundant, small size.

Red-bellied Woodpecker; very abuudant.

Red-headed Woodpecker; rare.

Golden-winged Flicker; very abundant.

Ruby-throated Humming bird; first February 20; common in March.

Chimney Swallow; March.

Chuck-will's-widow; March.

Kingtisher; abundant all winter.

King-bird; first April.

Great-crested Flycatcher; tirst April.

Pewee; abundant all winter.

Wood Pewee; March; rare.

Least Flycatcher; rare; March.

Hermit Thrush; abundant all winter.

Wilson's 'Thrush; not common; Greencove Springs, February 20,22 .

Olive-backed 'Thrush (Swainson's); rare; one at Enterprise. February 18; one at St. Augustine, February. 
Robin; not abundant; keeps to the woods and is quite wild. Blue-birl; common and breeds, nesting last of February. Rilby-crowned Wren; common all winter.

'lit-Lark; abmulant all winter.

Black and White Creeper; rare; February 15, first.

Blue Yellow-backed Warbler; saw none in January; common in February.

Marylaud Tellow-throated Warbler; all winter, common.

Nashville Warbler; only one 13th Mareh at Jacksonville.

Orange-erowned Warbler; few 15th February, Enterprise, rare.

Yellow-rumped Wabler; very abundant all winter.

Pine-creeping Warbler: very abundaut all winter.

Black-ant-yellow Warbler; one specimen February 27 at Greencove Springs.

Yeliow Red-poll Warbler; abundant all winter.

Tellow-throated Warbler; common all winter.

White-bellied Swallow; abundant all winter; flocks of thousands.

Bank Swallow; first April.

Rough-winged Swallow; first A pril.

Purple Martin; come to boxes 15th Feloruary; think resident.

Cedar-bird ; abundant all winter.

Loggerhead Shrike; abundant all winter.

Red-eyed Vireo; rare; Enterprise, a few all winter.

White-eyed Vireo; rare; one specimen in February.

Mlocking-bird; abundant; breeds in Mareh.

Cat-bird; abundant; winter resident.

Brown 'Tlurush; abundant all winter.

Great Carolina Wren; March 20, at Jacksonville.

Prairie Warbler; common the last of February.

House Wren; not uncommon.

Winter Wren; January and February; rare.

Short-billed Marsh Wren; rare; last of February at Enterprise.

Brown-headed Nuthateh; rery common all winter.

Blue Gray Flyeatcher; abundant all winter.

Crested Chickadee; common in February.

Carolina Chickadee; rare; Greeneove Springs.

Thistle-bird - Yellow-bind; common all winter.

Savanua Sparrow; common all winter. 


\section{THE NATURALIS'T OF THE ST. CROIX}

Bay-twinged Bunting; common all winter.

Sharp-tailed Finch; common.

Seaside Finch; common.

White-throated Sparrow; common all winter.

Black Snow-bird; common in January.

Field sparrow; common all winter.

Chipping Sparrow; common all winter.

Song Sparrow; common all winter.

Swamp Sparrow; common all winter.

Bachman's Finch; not uncommon.

Fox-colored Sparrow; rare; two instances only.

Painted Bunting; April I.

Ground Robin; very abundant all winter; two varieties.

Red-winged Blackbird; very abundant all winter.

Meadow Lark; very abundant all winter.

Rusty Blackbird; rare; saw a few scattering small flocks.

Boat-tailed Grackle; very abundant all winter.

Crow Blackbird; very abundant all winter.

Crow; abundant all winter.

Fish Crow: abundant all winter.

Blue Jay; abundant all winter.

Florida Jay; very local ; ouly found about Enterprise; common.

Common Dove; abundant all winter.

Ground Dove; abundant about St. Augustine.

Wild 'Turkey; common at Enterprise.

Quail; common; the bill appears a little larger but the bird smaller than at the north.

Sand-hill Crane; quite common.

Limpkin Crying-bird; not uncommon; Lake Dexter; Lake Henry.

White Heron, or Egret: very abundant.

Small White Heron, or Egret; very abundant.

Great Blue Heron; very abundant.

Blue Heron; very abundant.

Louisiana Heron; rare.

Bittern or Stake Driver; rare.

Green Heron; not rare.

Night Heron; not rare. 
Wood Ibis; plenty.

White Ibis; plenty.

lioseate Spoonbill; rare on St. Johns, more uncommon on Indiau River.

Killdee Plover; very common all winter.

Wilson's Plover; all winter, st. Augustine.

Ring Plover; all winter common, St. Augustine.

Golden Plover; rare, St. Augustine.

P'iping Plover; all winter, St. Augustine.

Black-necked Stilt; common last IIarch, Enterprise.

Woodeock; January and February; not rare.

English Snipe; abundant all winter,

Oyster-cateher; rare; St. Augustine in winter.

Turnstone; St. Augustine, rare.

'Telltale Tattler ; common St. Augustine aud St. Johns.

Sanderling; St. Angustine; common all winter.

Willet; St. Augustine; common all winter.

Great Marbled Godwit; St. Augustine; common all winter.

Spotted Sandpiper; St. Augustine; common all winter.

Red-backed Sandpiper; St. Angustine; common all winter.

Long-billed Curlew; very abundant on the coast.

Marsh Hen; not uncommon on St. Johns river.

Clapper Rail; common on St. Joluns river.

Virginia Rail; common all winter, St. Johns river.

Common Rail; saw none until March 25, St. Johns River.

Yellow Rail; all winter, St. Johus.

Coot; very abundant.

Florida Gallinule; abundant.

Mallard Duck; common all winter in very large flocks.

Pintail Duck; not very common about St. Johus river.

Green-winged Teal; common all winter.

Blue-winged 'Teal; common all winter.

Shoveller; common all winter.

Baldpate; common all winter.

Wood Duck; abundant; breeds in February and March.

Big Black Head; not very common.

Little Black Head; most abundant duck on St. Johns river.

Red-head Duck; very rare; only a few seen. 


\section{THE NATURALIST OF THE ST. CROIX}

Canvas-back Duck; conmon.

Golden-eyed Duck; rare on coast.

Surf Duck; rare; only one specimen; (sea const).

White-winged Coot Duck; very rare on the coast.

Buffle-head Duck; not uncommon river and coast.

On receiving this letter and list of birds from $\mathrm{Mr}$. Boardman, Mr. Allen acknowledged them as follows :

Friend Boardian:

Cambridge, Mass., Oct. 31, 1869.

Yours of the 29th is at hand, together with your list of Florida birds, for which I am extremely obliged. It adds quite a number of species to my list which I should not otherwise have had, and valuable notes on others, all of which I shall be happy to use with due acknowledgements. In addition, if I may trouble you so much, I should like to know at what points you made most of your observations and duriug what months. I should like furtler particulars in reference to the wholesale destruction of certain species by hunters, especially of the Egrets, and at what points they have been most persecuted. On the whole oux notes rarely differ in respect to the abundance and time of occmrence of these species we both observed. In respect to the Vireos, however, I did not meet with the Red-eyed till March, while the White-eyed was common all winter - the reverse of what you state. The great Carolina Wren I found more or less common all winter. You mention both the Sharp-tailed and Seaside Finches? What were their pecu liar haunts? 'The coast? As already remarked in a previous letter, any facts in respect to the weight and general appearance of the Wild 'Turkey are solicited. Very truly yours,

$$
\text { J. A. ALLEN. }
$$

In further explanation of the places where Mr. Boardman collected, with additional notes, he writes Mr. Allen:

Multown, Maine, Nov. 3, 1869.

Friend Allen :

I have yours of October 31. I made all of my observation about East Florida, Jamuary, February and Mareh, with a week or two in April. Fernandina I found a very good place for shore and 
beach birds, also for Sharp-tailed and other finches. I was several times at the mouth of St. Johns river. I had some friends in Government employ who had nothing to do but to sail about, shooting. It was a very time place for water birds, Warlers, Egrets, Pelicans, Gannets, Skimmers, Osster Catchers., etc., etc. I also spent considerable time about St. Augustine, here saw more Curlews, Godwits, Plovers, Terns and many Waders - they were about the bars by the thousand, large White and Blue Herons were abundant. I got eight large White and three Blue in one evening. The ladies wanted the plumes. You find the roosting places by observing the way the birds fly at night or morning; conceal yourself about the trees and sloot the birds as fast as they come along; they come singly or nearly so and you can shoot any number, or go to the breeding places. One man bought a little schooner at Stevens where I boarded last spring to go down Indiam river, for nothing, only to shoot the Egrets and Herons, for plumes, to send to Europe and the states, and says it is a capital business. The Paroruets have a way of lovering about, when one or two are shot, and the more thit are wounded and shot, the more anxious they are to alight about them, and when in large flocks most erery bird cau be shot. Up at Enterprise last winter, they would shoot whole flocks only for the sport of seeing how many they could shoot at a shot, and unless something can be done, and I do not know what, they will be exterminated.

'The breeding places at Lake Dexter, Lake Jessup, were entirely broken up as were others up at Salt Lake, by plume hunters, last spring. About half our living up at Enterprise was wild turkeys; I used both winters to weigh many of them. There was a very great difference between the cocks and hens, six to ten pounds was about the weight of hens; cocks about twice as much, and often had them twenty-five to twenty-eight pounds bnt they were very fat. I saw one shot within one-half a mile of the Ferry house opposite Jacksonville a few days before I left there. I find many of the Florida birds are very local. I would see birds at Fermandina not to be seen about Jacksonville; at Jacksonville not to be found at Greencove Springs, and so on. Hardly a pleasant day I was not out to look and see if I could find anything new. 
Do you make any note of the animals and reptiles? I just received a paper from Robert Ridgway about Thrush, ete. Have you seen it? He makes two kinds of Purple Grackle; he is quite a nice observer and scientific fellow. I should be pleased to see your paper upon the rarer birds of Massachusetts. Some of your lare birds are quite common here. Did you ever know the Purple Galiunle in New England before I seemed one last summer? I have also found the Blue Grosbeak, Prothomotary Warbler, and I believe I wrote you the Tennessee Warbler was quite a common warbler; it breeds upon the ground. Many of your most common birds are never found here or very rarely. Chewink and Brown Thrush I neverfound; Bluebird, Oriole, Field Sparrow very rare, etc., ete. As ever yours,

GEO. A. BoARDMAN.

In the summer of $1869 \mathrm{Mr}$. Boardman visited Boston, New York, Philadelphia and Washington several times and in September of that year Prof. Baird visited him at St. Stephen, remaining ten days. On this visit the tro went to Oak Bay, Lewy's Island, St. Andrews and other places to dig for Indian relics in the collection of which Prof. Baird was greatly interested.

As interesting to science, mention is here made of the great Saxby gale which visited the coast of Eastern Maine and New Brunswick in the autumn of 1869. It took place on the late afternoon and evening of October 4 of that year, taking its name from Lieut. S. M. Saxby of the royal navy of Great Britain, who had predicted its occurrence and it took place on the exact date which Lieut. Saxby had set for its coming. It was a cyclone and accompanying tidal wave. It struck the coast of Maine at Eastport, doing great damage at that place and at Calais, while at St. Stephen, Fredericton, St. John and Sackville, N. B., it caused great damage to the coast and did havoc in the forests of the interior. In his 
diary for 1869 , he records: "October 4, Saxby gale." From this it appears that Mr. Boardman had read of its prediction in the English newspapers which he received, as Lieut. Saxby had predicted its occurrence ten months before it took place.

Sidney Perley of Salem, Mass., who published in 1891 a volume on the Historic Storms of New England, embracing those from 1635 to 1890 , gives a chapter to The Gale of September 8, 1869 but does not allude to the Saxby gale - a storm the like of which never occurred in the section of country which it visited, for severity and destruction.

Writing to Prof. Baird on October 14, 1869, Mr. Boardman says: "Nothing like it ever took place here. It appeared like a whirlwind. It took the roof off my long woodshed, my old store and part of the roof from the barn on the hill. The Universalist church was a perfect wreck; the railroad bridge over the falls in front of my house fell into the river; also the covered bridge at Baring. More than one hundred buildings in St. Stephen were ruined, and in our cemetery more than one thousand trees were uprooted and broken. At Eastport about forty buildings were destroyed or unroofed, several lives lost and most all the fishing crafts were wrecked. At Eastport and St. Andrews and about the islands the tide was very high and damaged the wharves much. Sixty-seven vessels were ashore-those that went on to soft places came off, many went on to the rocks and were ruined. The blow did not last but about an hour and was heaviest at eight o'clock in the evening. There was very little wind at Bangor and not much at St. John." In a letter to Prof. Baird of October 29, 1869, 


\section{THE NATURALIST OF THE ST. CROIX}

Mr. Boardman writes: "The great loss to this country from the Saxby gale will be to the woods. We have had some of our men up exploring and they say they can walk ten miles at a time on the trees that are down without stepping on the ground. In some places for half a mile about every tree is down. The bridges and buildings can easily be put back, but the woods all down will soon get on fire and burn all over the down district. The wind did not reach very far up the river, only about thirty or forty miles - it was the heaviest about the shores." The Saxby gale has gone into history as one of the most destructire gales that ever visited the coast of this state and of New Brunswick.

The years of 1869 to 1872 were very happy ones to Mr. Boardman. They were indeed among the happiest of his most happy life. The summers were spent at home and in visits to the great cities where he loved to go to meet his scientific friends and study at the museums, while the winters were spent in Florida. On January 7, 1869, he left for Filorida, accompanied by Mrs. Boardman and his son William. They made stops of several days at Boston and New York where Mr. Boardman met his old friends and made many new acquaintances. In Washington, at a party at Prof. Baird's, he met Hon. George F. Edmunds, United States Senator from Vermont, Judge Hale, Mr. King and others. At the Snithsonian Institution where he spent five days he met for the first time Robert Ridgway, Henry Banister, W. H. Dall, Prof. Gibb and other young naturalists. Townend Glover, Prof. Blake and Theodore Gill were also among those whose acquaintance he made at that time. Mr. and Mrs. Boardnian arrived at Jacksonville, January 25 and left on the return north, April 6 . 
Mr. Boardman wrote most interesting letters to Prof. Baird during his winters in Florida. In a letter of March 14, 1869, he says: "Florida of all places in the United States is most abundantly supplied with all kinds of game. There is more of animal life about Florida than in any place with which I am acquainted." Writing of the immense mounds and shell heaps he says: "You will have to come down and see for yourself. You can get a couple of weeks' vacation, come to Jacksonville, call for me and we can soon look over them. I want your opinion. I don't believe in Wyman, only Baird." In a letter written April 5, of this year, in which he described a box of skins he had sent to Prof. Baird, occurs this: "One poor little specimen of a warbler in the box I did not know; he looked very like a Tennessee Warbler but I was not sure." Here is reference to a young naturalist who afterward became prominent. He is writing to Prof. Baird, April 1, 1869: "I saw Mr. Maynard of Massachusetts down collecting. Said he had found a new Chewink or Ground Robin - took fifty specimens, male, female and young, all with white eyes, smaller size, outer tail feathers not white. I did not see them as he had sent them north. He says he got a White Heron not described. He collected at Indian River." A single letter from Mr. Boardman to Prof. Baird is a good specimen of the many letters he sent to his correspondents while at the South :

\section{DEAR BAIRD:}

ENterprise, Feb. 28, 1869.

I received your letter some time since and for the most of the time have been running abont, and have not had a very good chance to write, but have had a very good time boating, fishing, shooting, etc., etc. 


\section{THE NA'TURALIS'T OF THE ST. CROIY}

We usually leave here in a small boat after breakfast, take dinner with us, and go off, up or down the river for the day, and since I have been in Florida have only had one-half day rainy weather to keep me in the house; there has been a rainy night or two. 'The weather is splendid. Orange blossoms just going off the trees. I will give you our yesterday's boat cruise which will be something like most every day only we often get different game. Testerday we shot two Alligators, two Widgeons, Blue Wingteal, Puddy Dnck, Blackhead, six Qnails, White Egret, White Ibis and a fish basket full of Yellow Legs, Killdee, Snipe, Woodpeckers and small fry generally with half a dozen Paroquets. While spealing of the latter bird I think it must soon be almost exterminated. Everybody coming to Florida brings from one to three guns and they shoot every bird that comes within range and this bird when one is shot retmrns again and again, until almost every bird is shot down. One of om boarders last week shot forty in a few moments and knew nine shot at one discharge Friday. It is murder to destroy so pretty a bird for sport as they can do nothing with them. Yon know I told you last spring of flocks of birds with white bodies and dark wings. When flying they show a pme white body and dark wings. I find they are an Ibis, probably the White Ibis in immature plumage. We shot one yesterday and I have had several: they go in large flocks, most all in the dark wing plumage. I hare made a couple of skins of this plumage as I don't remember seeing one in your case.

I found Allen last week. He and two men are camping about seven miles below here; have been collecting all the way up the river and intend to remain where they are for ten days. They did not expect to go up any further, but I told them of a very interesting island in Lake Jessup where birds breed in large numbers, Egrets, Cranes, Herons, etc. I went up a couple of weelss ago and some expect to go again before I leave. Allen's party have about two hundred skins, nothing very lare. They have three Ivorybills and one Florida Jay. Mrs. B. and Willie returned to Jacksonville Weduesday. I shall probably be here another week, then go down river. I have made quite a good lot of skins for you here that will please you. The ladies at the house 
are crazy for birds, wings, etc. 'This is a large hotel, accommodates about one hundred and as nice a set as you find at any of the northern watering places. Half my time is taken up with mounting and fixing wings. We have no rainy or stormy days so have to go shooting days and work nights. Old Indian mounds and shell heaps in every direction often ten to fifteen feet deep. Come down and dig. With kind legards to Mrs. Baird and Lucy, I am as ever,

Yours,

$$
\text { G. A. Boalinitan. }
$$

Mr. Boardman had been very much interested in the effort which the Smithsonian officials had been making for a Congressional appropriation for a new building. Prof. Baird was foremost in this work before the committee and on March 7, 1869, Mr. Boardman writes him to congratulate him upon "getting your appropriation for the new musetum. I thought at one time you would hardly get it through. Fortune always favors the brave. I thought all winter it was a nean Congress, but I like the members better now."

In August and September of that year Prof. Baird and family spent several weeks with Mr. and Mrs. Boardman and together they visited the most attractive places for outdoor excursions about St. Stephen and Calais. This visit of the Bairds was most enjoyable to all. Mr. Boardman and his wife were delightful hosts, were constant in their attentions to guests and did everything possible to make their visits occasions of happiness. On this visit of the Bairds, every pleasant day, rides, calls and excursions were planned and enjoyed. On dull or rainy days the two friends were delightfully employed. Mr. Boardman records: "September $6-$ Very fine day. Went down to the Simpsons. Had a gay time-picnic and digging for Indian relics." Another day they went to 


\section{THE NATURALIST OF THE ST. CROIX}

Conners' place at Oak Bay. Sepiember 8 was " a rainy, dull day; labelled some birds with Prof. Baird." 'The following day was one of very high wind and the two naturalists " numbered and labelled eggs all the afternoon." September 10 was dull and foggy and they "arranged the bird collection" in the bird house. What happy days were those! And so the brief records in the diary go on until the Bairds left for Washington; the days became shorter and Mr. Boardman again made plans for visiting the south.

On the last day of December, 1869, Mr. Boardman left home for Florida. Mrs. Boardman did not accompany him on this visit as, from a letter to Prof. Baird written from Boston, January 3, 1870, "Charley and his wife were to board with her" during the winter. While in Boston he purchased large quantities of supplies to take south with him. Reaching Washington he remained a week, working at the Smithsonian and visiting friends. One entry from his diary, that for January 14 , is a sample of many made at that time: "Worked assorting eggs all day at the Smithsonian." On his journey south he stopped at Richmond, Wilmington, Charleston and Savannah and reached Fernandina on January 20. Writing to Prof. Baird from Charleston, January 17 , he says : "Tell Mrs. Baird I hardly know how we should have got along without the sandwiches. They were just the thing. Yesterday a boy came into the cars to sell wine and on the seat we had the sandwiches and two kinds of wine. So you may be assured we drank to our friends' health." 'The winter was spent at Jacksonville, Hibernia, Greencove Springs, Orange Bluff, Valusia and other places. In a letter to Prof. Baird, dated February 6, he writes : 
Hibernia, Fla., Feb. 6, 1870.

DEAR Pairu :

I want to tell you what an exceedingly good place $I$ am in to collect common birds. It was many years ago an old plantation, now grown up seantily to trees; no underbrush and very good walking:. The trees are full of birds, nothing very rare, but you can harlly go half a mile from the house without seeing more than fifty different kinds of birds; a good many Warblers and Woodpeckers, but not many water birds, except ducks about the river. I expect we shall go into eamp in about ten days; are waiting for a New York man who is to go with us.

I think this would be a nice place to collect eggs. I never saw such an abundance of old nests. I have engaged a young man to look after them. I see many woodpeckers looles and if the boy tries he can get some good eggs. One of the red-bellied kind is now digging a hole next the house and the red cockade must nest all about. He tells me that the Red Wing remaius here all summer, also the Bluebird. One cuckoo and several kinds of blackbirds, atso many of the hawks are found all summer. 'The only duck that remains is the Wood Duck, he thinks. I will leave him uny drills and blow-pipe and hope he may get some eggs new to your collection and I will collect some Florida birds for Ridgway to compare with the northern. I have some blackbirls, I think of northern and southern, as they differ considerably in size. 1 am yours ver'y truly,

Geo. A. Bohizhax.

Here is an extract from another letter of about the same date as the preceding: "I find birds are very local in their habits in Florida. I find different birds at Jacksonville from even Greencove Springs, and then different at Palatka from what they are at St. Augustine; another kind at Enterprise." On March 30, Mr. Boardman writes to Prof. Baird that he intends to leave in a day or two for the north and "be along toward Washington by Saturday or Sunday night unless detained on the way. If you have a spare bed for a night or two I will occupy 
it ; if not, all well." He left for home April 2, reaching Washington April 4; attended a party at Prof. Baird's April 5, reached Calais April 21 and the following day "called all round to see the folks."

The summer of 1870 was passed quietly at home. Mr. Boardman did not at first intend to go south in the winter of 1870-71, but as cold weather approached he was anxious to get upon his favorite winter collecting ground. Even so late as October 16, 1870, he wrote to Prof. Baird: "I am not certain about going south again this winter but think perhaps I may. Mrs. Boardman and Willie will probably go with me if I go. I must try to go to some new locality as I am too much at home about Jacksonville." But on December 2, he writes his friend : "We hope to leave for the south the last day of this month if all is well," and they did, it being the same date on which they left the previous year. He adds: "I shall not want to make much of a stay in Washington, having been there so often. We shall wear our welcome out and I shall not be a rare curiosity at the Smithsonian." On this trip to the south Mrs. Boardman and their son IVilliam $B$. who was then nine years old, accompanied Mr. Boardman. They reached Washington January 11, 1871, remaining five or six days. Mr. Boardman spent the time at the Suithsonian and also attended receptions at Prof. Baird's and at Senator Edununds'. Jacksonville was reached January 19. The winter was spent at Jacksonville, with visits to Palatka, St. Augustine, Hibernia and other places, where, according to entries in his diary, he "called all round to see friends." March 8 he "picked orange blossoms" and March 28 "shot eleven cedar birds at one shot." They 
left for the north A pril 8 and, after brief visits at Washington, New York and Boston, reached home April 21. The summer was spent at lome and was exceedingly quiet.

The winter of 1872 was spent in Filorida, Mr. Boardman having left home January 8 and arrived at Jacksonville January 26. It was one of the busiest and happiest winters Mr. Boardman ever spent at the south. Among the places visited were Hibernia, Magnolia, Port Royal, Enterprise, Orange Bluff, Lemon Bluff and St. John Bluff. He went up the St. John river to Lake Jessup, Lake Widner and Lake Washington. There was hardly a day, Sunday excepted, when Mr. Boardman was not busy with his sport and collecting, down to the time he left for the nortl, April 12.

His diary for this winter is full of most interesting records. Among the birds shot were: Snipe, Florida jays, ducks, wild turkeys, plover, white heron, blue cranes, gannets, night herons, pelicans, wood ibis ; while he also records shooting alligators and deer. March 8 , he records: "Shot bircls all day;" and March 9, he records: "Shot birds all day; deer, turkey and suipe plenty." Other records are: "Skinned birds all the forenoon."

If the winter of this year was full of enjoyment to Mr. Boardman the summer was equally full of pleasure. Prof. Baird and his family made the Boardmans three or four visits and their house was full of guests much of the time. Prof. Baird was passing the summer at Eastport and with his family he visited Mr. Boardman in June. Again in August the Bairds and the Boardmans macle a visit to New Brunswick, Nova Scotia and Prince 
Edward Island, going to St. John, Halifax, Annapolis, Charlottetown and Summerside, calling upon scientific friends and visiting at St. John the natural history museum. Again in September, before leaving for Washington, Prof. and Mrs. Baird again visited the Boardmans.

After having spent several weeks with friends in Boston and Brookline, Mass., in the early winter of $1872-73, \mathrm{Mr}$. and Mrs. Boardman left for Florida January 6 and, without stopping at Washington, reached Jacksonville January 14. His diary shows that after arriving and having made calls upon all his friends Mr. Boardman at once commenced his favorite pursuits of shooting, skinning birds and mounting specimens. This was his constant employment and the records in his diary show what birds lie shot and mounted each day. On February 10, 1873, the little steamer Clifton was launched. She was built in Philadelphia by a party of gentlemen from Clifton Springs, N. Y., among whom was Dr. Henry Foster, head of the Sanatorium at that place, who was one of Mr. Boardman's intimate friends, the two having been together in Florida for two winters. The places on the upper St. Johns river were then comparatively wild and game was abundant. Mr. Boardman went farther up the river that winter in the Clifton than any sporting party had been previously. The Clifton only drew twenty inches of water; she had a crew of three men and had accommodations for a party of six. In a chapter contributed by Mr. Boardman to camp life in Florida, published at New York in 1876, he says he was on board of her for two winters and had a splendid time. "Such a boat," he says, "can go to the upper waters of the St. Johns 
river, above where hunters generally go and where game is plenty. Such bird suppers as Reuben could get up I never expect to see again." After spending a very pleasant winter south, Mr. and Mrs. Boardman left for the north April 3 and arrived home May 2. The very next day, as was his usual custom, he "went all round to see friends" and also went to get Mayflowers. The summer was spent quietly at home and the diary records days of shooting, what birds were obtained and how many, with work in the bird house, mounting and sending away specimens to his friends and correspondents, labelling eggs and skins with other similar details of employments in which he deliglited.

That well-known sporting and naturai history journal, Forest and Stream, was established by his friend and correspondent, Mr. Charles Hallock who was its editor for many years. The first number was dated August 11, 1873 and Mr. Boardman's name was the second one placed upon its subscription books. In number five of that journal, dated September 11, appears an article by Mr. Boardman, written in answer to a request from Mr. Hallock, entitled Attractions of Natural History, which is here given. It is signed George A. Boardman (Naturalist):

I am more than pleased with the first two numbers of the Forest aud Stream. Stich a paper, I think, is very much needed to educate our people to out-door exercises and sports and to the study of natural history in some of its brauches. 'l'o the lover of the beautiful - to one who delights in the gity, bright beings of nature, ornithology is one of the most attractive branches of Natural Science. How little most people know of the number and variety of birds that anuually visit every part of our extended cline, or are even aware how many spend the summer in our immediate vicinity. 


\section{THE NATURALIST OF THE ST. CROIX}

We little think that any time we walk in our grounds and gardens we are intruding upon rare and elegant visitants from Mexico, Central South America, Florida and the islands of the sea, but such is the case, and one that passes through life without a knowledge of the feathered creatures constantly surrounding him, in the fields and woods, reudered vocal with their songs, watching the patience and care in providing for their young, loses one of the chief means by which his own existence might be made more cheerful, happy and contented and fails to understand one of the most pleasing and attractive of the creations of Omnipotence. How importaut for the sportsman to know the history and habits of his feathered friends so as not be let to slaughter them out of season. And the agriculturist, after failing erops and barren fields, only learns the errors he has committed in the destruction of his little help mates, by the life and vigor it has given to the grubs and insects that now overrum his fields. Our English friends I think are much in advance of us in their papers upon Natural Science. But now with the help of the Forest and Stream which I hope may go into every family, we may try to surpass our English friends in the study of vatural science and know the benefits of out-door recreation and physical culture.

In the spring of $1874 \mathrm{Mr}$. Boardman made a trip to California, leaving home March 2, bearing an introduction from Prof. Spencer F. Baird of the Smithsonian Institution. In sending this letter of introduction to Mr. Boardman, Prof. Baird writes: "I hope this will bring you in communication with the scientifics of that state. Dall is there, having just returned from the South coast and will be very glad to see you. I hope you will return by way of Washington so as to give us an account of your adventures. Please pick up whatever you can for us of rare birds and eggs, Indian relics and the like." Enclosed in the letter is a list of persons to whom the introduction was to be presented. Among them were: R. E. C. Stearns, I. W. Raymond, Prof. George Davidson, 


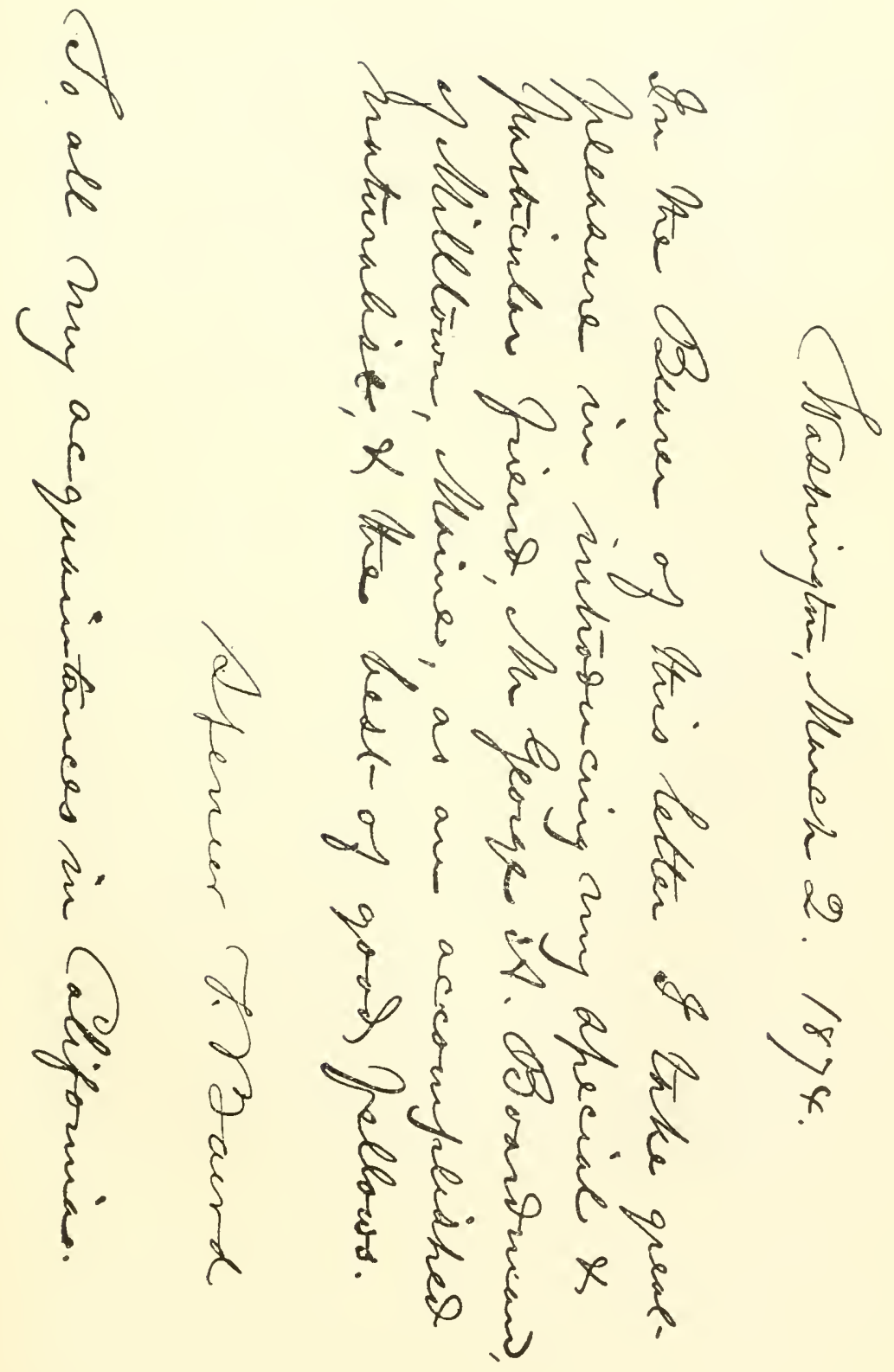



Wm. H. Dall, Prof. J. D. Whitney, Dr. J. G. Cooper, Dr. Wm. O. Ayres, R. B. Woodward, Ferdinand Grieber and John Williamson. On this visit Mr. Boardman went to Sacramento, San Francisco and Oakland. He also visited St. Helena and the White Sulphur Springs, went to the petrified forest and the geysers where he "took a steam bath and walked up the mountain." While in California he did some collecting and mounted some birds. He reached home on May 15 of that year. At the close of his diary for the year is the memorandum : "Game shot, 1874-19 duck, 48 partridge, 111 woodcock, 78 snipe."

Portions of the winters of 1875,1876 and 1877 were spent, as had quite become Mr. Boardman's custom, in Florida. He did not leave home in 1875 until February 10 and, returning on May 7, again left for the south December 20 of the same year. It was after his winter in Florida of that year that Mr. Boardman wrote that chapter of his experiences which appears in Mr. Hallock's Camp Life in Florida which gives so graphic an account of winter life in the land which he loved next to that of his own northern home. The winter of 1875-76 he remained in Florida until the first of April, being nearly a month on the homeward journey, reaching St. Stephen May 5, 1876. Again on December 26, 1876, $\mathrm{Mr}$. Boardman started for the south. In the early winter of 1875 he was in Florida but a few days more than two months, spending the time at Jacksonville, Arlington and Greencove Springs. On his return he made his usual visits to scientific friends at Washington, Philadelphia and New York, at the latter place always visiting the 


\section{THE NATURALIST OF THE ST. CROIX}

Central Park and at Washington the Smithsonian Institution. Mr. Boardman's visits south during 1876 and 1877 were but a repetition of those of previous years. He was happy in meeting his many friends, liappy in his collecting, being always on the watch for something new, packing and sending away boxes of specimens, while his ever genial temperament found many occasions for giving pleasure to those whom he met. Writing letters to friends was a pastime he much enjoyed and his correspondence took much of his time. In September and October, 1876, Mr. Boardman spent a week at the Centennial Exhibition at Philadelphia, for some days being in company with Prof. Baird. During his winter at the south this year he was joined by Prof. Baird and Dr. Foster and these friends had a fine time together for two weeks in the montl of April. On Mr. Boardman's return north, while at Charleston, S. C., he "went up in a little steamer to Magnolia and Draton Hall to see the flowers; gone all day" - as he records in his diary. When in Washington he attended a dinner party at Senator Edinunds', accompanied by the Bairds. In the summer and fall of 1877 he visited Fredericton, St. John, Halifax, Pictou, Summerside and Shediac.

Mr. Boardman had now spent eight winters in Florida. Splendid field naturalist that he was before he went there, he had added largely to his knowledge of birds by these visits and had by eight years' collecting and study of birds in their southern homes, become very familiar with the ornithology of the south and with the migratory habits and climatic range of our native birds. He had also spent one spring in California. During his journeys to and from his lome and the south he had made visits 
of more or less duration at Washington where he had spent much time at the Smithsonian Institution and had become acquainted with nany of its force of scientific workers. But in order to more thoroughly study the bird collections at the Smithsonian he had planned for sone years to spend an entire winter in Washington, thus supplenenting his keen and accurate knowledge obtained from field study by a careful comparison of specimens in the Smithsonian museum.

Accordingly it was decided that the winter of 1878 should be spent in Washington and on Jantury 3 of that year, in company with Mrs. Boardman, he left for the national capital where they arrived January 5, taking rooms at 1217 I Street. They remained at Washington until April 5, when they started on the return home, reaching Milltown, N. B., April 16.

The winter spent in Washington was a most delightful one to Mr. Boardman. He was at the Smithsonian nearly every day engaged in study or in work - in examining the collections for his own benefit and instruction or in assisting at naming and arranging the new things being constantly received. He also attended the scientific meetings - as he records in his diary - met the Institution workers - Prof. Baird, Elliot, Henshaw, Ridgway, Hayden, Myers, Coues and others and enjoyed the society of his many friends at the national capital. He was often at Prof. Baird's to dinner, spent many of his evenings there and made frequent visits to Senators Hamlin and Edmunds, Mr. Blaine and other prominent personages in Washington society. Mr. Boardman was widely known as the Maine naturalist and had entrance to the select scientific circle at that great centre of science, 


\section{THE NATURALIST OF THE S'T. CROIX}

while the charming manners of Mrs. Boardman endeared her to all and together they attended dinner parties and receptions at several places where they were always esteemed guests. Thus to the solid enjoyment of the study of science were added the charms of society of which Mr. Boardman was fond and to which he contributed so much of pleasure to both host and guests.

During most of the winter which Mr. Boardman had spent in Washington, Prof. Joseph Henry, who had been secretary of the Smithsonian Institution for a period of thirty-two years, had been in failing health. On reaching his home in Milltown that spring, Mr. Boardman received a letter from Prof. Baird informing him of Prof. Henry's death which took place May 13, 1878 and also of his own election as Prof. Henry's successor. In a letter to Prof. Baird, dated May 22 of that year, Mr. Boardman wrote: "I am sorry to hear of the death of Prof. Henry; although knowing how ill he was when we left Washington I was not at all surprised to read of his death. I was much pleased at the vote you received to make you the head of the institution - the office that you have richly earned." This extract from Mr. Boardman's letter is most characteristic of the man-plain, straightforward and business-like, with no attempt at undue praise or eulogy, just the simple, sincere expression of a true friend unused to the multiplication of words on any occasion, but making use of plain sentences full of meaning. A memorandum at the close of Mr. Boardman's diary for 1878 gives a list of fifty-six names of naturalists with whom he had been in correspondence during the year. The list embraces many names of persons eninent in science in this country, in New Brunswick, in Nova Scotia and in England. 
The year 1879 was spent by Mr. Boardman at home. There was hardly a day down to the first of September that he did not go to his favorite shooting grounds, work in his bird house, send off a box of specimens to some friend or write several letters to some one of the many naturalists with whom he kept up a correspondence. His diary shows that during the winter he worked much in his bird house, drove out almost every day, visited friends and went skating - a sport of which he was fond. As the spring came on the entries in his diary become more interesting. April 22 he "saw a snake on the snow." The first martins came April 26, April 28 he went out after snipe and "got a few." He went often to the Maguerrawock and Mohannes streams - his favorite resorts for water birds. He records: "May 19 - went up to Uncle Steve's woods ; got warblers, several kinds ; named all when I got home." In June Mr. Boardman made a short visit to Boston and New York. Through June and July he was out shooting nearly every day and his diary records getting woodcock, young hermit thrush, wood duck, house wrenl, snipe and other birds.

On September 4, while out shooting at Clark's, Mr. Boardman had the misfortune to injure one of his knees. How it occurred is not recalled but he records it in his diary as a "bad accident" - and it must have been a bad one, otherwise he would not have so written. In the same entry he says: "Saw many woodcock; got two." The day following, however, finding himself greatly disabled, he sent for Doctor Knowles to attend him. The result was that, although Mr. Boardman drove out almost daily during the fall of 1879 , worked in his bird house, mounted some specimens, was present at the 


\section{THE NATURALIST OF THE ST. CROIX}

meetings of the directors of corporations of which he was a member and attended to his usual business duties, he was prevented from ordinary work and at the close of the year he records: "Lame knee has kept me on crutches since 4 September." It did, in fact, keep him on crutches for nearly six months beyond the time at which that record was made. His list of correspondents for the year comprises forty-three names, nearly all of them those of leading naturalists of this country and abroad.

Late in the spring of $1880 \mathrm{Mr}$. and Mrs. Boardman left for the west, arriving in Minneapolis where four of their children were then living, on May 7. Three days afterward, as he records in his diary, Mr. Boardman went for birds, getting grosbeaks, orioles, jays, etc. Almost every day for several weeks following he went birding every forenoon and in the afternoon worked at skinning and mounting birds. Among the entries in his diary are: "Grot orioles, rose-breasted and scarlet tanagers;" "went to Minnesota bottoms-shot duck, quail, yellow headed blackbirds;" "got white kingbird;" "went to Lake Calhoun; seven black terns, two yellow heads, two orioles, larks, blackbirds; " " dinner at Albert's - had mallard ducks ; " "went to Minnesota bottons with Willie - shot yellow-head blackbirds, scarlet tanager, grosbeaks and larks." While on this visit he lost no time in becoming acquainted with the birds of the west, both in the field and at the collection of the University of Minnesota where he spent many days. A letter to Prof. Baird gives an interesting account of his impressions of the western fauna. He was yet suffering from the accident to his knee and was obliged to use crutches, as a reference in the letter will indicate : 
Mindeapolis, Minn., May 21, 1880.

\section{My Dear Professor:}

I know I owe you a letter and should have written before I left home; had I hat much of any news to communicate should have done so.

We have been here two weeks to-day, found the boys and families all well and very glad to see us.

I was very much surprised to see how much more forward vegetation was than with us in the same parallel. We found in the first week of May the trees nearly leaved out and trees in full bloom about the same as we see in southern Massachusetts or Connectieut. 'The boys at the University found thirty-four different kinds of wild flowers in the first week in May. We could hardly do that in New Brumswick. We are much pleased with the looks of the country; it is quite warm but the air is delightful. Mrs. Boardman is in love with the country. We find very many of our old down east neighbors and we see about as many old acquaintances as at home, so many of the men that have been in my employ years ago come west. We are full of eallers all the time. I have been riding all abont. See lots of nice birds, many nearly new to me. Yellow-headed blackirds are very abundant, black tern by the thousands, every little lake hovering about like swallows. Rose breasted grosbeaks very abundant as well as orioles and some scarlet tanagers. 'The warblers had mostly gone north. I got one Cape May and they appear quite common. One lake near here there is an island where hundreds of blue heron are now breeding. Double erested cormorants breed on the same trees, and blackbirds in the foundation of same nests.

If my locomotion was better I should enjoy being here in the spring eollecting, but can walk but a little distance; an getting better most every day. Ilope to be well enough in a few weeks to go up to Fargo and perhaps up the Red Rivel to Winnipeg. I should enjoy the sail up but hear mosquitoes are very plenty. 'The fisl are most of them new to a Bay of Fundy chap. 'The bass do not look like the Florida fish, and the Mimneapolis folks get very good fish from Lake Superior, some very large and good eating fish. I see reports of Prof. Goode and your fish exhibition. Have no doubt they will be a eredit to the country. I expect you 


\section{THE NA'TURALIST OF THE ST. CROIX}

are beginning to make a good show in the new building by this time; hope to see it next fall. All join in much love to you, Mrs. B., Luey and all the friends.

Sincerely yours,

Geo. A. Boardman.

On this visit west Mr. Boardman went to Fargo and returning, was active in his study of western birds in the few days before leaving for home. He went to Lake Minnetonka where he "saw swallow-tails, buzzards, cranes;" he "went over the river to see German bird men;" he "went to the Academy of Sciences; " he "went out shooting, got nest and chick of gallinule, indigo birds, etc., and skinned birds," and "called at William Grimshaw's to see his eggs" - these are the entries in his diary down to the very day of leaving for the east, June 23, 1880. During that summer Mr. Boardman made visits to Boston, Fredericton, St. John and Woodstock and in October attended the exhibition at St. John. Some entries in his diary will give an idea of how his days were spent in the autumn of that year: "October 9: mounted hawk and blue birds; afternoon out to Jones'; two woodcock, one snipe ; Jones shot golden eagle and one partridge. October 11 : Skinned golden eagle; out to Jones' afternoon, got two snipe, one woodcock. October 12: Went out to cemetery; Mrs. Lovejoy and Ladd at tea; had bird supper. October 13: Went out to Chandler road with Osborn; got five woodcock and barred ow1. October 14: Afternoon out to Tyler's ; got two woodcock, saw six; mounted barred owl. October 15: Afternoon at Maguerrawock with Osborn ; no snipe on meadows; got six woodcock, yellow rail, partridge. October 16: Out to Jones'; got one woodcock, one snipe, 
six partridge. October 18: Went out to the Mohannes with Everett Smith of Portland, game commissioner for Maine. October 19: Mounted spruce partridge and barred owl. October 20: Went to Clark's with Everett Smith, got two partridge, one woodcock; afternoon worked in bird house. October 21: Worked in bird house most all day." On November 24, 1880, Mr. Boardman "sliut up the house for the winter" and left for Florida, arriving at Jacksonville December 24. December 30, Mr. Boardman records: "Thermometer 17 - coldest for forty years ; oranges all frozen on the trees." His list of correspondents for that year numbered fifty-eight.

Three or four entries from Mr. Boardman's diary will show how the days were spent during the winter months in Florida : "January $28-$ Went out slooting with Mr. Page of New York; got some snipe, plover, red birds, etc. February 1-Made skin of fish crow ; got evening grosbeaks. February 24-Mounted birds and trimmed orange trees. March 3 - Skinned two ivory-bill woodpeckers, mounted birds and trimmed trees." On Sunday, March 6, Mr. Boardman heard Bishop Whipple preach at Sanford, Fla., where he was passing a vacation. The two following days he went to Lake Jessup "fishing, shooting and picnicking with Bishop Whipple." How the two naturalists must have enjoyed each other's company! Devout Christian that he was, Mr. Boardman took pleasure in hearing the Bishop preach on Sunday, while Bishop Whipple, lover of nature and also a sportsman, enjoyed fishing and shooting with Mr. Boardman on Monday. Rev. Henry Benjamin Whipple was the first bishop of Minnesota and used to pass his winter vacations at various points in Florida. He died Sept. 16, 
1901 and the memorial tower of the Episcopal cathedral at Faribault, Minn., has been consecrated to his memory.

During that winter in Florida Mr. and Mrs. Boardman passed the time at Palatka, Enterprise, Sanford, St. Augustine and Jacksonville. His son Charles was then living at Palatka and they made their home with him, going to the other resorts for a longer or a slorter time as the inclination possessed them. Mr. Boardman did not do as much collecting that winter as formerly. Their friends, the Fosters from Clifton Springs, N. Y., were in Florida that winter and much time was spent with them in excursions and pleasuring parties. They left Florida April 11 and arrived in Washington April 14. A stay of only two days was made in Washington when they left for the east, spending four days in Philadelphia, some time in New York and Boston, arriving at Calais on May 13.

Reaching liome Mr. Boardnian immediately went to work in his bird house, according to entries in his diary, and also took up his excursions to the woods and waters of the Maguerrawock and Mohannes and almost every day throughout the month of May and June recorded getting warblers, blackbirds, lots of ducks, redwings and other birds which he skinned and mounted, also going on fishing trips. He continued to send specimens to the Smithsonian Institution as usual. Among his papers is an acknowledgement from Prof. Baird, dated June 25, 1881, in which he says:

The specimens announced by you on the 19th came safely to hand and we are greatly indebted to you for the interesting contribution. The Florida lrawk is extremely acceptable and I think Mrr. Ridgway has written you for futher particulars. 'The " 
flounder is, I think, the same as one previously sent by you from Mr. Wilson's weir. It is known in New Jersey as the Windowpane, from its thinuess (Lophopsetta Maculata). The sandpiper, with the musele attached is interesting and serves to illustrate the methods by which animals become distributed from one point to another. I shall be very glad to have good samples of the red granite, including a four-inch cube and one of a foot and anything else in the way of style or pattern.

During the late summer and fall of that year Mr. Boardman records the trips to his favorite shooting grounds where he got young petrel, black gallinule, marsh hawk, reed bird, kingfisher, wood duck and partridge. On November 14, having closed his house for the winter, $\mathrm{Mr}$. and Mrs. Boardman again left for the south. They made but brief calls on the way in Boston and New York, arriving at Jacksonville November 19. According to the records in his diary Mr. Boardman had corresponded during the year with seventy different persons, to more than thirty of whon he wrote frequent letters. On December 31 he received a letter from Prof. Baird telling of his disappointment at not having a visit from the Boardmans on their passage through Washington for the south. Prof. Baird writes:

Dear Mr. BoARDMAN :

Wasmington, D. C., Dee. 29, 1881.

We were quite surprised to get your letter from Palatka, when we were trying to intercept you on the way through Washington, wishing you to pay us a visit. I hope you will take Washingtou on your return, and that Mrs. Baird will be well enough to have you and Mrs. Boardman come directly to our house. I cannot bear the idea of having you go off to the far west without our seeing you. One comfort, however, will be that you will continue to go to Florida as heretofore.

I wish very much you would consider yourself a special agent of the Smithsonian and National Museum along the line of the 
railroads. Can you not get the boys to take up the subjeet and see that the products of the mounds and graves dug through are seeured for us. 'There are so many outsiders at work in Florida and elsewhere, that we do not get anything like the share we ought to have of the good things going.

of eourse, any rare birds will be weleome. If I knew of some elever taxidermist to send down and make a good eollection of birds I would send him. Perhaps Ridgway himself would like to go and spend a few weeks, at the proper season. What are the chances of getting what I want?

We have nothing specially new here, excejting that Nelson and 'T'urnel' are both back again from Alaska with immense eollections.

I am trying to arrange matters to have a meteorologieal establishment at Ungava Bay and to send a good naturalist in eharge. 'This will give us a first-rate show at the water birds of Hudson's Straits and Northern Labrador. Don't you want to go?

With love to Mrs. Boardman from all of us, believe me, Sincerely Iour's,

S. F. BAIRD.

The winter of 1882 was spent mostly in Palatka, Fla., although excursions were made to several other places. Under date of January 16 of that year Prof. Baird writes him: "I shall be very glad indeed if you can secure for us some of those fine specimens to which you refer. I hope you will constitute yourself a committee of six in the interest of the National museum. If you remain long enough in Florida in the spring I will see if I can not send Mr. Ridgway or some one else to collect specimens under your direction." 'This is one of the many evidences which Prof. Baird had in Mr. Boardman's accurate knowledge of natural history that occur in his correspondence. But little collecting was done by Mr. Boardman during that winter in the south, and on April $6 \mathrm{Mr}$. and Mrs. Boardman left for Washington where they arrived April 
8. A month was spent in Washington and although Mrs. Boardnan's health was far from good it was one of the happiest months Mr. Boardnan ever spent at the national capital. His diary records the happy days spent at the Smithsonian and with Prof. and Mrs. Baird where the Boardmans frequently took tea and spent the evening. Arriving in Washington at 9 o'clock a. m., on Saturday, April 8, Mr. Boardnan at once went to the Smithsonian, and on Sunday evening, with Mrs. Boardnian, he took tea with Prof. and Mrs. Baird. A few of the brief minutes are given from Mr. Boardman's diary as showing how the days were spent: "April 10-At Smithsonian to look over Nelson's arctic birds. April 11-Called round to see all the friends at the Smithsonian. April 17 - All day at the museum; walked up to Prof. Baird's. April 18-Went over to museum; Acadenuy of Science in session; reception at museun. April 19-At Smitl1sonian; went about with Prof. J. W. P. Jenks, curator of museum, Brown University. April 22-At museum with Mr. Walker and the ladies; Dall's lecture at museun. April 28-Packed birds at Smithsonian. May 2-Spent the day at the shad hatchery at the Smithsonian; packed box of birds. May 4 - Over to Smithsonian and called with Prof. Baird to all the offices and visited the carp ponds. May 5-Over to Smithsonian; got some birds of Mr. Nelson. May 6-Over the Smithsonian to say good-by to the folks." On May 7, which was Sunday, the Boardmans spent the afternoon and evening at Prof. Baird's and on the next day left for the north. The summer of 1882 was passed at Calais.

On September 4 Mr. and Mrs. Boardman left for the west. 'They had no sooner arrived at Minneapolis than 


\section{THE NATURALIST OF THE ST. CROIX}

Mr. Boardman "went out to Great Marsh and shot 12 snipe near Rice Lake." During that fall he went to Fargo, visiting a large farm in which his sons were interested and where he saw "lots of wild geese." He also shot "hawks and black vulture," and at Sanderson "went out to see eagle's nest." On October 4, he went to the big marsh snipe shooting where he shot a redtailed hawk, which was mounted the following day. This was a favorite place with Mr. Boardman where he often went slooting. On October 18 he records: "Shot two snipe on railroad near the house."

The winter of 1882-83 was spent in Minneapolis. That Mr. Boardman kept up his interest in ornithology is shown by the many entries in his diary from which some extracts are given: "January 3, 1883-Coldest of the season: 12 degrees below all day; Shot two evening grosbeaks. January 11 - Skinned four evening grosbeaks. March 8 - Went over to see the old German bird man, afterward at rooms of Academy of Natural Science. March 25 - Skinned three"evening grosbeaks. March 27 - Over east side to see the old taxidermist. March 31 - Got two evening grosbeaks and skinned them. April 16-Got one Hooded Merganser and skinned it; in aftermoon went shooting and got snipe and ducks. May 9 - Skinned pintail duck. May 21-Went to Lake Harriet; shot two horned grebes and one red throat all in good spring plumage."

Mr. and Mrs. Boardman arrived in Calais from the west on August 7, and the first of September had a visit of some days' duration from Gov. and Mrs. Robie. 'The last of October and first of November of that year Mr. Boardman was occupied in moving the contents of his 
bird house from St. Stephen to Calais and putting up his collection of birds, eggs and nests in his new museum. He records the number of loads and notes the days spent in "arranging his bird house." His diary for that year records the names of eighty-four persons with whom he had been in correspondence during the year, many of them those of well-known scientists - Prof. Baird, Geo. N. Lawrence, Mrs. T. M. Brewer, E. Cones, Everett Smith, I. Nesbitt, H. E. Dresser, W. T. Hornaday, N. Clifford Brown. The following letter may well close the record of the year 1883. It is one of the last received from Prof. Baird and shows conclusively that he regarded the work of Mr. Boardman upon the birds of Eastern North America as practically complete. The list enclosed in the letter is endorsed: "Additions to Mr. Boardman's Catalogue of the Birds of Calais, Maine, 1862, included in Prof. Baird's manuscript supplementary list; thirtytwo species, nomenclature of 1859 catalogue; R. R." (Robert Ridgway) :

\section{DeAR Mr. BOARDitaN :}

Washington, D. O., Dec. 10, 1883.

Many years ago I undertook, during one of my visits to Milltown, to help you with a catalogue of birds of eastern Maine and between us we made out about thirty-one species in addition to what you had previously reported upon. 'This list has been among my papers for probably fifteen years or more, aud coming across it a few days since, I spoke to $\mathrm{Mr}$. Ridgway about putting it in form and arranging for its publication either in the proceedings of the Boston Society of Natural History, or of the National Museum - you to be the author of the paper.

I now send you the names that I have, so that if you think proper you may make any additions thereto that oecur to you. It would be well to add auy paragraphs about dates, habits and conditions of discovery. 


\section{THE NATURALIST OF THE ST. CROIX}

If you will then send it to me, I will get Mr. Ridgway to complete it as proposed. It is not very likely that you will make many additions to the list; at any late, I do not think it is worth while to wait much longer.

Yours truly,

S. F. BAIRD.

Mr. and Mrs. Boardinan spent the winter of 1884 in Florida, although Mr. Boardman did but little collecting. Almost the only entries in his diary which refer to this are the following: "February 4-Went to ride out in the pine woods witlı Mrs. Boardman; got a few birds; afternoon, mounted three birds. February 5 - Went out in pine woods with ladies; shot blue bird; afternoon, mounted bird.' 'They were then at Palatka. They arrived in Washington on their return east, April 7, where they remained ten days. It was the usual round of pleasure and study. They called upon members of the Maine delegation in Congress, attended receptions and visited friends. Mr. Boardman was at the Smithsonian, at the National Museum and with Prof. Baird nearly every day and on different days he records in his diary : "Called all round to see the folks; at the Smithsollian saw Prof. Baird, Prof. Goode, Ridgway, Eliot, Capt. Bendire, Coues and Hornaday; took over burrowing owl and Limpkin eggs to museum; went to fish hatching-house and museum, got birds of Ridgway and eggs of Capt. Bendire; saw Prof. Verrill, Dall and others and went over to Academy of Science; all day at museum, saw Dr. Hayden, Coues and others.' Reaching New York on his journey home Mr. Boardman spent a few days at the Central Park museum where he saw Dr. Holden, Mr. Bickmore, Mr. Lawrence and others. 
Calais was reached April 29. During the month of June Mr. Boardman was employed in moving from Milltown, St. Stephen, to the house on Lafayette Street, Calais, where he ever afterward resided and almost daily entries are made in his journal of work done in arranging the collections in the museum. Almost the only entry relating to birds is: "June 10 -Afternoon went up to the old pasture and got four Loggerhead Shrikes, White Rump, first ever collected here." The diary records seventy-eight correspondents for the year.

The years 1885 and 1886 were passed by Mr. Boardman at home with the exception of visits to Boston, New York and the west - the summer of 1886 having been spent in Minneapolis. The year 1887 was also spent quietly at home with visits to Boston and Fredericton. The death of Prof. Baird occurred in August of this year, Mr. Boardman making a brief entry of the event in his diary of August 19. 


\section{CHAP'TER V}

\section{CLOSING YEARS AT CALAIS.}

THE work of Mr. Boardman as a naturalist really 1 ended with the death of Prof. Baird in 1887. Indeed, four years before Prof. Baird's death he had written Mr. Boardman that it was not likely he would make any additions to the list of Maine birds and suggested that the list should be revised and published as a final work as he thought it not advisable to wait longer for new species. Mr. Boardman's friendship and correspondence, his visits and exchanges with Prof. Baird had continued uninterruptedly for a period of twentyseven years with the closest intimacy and delight. Now he had gone. His friend and correspondent, Dr. William Wood of Connecticut, had died in 1885 and John Krider in 1886. The last letters from Mr. Dresser that have been found among Mr. Boardman's papers were written in 1874. Mr. Boardman still wrote occasionally to Mr. Charles Hallock and to Prof. Robert Ridgway for he loved to be in communication with his friends. On April 4, 1887, Mr. Boardman wrote to Prof. Ridgway : "I have received several letters through the winter from Prof. Baird. He writes me how poorly he has been in 


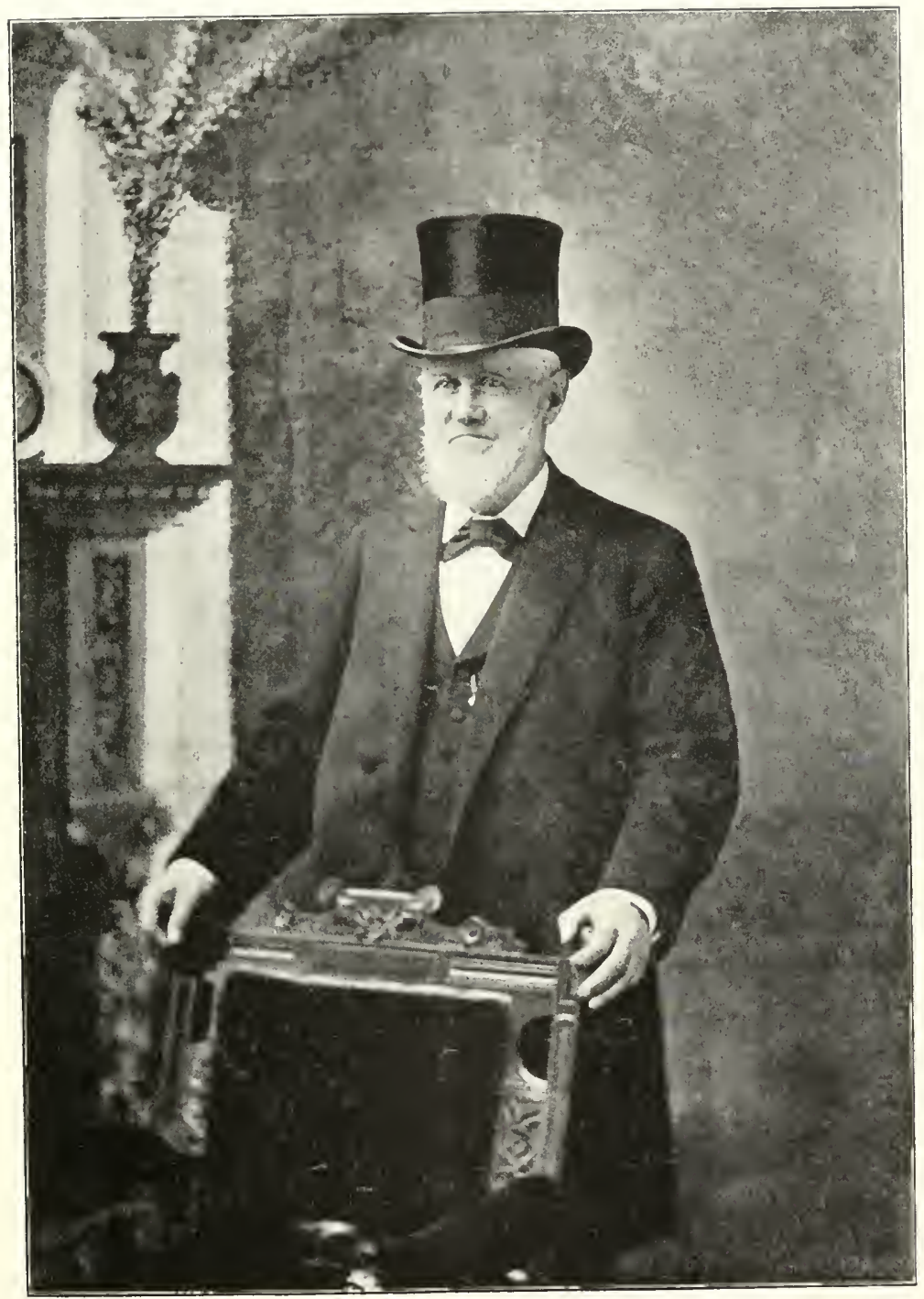

GEORGE A. BOARDMAN

At the Age of about Eighty years 
health; has lost over twenty pounds of flesh. I cannot find out what the trouble is with him or really how badly off he is. In his last letter he wrote me he was going to Vermont to spend the first part of the summer and leave the sea air. I wish you would write me all about him ; how he has been and how he appears. I hope he is not going to break down." In reply to this Prof. Ridgway wrote :

\section{DEAR Mr. BOARDMAN:}

Sumtisonian Institution, $A$ pril $16,1887$.

Since the receipt of yours of the 4 th inst. I have been so busy with my new book (Manual of North American Birds), endeavoring to hasten its completion by the commencenent of the colleeting season, besides my other necessary occupations, that I have been obliged to defer an answer until today.

I am very happy to tell you that Professor Baird's health seems much better, as he not only goes about more but tak's his former interest in various matters and appears altogether more cheerful than he did a few months ago. At one time he seemed to be very mueh discouraged and all his friends felt very apprehensive, but I sincerely trust that the worst is over now, and that he will be spared to us for many years yet. His loss would be an irreparable one to his friends, for no one could replace him. IIe is going to the Adirondacks about the first of June and the change, as well as freedom from the many eares, responsibilities and annoyances which beset him here, will no doubt do much to restore him to good health.

There is nothing specially new here, birds coming in frequently, but rarely anything of particular interest. We have had no very large collections since the Albatross collection came in. It will probably interest you to know that we have three additional speeimens of Wurdemann's Heron, and I have examined five nore - eight altogether, in addition to the type. They all came from the Keys near Cape Sable, where they were breeding in December. 


\section{THE NATURALIST OF THE ST. CROIX}

Dr. Stejneger, who is busy as ever, working chiefly on his review of Japanese birds, sends kind regards, as does also

Yours truly,

Robert RIDGWAy.

Writing to Prof. Ridgway on December 13, 1887, Mr. Boardman says: "I have not written you for a long time, not since the death of our dear friend, the professor. Mrs. Baird has written me all the particulars of his sickness and death. Since then I have seen several notices and accounts of him, one I think by you at the meeting of the American Ornithological Union. If you have any papers or any duplicates of any memorials of him I would be glad to get them." In the same letter Mr. Boardman adds: "Our plans were to go to Charlotte Harbor, Florida, this winter, but Mrs. Boardman is hardly well enough to go. We may take a run to Washington after a while."

The "run to Washington" was made in the spring of 1888, Mr. and Mrs. Boardman having left Calais on March 8 and arrived in Washington March 11, where they remained nearly a month. They made the usual calls at Mrs. Baird's; Mr. Boardman was much at the Smithsonian where he met Mr. Hornaday, Prof. Goode and others and spent the time much as of old, although the entries in his diary are brief and show a want of interest. "Our dear old friend Prof. Baird," as he always called him in his letters of this period to his scientific friends, had gone and Washington and the Smithsonian were not the same places they had been to Mr. Boardman for nearly thirty years. Reaching Calais from this visit on April 17, the remainder of the year was spent at lome. 

After this it was not as a naturalist studying southern bird-life and making collections that Mr. Boardman visited Florida. He had now spent twelve winters in that State and knew its birds, its animals, its flowers and its people. He enjoyed its winter climate. He had made many friends at all the places where he had collected, but there was now little for him to learn of its flora or its fauna. Still, as he grew older and with the approach of the cold weather of our northern winter he liked to get away from the rigorous climate of the north into that of birds and flowers. So he went south, not with the same object as in former years, but as a gentleman of leisure to visit scenes that had been those of pleasure to him in earlier years and to meet friends of long standing.

In $1889 \mathrm{Mr}$. and Mrs. Boardman left for Florida on January 15 and spent the winter at Jacksonville, Punta Gorda, St. James City, Winter Park, Lake Charm, Palatka and St. Augustine. Leaving Florida the first of April they went directly west, arriving at Minneapolis April 13. Writing to Prof. Ridgway from that place on June 3, Mr. Boardman says :

A few weeks ago I saw a very queer swan here and I think a trumpeter. It was shot up at Dakota. The feet were not the least webbed and there had never been the least sign of toes. It was mounted here by an old taxidermist who would be glad to sell it cheap. It looks queer with its long crane-like toes without webs. If you would eare for it, write me and I will get it for you. I like the spring in this country; I see so many birds and they are so different from those we see in Maine. The woods about the city are full of searlet tanagers, orioles, rose-breasted grosbeaks, redheaded woodpeckers, etc. After I arrived here there were a good many Evening grosbeaks and Bohemian chatterers but all 
left about the last of April although some of them were here until May 10. I don't see much that is new but go out shootiug a few days every week.

His diary for the year gives a list of more than one hundred persons with whom Mr. Boardman had corresponded during the year.

In the early winter of $1890 \mathrm{Mr}$. and Mrs. Boardman left for the south and without stopping at Washington reached Jacksonville January 27. On their return early in April they spent four days in Washington where visits were made at Mrs. Baird's and calls upon members of the Maine Congressional delegation. Mr. Boardman spent two days at the musetum and botanic garden and on April 12, Mrs. Boardman attended the reception of Mrs. President Harrison. They reached home on April 26 and in July of that year Dr. Henry Foster and wife of Clifton Springs, N. Y., whose acquaintance they had made in Florida, visited them for a week. On January 5,1891 , the Boardmans left for the south, arriving at Jacksonville on the tenth of that month. Their friends, the Fosters, were with them for several weeks and the winter though pleasant was uneventful. Mr. Boardman's diary contains no records of interest upon natural history for the entire winter. On April 16 they left for the north, spending but a single day in Washington and reaching home on April 23. This was the last of the many happy winters which the Boardmans passed in the south. Going there first in 1868 they had spent the whole or parts of seventeen winters in Florida during which time Mr. Boardman had become as familiar with its flora and its fauna as he was with that of his own St. Croix Valley. There was nothing more for him to learn, nothing new 
to see and this ended his long series of visits to the land of birds and flowers.

In the fall of 1891, Mr. and Mrs. Boardman spent several months at the Clifton Springs, N. Y., sanatorium, reaching there September 15 and remaining until December 2. For some time Mr. Boardman had suffered from an affection of the throat and nose which proved to be caused by polypi and he went to Dr. Foster's sanatorium for treatment. They were removed on September 30 and 31 and on the following day Mr. Boardman "went to walk and wrote letters." On October 3 , he records: "Saw plovers and cow buntings" - which is almost the only entry about birds in the diary for that year. December 23, Mr. Boardman received a telegram informing him of the death of Mrs. Baird. The diary for this year records the names of one hundred and sixty-four persons with whom Mr. Boardman had corresponded, among them those of his old scientific friends: Henry Osborn of London, Eng., George N. Lawrence, C. Hart Merriam, E. Coues, F. M. Chapman, Everett Smith, Robert Ridgway, N. Clifford Brown, J. R. Krider, J. A. Allen, O. S. Bickmore, William Dutcher, Prof. T. H. Bean and many others.

The spring of 1892 was spent by Mr. and Mrs. Boardman at Clifton Springs, N. Y., and in the west - the months of May and June in Minneapolis with their children. The spring in the west had been very cold and Mr. Boardman records: "May 7 - Martins almost frozen; May 20-Humming birds on the snow." On June 9 and 10 he attended the National convention at which Harrison was nominated for the Presidency. Calais was reached on July 7 and the remainder of that year 
was spent at home. On August 9, writing to Prof. Ridgway Mr. Boardman says: "We have just returned from the west. Did not go south last winter as Mrs. Boardman was not well enough to take the trip. I had a good letter from Mr. Goode in the spring. Should be pleased to hear from you sometime. Has Capt. Bendire's egg book been printed yet? Have you had many new things of bird kind lately? Do you know if Miss Lucy Baird sold her house after the death of her mother?"'

The year 1893 was quiet and uneventful. Mrs. Boardman was not in good health and the year was spent at home. October 6, Mr. Boardman wrote to Prof. Ridgway: "I send the sandpiper bird by to-night's express and think it will not be much of a nondescript to you when you see it, but I cannot make it out to my satisfaction."

Mrs. Boardman's health which had not been good throughout the previous year failed rapidly during the early months of the year 1894. Mr. Boardman had himself been ill from a severe kidney trouble and during the last days of February little is recorded in his diary but that of his own and Mrs. Boardman's illness. The following brief records tell the sad story: "February $24-$ Sick with bladder trouble. February $25-$ Very poorly with bladder trouble. February 26 - Charles came from Fredericton; sick. February 27 -Quite sick. March 1 - Sick. March 2-Sick. March 3-Sick. March 4 - My dear wife died this morning and I so sick could not see her or be with her. March 5-Very fine day; I very sick. March 6-Very fine day; my dear wife buried this afternoon and I could not see her. March 7-Sick." 
Then there are many blank pages in the diary. For the long period of forty-one years it had been kept regularly and uninterruptedly and with only a single day's blank previous to this. Here was the second and for twenty days there are no entries. The long and happy married life liad been broken and liis beloved wife, companion, helpmate and counselor for fifty-one years had left him and he was sick. No wonder there were days when no record could be made and when life itself seemed a blank. On March 24, Mr. Boardman's son, William B., reached Calais from the west and on March 28 his son Cliarles "took him down stairs to unlock the safe." Willian left for Minneapolis on March 30 and on April 7, Mr. Boardman's daughter, Mrs. Taylor and her husband, left for the west. On April 8, Mr. Boardman "went down stairs to dinner for the first time" since his illness. After this friends called to see him, he was soon able to ride out, the entries of daily events were resumed in the diary and life went on much in the old way, as life must go on, how great soever the losses and sorrows which it brings. One record in this year, that of July 15 , is pathetic and touching: "Went to ride up to Maguerrewock and called at Bragg's." It was the scene of his old shooting and collecting days, where he always went two or three times a week and where he took his naturalist and sporting friends and he wanted to see it again. No other record for the year tells so much or is so full of suggestion. It is, indeed, almost the summing up of Mr. Boardman's life as a lover of out door life and sports, of his love for birds and nature study.

The years whicl followed were happy and quiet. Not the old happiness nor the quiet of the earlier years when 


\section{THE NATURALIST OF THE S'T. CROIX}

the time was spent in scientific study-but they were very pleasant years. He wrote less letters to friends than in the active years - their number had grown smaller - but wrote much for the local newspapers and spent a great deal of time in reading. The following appeared in Forest and Stream on March 4, 1899 :

Mr. Charles Hallock calls our attention to an interesting personal item in the Calais (Maine) 'Times, recording that "George A. Boardman, Esq., celebrated his eighty-first birthday at his home on Lafayette street, Sunday, February 5. Callers tendered their most hearty congratulations and all expressed the wish that they might call upon him next year and find him enjoying good health and his usual cheerfulness." 'That which gives point to the paragraph is the fact, noted by Mr. Hallock, that Mr. Boardman was the second name on the list of subscribers anong the patrons of Forest and Stream when it was begun in August, 1873. 'The first subscriber was Gov. Horatio Seymour; and Mr. Boardman therefore enjoys the unique distinction of being the nestor of Forest and Stream readers - and he may defend his claim to the record even against those correspondents who occasionally aver (either through lapse of meinory or by fisherman's license) that they have been reading the paper for thirty or forty years. Mr. Boardman has been a frequent contributor to our columns and we print today some notes from his pen on the queer way of bears.

A letter of about this date written by Mr. Boardman to Mr. Charles Hallock, founder and first editor of Forest and Stream, is one of interest:

My Dear Mr. Hallock:

Calais, Maine, Feb. 12, 1899.

Your kind letter just received. Very glad you and Mrs. Hallock are so well and enjoying yourselves at the south. I often see your name in the Forest and Stream as I have read about every paper since you started it. When you wrote me about starting it, I told you to put me down as the first subscriber, and I believe you said I 



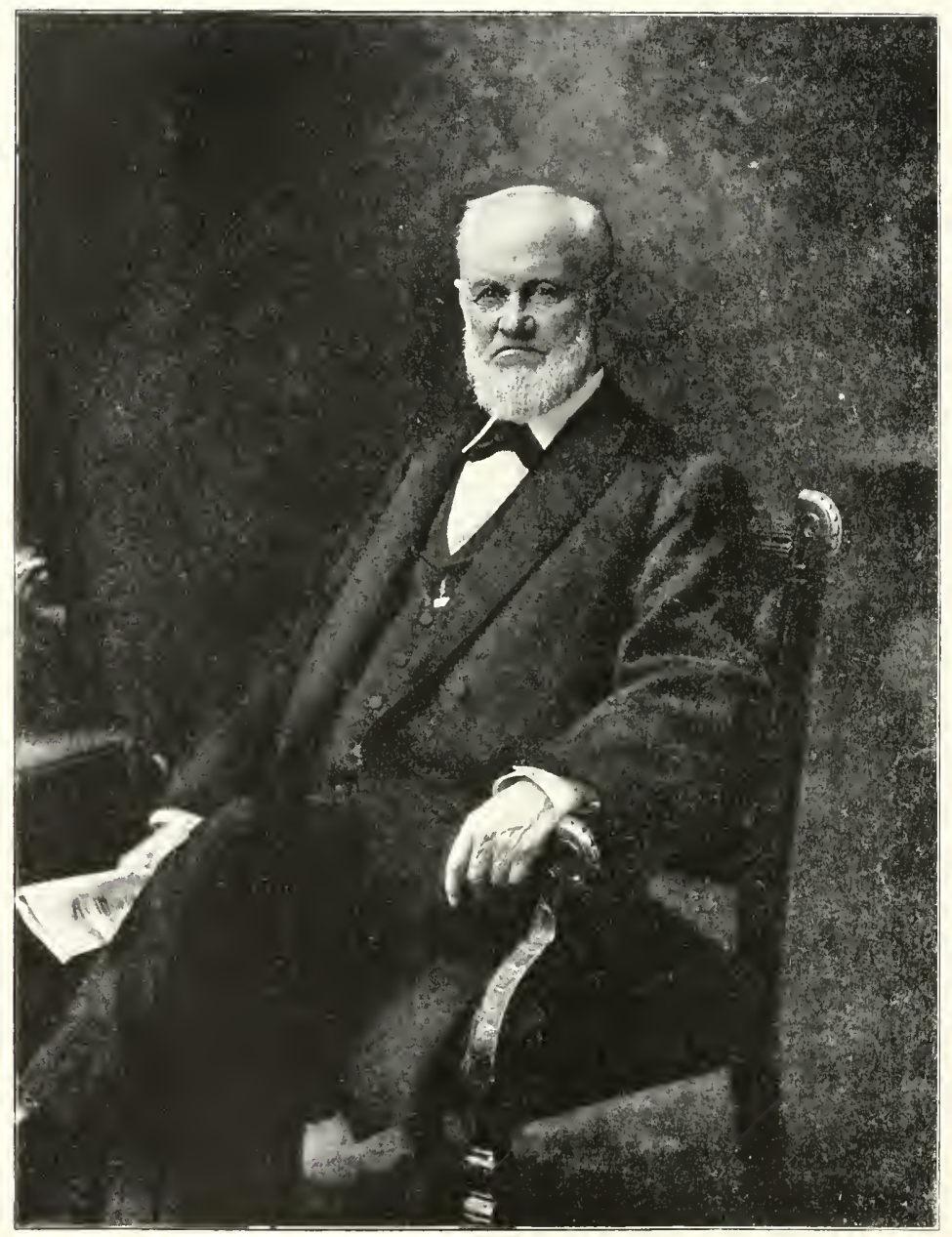

GEORGE A. BOARDMAN

It Eighty-one years of Age 
was the second. I used to enjoy the south, and California in winter where I spent twenty winters, but five years ago this winter, I lost ny wife and since I have remained at home in winter, my daughter who lived in Minneapolis, Mrs. 'Taylor, broke up housekeeping there, and has been with me ever since. Out of eleven children, she was the only daughter, the other ten were boys. I am, and have been very well, and last Sunday was my eighty-first birthday and according to the natural run of things I cannot expect to last very long. I begin to be quite a domestic man and like liome life and to be with my family and friends, and it is one of iny delights to gather the friends of my early days about me and discuss with them the happy events of by-gone days. My memory is good and faculties so keen that I can look over the picture of a long life like a panorama and live it over many times in a mental sense, and it pleases me to hear you expect you may come down east again next season, when I hope to see you and show you my museum of our local birds, ete., ete.

I have for several years every week or two, been writing a paper for our local papers, sometimes for the St. Croix Courier and then for the Calais Times. The last one has just come in which I will send you: About Growing Old.

My daughter says I have some photographs and will be glad to change with you. If they look too young, I will have some new ones taken.

I think the last time I saw you and Mis. Hallock was at the Smithsonian some time before our friend Prof. Baird died. I miss him very mnch and since, when I have been in Washington, made but a short stop. With many thanks for your kind letter and best regards to you and Mrs. Hallock,

Sincerely yours,

G. A. BoARDMaN.

Two brief notes which Mr. Boardman wrote for Forest and Stream, the first dated March 10, 1900 and the second, May 12 of the same year are here given :

I was pained to hear of the death of Mr. Risteen, and then so soon afterward of the death of Mr. Mather. I have known them 


\section{THE NATURALIST OF THE ST. CROIX}

both ever since they began to write such interesting articles for the papers. They have solved the great problem which we are all approaching, but leave pleasant memories behind and those who knew them will say their farewells with a deep sense of personal loss.

I see my subscription runs out the 1Sth. I enclose order for renewal. It is a magazine-paper of editorial genius and collects eritically and appetizingly the things sportsmen, naturalists and ornithologists most want to know - a storehouse of good reading, nice pictures and bright bits of news. I have read every number from the first and will be a life subseriber. But I am getting old now - in my eighty-third year - and am journeying into the shadow; the roar of the ultimate river is daily growing more distinct in my ear's.

The most important event of the year 1900 was the negotiations between Mr. Boardman and officials of the New Brunswick government for the transfer of Mr. Boardman's ornithological collection to that government. In May and also in July of that year Messrs. Todd, Tweedie, and Dunn visited Calais for that purpose and during the month of July an account of the birds and a catalogue of the eggs and nests in the museum were made. During the year Mr. Boardman spent much time in the museum and it was visited by more people than ever before in a single year. Its interest and value had become better known and among the visitors were scientific men from abroad, children from the schools and college students. Many articles were written that year by Mr. Boardman for the Calais and St. Stephen newspapers and on November 6 he records in his diary: "Voted for McKinley." On December 5 the diary says: "Mr. Dunn, Mr. Hill and Mr. Todd closed trade for my collection, payment to be made in one, two and three years, with interest." 


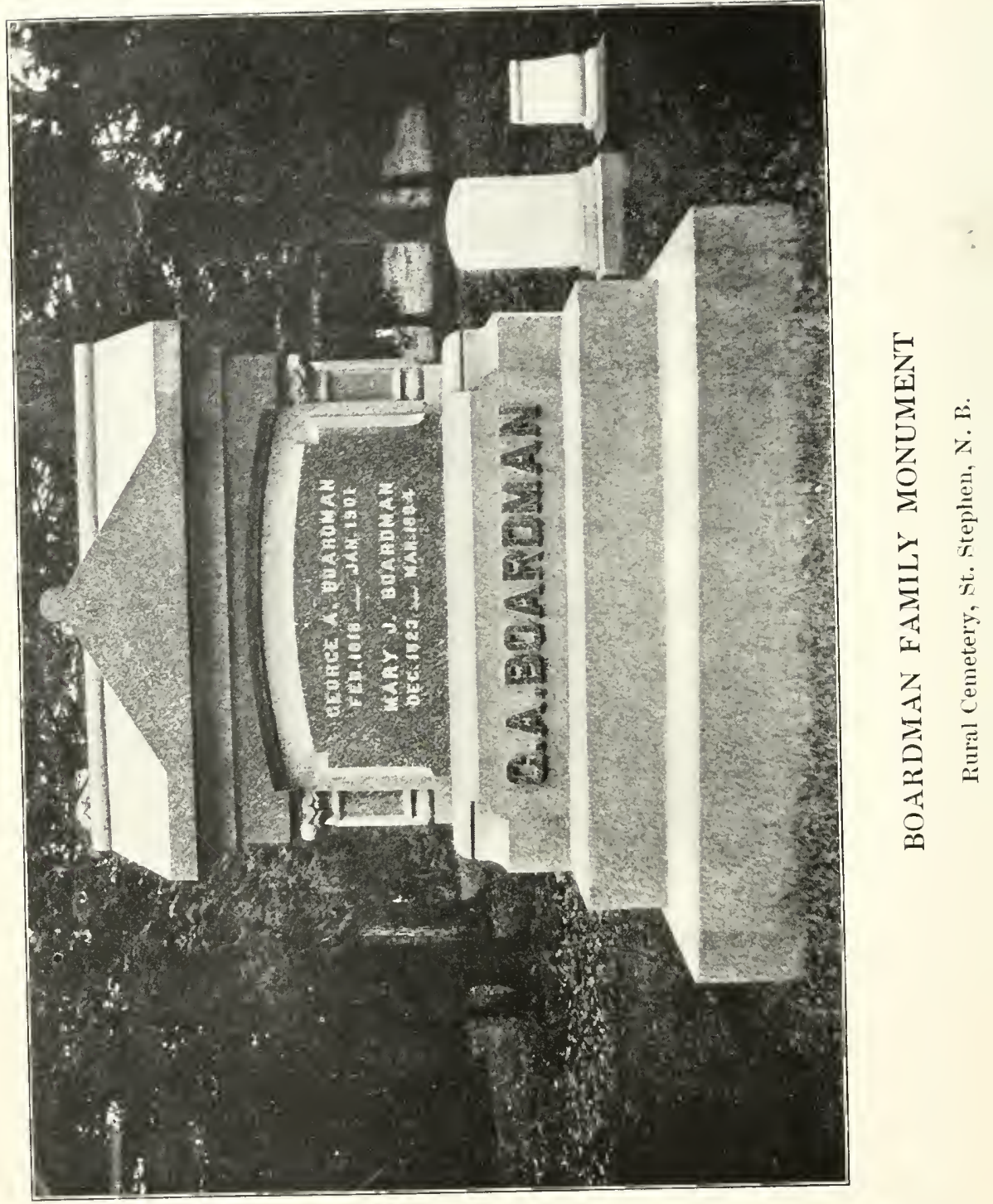


Monday, December 10, Mr. Boardman records: "I called Dr. Black; no appetite and don't sleep well nights." Dr Black called to see Mr. Boardman nearly every day during the remainder of the month and on December 31 he records: "Had lots of callers; Dr. Black called here twice."

But three entries appear in Mr. Boardman's diary for the year 1901. They are: "January 1 -Clear and fine; ther. 33 ; fine winter day; Dr. Black here; I had a bad day. January 2-Clear and cold; good many callers. January 3 -Ther. 5 below zero ; windy and a cold night." This was the last. The diary that had been kept daily with hardly an interruption for nearly forty-nine years had received its closing memoranda. Mr. Boardman died at 12.40 o'clock, Friday morning, January 11, 1901.

The funeral services were held from Mr. Boardman's late residence, No. 5 Lafayette street, Calais. They were attended by Rev. Dr. Charles G. McCully and Rev. Thomas D. McLean and the burial was in Rural Cemetery, St. Stephen, N. B. Four nephews of Mr. Boardman acted as pall-bearers, viz.: William F. Boardman, Henry B. Eaton, William F. Todd and Charles E. Boardman. 


\section{CHAPTER VI}

\section{THE BOARDMAN COLLECTION}

HE final disposition of his natural history collections
must have been a subject of much thought during the latter years of Mr. Boardman's life. It had been built up during many years of constant and loving effort and at great cost, while it had reached such proportions that it was one of the largest private collections of ornithology in the United States, embracing not only the birds of all parts of our own country but many of those of the West Indies, of South America, of Alaska, of Europe and of the more arctic regions of Greenland, Lapland and Russia. Most of the individual specimens had been obtained by himself and skinned and mounted by his own hands, or by exchange with the most eminent naturalists. $\mathrm{He}$ knew the particular history of each one. In his exchanges with scientific friends in this country and abroad he had obtained many rare specimens and was familiar with every bird, nest and egg in the collection. His love for it was great and each specimen and object had a dear and warm place in his heart. It can readily be understood, therefore, that its ultimate resting place was a matter about which Mr. Boardman had given 


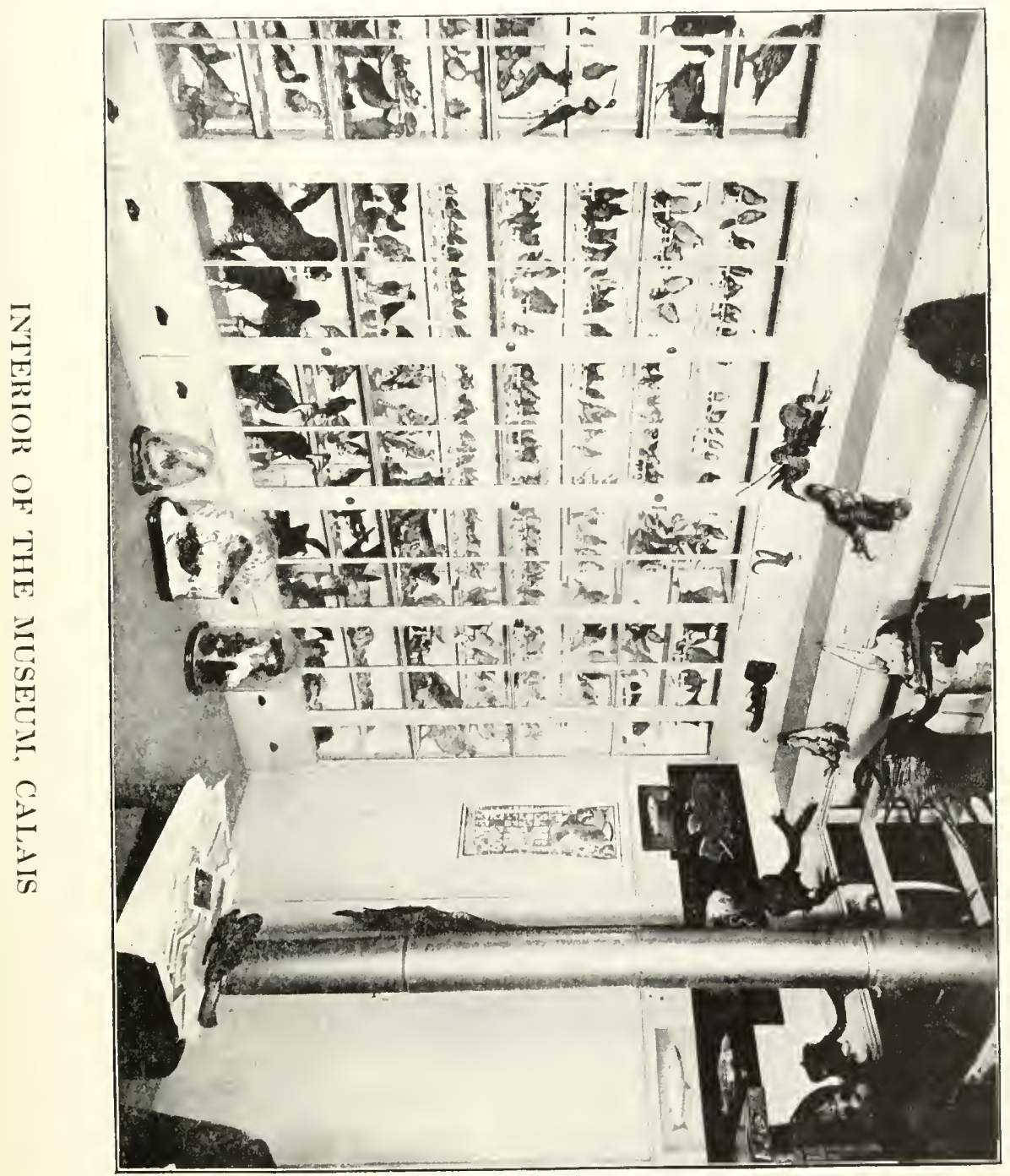



careful thought. He wanted it preserved in its entirety and kept in some place where it would serve the cause of science and be readily accessible to students of natural history. Hence the idea of its disposition excepting as a whole and to be in the custody of some public institution could not for a moment be thought of. It had been mentioned in some of the public journals that it was to go to Bowdoin College, where three of his sons had graduated and an institution which he loved. It is believed, however, that his first plan was for it to be kept in Calais. To be sure Calais was but a small city and was in no sense an educational or scientific centre; but its people were intelligent, many were wealthy and all held Mr. Boardman in the highest esteem. The town had long been his home, he had been successful in business there and it was in the St. Croix valley where the larger part of the collection had been made. Next to Calais, Mr. Boardman no doubt hoped that it might go to some institution in the Province of New Brunswick.

During the summer of 1882 , while Mr. Boardman was in Minneapolis, an effort was made by the Portland Society of Natural History to obtain his collection as it had come to the knowledge of the society that Mr. Boardman might make his future home in the west. On April 14, 1882, Mr. N. Clifford Brown, curator of ornithology of that society addressed a letter to Mr. Boardman saying :

Our Society has recently learned of your intended removal from Calais and the consequent probability that your well-known superb collection of Miaine birds may be obtained by purchase. I hardly necd say that we would greatly like to see this collection in our own eabinets. You will doubtless agree that no more 
suitable resting-place for it could be found. Being the largest if not the only incorporated society in the state, the Portland Society of Natural History feels a peculiar interest in so fine a representative collection as your own of Maine zoology.

I am instructed by our president to inquire whether we may hope to seenre this collection, provided that the price at which you value it is not beyond on means; also, if it is indeed to be sold, to request you to state the amount you wish to receive for it.

Several letters from Mr. Brown have been found among Mr. Boardman's MSS., but no formal action was ever taken by the Portland society for the purchase of the collection so far as appears from papers that have been accessible.

In the year 1893, when plans for the erection of the public library building in Calais were being considered, Mr. Boardman made a free tender of his entire collection to the trustees of the library in behalf of the city, if they would make the building sufficiently large-by the addition of a second story where a hall conld be provided for the housing of the collection, or by some other enlargement which would give it sufficient accommodation. The answer of the trustees was that they had their plans, contracts and money for the erection of the building so arranged that they could not well make the necessary changes which would be needed for the suitable display of the collection; they did not know where to obtain the additional funds that would be required to erect the larger building and so the proffered offer was not accepted. About this time it was more than half intimated that one of the wealthy residents of Calais or St. Stephen had it in mind to erect a handsome building in the public park of Calais, which is opposite Mr. 



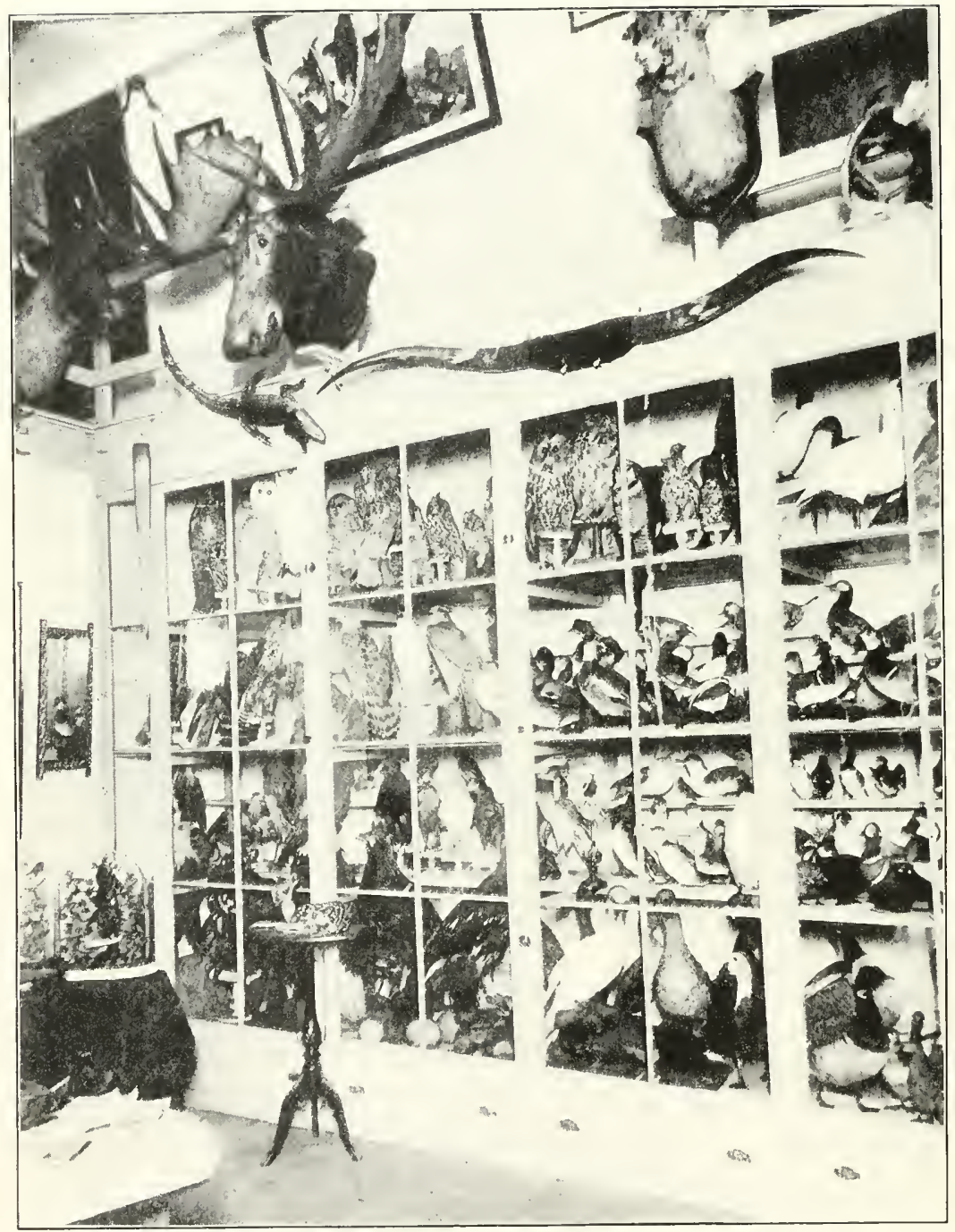

INTERIOR OF THE MUSEUM, CALAIS 
Boardman's residence, for the purpose of lousing his collection, but such a plan was never made effective.

While at the time this offer was made to the city through the library trustees, Mr. Boardman was much disappointed, if, indeed, he was not displeased, at its rejection - the gift was one of so marked a cliaracter and was so generous - he was afterward glad that it had not been accepted. 'This was because he realized the city could not afford to employ a proper person to take charge of the collection. In such want of care he foresaw that the collection might suffer from neglect, that the most valuable specimens might disappear and that in consequence the collection would lose its value and be of little use to science.

It was at this juncture that preliminary steps were taken toward transferring the collection to the Provincial Government of New Brunswick. It had been understood that next to the city of Calais possessing it Mr. Boardman had hinself expressed a wish that it might finally go to New Brunswick. The collection represented the fauna of the St. Croix valley, which was as distinctively Canadian as it was American; it had been largely made up of specimens from the territory on both sides of the St. Croix river and the natural home of the collection should clearly be in the vicinity of the place where it was made. Hon. William F. Todd and Hon. George F. Hill, both of St. Stephen, N. B., and both members of the Provincial Parliament were interested in having the collection retained in New Brunswick and their efforts had much to do in influencing the government to its purchase.

Speaking of the transfer of the Boardman collection to 
the New Brunswick government The Calais Times of December 27, 1900, said: "It is a great acquisition to the government crown land office. New Brunswick's gain is an irremediable loss to Maine. A source of keen regret is the fact that Mr. Boardman once offered this priceless collection as a gift to the city of Calais on conditions that could have been met with ease; but his offer was not accepted. It is too late now and the poignancy of the irreparable loss will long linger in the minds of all intelligent people who dwell in the towns on the Maine side of the St. Croix."

From Mr. Boardman's diary it appears that on May 30,1900 , the first effort toward making an inventory of the contents of the museum with a view to its sale was made. On July 4 of the same year the Provincial Premier, Hon. L. J. Tweedie and the Surveyor-General, Hon. A. T. Dunn of Fredericton, visited Calais and made a thorough examination of the entire collection. The result of this visit was that $\mathrm{Mr}$. Boardman at once commenced to take an account of the specimens in the museum which work occupied him until July 31 , while various entries in the diary between those dates tell of the progress of the work. Finally, on December 8, 1900, the sale of the entire collection was made in accordance with the following indenture :

Memorandum of Agreement, made this Eighth day of December, A. D. 1900, between George A. Boardman of Calais, in the State of Maine, one of the United States of America, Gentleman, of the first part, and Her Majesty the Queen, represented herein by the Honourable Albert 'I'. Dunn, Surveyor General, of the second part; -

Witnesseth, First : - That the said George A. Boardman hereby sells to Her Majesty the whole collection of birds, eggs, 
heads of animals, horns, \&c., all as contained in the building in Calais, used for the said eolleetion and specified and described in a list furnished to the said surveyor-general, for the sum of said amount to be paid, as hereinafter provided for.

Second:- Her Majesty herehy agrees to pay to the said George A. Boardman, for the said collection, the said sum of in three equal payments in the manner and at the times following, viz: the first one-third portion thereof immediately after the elose of the next ensning session of the Legislative Assembly of New Brunswick, the second one-third portion thereof immediately after the close of the Legislative Assembly to be held in the Year of our Lord, one thousand nine hundred and two, and the last one-third portion of said payment immediately after the close of the Legislative Assembly which will be held in the Year of om Lord one thousand nine hundred and three, the last two payments to bear interest at the rate of five per cent. per annum, from the time of delivery of the said collection to the said surveyor-general, or his agent.

Third:- It is hereby understood and agreed that the said surveyor-general, on behalf of Her Majesty, may take delivery of the said collection immediately after the execution of these presents, or at such time as may be most convenient to him.

It is also understood that if the surveyor-general so desires, payments may be made at any time before the times above provided for.

In witness whereof the said party hereto of the first part and the said surveyor-general, on behalf of Her Majesty, have hereunto set their hands and seals the day and year first above written.

Signed, Sealed and Delivered ? in presence of

(Signed) Geo. A. Boardian.

(Signed) A. 'T' DUNN,

(Signed) WM. F. TODD.

Surveyor General.

Witness to signature of

A. T. DUNN,

(Signed) W. P. Flewelling.

From the above indenture has been omitted the sum paid by the government of New Brunswick for the collection. But it may be mentioned that the same was 


\section{4 'THE NA'TURAIIST OF THE S'T. CROIX}

appraised by expert scientists as to its commercial cash value and in accordance with Mr. Boardman's own wish one half the amount was discounted by which he gave the Province several thousand dollars.

At the time this document was drawn and signed Mr. Boardman was not at all well. From that date he was almost daily visited by his regular physician, Dr. W. 'T. Black and frequent entries in the diary made the record : "Had a bad day;" "had a bad night-did not sleep well," etc. By the terms of the sale the collection was liable to be immediately removed, but as Mr. Boardman rapidly grew worse, Mr. Todd, who was the agent of the Provincial government in charge of its transportation, wisely postponed doing so. It was very satisfactory and comforting to Mr. Boardman to know that his loved collection was not to be removed during his life and that finally it was to go to a government which would house it in a splendid manner, that it was to have appropriate care and always be open to the public and to the free use of scientific students.

The preliminary contract for the transfer of the collection, dated December 8, 1900, was ratified by the Provincial Parliament by an act passed April 3, 1901. This act is Cliapter XX of First Edward VII, and is as follows :

An Act relating to the Boardman Collection of Birds and Animals. Sec.

1. Preamble setting ont contract. Gov-

ernor in Council authorized to make payments as provided by contract out of current revenues. Sec.

2. Duplicates may be placed in $1 \mathrm{~m}$ perial Institute in London; provision for preserving collection. Passed 3d April, 1901.

Whereas by memorandum of agreement made on the eighth day of December, A.D. 1900, between George A. Boardman of Calais, in the State of Maine, of the first part, and Her Majesty the Queen, represented therein by the Honorable the SurveyorGeneral, of the second part, it was witnessed that the said 



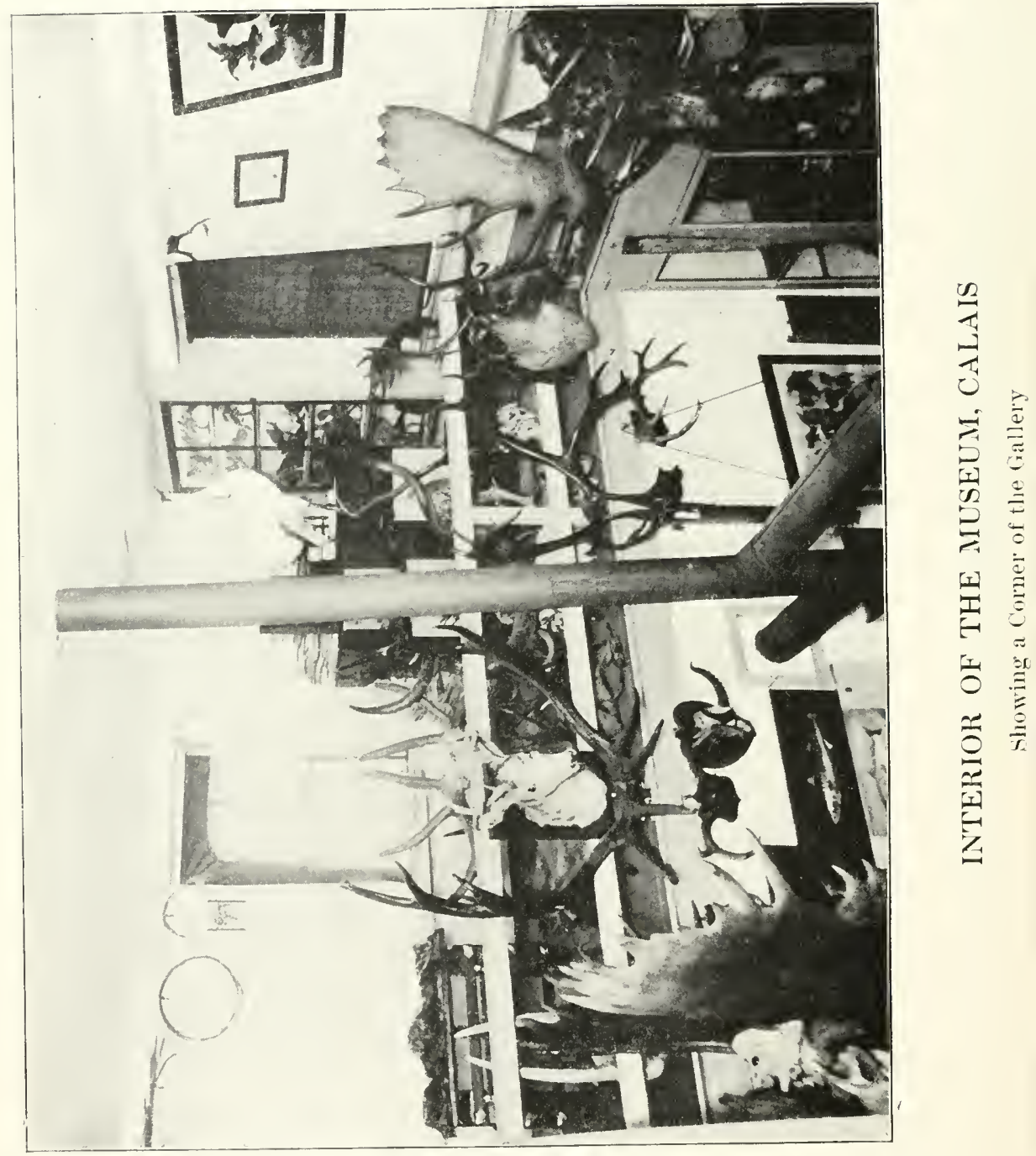


George A. Boardman thereby sold to Her Majesty the whole collection of birds, eggs, heads of animals, horns, etc., all as contained in the building in Calais, used for the sair collection, and specified and described in a list furnished to the said SurveyorGeneral, for the sum of ___ _ which amount was to be paid as follows, namely: a first one-third portion thereof immediately after the close of the present Session of the Legislative Assembly of the Province, the second one-third portion thereof immediately after the close of the Legislative Assembly to be held in the year of our Lord, one thousand nine hundred and two, and the last one-third portion of said payment immediately after the elose of the Legislative $A$ ssembly which will be held in the year of our Lord one thousand nine hundred and three; the said last two payments to bear interest at the rate of five per cent. per annum from the time of delivery of the said collection to the said Surveyor-General, or his agent; and it is desirable to make provision for the payment of the said amounts, and also to make other provisions as hereinafter enacted;

Be it therefore enacted by the Lientenant-Governor and Legislative Assembly as follows:-

1. The Iieutenant-Governor in Council is hereby authorized to pay the said amounts in the manner and at the times specitied in the said agreement, the same to be paid out of the current revenues of the Province.

2. The Lieutenant-Governor in Council is hereby authorized to place such portion of the said collection, being duplicates, as he may deem advisable, in the Imperial Institute in Loudon, and also to make necessary provision for the placing and keeping of the remainder of said collection within the Province, and for that purpose may expend a sum not exceeding fifteen hundred dollars, for the erection and equipment of a suitable building, or the equipment of a suitable room therefor; the cost of such building to be paid out of the current revenues of the Province.

Soon after the death of Mr. Boardman the collection was packed and shipped to Fredericton, N. B., under direction of Hon. William F. Todd of the Provincial 
Parliament. It was comprised in seventy-four boxes which included the birds, nests, and eggs, together with the animals, skulls, heads, horns, corals, casts of fishes and other natural history specimens which made up the collection. The collection is now installed in the old supreme court room of the Parliament House at Fredericton, N. B. This room is twenty-eight by thirty-three feet and is ratlier imperfectly lighted. The cases, which are quite tall, so obstruct the light that it is impossible to obtain a satisfactory view of the interior, but the accompanying plan will give a good idea of the arrangement of the room while the plate shows the beautiful Government House in which the collection is deposited.

There are seven large cases in the room, each of which has several shelves, together with two octagon cases which are placed around pillars which support the ceiling. Against the wall opposite from the entrance to the room out of the main hall is the original case-marked Awhich was in Mr. Boardman's Milltown, N. B., residence and in his Calais museum, while over it upon the wall in large letters is a tablet reading: The Boardman Collection. This original case has in it from 140 to 150 species of song birds. Around the walls of the room are eleven cases, in an inclined position, for the nests and eggs, while upon the walls in various places are disposed the casts and paintings of fish, with heads and horns of animals. There is a fine pair of elk horns from Oregon and a pair of moose horns from Maine, the latter of which spread fifty-six inches, with eighteen points on each horn, having very wide palmations. It is one of the most elegant pairs of moose horns ever taken in this State. The mounted warblers are in the centre octagon 


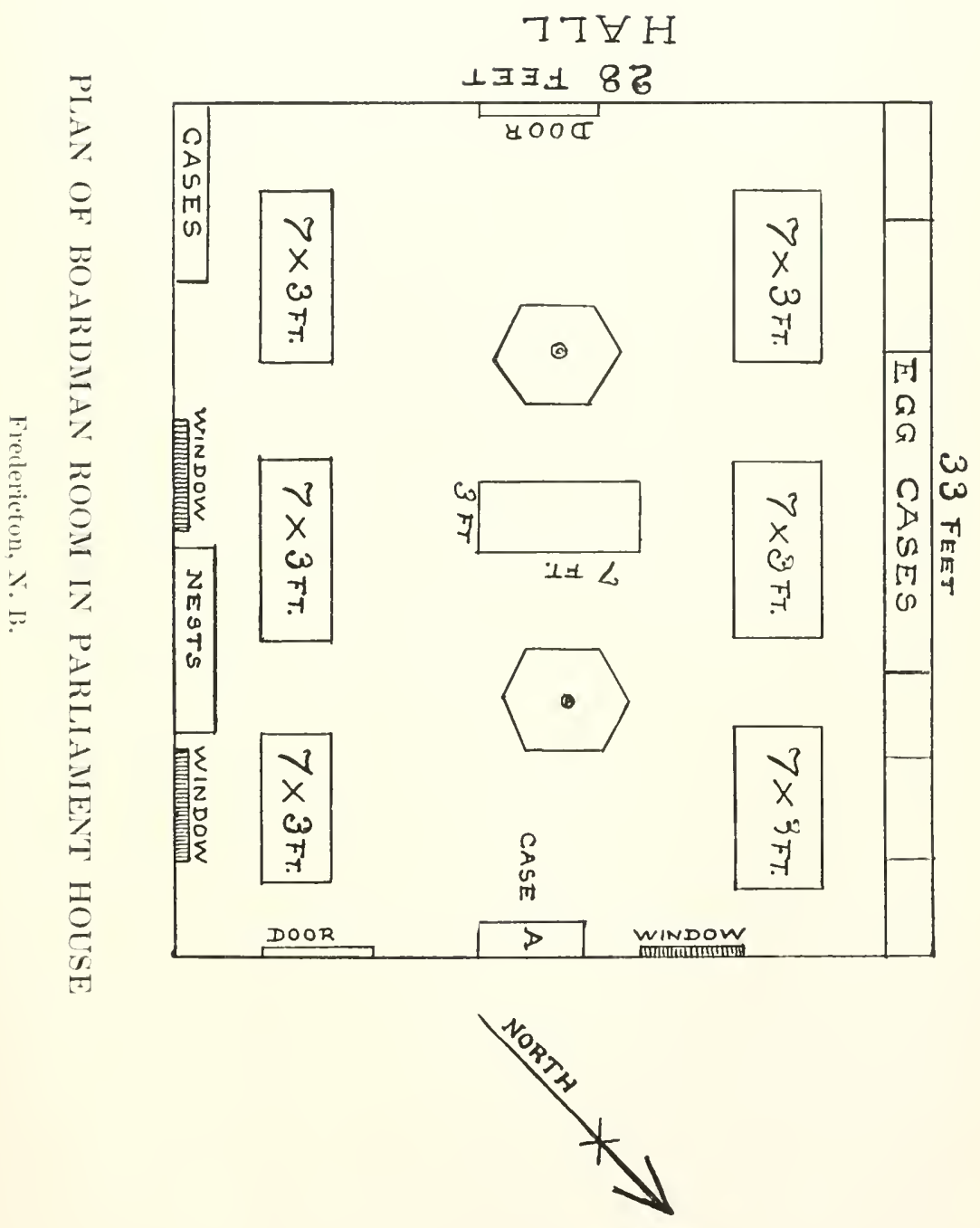



cases; there are three cases of water birds, with four smaller cases, not shown in the plan, the latter just as taken from Mr. Boardman's museum. The mounted bircls, skins, animals, eggs, nests and other specimens all have attached to then the original labels written and numbered by Mr. Boardnan.

As installed in its present home the collection was arranged by Mr. John F. Rogers who was for a number of years principal of the model school in connection with the Provincial Normal School at Fredericton. He was fond of natural history and had made quite a study of the habits of birds and animals and his work in setting up the collection was very satisfactory. It will be of interest to the friends of science to know that under section two of Act XX of First Edward VII, it is the design of the Provincial Government to erect a special building for the housing of the Boardman collection. It is under the custody of the Hon. W. P. Flewelling, Deputy Surveyor General, Crown Lands Department, Province of New Brunswick.

The following account of the collection, from the pen of Mr. Charles Hallock, appeared in Forest and Stream for February 2, 1901 :

Henceforth the unique and valuable museum collection of the late George A. Boardman who passed away so recently at his quiet home in Calais, Me., will be located and housed at Fredericton, N. B., in one of the best Government buildings, where it will occupy a conspicuous place and receive the care and attention which it deserves. 'The Hon. Wm. F. Todd, a member of the Provincial Government, who is a nephew of Mr. Boardman, has charge of the removal and installation of the collection. Indeed, he was about to ship it when Mr. Boardman was taken ill, bnt considerately postponed doing so, and conseqnently the ingathering of this eminent naturalist remained with him to the last, much 


\section{8}

to his heart's comfort and content, for the momentary parting with it at such a juncture would have been like speaking a final farewell to his dearest and most intimate companions and friends.

What a happy relief it must have been to his mind to have this collection so opportunely and desirably disposed of. Not less will his New Brunswick friends delight to do him honor. My own choice would have selected Fredericton next to Calais as his beneficiary. And Canadians are warm hearted, honest, faithful and unpretentious people, as I have always found them. Almost every week I receive epistolary testimony from some of them to this effect.

Perhaps it is better that Calais did not receive the gift. Years ago Mr. Boardman gave me his confidence, to a certain extent, as to the want of appreciation of his home people ("a prophet is not without honor except in his own country"), the municipality deelining his repeated overtures, first, on the plea that the city had no suitable building for the collection, and afterwards declining to erect one. And it serves the corporation right to be left out, though the body of the town's people will sympathize with us all in the regret that the home site and the center of his life work could not have been selected and appropriated for this distinguished monument of his labors. It is a grand donation: It represents so much, not only of the local fauna of that interesting region, but so much persevering study, devotion and effort of pursuit.

I have not been able to obtain a classified memorandum of the G. A. Boardman collection, but I have been told by the proprietor that there were more than 3,000 birds and perhaps half that number of manmals and miscellaneous subjects, including many marine curiosities. The world of science cannot well spare such contributors as George A. Boardman and George N. Lawrence; both of them gone within a decade.

The city of Fredericton, the home of the Boardman collection, is the capital of New Brunswick and is situated on a beautiful intervale on the west side of the St. John river, about eighty miles from its mouth, and 



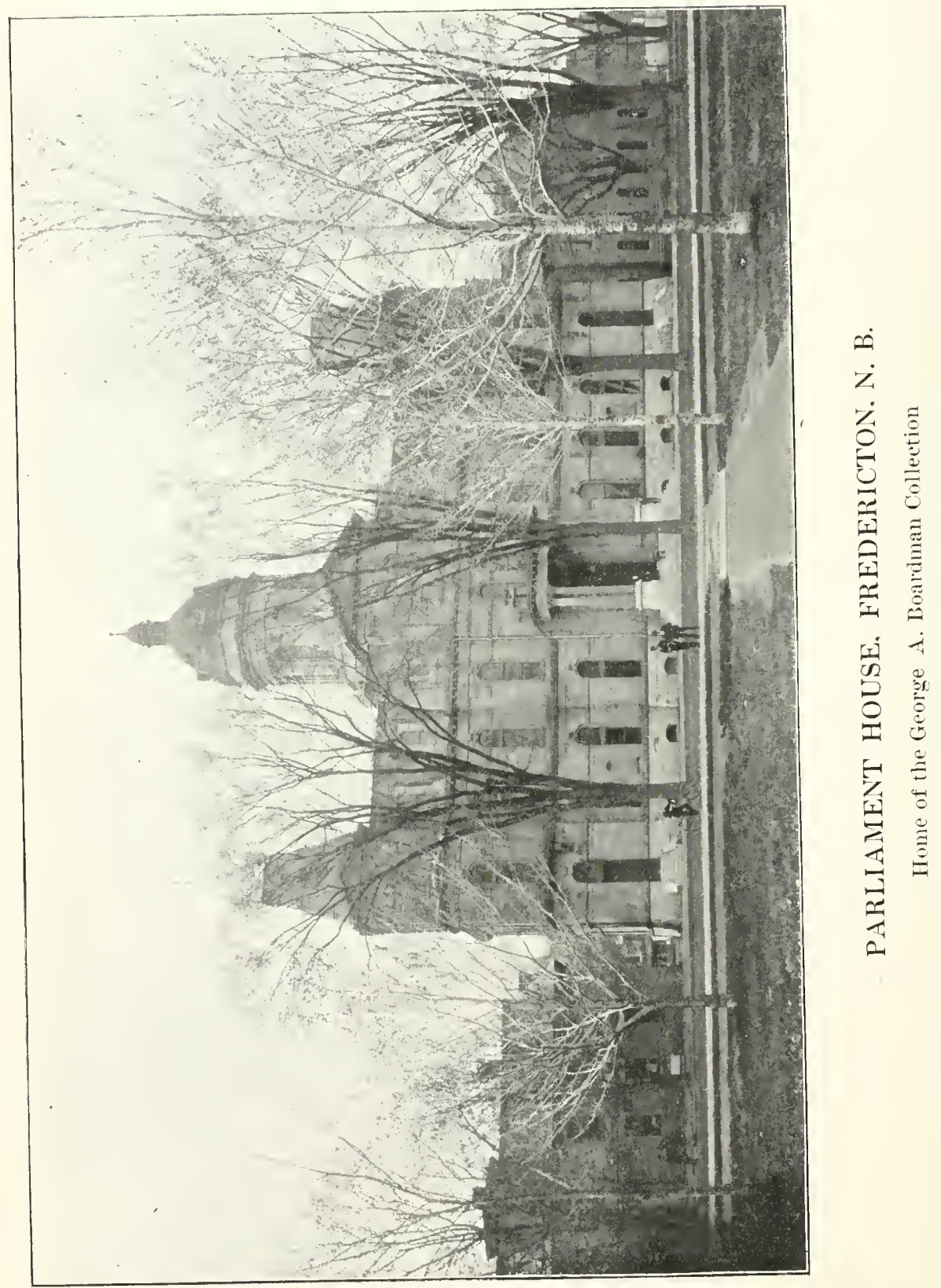


twenty-two miles by rail from Fredericton Junction on the Canadian Pacific Railroad. Its population is something over 7,000, and its public buildings include the Parliament House and public offices of the Provincial government; eight churches; an Episcopal cathedral; a normal school for the training of teachers; the Victoria Hospital; city hall, and the University of New Brunswick. In the assembly chamber of the Parliament House are many historic portraits including those of George III. and of his amiable consort, Queen Charlotte, painted by Sir Joshua Reynolds, with those of Lord Slieffield and of Lord Glenelg. The Legislative Library embraces 14,000 volumes, one of the most highly prized works which it contains being one of the original folio sets of Audubon's Birds of America which formerly belonged to King Louis Philippe of France, father of the Duke of Orleans, now valued at $\$ 15,000$. As Mr. Boardman often visited Fredericton it is likely he knew of its possession by the Legislative Library and wanted his own birds to have a home with that magnificent work of Audubon's. It is certainly a happy coincidence that the two are housed in the same fine building and it would have been a dear satisfaction to Mr. Boardman had he known his collection was to have the company of Audubon's splendid work. 


\section{CHAPTER VII}

\section{SOME SCIENTIFIC RESULTS}

HE ornithological museum created by Mr. Boardinan
will always remain the great triumph of his life as a naturalist. It is indeed a sufficient monument to the exactness of his knowledge in that branch of science to which he was devoted, to his love for natural history, to his application and industry in its study throughout a long period. Other men devoted to science have left worthy memorials of their life-work in other ways voluminous treatises, exact and learned monographs, published works which have ranked as authoritative in the great libraries of the world. It is Mr. Boardman's monument to have left to science one of the largest and most interesting collections in ornithology and natural history ever gathered by a private individual in this country, representing a life-time of active study and preserving to students of ornithology a collection showing the almost complete fauna of eastern North America. While this is indeed abundant fame for one individual much can be said for Mr. Boardman's contributions to the literature of ornitlology and general natural history.

It may be mentioned at the outset of such summary of results that Mr. Boardman was not in earlier life much 
given to literary composition. He was so intensely engrossed in business and, after business cares had been largely given over to others, was so devoted to travel and collecting, making brief notes of his specimens and carrying on an extensive correspondence with naturalists, that he had little time for finished composition, or placing in elaborate form the results of his observations and studies. It was rather his work to assist others, to study points of difference, to note peculiarities in species, to suggest lines of inquiry to other workers. When the first results of his studies were publislied through the Boston Society of Natural History as early as 1862, it was done at the solicitation of Prof. A. E. Verrill who edited the list of birds then printed, because, as he says, "Mr. Boardman could not attend to it himself." And so it was for many years. He was so much engaged in collecting and in field study that he had no time for extended literary composition. It was only in late life, after his ornithological field had been thoroughly explored that he found time for writing those delightful autobiograplical and historical sketches which for two or three years appeared regularly in the Calais and St. Stephen newspapers. These show what interesting chapters he could have written on the fauna of the St. Croix, based upon his own collections and field studies, had he had the opportunity and set himself about it earlier in life.

Mr. Boardman's habits of observation were very acute and his published statements noted for their accuracy and correctness. If there was anything which he could not tolerate it was a hasty, imperfect or misleading statement regarding natural history in any published work. Tliese 
gave him untold annoyance. When a certain work on the birds of New England and some of the adjacent states was published about 1867, after he had examined it he laid it down, exclaiming: "Oh! the errors, the errors!" - and seldom looked at it afterward although some of the errors were corrected in subsequent editions.

One of his favorite literary exercises was the answering of puzzling questions in natural history, asked by readers of the journals and magazines. In one of the earlier volumes of Forest and Stream an inquiry appeared from a correspondent wishing to know who that man was way down east who settled all the disputed points in ornithology - " whether the woodcock whistled with his bill or wing? what was the bird known as fool-partridge in the west? why was not the western black duck good to eat?" etc. He took delight in answering all such questions. It was done in few lines, yet with great clearness and his answers were always the final word upon the subject. The editor of Forest and Stream, in the issue for Jannary 26, 1901, says that one of the last letters received from Mr. Boardman, only a short time before his death, was written in kindly response to the inquiry of a correspondent if he knew of a single authentic instance of the taking of the panther in Maine. His reply was in the negative and he added: "I have for fifty years been looking after the skull of a panther that was killed in this part of the state for my museum and have not been able to get one."

The correctness of Mr. Boardman's statements and opinions upon subjects about which he was acquainted or in which he had made studies may well be illustrated by his views regarding the introduction and naturalization of European game birds into Maine. In 1894-1895 
officers of the Maine Ganne and Protective Association were engaged in introducing into the state the Messina quail, Coturnix communis, the common migratory quail of Enrope, as well as the Capercailzie or Wood-grouse, the largest of the gallinaceous birds of Europe.

In one of the local newspapers Mr. Boardman had questioned the action of the association in inducing the State Legislature to make an appropriation for the purpose of introducing these birds, on the ground that it would be a waste of effort and funds. To this Mr. Edward G. Gay, president of the association, replied in a lengthy article in the Plinlips Phonograph of February 27, 1895. The real substance of Mr. Boardman's statement was simply that the scheme would not be a success, the birds would not become naturalized and the matter would end in disappointment. Mr. Gay's criticism of Mr. Boardman's opinion was in these words:

The Association has been guided by some of the best and most noted game bird experts of our own state, all sections of this union and of foreign countries, with all of whom I have been in constant correspondence. The practical present day experience of these men ought certainly to count for as much as the theories of naturalists whose knowledge of what they are writing about is gleaned wholly from pedantic books of reference. I.et me say to Mr. Boardman and to your readers that I have not spent inndreds of dollars of my own money and months of my time, nor lave the other friends of this beneficent movement also sacrificed money and time to promote this object without kuowing what we were doing and the people of this state will have no reason to regret any action the legislature of Maine may take iu earrying to a suceessful conclusion the work already so auspiciously begun.

It is sufficient answer to this criticism that Mr. Boardman's opinion was correct. Many of the quail were 


\section{THE NATURALIST OF' THE ST. CROIX}

liberated near Calais, but good hunters and woodsmen say they were never seen after the first or second season. Some bred but none were ever seen afterward. The best scientific authorities upon this point say: "This quail - the Messina - has several times been imported into the United States, but has failed thus far to become naturalized."

In the Bulletin of the Nuttall Ornithological Club, Volume VI., page 126, January, 1880, in a list of birds of Long Island by De L. Berier, Fort Hamilton, L. I., occurs this note: "Falco gyrfalco absoletus; Labrador gyrfalcon. Mr. J. Wallace of New York informs me that a fine specimen of this bird, killed in the fall, two or three years ago, on the north shore of Long Island in Queens county, passed through his hands. It is now in the collection of Mr. George A. Boardman." Without doubt this is the falcon which Mr. Boardman saw a hunter bring into the market in New York, when he was on one of his visits to that city and referred to in a note found among his papers. The note says Mr. Boardman bought the bird, had John Wallace skin it and took it to Washington with him. When in New York he generally went around to the markets to see what he could find that was new and always took the rare or unusual specimens to Washington for identification. One of these was a strange duck which Mr. Boardman purchased at a market in New York in 1871, which he had Mr. Wallace skin. This was taken to Washington for identification and caused something of a puzzle to the Smithsonian experts, by whom it was at first thought to be a cross but afterward proved to be the Crested Duck of Europe, according to a letter from Prof. Baird dated at 
Woods Holl, June 22, 1871. These incidents show how accurate Mr. Boardman was in his knowledge and how quick he was to detect anything new or to notice the slight variations in species which an ordinary sportsman would pass unnoticed.

One of Mr. Boardman's sons tells the following interesting incident: "Many years ago I was with my father and Prof. Baird in the garden at Milltown, N. B., when father said: 'I had a black buzzard, professor, the other day, killed near here.' Prof Baird replied, 'Oh no, Mr. Boardman, you must be mistaken; they seldom come as far north as Washington. It must have been a turkey buzzard.' Father replied: 'I know a black buzzard as well as I know a crow.' 'The professor, however, was not satisfied. In a few minutes a man drove into the yard with a box. I opened it, took out the bird and carried it around where they were talking. Father said: 'Professor, what do you call that?' He replied, 'a black buzzard.' Then father took the bird to his bird house and the professor said to me: 'I find your father is always correct in all our disputes about native birds. When we read the manuscript of our book at Peaks Island (Baird, Brewer and Ridgway's History of North American Birds), your father did not agree with Dr. Brewer in many of his statements, so I decided with your father. Dr. Brewer has great knowledge of birds and eggs and has long been a student in that line, but your father's knowledge came from association with the birds and the studies of their habits in the woods and his observations were correct.'"

Pioneer field ornithologist in Maine that he was, Mr. Boardman made his studies and recorded his observations upon the birds of eastern North America before the 


\section{6 'THE NATURALIST OF THE ST. CROIX}

present school of ornithologists had begun their work and all recent writers have been indebted to his results for much of their knowledge of Maine birds. He was the first to describe many species and found the first nests and recorded the nesting habits of many birds then new to science. One of these was that of the large Slieldrake; another that of the Canada Jay; another that of the Crossbill; another that of the American Merganser. Winfred A. Stearns, in his New England Bird Life, acknowledges his indebtedness to $\mathrm{Mr}$. Boardman for a description of the nest of the Canada Jay, while Mr. George Bird Grinnell, in his American Duck Shooting, New York, 1901, makes no less than six acknowledgments to Mr. Boardman for original information and prefaces his account of the nesting habits of the American Merganser, pages 227-228, by saying: "Definite information as to the breeding habits of the American Merganser were first given by Mr. George A. Boardman of Calais, Maine, to whom ornithology owes so much." The entire account appears in his paper on Tree Nesting Ducks, in this volume.

Writing to Mr. Boardinan under date of December 2, 1862, Prof. Baird says: "I had not before known of the occurrence of the banded three-toed woodpecker so far south. Try and get us a good specimen." This and similar statements found in his correspondence show how constantly Mr. Boardman was finding out and recording new things about birds which information he was freely giving to the leading naturalists of the country as his contribution to science, seldom wishing to be known as the first to establish such facts if only science in general received the benefit of the same. Many instances 
in the letters of Prof. Baird might be quoted to show the esteem in which,Mr. Boardnan's acquirements in ornithology were held by that great naturalist. Writing to him on November 15, 1865, Prof. Baird says: "We were advised of thirty-trwo boxes of arctic eggs, etc., this fall - they will not be here, however, till May or June, not getting to St. Paul before winter. In the lot are 1200 more Ptarmigan eggs; I think when they come I will send for you to help catalogue them. A correspondent near Lake Winnipeg advises of eggs of Franklin's gull, crested grebe, red head cluck, etc., all new to us." Again writing Mr. Boardman September 26, 1877, Prof. Baird says: "The discovery of a Pine Grosbeak on Mt. Victor is a curious fact. Can you not arrange to have some one go there in the spring after the eggs?"' These instances show the confidence placed in Mr. Boardman by America's great ornithologist.

All writers upon New England bird life and generally upon the birds of eastern North America have been generous in their acknowledgments to Mr. Boardman to whom they have been under obligation for many facts stated by no previous naturalist. Dr. T. M. Brewer, writing of Lagopus albus, the Willow Ptarmigan, in Bulletin of the Nuttall Ornithological Club, Vol. II., page 46, says the statement he has made "rests on the high authority of Mr. G. A. Boardman." Regarding this species Mr. Stearns says in New England Bird Life, Part II., page 145: "Mr. G. A. Boardman assures me that he has been unable to satisfy himself that this Ptarmigan has ever been known to occur in New England."

William Dutcher, in his monograph on The Labrador Duck, in The Auk, Vol. VIII., page 201, April, 1891, 


\section{THE NATURALIST OF THE ST. CROIX}

makes no less than seven quotations from notes by Mr. Boardman, who says the last one of this species he knows to have been taken at Grand Manan was shot in April, 1871. "I sent the skin to John Wallace of New York to be mounted for Prof. S. F. Baird of the Smithsonian Institution. Not knowing its value, Wallace let some one get the skin from him and it was thus lost to the Smithsonian as he could not tell who had it." Writing to Mr. Dutcher, October 29, 1890, Mr. Boardman says :

"I began to collect birds about fifty years ago and wanted to get a pair of each species - I did not care for more. The Labrador Duck I procured without much trouble and if I had any duplicates sent to me I did not save them any more than I should have saved duplicates of Scoters or Old Squaws. I have no doubt I may have had others. I had shooters all about the coast of Grand Manan and Bay of Fundy sending me anything new or odd. Anything they sent me that I already had mounted generally went to the manure heap. About twenty years since, Messrs. John G. Bell and D. G. Elliot of New York wrote to me to try and get them some Labrador Ducks. I wrote to all my collectors, but the ducks had all gone. It seems very strange that such a bird should become extinct as it was a good flier."

Prof. Ora W. Knight, in his Birds of Maine, published in 1897, says: "George A. Boardman of Calais has observed and taken two hundred and fifty-seven species within Washington county. His list is copiously annotated and is the result of long years of careful observation."

Baird, Brewer and Ridgway who published their History of North American Birds between 1874 and 1884, 
refer frequently to the observations of Mr. Boardman and quote from information specially furnished by him. Upon page after page throughout the five noble volumes of that work acknowledgments are given to Mr. Boardman. Mr. Cliarles Hallock, in his Camp Life in Florida, gives acknowledgment to Mr. Boardman as " that well-known student of natural history whose writings have special value to the scientist." Other writers who have benefited fron his studies and given due credit are Elliott Cones, D. H. Minot, Robert Ridgway, Everett Smith, E. A. Samuels, Ruthven Deane, N. Clifford Brown, J. A. Allen, A. E. Verrill and Charles Hallock, as well as the lesser known authors who have written about New England birds.

In volume third of the American Naturalist, page 837 - September, 1869 - Mr. Boardman has an interesting note on the collection and care of birds' eggs. He says : In collecting eggs the utmost importance is to be placed upon the proper identification of the specimens. To every bird's leg attach a label noting sex, date of capture and locality. Blow the eggs with a blow-pipe. Make but one hole and that on the side. Above the hole write the initials of the collector and under it the number, also the Baird Smithsonian number. All the eggs in one nest should have the same number. Suppose I take my first nest, Canada Jay, March 15, with three eggs. I mark all three eggs, say No. 5, and keep a small note book, properly ruled, in which I record the date, name of bird and number of eggs, number of egg in Baird list, and remarks, as: "Taken by myself (or as the case may be) out of a small spruce, six feet from the ground, old bird shot," etc. A printed label with the 


\section{THE NATURALIST OF THE ST. CROIX}

name of the bird looks very neatly. In the case of small birds always preserve the 11ests as they are often more interesting and valuable than the eggs themselves. All the eggs of the same nest, and the nest, being numbered the same, by a reference to the little note-book the identification of any eggs (even if they get nixed) is very easy and the history of any specimen can be ascertained. If an egg has been set on very long this will be found a good process to clean ont the embryo. Make a little larger hole than usual in the side, pick out as much of the young bird as you safely can and then blow water into the egg with a blow-pipe; let it stand for some days in a dark drawer or box. Keep repeating this process about every third day, gradually blowing more water into the shell and picking a little ont till the whole of the embryo has decayed and is removed. This is a safe and sure way for a rare and valuable egg. I often put large eggs where the cabinet-bug - Dernetes - can get into them and clean out any foreign matter adinering to the shell.

Among the subjects in which Mr. Boardman was interested were those of albinism and melanisn. These singular freaks in nature, the perfectly white bird with pink eyes, the parentage of which was of a different fixed type; with the opposite of albinism, melanism, the abnormal development of black or dark pigment in the pelage of an animal or the plumage of a bird, interested Mr. Boardnian greatly. He had the largest collection of albinos among his birds of any private collector in the United States. In his museum were the following the list having been copied from the catalogute of birds 
which went with his collection to the New Brunswick government :

Moeking Hirt,

Bobolink,

Snow Bircls (2),

Barn Swallow,

Red-wing Blackbird,

Purple Finch,

Song Sparrow,

Cow Bunting,

Savannah Sparrow,

Chipping Sparrow,

Little Blick-head Duck,
Common Crow,

línfled Grouse (2),

Butter Ball,

Robins (1 pair),

Baltimore Oriole,

Bank Swallow,

Pail,

Wilson's Snipe (2),

Woodeock,

Cedar Bird,

Red-tail IIawk.

In the Bulletin of the Nuttall Ornithological Club, Vol. III., page 47, January, 1878, appears the following note on the melanism of the Robin - Turdus migratorius - by Elliott Cones, which is very interesting:

A case of melanism of 'l'urius migratorins, much less frequent (except in Falconidae) than leucism, comes to my knowledge through the atcention of Mr. G. A. Boardman, who desires me to make a note of it for the Bulletin. The young Robin, "as black as a Grackle," is still living in $\mathrm{Mr}_{\mathrm{r}}$. Boardman's possession. About two months ago this ormithologist heard of a nest of black Robins being taken at St. John, and wrote to the owner or collector about it. The person, however, lost his life in the great fire which occurred there, and Mr. Boardman, not liking to trouble the family by writing under such circumstances, went to St. John and inquired about the black Robins. 'The story proved true, and one of the birds was purchased. "When 1 first got the bird, "writes Hr. Boardman." he was in pretty good plumage, but his feather's are now half out, and I am hoping that he will not disappoint me by coming ont red. Most of the feathers on his head and neck are new, I think, and jet black. His tail is now gone, but that was pure black too. I see no signs of the normal plumage." Mr. Boardman writes me later, under date of September 23, that he has been much interested in watching the moult of the black 


\section{THE NATURALIST OF THE ST. CROIX}

Robin, and says: "He acts as if he were going to be an albino. His new tail is about half grown out, and is nearly white, with a black stripe down each feather. His breast, head, neck and back are jet black, but very much out of feather. He would now make a funny specimen - part albinic, part melanistic." The parents of these young were not peculiar in color. Since the above paragraph was penned, the bird has been liilled, stuffed and sent to the Smithsonian where I have seen it. It is black, with white wings and tail. - December 15, 1877.

Previous to writing to Prof. Coues about this black robin he had written to Prof. Baird, as appears from a letter to Mr. Boardman, dated September 26, 1877, in which he says: "I would not interfere with the movements of the Black Robi11. Let him turn himself into a white one if he chooses. Do not kill him until he has completed his vagaries. You must write out the whole subject in detail and publish it. It will be of very great interest." On December 5, 1877, Prof. Baird writes: "Much obliged to you for sending the robin and I shall probably be able to acknowledge its receipt before closing this letter. In your article about the bird give first its listory; how it came into your possession; what its coloration was when you had it; when it moulted; what change took place then; how long this was in operation; whether the single feathers changed their color from white to colored, or the reverse; whether the change was in new feathers coming out," etc. Writing on December 12 , of the same year, he says: "The Black Robin was received and is a great curiosity, greater than I anticipated from your letter." What an interesting thing is a bird, especially if it be a black robin or a white crow.

While Mr. Boardman's greatest love of natural history objects was for that of birds, he was well informed upon 
all other branches of natural history and out-door life, was an experienced woodsman and a famous and enthusiastic angler. The adjacent lakes, streams and salt water estuaries of the St. Croix system in the days when Mr. Boardman was in his prime, constantly furnished him with the best fish that ever graced a hook - not only the pelagic roamers of the ocean, but the landlocked salnon, togue, trout and salmon of the waters inland, the lakes and streams which he knew so well. Prof. P. W. Glover, for many years in the United States Agricultural Department at Washington, was a comrade of his in the days when landlocked salmon bore the name of Salmo gloveri ; and the two were the first to determine the species and class it accordingly. In an entertaining letter dated at Calais, May 1, 1887, to Mr. Charles Hallock, Mr. Boardman enumerates some of his earlier angling friends, from which an extract is made :

There were Rev. Dr. George W. Bethune; Rev. James Smith, a Baptist minister of Philadelphia; Geo. P. Trott of Philadelphia; George Dyer, a lawyer of Washington, D. C.; G. P. Whitney of Boston, a noted fisherman, with Ben French, Stephen Pineo, Joln Pollice and Frank Waite as river men and guides. Senator George F. Edmunds was up once or twice with one of my sons, and had great sport. Henry Ward Beecher and his father were up, and also Walter M. Brackett, the fish painter of Boston; my brother, Wm. H. Boardman and Geo. M. Porter of St. Stephen. Mr. Babcock of Boston, died from snake bite in Florida at Pine Island two years ago. Frank Kennedy, also a fisherman, was with bim. Stimpson H. Dennison, Boston; Geo. H. Richards, Boston; his father, Francis Richards, and Uncle Henry Richards used to come up years ago; Judge Ritehie of New Brunswick; Dr. Leith Adams, Prof. Bailey of Fredericton, N. B., and many others whom I do not now recall to mind. It is over fifty years ago since 1 began to go to the lakes, and I can see great changes. Fish then were 
very abundant, but have now beeu killed by tanneries, piekerel, etc. Our St. Croix river used to be a great lseeding place for water birds, but since pickerel were put in about thirty years ago they have most all left. Pickerel destroy the chicks, so that very few dncks or grebe now breed with us. Year before last there was very good salmon fishing with fly just ahove the toll bridge between (alais and Milltown.- Some were taken last year, but not so many as in former years.

One of Mr. Boardman's sons furnishes the following interesting incidents showing the exactness of his information regarding bird life and the estimation in which he was held by learned men in Great Britain: "Father did not begin seriously his ornithological collection until he had been in business for nearly a quarter of a century. He therefore brought to it the trained instinct and exact knowledge of a thorough business man. He spent nearly twenty winters in the state of Florida, and while there, from 1868 to 1873 , he made a collection of the birds of that state for the Smithsonian Institution. Prof. Spencer F. Baird, who succeeded Prof. Henry as Superintendent of the Smithsonian Institution and afterwards as Fish Commissioner of the United States, stated that father was the only one whose returns to the Institution needed no correction. Henry Osborne, who for a number of years was the president and general superintendent of the railroad running from St. Andrews to DeBeck Junction was something of a 11aturalist and a great friend of my father. He now lives in London, England. About four years ago I lunched with him in London at the Carlton Club. He kindly took me about to the London Society of Natural History, the British Museum, the Zoological Gardens of London, and introduced me to the managers thereof, and I confess I was not a little 
surprised at the acquaintance they had with father's writings as an ornithologist and a man of exact knowledge on scientific matters. Mr. Osborne stated to me that he considered father the best friend he ever had; that his advice and counsel, of which he availed himself continually while in this conntry, saved him at least once from bankruptcy. I also visited Henry E. Dresser at Topclyffe Grange, Farnborough, Beckenhan, Kent, England, who, together with the oldest son of Baron Rothschild, brought out the most elaborate and learned work on the Birds of Europe ever published, with life size portraits of the birds in colors. Mr. Dresser visited father at Calais in 1860 or 1861 , and speaks not only all the European languages, Russian included, but also Chinese and was for many years in correspondence with father. Mr. Dresser informed me that in the comparison between the American and European birds of kindred species, in which there is quite a difference in size and coloring in many instances, he relied outside of his own experience more fully upon father's descriptions than that of any other collector."

The formation of Mr. Boardman's large private collection in ornithology represents but a part of his work of this kind during the years in which he was engaged in active field study and collecting. He carried on an extended correspondence with naturalists in all parts of this country, in New Brunswick, in Canada and in England. With many of his correspondents he also engaged in a regular and business-like system of exchanging specimens, his correspondence showing how extensive these exchanges were. He made many gifts to institutions and museums, including the Boston Society of 
Natural History, Boston, Mass.; Museum of Comparative Zoology, Harvard University, Cambridge, Mass.; Essex Institute, Salen1, Mass. ; Portland Society of Natural History, Portland, Maine; Natural History Society of New Brunswick, St. John, N. B.; Zoological Society of London, London, Eng., and the Smithsonian Institution and Department of Agriculture, Washington, D. C. He also exchanged specimens with the commercial naturalists in New York and Philadelphia.

On nearly every one of his vessels that carried lumber to foreign ports a box of specimens was sent by Mr. Boardman to some correspondent and often separate smaller boxes and parcels to other individuals were included. Naturalists were constantly writing to him for specimeus and his response to their requests were always liberal and prompt. Mr. Boardman's largest contribution was to the Smithsonian Institution, Washington, D. C., regarding which the Secretary, Prof. S. P. Langley, says: "The records here show that Mr. Boardman contributed to the collections forty-eight accessions, consisting largely of birds and bird skins and comprising in all nearly two hundred specimens. The most noteworthy of Mr. Boardman's gifts to the Institution were several specimens of the now extinct Labrador Duck (Camptolaimus labradorius), which is very rare, a single skin being worth at the present time about $\$ 1,000$."

In reference to this very valuable contribution to the Smithsonian it is related that when in New York, on one of his visits to the South, he went to the museum in Central Park, which had some duplicates of these ducks and the director ordered an assistant to pack the ducks and send themto Mr. Boardman's address in Washington. Upon his return from the south, in the spring, he 



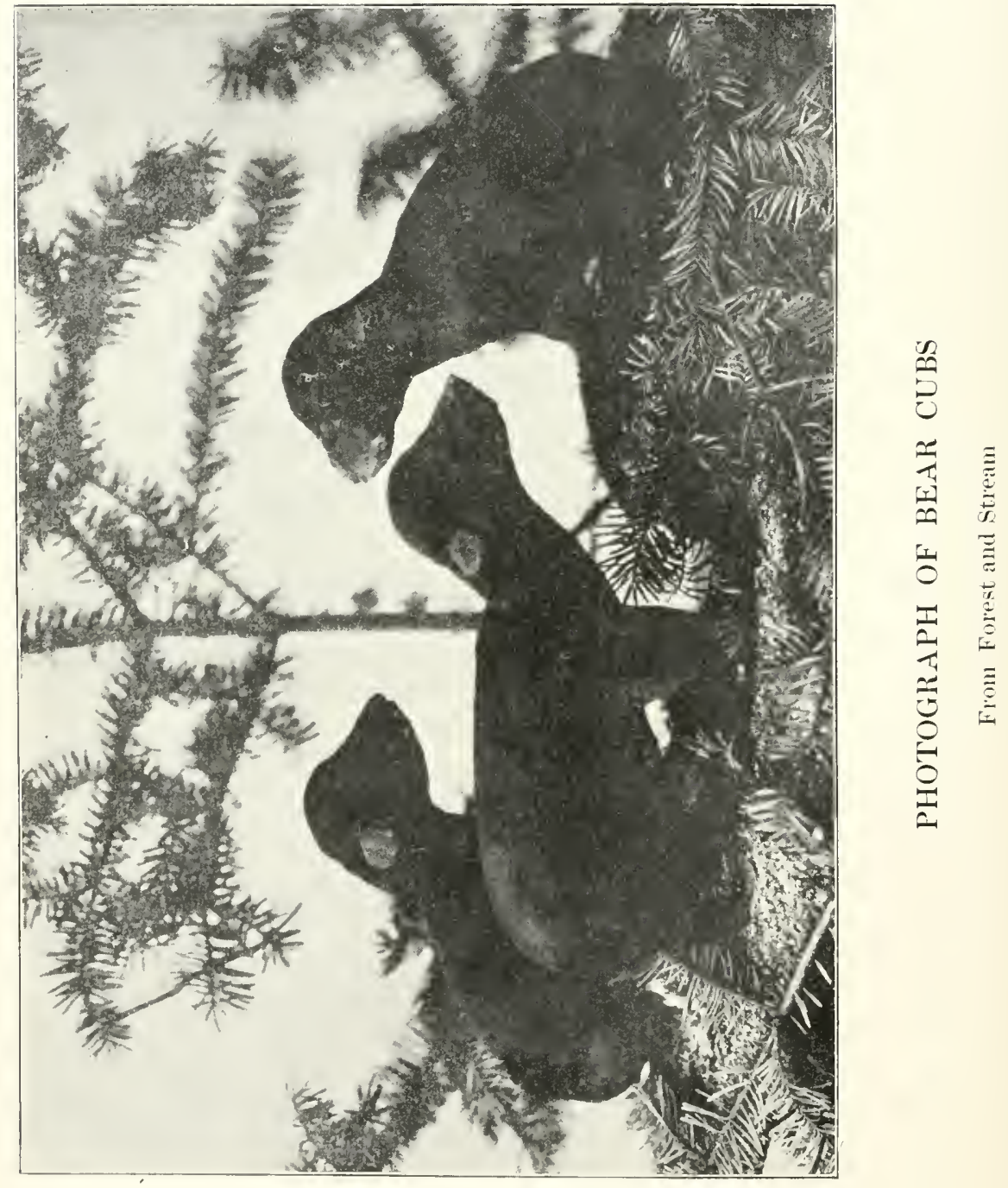


was surprised to learn from Prof. Baird that they had not come. When on reaching New York lie went to the museum and told the director that he had not received the ducks. The director sent for his assistant and asked why he did not send the ducks to Mr. Boardman as instructed last fall. He replied that he did not think that the director knew how valuable they were, to which he replied that there were " 110 duplicates in the museum too valuable for Mr. Boardman."

Among the animals in which Mr. Boardman was much interested were our native bears. Writing in Forest and Stream of March 4, 1899, about the ways of bears, he says: "I have found great trouble in getting specimens of very young bears. The hunters, always in a hurry to get their bear bounties, take them to the treasurer for the money and he cuts off the nose from the skin of the old one and the whole head of the little ones. In my many winters in the south and in California, where bears do not den, I have never been able from the hunters to find one nor ever had seen one until it was old enough to follow the mother." Great was Mr. Boardman's delight, therefore, when, in February, 1900, one of his woodsmen found a female bear in a den with three cubs - "queer little things," he says they were in an article published in Forest and Stream of March 17 of that year. " They weighed about twelve ounces each; length from end of nose to end of hind toe, twelve inches - not much larger than a full grown red squirrel. They lived about a week after the old one was killed. From the umbilicus being entirely healed I should judge them about two weeks old." A photograph of these young cubs was published in Forest and Stream and is here reproduced. 
Mr. Boardman sent a copy of this photograph to his grand-daughter, Marjorie Boardman at Minneapolis, Minn., writing her a pretty letter February 22, 1900, in which lie said: "I wrote your father about my woodsman who killed an old mother bear that had three little baby bears that did not liave their eyes open. They only lived about a week after the mother was killed. It was too bad to kill the old mother bear, but, I suppose she had no business to have been a bear.' No natural history specimens which Mr. Boardman ever had pleased him nore than those cubs, as he considered them very rare.

Mr. Boardman was a naturalist of the old school and employed the methods of the old field naturalists in his studies and his collecting _ "first shoot your bird." But there was nothing wanton in his work. He was careful and humane. Even as early as 1869 he deplored the wholesale slaughter of the birds in Filorida, killed by the hundreds for their plumes and at that time was anxious that laws should be enacted and enforced for their protection before they should become exterminated. Later our own laws for bird protection and the requirements of a license to take birds for scientific purposes met with his earnest and hearty support. Practical woodsman tlat he was, as well as naturalist, Mr. Boardnian knew the whole art of woodcraft. He was used to camps and acquainted with canping outfits. He knew all the birds of the woods by their song, his favorite warbler being the Hermit Thrush. He knew all about guns and dogs. In one of his autobiographical sketches Mr. Boardinan recalls that in his early life the brothers, Henry and Francis Ricliards, who came from England as agents of the rich Binghams 
who owned large tracts of timber land on the St. Croix, were the first men he had ever seen to shoot snipe over trained dogs. He had made a study of guns and many letters on the subject passed between himself and Prof. Baird, the latter recommending the Maynard gun which Mr. Boardnan used to great satisfaction. He was known from Maine to Florida as the best wing shot of his day. Regarding dogs he had much correspondence with Mr. John Nesbit, Jr., of Cambridge, Mass., who was one of the most famous importers and breeders of setters of his time and Mr. Boardman used to say the reason his own dogs knew so much was because they came from the town where Harvard University was located.

Throughout Mr. Boardman's long correspondence with naturalists, extending over many years and embracing hundreds of letters, only a single instance occurs in which he expresses any desire for personal recognition. This occurs in a letter to Prof. Robert Ridgway written from Calais, December 8, 1884, in which he presents that naturalist with a skiu of Falco columbarius, from Florida. From that letter the following extract is made:

I do not know as I should have written again so soon only you said you would return the skin; but if it is so unique a specimen and among your great numbers have none like it, the right place for it is the United States Museum, as you might want it for purposes of comparison. I did not suppose you could make a new race from one specimen and do not remember as I said anything about race. But I described this in such a way that if it should prove different when you get other skins with which to compare it before others may do so, as to be ahead and call it Boardman's P'igeon Hawk. I have been sending lots of queer specimens to Washington ever since Kennicott's time and if I have found one which you can call for me I shall be well paid. 


\section{CHAPTER VIII}

\section{PERSONAL CHARACTERISTICS}

NE; of the most prominent characteristics of $\mathrm{Mr}$. Boardman's individuality was his intense devotion to that subject in which he was engaged. Whether it were business, science or recreation, he gave himself completely to whatsoever demands they made upon him for the time being. The conscientious devotion which he rendered to his employers' interests when a young man characterized him throughout his entire business career. An early riser all his life, he made a long day in the store, at the mill, in the business office. He expected his employes to be as faithful to his interests as he had been to the interests of his employers when a young man ; and many were the lessons of industry, econoiny and thrift which he gave to the men working for him in different capacities. As his business activities increased and their duties became more exacting he simply doubled his diligence and discharged most joyfully the added responsibilities.

His habits of business were most exact and methodical and he performed every duty the moment it was required. He never put off till tomorrow what could be done 
today. Grasping a business proposition or meeting a business contingency he surveyed it rapidly, judging and acting promptly and almost invariably his decision was right. He rarely made mistakes in judgment or errors in acting. It is but one illustration of this to say that only ten days before lis deatl he had balanced his books and brouglit forward an inventory of his estate up to January 1,1901 - everything being clearly stated and so complete that no mistake could possibly arise. Had this not been the case at each recurring year previously, it might almost have seemed as though he was expecting death.

In 1853, Mr. Boardman commenced a private diary, keeping the same in the small pocket form so well known, the little books being uniformly two and one-half by four inches in size and being printed and ruled to from six to ten lines under each day's date. The first entry was made Monday, January 14 and the record was continued for a period of forty-eight years. It is indeed remarkable that in this long time but two breaks occur in the daily record. The first was for a single day, March 1, 1884, when he was in Florida; the other from March 8 to March 23, inclusive, following the death of his wife and during his own severe illness. The records are necessarily brief, being made in Mr. Boardman's neat and uniform handwriting and generally with a pencil. They embrace items of personal expenses, state of the weather, where he was on each day, letters written, birds seen and shot, his occupations for the day, engagements, where he attended cliurch and who preached, with other similar memoranda. More than anything else this diary attests 


\section{THE NATURALIST OF THE ST. CROIX}

his methodical habits while its practice no doubt contributed to such habits, to his promptness and to his love of order.

Mr. Boardman was a man of domestic tastes and social temperament. The centre of his life was his home and he ever believed in its abiding influence for good. He always remained young and among his friends was at seventy what he was at forty-simple, alert, frank, bright, full of wit and story, quick at repartee, or serious in conversation if the occasion demanded it. His force and purity of character, his genial disposition and his winning smile always created an atmosphere in whatsoever company he entered. His presence never suppressed fun or light talk, while the gayest welcomed his coming and to the young he was a companion, while his tone was always pure, elevated and refined. At the same time he was sensitive to the feelings of others and to the conditions about him. To his wife he always turned with perfect confidence for sympathy and support. Speaking of his mother and of his recollections of home one of Mr. Boardman's sons writes :

My mother - the inseparable companion of my father for more than fifty years - was one of those sterling New England women of advanced ideas for her time, a model housewife, interested with father in the advancement of the educational facilities in the village, and perhaps no other person was more instrumental in the founding and maintenance of the beautiful cemetery at St. Stephen, in which lovely spot both she and father have a sepulchre. She was very fond of flowers and had for many years one of the most beautiful rose gardens in that part of the conntry. Unlike father she had noue of the Celt in her composition, but always regarded life as a serious proposition. She lived at a time when large families were the rule instead of the exception. 'Ihere were eleven of us children, ten boys and one girl, six of whom 


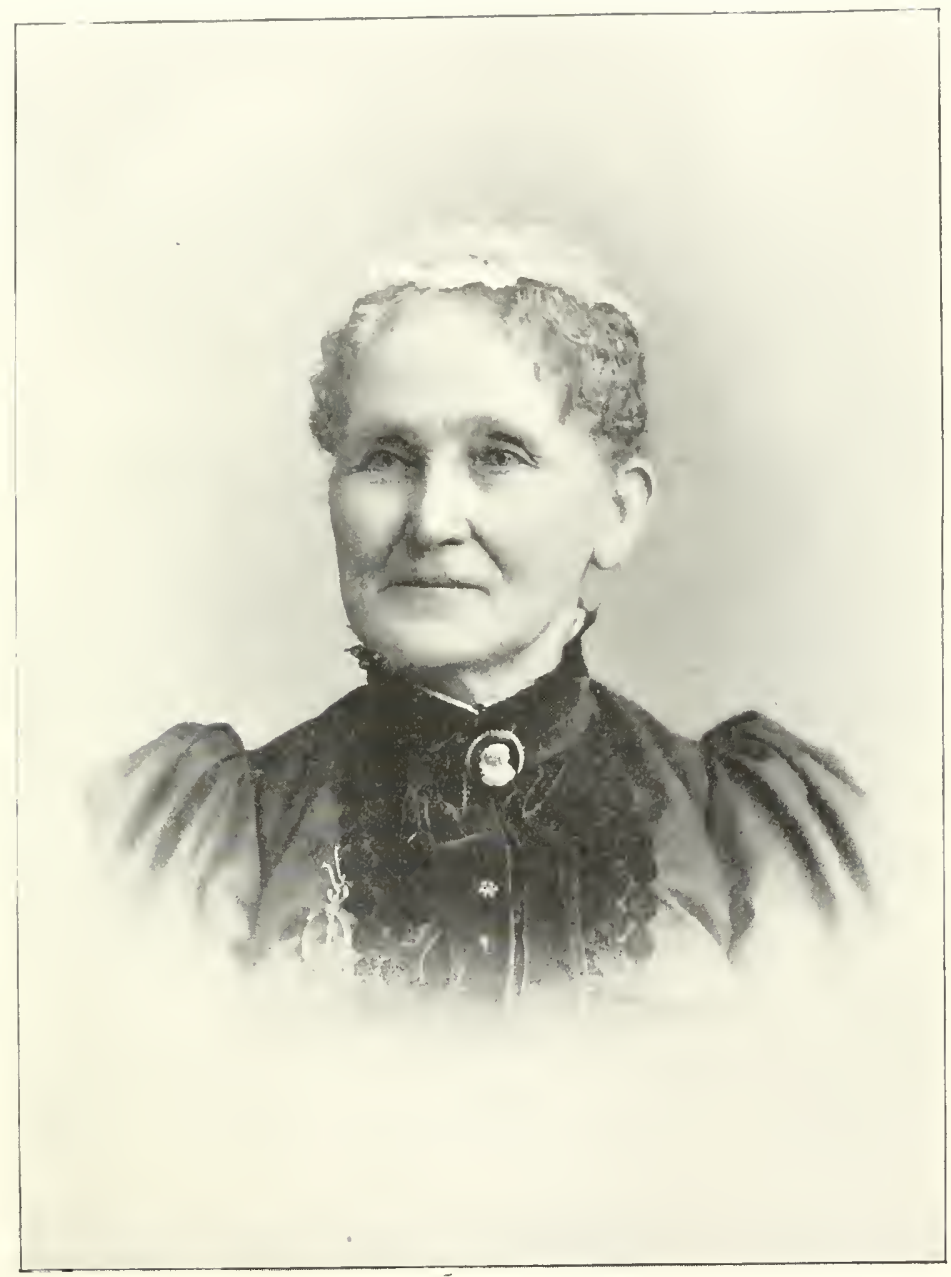

MRS. GEORGE A. BOARDMAN 

died in infancy. Our next door neighbor, Mr. Ed. Smith, had twelve children and on the other side the family of Mr. James Murchie, fourteen children, all of the latter save one, I believe, living to-day, and no finer family was ever raised in any community. Until the time of Mr. Murchie's death he was one of father's warmest and most intimate friends. Speaking of large families, $I$ attended my grandmother Boardman's golden wedding about my sophomore year in college, at which if my recollection serves me, there were seventy-two members of the family present, children, grand children and great grand children, none of whom had ever been accused of any wrong doing. And as I remember business men on the St. Croix liver, "captains of industry" as they are now termed, I believe there were more men living on the St. Croix at that time who were fitted to be President of the United States and more women who were endowed with gifts entitling them to reign, than in any community in which I have since lived.

Mr. Boardman was one of the few men who possessed the happy faculty of always remembering every one whom he ever met and being able to call them by name. When travelling he was always on the lookout for old acquaintances and enjoyed shaking hands and having a few words with them, generally ending with a hearty laugh. It made no difference whether it was a millionaire or one of his former workmen, a negro or a Chinaman - he treated them all as gentlemen and they all seemed equally pleased to see him.

$\mathrm{H}$ is excellent business judgment and always correct decision regarding investments were prominent traits in Mr. Boardman's character. This was shown all through his life but especially at the time the business revival came to Milltown, N. B., when the present cotton mill company located in that place. Beside his own home he owned four other pieces of property and a saw mill, including the water power and one-fourth interest in 
the water power where the cotton mill is located. He gave his interest in that to the cotton mill company to induce them to locate there; then sold them the land surrounding their mill, his homestead and the saw mill (as they wanted the power to pump water), a tract of land for homes for the employes and the balance he sold to other parties. It was the only time in the history of the town when there was any demand for property and he was the only one that showed the good judgment to sell. Another instance of his good business judgment was shown in his never making investments in Florida, although he had spent many winters there when northern men were investing largely in business enterprises that promised large returns; and when one of his sons also resided there, was himself largely interested in railroads, orange groves and hotels. None of them, however, could ever induce Mr. Boardman to invest in their enterprises to the extent of even one cent.

His love of home was a very strong trait of his character. His affection for the place in which he lived, had passed his active years and had made his money, was of a kind with his love of the domestic fireside and of his own family.

'To all the interests of the city where he lived he was devoted - the church, the schools, the streets, the town improvements. Connected with many large corporations, with banks, steamboats, railroads, shipping and mills, he realized their worth to the community and was always active and constant in the public duties they imposed. But when these had been attended to he entered into the social and home pleasures with all the vigor of youth. After having spent two or three winters with his 
children at the west, when it was not known but he might make that his future home, he returned to Calais with all the gladness of a boy returning after long absence to his childhood's home.

When asked by his sister if he was not to live in Minnesota thereafter, he replied: "Emily, I'd rather live in Calais and go up to the cemetery and read the names of my dead friends on their gravestones than to live in Minnesota for all there is out there." Not long before his decease a consensus of the leading citizens of Calais and St. Stephen had been obtained as to whom they regarded the most successful man who had ever done business on the St. Croix and the unanimous opinion was that it was George A. Boardman. He had been happy in his domestic relations; had been successful in business; had retired with a competency at a comparatively early period; had devoted his life, most rationally, to the pursuit of science; had won the friendship and confidence of the leading naturalists of the country and had secured the love and respect of his fellow citizens to the extent that he was easily the first citizen of the two cities in which he had spent his entire life. Measured by the standard not alone of dollars or political prominence, but of personal enjoyment, the fame that comes of worthy service and the happiness following a wellspent life, Mr. Boardman had lived the simple, successful life and had won the palm of deserved honor at the hands of his peers.

Because of his Massachusetts ancestry he possessed a large share of the Puritan conscience. If it ruled him to strict life and the performance of rigid duty it was, happily, a duty to which he willingly yielded, day by 


\section{THE NATURALIST OF THE ST. CROIX}

day, throughout his long life. He was always a constant, prompt and loving attendant at the Congregational church in Milltown and in Calais. When absent from home he always attended church and no entries in his diary are more regular than those which record his attendance at church in Philadelphia, Boston, New York and Washington where he always went to hear the most eminent preachers of the time. At home, when entertaining friends, he invariably went to church on Sunday, even if his guests did not; and when Prof. Baird and his family were his guests he records going to meeting while Prof. Baird "kept house." Returning from the south in 1865, he reached Portland on Fast Day, April 20, where he remained for the day and attended the union service at one of the churches. But he was liberal and tolerant. An anecdote is related by one of his sons :"While we lived in Milltown, in a house near the Catholic church, I noticed twice every year the priest came to the house to see father. In those days the Protestant churches imparted the impression that being a Roman Catholic was next to being entirely lost, so I inquired of him what the priest came for. After deliberating a few minutes he said, 'Albert, you know that within a year or two the Catholic parish here has constructed a new church, school house and residence for the priest. I sold them the lumber for this operation and, being a little short of money, they came to me for a loan. The priest comes twice a year to pay the interest and always comes promptly on the day it is due.' "

An extract from a letter to Prof. Baird written at Boston, May 23, 1869, shows the regard which he had for the observance of the Sabbath: "Saw Doctor Brewer 
yesterday. Think I will go down and make him a call this afternoon. It being Sunday he might be at work with his eggs, stamps, etc., and I can keep his mind away from such things Sunday."

While compelled to go out to service at the early age of thirteen years and being deprived of the advantages of an education in early life, he was determined that his sons should have a college education. Three were graduated from Bowdoin in the years 1866, 1869 and 1873, respectively, and the fourth, who preferred to go west, attended the University of Minnesota. "I do not think, however," says one of those who went to Bowdoin, "that all of his sons combined, with the advantages he gave them, ever acquired an education comparable with that which he himself assimilated through his most extensive reading and association with scientific and literary men." He continues: "Personally, about the only things of any service in life which I ever learned came from my association with my father during our only too brief communion. The love of nature, which came to all of us boys from our father and mother, has been my chief treasure. From them we learned to love the secrets of the woods, the notes of the birds, the hiding places of the arbutus, the murmur of the pines, the pool beneath the alder shade where the trout lie hidden and to love our dumb companions. Their love of the beautiful was in contrast with many homes I can remember."

Mr. Boardman's personal acquaintance with the leading naturalists of the country was very extensive. In Boston, New York, Washington, Philadelphia and throughout the south he knew all the ornithologists of note, although he did not correspond with them as often 


\section{THE NATURALIST OF THE ST. CROIX}

as he did with his more intimate friends. His brother Gorham, who resides in Brooklyn, writing in 1902, says: "I was, several summers ago, when at Nantucket, introduced to a gentleman who said, "Mr. Boardman, what, Mr. George A. Boardman of Calais, the ornithologist?' I replied 'no, but I am his brother.' 'Well,' he said, 'he is known by every lover of birds from Maine to Florida.' "' In whatever place he was, from Maine to Florida or from Washington to the west and to California, there were those whom he knew. And he prized their friendship. It was his first duty at every place where he stopped on his many journeys from one state to another "to go all around and see the folks" or call upon his scientific friends. He loved to do this and it was a duty as well as a pleasure that was never neglected. The same was true when Mr. Boardman returned to his home in Calais from winters spent in Florida or at the west.

His good nature never forsook him. He was always cheerful and sunny. The apt story, the winning smile or the hearty laugh were evidences of his happy disposition. He was thoroughly unselfish. Nothing is more common in letters to his scientific friends, when describing anything new, rare or curious that he had obtained, than for him to say: "This specimen I will send to the National Museum that it may be available for comparison; it is too important to be kept in a private collection." When in Washington he was most attentive and helpful to persons in Maine who were interested in visiting the departments or the museums. Many have been his acquaintances who tell of the pleasure they had in being conducted through the exclusive formalities of Washington life by 
Mr. Boardman, who, from his familiarity with the departments and acquaintance with their chiefs, had the advantage of the inside knowledge of thinsg which he shared with his friends.

Prof. Leslie A. Lee of Bowdoin College, Brunswick, who was chief of the Albatross scientific corps in its dredging work under the United States Fish Commission in 1885 and 1886, tells how, in the evenings after work was over as they were seated upon the veranda at the headquarters building at Woods Holl, Prof. Baird for hour after hour, would talk about Mr. Boardman, of his rare attainments, his accurate knowledge, his keen observation and tell story after story of their experiences together in the Maine woods or in their studies at the Smithsonian at Washington.

Mr. Boardman was very fond of reading. In fact, as his daughter Mrs. Taylor says, he "read everything" excepting novels and was very fond of the poetry of Browning. He took regularly seventeen magazines, journals and newspapers and read them all. In a letter to Prof. Baird written at Milltow11, N. B., November 30, 1879, he says: "I am hard up for reading matter. Have not seen a Smithsonian report for a long time; should be glad of most anything." Again, writing to him from Minneapolis, March 6, 1883, he says: "Cannot you send me something to read. Have not seen a Smithsonian report for a couple of years, nor any of your bulletins. There are very few naturalist folks here, all are on a rush for business. I have found Chicago the same, no collectors of anything." $\mathrm{He}$ had a splendid memory, remembering everything he read and the names of all persons whom he ever met. He was very regular 
in his habits, generally retiring at nine o'clock in the evening. He always looked on the bright side of things and remained a boy all his life. This cheerfulness and good nature, the optimistic view he always took of human affairs, was founded upon his belief in the Divine goodness and in the benevolent order of all things as directed by the Great Creator. A single passage from a letter written to Prof. Baird at his brother's office in New York, when Mr. Boardman was on his way south, is of deep interest in this connection. It is dated January $12,1869$. "I was much surprised," he writes, "to hear of the sudden death of Mr. Cassin. Mr. Lawrence told me this morning. I hardly know what Philadelphia and all the naturalist people are to do without him. How many of our naturalist friends are being taken away. But it is just as natural to die, as to be born and all we can do is to be ready when we are called." No one who knew his life could ever have had a doubt but he was ready, always, for the final summons.

How did this plain, unschooled man become the friend of the great scientists of the country? What elements of character did he possess which made him their close and trusted companion and co-laborer in the paths of science? It was because he possessed a union of the characteristics which have just been outlined. He was a true lover and devout worshiper of nature. He was endowed with an extraordinary natural gift for the acquisition of scientific knowledge; few men living and few men who ever lived had the gift of knowing birds and bird ways in so generous a measure as did Mr. Boardman. His moral qualities were of the highest order and his frank, genial personality won friends to 
him which his noble character, friendliness and unselfishness made sure and constant. His friends were friends for life. He never lost enthusiasm for his studies in ornithology and was always making some real and true additions to the sum of human knowledge in this interesting science. His words were those of truth and his life was simple, noble, honest.

Among the articles which Mr. Boardman contributed to the Calais Times during the last few years of his life was a biographical sketch of his friend, the late James Murchie of St. Stephen. The closing paragraph of that fine article applies with great aptness to Mr. Boardman's own life: "There was manifested in him none of the decrepitude or petulance of old age. When last I saw him, his face was sunshiny, for his 86 years had always been maturing goodness. The length of his life is neither magical nor mysterious, when we consider certain habits and dispositions which he possessed. $\mathrm{He}$ lived simply and loved simplicity; he was unostentatious, industrious, frugal and democratic. Temperate in all things, he was a later day Puritan, an improvement on the old Puritan in that it adds cheer to a loyal devotion to the right. His great age was beautiful simply because his youth had been so; his October was the natural result of his May. His latter days had a magnificent maturity because in his younger days he had always sought that which was good. He was like one of those glorious maples that we see in October, that nature crowns as the resplendent monarch of the surrounding forest." 


\section{CHAPTER IX}

\section{APPRECIATIONS AND HONORS}

A 'T Mr. Boardman's death the local, general and and eulogy. A selection from those published with some extracts from private letters addressed to members of his family are given. An extract is also made from an article contributed to Forest and Stream of August 5, 1899, by his friend, Mr. Charles Hallock. In order to avoid unnecessary duplication biographical and business details have generally been omitted from the following appreciations :

Charles Hallock, in Forest and Stream, August 5, 1899

'The honored subject of this sketch seems to be one of those elect whose lives have been graciously prolonged because of their usefulness to men. Recognized for three-quarters of a century as a keen, discriminating naturalist, and possessing the most complete private museum of natural history extant, he is now in his eighty-6econd year, as painstaking as ever in his investigations, devoting himself with energy almost unimpaired by time to his favorite pursuit and study. Statedly, every week he contributes to the Calais Times an article on such natural history subjects as engage the interest of household readers and inform them of the peculiar places which our familiar creatures of the fields and 
swamps and woods occupy in the animal kingdom. In this manner he does much to remove prejudices against insects, birds and reptiles deemed noxious, and this helps to preserve the biological balance among associated fauna.

Now it happens that students and scientists who have become eminent in their profession are usually so segregated and intent on their transcendental pursuits that they often fail to become conspicuous among the world's honor men; and hundreds of such are enrolled on the unpublished book of the immortals whom the general public has never heard of, simply because they occupy a superlatively higher plane. These have no time to exploit their achievements. Such a man, I may be permitted to say, is George A. Boardman of Calais, Maine, an ornithologist of highest repute among scientists, a contemporary and whilom associate and coworker with Audubon, Agassiz, Downs, Todd, Baird and Bethune, those studious observers of natural objects whose renown lingers after their departure like the afterglow of a midsummer sunset. Scores of his rarest specimens have gone into the Government collections at Washington, not withont a transient pang, yet with heroic recognition begotten of a keen sense of Uncle Sam's priority and inherent right of possession. For example, he had in his museum at Calais (which is installed in a spacious two-story building devoted exclusively to the purpose) an incomparable lot of Indian stone implements of most every kind, including some fine spear heads found at the Grand Lake Stream while digging for the first dam in 1860, not far from Dr. Bethune's old camp. Prof. Baild, he remarks, ingenuously enough, "thought the Government Museum had the best right to them and took them away."

"When Prof. Baird used to visit me," he writes, "we used to go among the elderly people aud pick up lots of trumpery such as spinning wheels, flax wheels, old canoes and Indian things. I had a queer old wooden anchor which was dragged up in the lake, such as Indians used to hold their canoes while fishing. Baird thought this a good find. There was a shell heap about twelve miles below here that we used frequently to visit and dig over. He was a very happy man when on the hunt for relies. Even after he was taken sick he used to write me that he wanted to come up and finish that shell heap." 


\section{THE NA'TURALIST OF THE S'T. CROIX}

The chief feature of Mr. Boardman's zoological collection is a complete presentation of the local fauna of Maine, including 278 species or varieties of birds found in the eastern section. 'The museum in its entirety comprises some 2,500 specimens, mounted and in skins, with the young and eggs of the most of them; also a good collection of horns - thirty-five different kinds. Among his rarel miscellaneous specimens are the skins of a black wolf and of a bay lyux (Lynx rufus), both obtained in Florida, where he passed no less than twenty winters.

Mr. Boardman has been prominent all his life in important business interests, and now is in banks, in steamboats, vessels, lumber and mills. In 1870 he retired with a competency, but his time is quite fully occmpied in a variety of ways, the public for the most part being benefieiary.

\section{J. A. Allen, in The Auk for April, 1901, Vol. XVIII.,} Pages 219-220

Mr. George A. Boardman, an Associate Member of the American Ornithologists' Union, died at his home at Calais, Maine, Jan. 11,1901 , at the age of 83 years. He was born in Newburyport, Mass., Feb. 5, 1818, and went with his parents to Calais in 1828. Uis ancestors came from Yorkshire, England, and settled in Newbury, Mass., in 1637. Mr. Boardman, for over thirty years was engaged in the lumber business on the St. Croix river, retiring from active business in 1871. He was well known as an enthusiastic naturalist and sportsman and was a warm friend of the late Dr. 'T. M. Brewer and Professor Baird and of many later and less prominent naturalists. It was his habit for many years to spend his winters in Florida, stopping at Washington, New York, and other points on the journey to and from Maine to his winter home, to renew acquaintance with his many naturalist and other friends.

The present writer first made his acquaintance at Jacksonville, Florida, in December, 1868, and later the same winter passed a few days with him at Enterprise on Lake George. He had already become familiar with the bird life of Florida, where for many years it was his labit to collect specimens and take field notes, giving liberally of his specimens to Professor Baird of the 
Smithsonian Institute, and sharing his field notes with other workers. As early as 1862 lie published a Catalowue of the Birds Found in the Vicinity of Calais, Mane and about the lslands at the Month of the Bay of Funly (Proc. Boston Soc. Nat. Ilist., IX., H). 122-132), an annotated hist of 231 speeies. IIis collection of Mane birds is notably complete, numbering, it is said, 278 species (cf. Forest and Stram, August 5, 1899) and comprising sone 2,500 specimens, mounted anu in skins, besides a large collection of eggs. He was a frerpuent contributor to Forest and Stream and other natural history journals, including the Anerican Natulalist aud the Bulletin of the Nuttall Ornithologieal Club, and up to the last Jays of his life is said to have contributed, "statedly, every week," to the Calais limes, "an article on such natural history subjeets as engage the interest of the household readers and inform them of the peculiar places which familiar creatures of the fields and swamps and woods occupy in the animal kingdoill."

Mr. Toardman was a man of genial and attractive personality, and after his retirement from business, some thirty years ago, devoted much of his leisure to travel and natural history pursuits, his interest in such matters having a wide scope.

\section{The Calais Times, January 17, 1901}

It is with profound grief that the 'Times records the decease of this eminent citizen. Mr. lBoardman passed peacefully into pleasant dreams, at his home on Lafayette street, last Friday moruing. In our sense of personal sorrow which the event briugs, all readers will share. His weekly artieles contributed to this paper during the past five year's, on scientific, ethical, educational and political subjects would fill a volume. IIis last article was published in the issue of December 20, on the subject of Wars of the Century. He was also a contributor to other papers and llugazines, especially the Forest and Stream, for many years and until two weels before his death, and the constant demand for his writings attested their merit and the interest they aroused.

It will require more than a single article to portray $\mathbf{M r}$. Boardman's life, work, and qualities, all of which were of a kind to induce respect, confidence and friendship. His life was in the 


\section{6 'THE NATURALIST OF THE ST. CROIX}

daylight, and he was esteemed of all acquaintances. $\Lambda$ t an outing of prominent citizens, three years ago, it was decided by a unanimous vote that George $A$. Boardman, of all men who had resided in the St. Croix valley, had best enjoyel the blessings and fruition of human life. Successful in business, fortunate in family relations, contented in his studies, broad and keen in intellect, varied in accomplishments, staiuless in character, observant of affairs, with ample wealth, he was passing his declining years with a happiness that befitted a naturalist, Christian and nobleman. He was the last of the aggregation of great business men of the last generation who won fortune from the lumbering industry here.

He conducted the largest lumber business on the St. Croix river until 1871, when he retired from active business to enjoy the fruit of his labor in travel and in pursuit of his favorite study. He had been a noted naturalist and an authority on ornithology for nearly fifty years. His private museum comprised the finest collection of monnted birds in New England, if not on the continent.

He liad studied the fanna of Maine as no other field naturalist has ever done, and passed twenty winters in Florida and other southern lands in pursuit of his favorite studies. He was a life member of the Natural History Societies of Boston, Mass., and London, England, a lifelong friend of Profs. Baird and Coues of the Smithsonian Institution at Washington, Dr. Brewer of Boston and Charles Hallock of New York. Among his other scientific and literary friends were Rev. Dr. Bethnne, the eminent theologiau, Senator Geo. F. Edmunds, Walter Brackett, the celebrated painter of fishes, Rev. James Smith of Philadelphia, Prof. Bailey of Fredericton, N. B., Dr. Leith Adams, Judge Ritchie of New Brunswick, Henry Ward Beecher and scores of other eminent personages.

\section{St. Croix Courier, January 17, 1901}

By the death of George A. Boardman the valley of the St. Croix has lost one of the most aged and best known of its residents. By reason of his extended life and the variety of interests which he touched, added to a genial and social disposition, he 
became known to an unusually large number of people. Ilis departure creates a vacancy in many circles.

Having acquired an ample competence in business Mr. Boartman exhibited a rare spirit of contentment with his acquisitions and in mirtife witharew from active business that he might devote himself to other interests.

He had hecome deeply interested in ornithology. 'I'he first impulse in this direction is believed to have been received when, on a visit to South America in charge of a cargo of lumber, he was struck with admiration by the birds of brilliant plumage there seen. He began to collect specimens and learn the art of mounting them. 'Thus was laid the foundation of the notable collection which he has left, embracing representatives of all the land and water birds fonmo in this section of the country, together with not a few from other localities. In the collection are to be found also the eggs of all the species and the nests of many. 'These specimens, by the completeness and the fine skill with which they have been prepared and mounted, form an ornithological cabinet which probably has no equal in New England, at least in private ownership.

'The pursuit of this branch of natural history brought Mr. Boardman into acjuaintance with men of science in different parts of the contry. 'The list of his distinguished friends would be a lengthy one, friends who were attracted to him not only by a common taste, but also by his kindly disposition and warmth in friendship. He was a member of the natural history societies of Boston and of London and was acenstomed to contribute papers of value to the publications of these boties.

\section{The Calais Advertiser, January 17, 1901}

In the deatl of George $\Lambda$. Boardman, who departed this life Eriday morning, Calais loses the last of the old line of lumber manufacturers, who developed that industry on the St. Croix and turned the wilderness into a eity of homes for a prosperous people. Having amassed a competency, Mr. Boardman reciled from active business life, although retaining a lively interest in several companies in which he was a shareholder, and at the time of his death was president of the Frontier Steamboat Company, 


\section{THE NATURALIST OF THE ST. CROIX}

having suceeded the late Tames Murchie. After his retirement Mr. Boardman gave the greater part of his time to the study of natural history, and especially to the fauna of Maine and New Brunswick, and was eonsidered an authority in everything pertaining to ornithology. IIe possessed considerable literary ability, and was a valued contribntor to several periodicals. Mr. Boardman's eheerful countenanee and genial manner will he inissed by old and young, rich and poor, for he had a kind word for all.

\section{The Maine Sportsman, February, 1901}

Sportsmen and naturalists everywhere, acquainted with Mr. George A. Boardman, of Calais, will keenly regret to learn of his death which took place on the morning of January 11. In spite of the fact that he was within two months of being eighty-three years old, his mind was clear and active and he kept in close toneh with the progress of natural history study in New England and particularly in Maine, in which he was greatly interested. Mr. Boardman had a most genial disposition and, although the writer met him but once, yet he carried away such pleasant memories and anticipations of future meetings, that he feels as if he, as well as the ornithologists of New England, had met with a personal loss in the passing over of this kind, helpful, earnest man.

\section{Minneapolis Journal, January 12, 1901}

George A. Boardman, one of the most learned naturalists in the United States, died yesterday morning at his old home in Calais, Me., at the advanced age of eighty-three years. He was the father of County Attorney Fred H. Boardman and Mr. W. B. Boardman of this eity, and Mr. A. J. Boardman, now of Philadelphia, but formerly a prominent Miuneapolitan. The deceased had been a successful business man and was interested in banks, lumbering and other industries, as well as iu shipping. He retired from the aetive affairs with a competence in 1870 to oceupy himself with his favorite studies and public matters. His natural history museum is conceded to be the finest and largest private collection in America. In the Zoologieal collection alone there are 2,500 specimens mounted and in skin, with the young and eggs 
of most of them. Not only was he a student and naturalist, but a keen sportsman as well aud a famous and enthusiastic angler.

\section{Boston Journal, January 13, 1901}

George A. Boardman, a prominent and wealthy citizen of Calais, Me., died at his home Friday morning, January 11, aged eighty-three years. He had been a noted naturalist and an authority on ornithology for nearly fifty years. Ilis private museum comprised the finest local collection of mounted birds in New England, if not on the continent. It is to be placed in one of the Government buildings at Fredericton, N. B. and to be known as the George A. Boardman Collection. He contributed many interesting articles to Forest and Stream and other magazines and papers, up to within two weeks of his death. 'The last issue of Outing speaks of him (with others) as one of the noted sportsmen of the past century.

\section{Forest and Stream, January 26, 1901}

'The death of Mr. George A. Boardman, recorded in another column, removes from the list of Forest and Stream's subscribers, contributors and readers one of the very oldest. Mr. Boardman was for a large part of his life an active business man, but like many of those who work lardest in the world's business, he made time to pursue what was his pleasure as energetically as he did his business. For more than fifty years he had been a naturalist, and had done work with and aided some of the most eminent of the naturalists of this country. Aulubon, Agassiz, Baird, Downs and others were among the men with whom Mr. Boardman was associated, to whom he freely gave of the interesting faets that he had colleeted and among whom to some extent he distributed the collections whieh he had made.

Notwithstanding this generosity, he was able to gather together a very large museum which, as might be supposed, represented with singular completeness the fauna of eastern Maine. Mr. Boardman was thus naturally one of the first authorities on the fauna of the extreme Northeastern United States, and it was to him that applieation was first made for information on that subject. 


\section{THE NATURALIS'T OF THE ST. CROIX}

Besides his fondness for nature, he was a keen sportsman, and above all, an enthusiastic salmon angler, and very many of the oller aud better known anglers of the Eastern United States used to visit him and fish with him.

Mr. Boardman was, it is believed, the second subscriber on the list of Folest and Stream when it was started in 1873, and from that time to this he bal taken it withont a break.

Hon. George F. Edmunds, United States Senator from Vermont

I can say with sincere gratification that so far as my acquaintance with Mr. Boardman went, I was strongly impressed with the extent of his knowledge, the purity of his character and his very agreeable manners.

Robert Ridgway, Curator Smithsonian Institution, Washington, D. C.

Although I saw Mr. Boardman but seldom, I nevertheless remember well his kindly face, his friendly and genial greeting and his bright and interesting conversation.

\section{G. Elliot, New York}

Mr. Boardman was a most careful observer and his statements of things he had seen were thoroughly reliable. Men like him are always rare and it is a pity that they are obliged to leave the scene of their labor.

Prof. William H. Dall, National Museum, Washington, D. C.

My knowledge of the late George A. Boardman was confined to personal intercourse with him at the Museum and at Prof. Baird's house on his way to and from Florida in the early years of my connection with the Museum. Like all who made his acquaintance I felt a sincere regard for him, his mild, kindly manner and consideration for those younger and less experienced being always manifest. 
Henry E. Iresser, London, Eng.

Mr. Boardman lived to a great age and lived an active and useful life and one cannot be sorry for his death but only for those who have lost him. It is now nearly 40 years siuce I last saw him at Calais, but it seems but yesterday, and I have a most pleasing recollection of the time I spent in his company talking over bird matters. He was a most excellent ficld naturalist and a keen observer, and to me who then was but a young naturalist he was always most ready to lend a helping hand as he was to any young fellow who was interested in ornithology or oology.

Among the honors conferred upon Mr. Boardman were the following: He was chosen a corresponding member of the Boston Society of Natural History, April 16, 1862. On April 10, 1863, he was elected a corresponding member of the Natural History Society of New Brunswick, St. John. At the first congress of the American Ornithologists' Union held at New York in September, 1883, he was elected an associate member of that body. He was also an honorary foreign member of the Zoological Society of I,ondon, Eng. On the occasion of the dedication of the new building of the American Museum of Natural History, New York, which was opened by President Rutherford B. Hayes, December 22, 1877, Mr. Boardman was invited as a special guest. 


\section{CHAPTER X}

\section{CORRESPONDENCH WITI NATURALISTS}

$\mathbf{M}^{\mathrm{r}}$

R. BOARDMAN was a voluminous letter writer.

His list of correspondents embraced nearly every ornithologist of note in this country, of the period when he was most active in his ornithological collections and studies, together with many in New Brunswick and some in England. He not only spent a great deal of time when at his summer home on the St. Croix in correspondence with his naturalist friends, but when at Florida during the winter he was a constant and frequent letter-writer. Not only this, the letters which have been examined that were written by Mr. Boardman show that when stopping in Boston, New York or Philadelphia for a day or two on his journeys to or from the south, he wrote many letters to his correspondents when at his hotel. If he called upon his scientific friends or saw anything new at the museums he was always sure to write half a dozen letters to his correspondents, telling them whom he had met and what he had found that was new. This was especially the case when stopping at his brother Gorham's in New York. Fiven when on his trips to the west and to California, as well as during his visits at 
Clifton Springs he was devoted to his correspondents and many were the letters he sent them, detailing the incidents of his trips, telling then what he had seen and inquiring for their well-being. In one instance he wrote a long letter to Prof. Baird while remaining in the railway station at Boston, waiting for a train. It was on December 18, 1875 and was in reference to obtaining a pair of moose for the Centennial Exposition at Philadelplia. He loved to remember his friends and was most happy to answer their inquiries or do them a favor. Moreover his letters were always familiar and interesting. He had the happy gift of saying pleasant things and writing about common experiences and observations in a most entertaining way, especially when writing to his most intimate friends. Systematic and careful as he was in all his business methods, Mr..Boardman retained the letters that were addressed to him and always filed them in the most orderly manner. Between three and four hundred letters addressed to him by his scientific correspondents and friends have been examined in the preparation of this memoir.

It has been difficult, however, except in few instances, to obtain many of Mr. Boardman's own letters. Those to Prof. Spencer F. Baird of the Smithsonian Institution; to Dr. William Wood of East Windsor Hill, Conn., to Robert Ridgway of the Smithsonion Institution, to $\mathrm{Mr}$. J. A. Allen of the American Museum of Natural History, New York, and to Mr. Charles Hallock of Jersey City, N. J., have, lowever, most fortunately, been obtained and made use of. A list of the naturalists with whon he was in correspondence and whose letters were preserved by Mr. Boardman other than those just named, 


\section{THE NATURALIST OF THE S'T. CROIX}

embraces the following well-known names: D. G. Elliot, A. E. Verrill, George N. Lawrence, T. M. Brewer, William Brewster, C. Hart Merriam, Charles J. Maynard, H. A. Ward, A. L. Heermann, Elliott Coues, H. A. Purdie, John Krider, A. Leith Adams, N. Clifford Brown, Everett Smith, Ruthven Deane, J. B. Holder and $\mathrm{L}$. W. Bailey. In addition to these scores of letters from lesser known naturalists as well as from local ornithologists and observers in different parts of the country, are included and have been carefully examined. With many of these last named Mr. Boardman carried on a regular although occasional correspondence, while scores of other letters were addressed to him by young naturalists who asked for instructions or by observers who wrote making inquiries upon interesting, but little understood, points in bird life, and upon which they knew Mr. Boardman possessed information. The letters of acknowledgment and thanks found among his papers are sufficient to show that all such inquiries were promptly and thoroughly answered. His kindness and helpfulness to young naturalists were proverbial among all his scientific friends - a fact to which these letters give abundant testimony.

Mr. Boardman's most constant correspondent in this country, as well as his dearest and most intimate friend, was the late Prof. Spencer F. Baird, for many years secretary of the Smithsonian Institution, Washington, D. C.

Spencer Fullerton Baird was born in Reading, Pa., February 23, 1823, and graduated from Dickinson College in that state at the age of seventeen years. In 1845 , at the age of twenty-two, Mr. Baird was chosen professor of natural history in Dickinson College, and five years later when only twenty-seven years of age was 


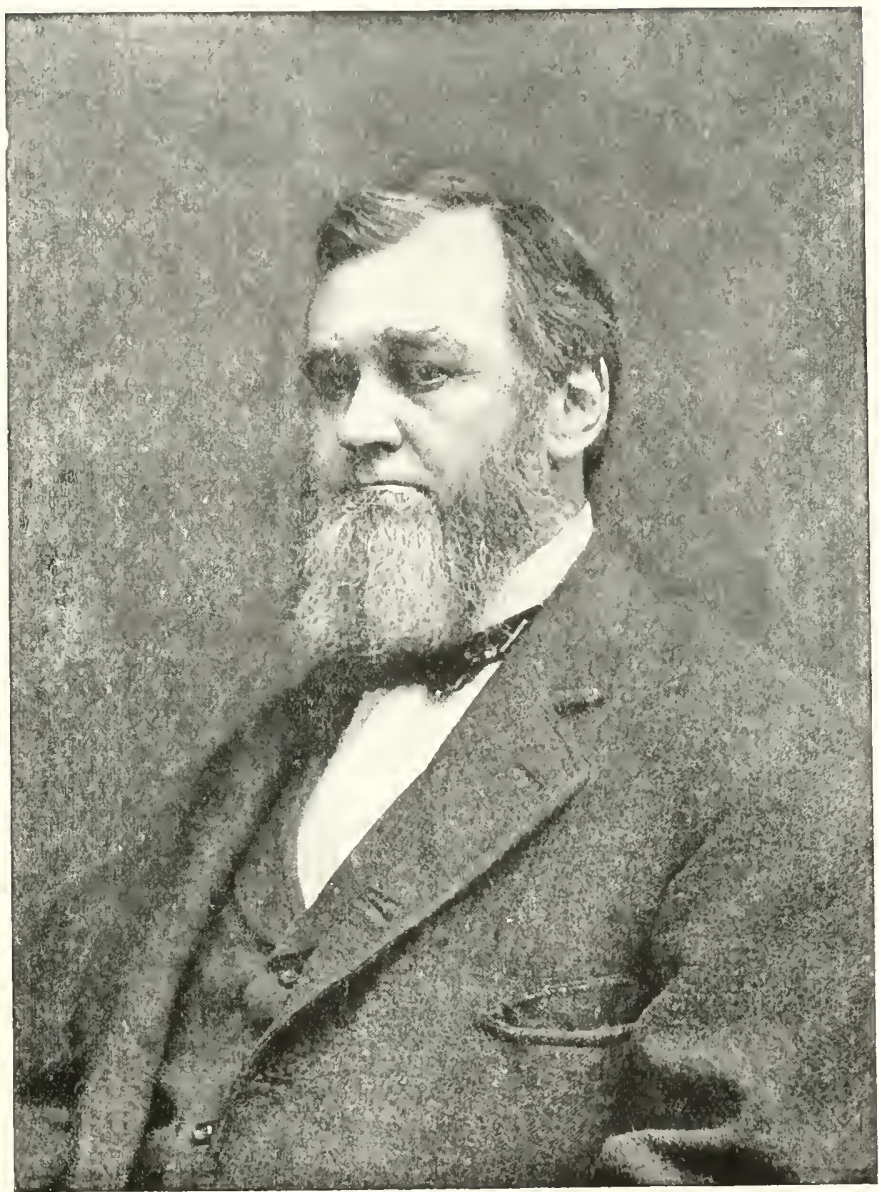

\section{SPENCER FULLERTON BAIRD}

Secretary of the Smithonian Institution, Washington, D. C.

$$
1878-1887
$$



appointed assistant secretary of the Sinithsonian Institution.

An outline of the scientific career of this remarkable naturalist would embrace the following briefly stated but distinctive periods of scientific activity: A period of twenty-six years devoted to laborious investigation of the vertebrate fauna of North America, 1843-1869; forty years of continuous contribution to scientific literature of which at least ten were devoted to scientific editorship, 1840-1880 ; four years devoted to educational work, 1846-1850 ; forty-one years devoted to the encouragement and promotion of scientific enterprises and the development of $11 \mathrm{ew}$ workers among the young men with whom he was brought into contact, 1846-1887; thirtyseven years devoted to administrative work as an officer of the Smithsonian Institution and in charge of the scientific collections of the government, 1850-1887; twenty-eight years its principal executive officer, 18501887 ; nine years secretary and responsible head of the Smithsonian Institution, 1878-1887; sixteen years United States Commissioner of Fish and Fisheries, a philanthropic labor for the increase of the food supply of the world and incidentally for the promotion of the interests of biology and physical investigation, 1871-1887.

Prof. Baird's published works embrace his History of North American Birds, five volumes, 1874-1884; the reports of the Smithsonian Institution and of the United States Fish Commission, while a complete bibliography of his works would embrace over one thousand titles, two hundred of which are to be classed as formal and elaborate contributions to scientific literature. With the publication of his quarto work of over two thousand pages on 


\section{THE NATURALIST OF THE ST. CROIX}

the Birds of North America, as one of the volumes of the Pacific Railway reports began what has been most appropriately termed the Bairdian period of American ornithology and the beginning of the work of the Bairdian school of naturalists - a period covering nearly thirty years, and one, says the late Dr. Elliott Coues, "characterized by an activity in ornithological research and a rapidity of advancement without a parallel in the history of science."

Prof. Baird was a keen archaeologist and originator of the National Bureau of Ethnology. He designed the government vessels, the Fish Hawk and Albatross, used in the service of the United States Fish Commission and was instrumental in obtaining from Congress the appropriation for the building of the east wing of the Smithsonian Institution. Royal honors were bestowed upon him by the governments of Australia, of Sweden and Norway and of the Republic of France; while he was elected to membership in ten foreign scientific societies of high renown. While in the discharge of his duties in connection with the Fish Commission, Prof. Baird died at Woods Holl, Mass., August 19, 1887.

The correspondence between Prof. Baird and Mr. Boardman began in 1862. Among Mr. Boardman's papers have been preserved nearly one hundred letters from Prof. Baird; while in the Baird collection in the Smithsonian Institution are one hundred and seventy letters from Mr. Boardman - all of which have been read with great care. The earliest letter from Prof. Baird bears date June 18, 1862 and the last, September 9, 1886. The first from Mr. Boardman bears date January 4, 1865 and the last, September 5, 1886, covering a 
period of twenty-four years. Between June 18, 1862 and September 12, 1868, there are eight letters addressed to Mr. Boardman in Prof. Baird's own hand; after that the letters are in the handwriting of his secretary, although signed by himself - except in case of one very brief letter dated at Eastport, Maine, June 26, 1872, and a somewhat lengthy postscript to a letter from Washington, November 1, 1869.

The first letter from Mr. Boardman to Prof. Baird found in the Smithsonian collection is dated at Milltown, January 4, 1865, which is in' answer to a letter for information. But earlier letters than this from $\mathrm{Mr}$. Boardman must have been written, as in his of June 18, 1862, Prof. Baird begins by saying: "Yours of June 13 is just to hand and I hasten to answer it." He says in this letter: "Any chicks of partridge, grouse and ducks will be very acceptable. Embryos in alcohol will also be desirable if well identified. I have never seen the egg of solitary sand piper (I want to very much!) but think it will be somewhat like that of spotted tattler, though larger." Writing from Carlisle, Pa., July 21, 1862, Prof. Baird says: "The bird you send is the female of the Black Poll warbler; possibly of the Baybreasted; but I think not. The females of the two can scarcely be told apart. I would like another dusky duck's egg very much indeed. Any certain eggs, however common, are always welcome."

In all the early letters to Mr. Boardman, Prof. Baird is telling him what they want at Washington and giving suggestions for collecting. November 19, 1862, he writes: "If you have the sets of eggs and nest of the three kinds of thrushes, with parents, I wish very much that you 


\section{THE NATURALIST OF THE ST. CROIX}

would send them in order that I may satisfy myself positively in regard to them, especially the spotted egg and busl or tree nests. We want very much a good specimen of the cinerous owl. A series of Jaegers, too, would be very acceptable as $\mathrm{Mr}$. Coues is now preparing a monograph of this genus. A young white-wing gull, too, we would like. Can't you send us some of those northern eggs you speak of? Where were they collected ?" November 23, 1865: "I would much like a good lot of good skins of the three-toed woodpeckers ; good crossbills ; Hudson Bay tits ; Canada Jays ; Hawk and Richardson's owls ; Acadian owl ; Pine Grosbeaks ; Pine finches, spruce and common partridges and the like, for our exchanges. What you gave me last summer have answered a capital purpose." May 20, 1868: “I am glad you have the Pied duck and have got us a specimien. Don't forget that it is the only North American duck not in our collection and next to Great A $11 \mathrm{k}$, perhaps our greatest desideratum among water birds. I can't ask you to send this one, but I speak for the next."

Writing from Beverly, Mass., September 12, 1868, after a visit to Mr. Boardman at Milltown, Prof. Baird says : "I cannot tell you how I hated to leave with all the projected trips incompleted. I don't know when I have had so nice a time and shall always be grateful to you and Mrs. Boardman, to say nothing of Charley and Georgie, for your kind attentions." On this visit Prof. Baird had become much interested in the shell heaps of the St. Croix valley and the many Indian relics, which, on subsequent visits he gave much time in excavating and studying. In the same letter occurs the following: "I really must have Pollice's spear if I have to get the 
United States district attorney to seize it as smuggled from old Indians without paying duty; or else as a Fenian weapon intended for invading New Brunswick. I will ask Prof. Henry to let me send you a lot of showy shells and birds to trade for this and other purposes. I hope you will find out all the shell heap localities and dig all you can; there will be plenty left for me to do when I come up again. I intend to make a specialty of this subject and want to work it out thoroughly. Note all you can about thickness and succession of beds; interpolation of gravel ; position of best remains," etc.

In a letter dated Washingto11, November 22, 1869, Prof. Baird writes: "Ridgway is now hard at work upon the North American hawks and is doing a good work. $\mathrm{He}$ finds a species like the European Merlin, but differing both from that and from the Pigeon Hawk. I will show it to you when you come. Write soon and let me know when we may expect you. I hope you will arrange so as to pay us a good visit on your way south." Writing to Mr. Boardman, who was then in Florida, January 27, 1871, Prof. Baird says: "The fish bill has passed the House and has a good chance of going through the Senate so that you may yet be called upon to furnish official information of what you know about fishes and you will please be prepared." To this letter a postscript is added from Mrs. Baird: "I send a handkerchief left here, thinking you may want it. - M. H. C. B."

"I would like very much," Prof. Baird writes from Woods Holl, Mass., July 25, 1871, "to 'knock off' work here and go with you up Princeton way to shoot young ducks; but I rather think I had better stick to my business the present summer, hoping that perhaps I 
may have the pleasure of the excursion next year." In a letter dated November 23, 1871, he writes: "I am much obliged to you for the potatoes and shall value them both for their own merits and for the kindness which prompted you to forward them. I only hope that you and Mrs. Boardman will help us eat some of them in Washington." 'This was after Mr. Boardman had sent Prof. Baird a barrel of potatoes as he had been in the habit of doing. He had, also, from time to time, sent firkins of butter and jars of raspberries. What a bond of union such gifts were between country and city friends in the good old days! Writing to Mr. Boardman in Florida, February 2, 1872, Prof. Baird says: "Yon must not apologize for routing us out so early on the day you left as it was by 110 means nnnaturally early and was not of the slightest consequence. As an offset I shall claim the right of doing the same thing some day at your own house-but if you talk too much about this it may prevent me from exercising this privilege." Again writing to him while in Florida in the winter of 1873 he says: "I do not at present think of anything very special in the way of birds, although we would be glad to have some skins of the Florida Jay, the Ivory Bill, the Red Cockade and Woodpeckers, Paroquet, etc. I hope, however, you will be able to secure some Limpkin eggs of which, as you know, we have only one and that from Cuba."

The kindly personal interest expressed by Prof. Baird regarding young naturalists and in all his friends, is shown in many letters. "The young gentleman from New Bedford," he writes to Mr. Boardman, October 10, 1870 , "who wants to go with you next winter is William 
92.92

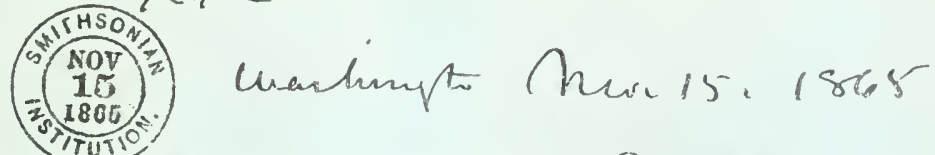
My leer And Ba adman your y Mu 10 is gust thanes

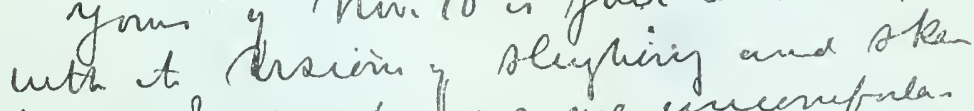
hons. 2 day hue we ne incerreforlas be warm for the season ard ham seances so for had Mo r lear l stein is dee. I warta I coed

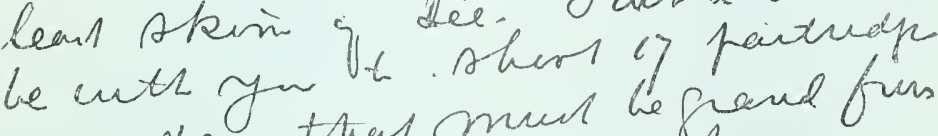
on a day: that mut he grand firs celled I an glad $t$ hear Fr are to well focused wits the

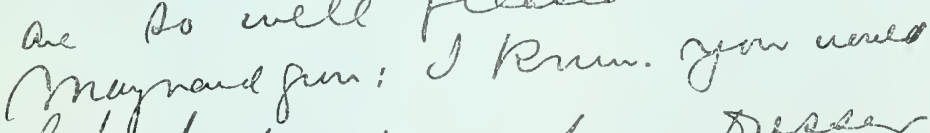

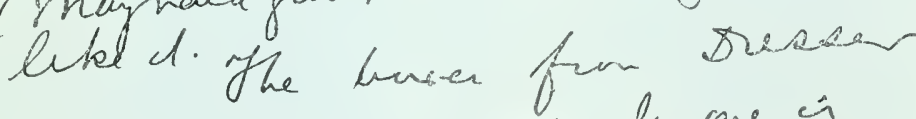
have nat fist canned to one in sens oibect thing or frost

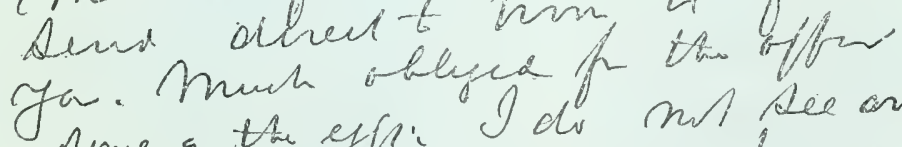
Deme o the effie. I do not pee any os the lift care about herren

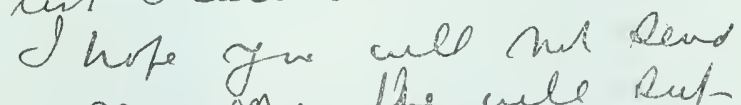
away any nine of p: the cull Rut ty nits wtrativer yon mad o much withe quale f. Rend w an g gand upu y on arlleet.

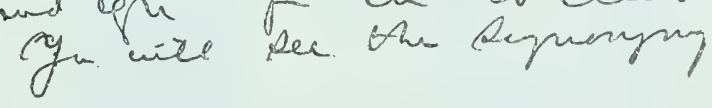



q Molusilla alha is my nu bovk. pist. It is not the comer wan hind to whech. Iyom off the une adused of 32 binas of Curta gf is thes foll: Vtten well not he hue horvener bile may or Leme.notgetteng $t$ BS. Paul thefre lintex.

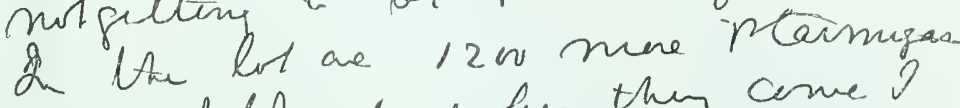
egf I thenc when then corve? nill dene for gow th help catialove thim: a cerrutendunt neer tide unnty achser eff i havblom gull: cresties frebe: hed head duele, et. all nuw this,

I mail you a whrle list enter Mat. Int fafan. Reliom any yow abready hews kep all yow have not Yow orght have the full Aelly Procedang the Acachomy ai whis Nare and many othis Patar apter 16 ircinns oul con $\$ 48: 00$

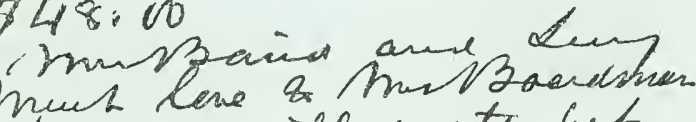
pene must lase \& ill wits befon lin. fobarama

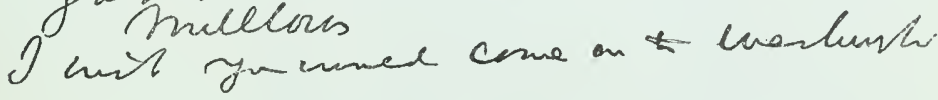



Nye. You will find him an excellent companion, perfectly able to look out for himself and to take his share of the hard work of the campaign." On May 3, 1872: "I am sorry that poor Krider has been so much afflicted in his family. I had heard nothing of his misfortunes." On May 21, 187t, lie inquires: "Who is Mr. Whitney and what does he do for a living?" and on June 3 of the same year says: "Many thanks for the information respecting Mr. Whitney. Can you give me any idea how long he is likely to stay in California and whether a letter addressed to him wonld reach him in time to secure some specimens." In this letter he also adds: "I am glad to hear that you are able to give Willie Bryant some help in his researches. I trust he will follow in the footsteps of his father so far as natural history is concerned." In a letter dated May 17, 1872, he says: "I am glad to find that you got home safely and that Mrs. Boardman is better. Perhaps if you will take her on your next excursion to Florida she will be less troubled with that heart complaint." In the very last letter that Prof. Baird wrote to Mr. Boardman, dated at Woods Holl, Mass., September 9,1886 , occurs this sentence: "I am glad of the prospect of getting the skin of the black lynx; it will be quite a novelty to us."

\section{Letters from Prof. Baird to Mr. Boardman}

iVashington, D. C., Nov. 1, 1869.

MY DEAR Mr. BOARDMAN :

Your's of the 25 of Oetober is duly at haud; and for a letter that might be presumed to give an account of a weddiug in the family, it has about as little reference to that subject as it well could. You do not tell us how the bride looked, nor the bridegroom, nor any of the particulars that the ladies especially are so 


\section{THE NATURALIST OF THE S'T. CROIX}

anxious to learm; and not the first bit of eake has, so far, come to hand. I suppose, however, you intend to bring your trumk full of it when you come.

Is it not about time for you to tell us a little as to your plans for the future, and when we may arrange for killing the fatted ealf for yourself and Mrs. Boardman and Willie? 'Tell Willie that Mr. Elliot is expeeted back in a few days; and he will have plenty of pictures to look at, as well as be making new ones all the time.

'The report you asked for, for Mr. Pollice, has already gone to him. Let me know if anybody else remains to be supplied. We have sent to Dr. 'Todd, to Simpson, and to Connor. Who else is to be remembered?

'The skulls of the Sonth African beasts are what we now want above everything else of that kind. Nothing would come amiss. Entire skeletons of course are most desirable; but single skulls, with the teeth and horns as perfeet as possible, including the lower jaws, will be very useful to us. We have one entire elephant sliull, I think it is South $\Lambda$ frican; but other speeimens, even single teeth, will be weleome. 'The rhinoceros we have not and want it very much. Nothing of the mammalian kind will fail to be acceptable.

Ridgway has not reached Washington, but will probably be here before long. His eollections are probably in our cellar, although $I$ do not distinguish any box as his, among quite a large number sent in by Mr. King.

I am glad you have the nest of the Goshawk, and hope it will reach us in safety. We want to procure such large specimens, as they can only be exhibited where there is an opportunity for giving them ample room, which ean be done in our museum.

We have already sent you three copies of the bird eatalogue, printed only ou one side; but if you want more let me know. We expect Dr. Brewer with Mrs. Brewer and Lucy to pay us a visit soon after 'Thanksgiving. 'The Dr. expects to make some big hauls in the way of eggs. I did not find much of speeial novelty here, on my return; very few eggs of any account, and only one case of birds from Bishop, embracing nothing new, and nothing very rare. Our Aretic collections, when they reach us, which will be in the course of a few months, will doubtless be full of 
interest. We laul from Willis the other day a box containing 350 regs of the Aretic 'l'em, and about 50 of either Sheldrake or Black Duck; and I wait your coming to determine which.

Yours truly,

SIPNCER F. BAIRI.

llow tho you like the preceding experiment of phomographic reporting* or have I tried it on you hefore? I fouml professor Ilemry quife ill on my return, and although hetter I have still to attend to most of his sham of correspendence so that I have been obliged to call in services of a reporter. It is very nice in some respects, as 1 ginin a great deal of time, and sometimes work ofl 40 or 50 letters in a couple of homs. It is however not quite satisfactory as you camnot tell when you are repeating worls or isleas unneessarily aml the chain of comnection is not so elear.

I an adding to the box for cheney and have just put in some shells for his wife.

Wasingtion, 1. C., Jan. 7, I871.

My DEAR Mr. BuARDMan:

Yours of the 4th eame to hand yesterday, and I hasten to say how happy we shall be to see you and Mrs. Boardman here. Give us word by telegraph, the morning you start, in oriler that we may be eompletely prepared for you.

I am much interested in what you say about the African animals. Please send on directly here all you ean beg, borrow or steal, and we will decile in regarl to their preparation. We shall have all that are eapable of it, suitably monutel for exhibition as specimens, making sliulls of any that will not suit our purpose. We expect a fisst-rate taxidermist here in the course of the winter, who probably will be able to do full justice to them. We do not want anything set up in our musem looking pretty well; nothing but the very best taxidermy will suit us now.

Camnot you get for us that big Wild Boar. It wight serve to stare out of countenauce some of our auimals of a similar nature

* 'This addenda - in Prof. Baird's own hand - to the letter of November 1, 1869, refers to its having been diclated to a stenographer, or to a "reporter" as he terms it, a form of letter wriling that was then new. 


\section{4 'THE NA'TURALIST' OF' 'THE S'T. CROIX}

that now roam in Washington undisturbed. So do the best you can for us, "and your petitioner will ever pray."

With inuch love to Mrs. Boardman from all of us, believe me, Truly yours,

SPENCER F. Baird.

My Dear Mr. Boardian:

Washington, D. C., May 9, 187 I.

You may be sure that we shall look out for the barrel of potatoes, and hope it will come before we leave. Our plan is still to get away to Woods Holl as early in June as possible, althongh the precise date is a matter of some uncertainty. I had a very pleasant interview to-day with $\mathrm{Mr}$. Whitcher, the Fish Commissioner of Canadi, and he proposed a good deal of joint work. He says if I will go to the Bay of Fundy next year he will be present himself, or by deputy, and will furnish on the part of the government, all necessary assistance in the way of vessels, etc., and we can have a good time overhauling the natural history of the fishes. 'This was what I had looked forward to, and was very glad to have him suggest it.

We have agreed to take the Moose that your boy sent Wallace, and the Caribou, at $\$ 75$ each, which he says was about the price of mounting; and I believe he has already been paid this amount, so that it will hardly be possible to have the one Brewster offers.

I suppose you have not seen Wallace's specimens so as to judge of their excellence. Ile promises to keep them on hand until we want them, which will not be until next fall.

Ridgway has painted up your Auk's egg and it will be sent on very soou. I will put it in the same box with that little duck that has been here so long, and forward it in a day or two to your brother Gorham. Ridgway has just returned from New York, where he has had a very good time. He is very much iuterested in the Central Park.

I hope those Moose skeletons will be forthcoming, as we have lately had inquiry for Moose bones and were unable to exhibit them. Love to all.

Very truly yours,

S. F. BAIRD. 
Woows Hol., Mass., July 17, 1871.

My Dear Mr. BOARUMan:

I am delighted to hear that you have at last succeeded in getting for us a slieleton of the Moose; and write to ask you to forward it by some vessel loaded with lumber and bound for Washington. If you can send it to the care of our friend Mohmn it will be well, as he is very clever in such matters. l'lease let me know the bill of expense, in order that I may send it to Washington aud have it paid. It is of no conserneuce whether or not the skeleton reaches Washingtou before the middle of October, or even later.

I am glad you sent the Labrador Duck to Wallace to be mounted for us. I enclose a let ter received from Cheney in regard to a strange duck which 1 camnot make out; can you give me any suggestion in regard to this?

I am not at all astonished that Dresser was not satisficd with the California book, either as to the descriptious or the biographies.

I flatter myself that the new work will be a totally diflerent aftair, and that in it he will find all that is to be known in regard to the habits, as well as descriptions of our American species. 1 an glad to have information in regard to Allen's movements, which I have not previously known. Ile will undonbtealy make a magnificent collection of all sorts of things. Could you not get Capt. Treat to save for us the jaws of the sharks he takes and throws away this summer? That will give mo a clue to the species, and should I get to Eastport next summer I shall then arrauge to make a more complete collection.

I am hard at work here, studying up the fish, and have already collected quite an amount of valuable information ou the subject. If you come to Boston before September, I wish you would ruu down for a few days and see us here.

Very truly yours,

SPENCER F. Baird.

My Dear Mr. Boardman:

Washington, D. C., Feb. 17, 1872.

Yours of the 11th has just come to hand with its effectual disposition of the question of the Coontail cat. I am not at all surprised at the result, I am glad to find the question set at rest. 


\section{THE NATURALIST OF THE ST. CROIX}

I envy you your trip up the St. John in the little steamer. Don't you think you ought to have a dredge along and do what you ean in scraping the botton on the way? I shall be glad to have you secmre the alligators refered to; and hope yon will get at least one. Dr. Brewer came last night and will remain until some time next week. Ile brought that undetermined nest and egg that you collected last year, the female parent of which was deseribed as like a female bobolink. We have been looking over the matter, however, and have come to the conclusion that it is a I'ine grosbeak. I have, aceordingly, confiscated the specimen, in the interest of the Smithsonian Institution, and intend to hold on to it.

1 wrote to Bickmore about that Labrador Duck and told him we woukl be very glad to have it for the Smithsonian. He writes in leply to know what we will ofler the Museum of Natural llistory for it. I then responted that if he chose to put the intercourse between the Smithsonian and the New York Mnseum on a strict exchange, quid mo quo, it was all right, but it was not exactly the way we were in the habit of treating such institutions; that it had been our intention to give the Museum a first-rate series of our duplicates without any consideration of the question whether they could give any exchange; but if he preferred the other plan 1 would send him a list from which to make a selection. 'This would be rather a poor way of doing business for the Musemm, as we have so much more to give than they have to returu.

Give my kind regards to Prof. Wyman and tell him 1 hope he will stop, in Washington on his return and see us.

Very truly yours,

SPENCER F. Baird.

Wasmington, D. C, Mareh 9, 1872.

My Dear Mr. BOARUMAN:

Yours of the $3 d$ is safely at hand, and I envy you the nice time you are having in Florida. I hope you will come back full of treasures and ready to share them, as ever, with the Smithsonian.

I am happy to say that we are in possession of the Labrador Duck, a very nice specimen which arived yesterday. A week or two ago I wote to Biekmore asking whether he wished the 
relations between the Smithsonian and the New York Museum to be put on a strictly commereial basis; and I received a private letter from Mr. IIanes, who in some way had heard of our correspondence ant who disavowed any such ideas of a quil pro quo as Mr. Bicknore seemed disposed to establish, and said the Museum would be always happy to grive the lnstitutiou whatever they had to spare. Shortly after liekmore wrote stating that it gave him much pleasure to senu the specimens; so that I suppose be had received some sort of hint from the committee.

We have nothing new since the date of your last letter axcept that collections of one kind and another are coming in; and we are lard at work trying to keep matters in good condition. We shatl send ofl Mouday the Moose skeletons to Ward to have them mounted and prepared in his best style.

Ridgway is here harl at work at the Water Birds, and we have abont 120 pages of oul new book in type, thongh the work goes on rather slowly. With much love from all onr people I renain,

Sincerely and truly yours,

SIENCER F. BAIRD.

MY DEAR Mr. BOARHMAN :

EAsTPORT, July 17, 1872.

I want to come "1], before a great while, aml pay yon another short visit; but cannot quite see my way clear to do it just now. I write, however, to say that we hope, as soon as the Revenue Cutter is finished to make the long talked of trip to Grand Manan, and we shall he glad to have you aud Mrs. Boardman ready to join us in the excursion. Mr. Cheney was over here yesterday, and I arranged to have him in readiness to take us around when we go.

On Monday last, the Senator, Mr. Paine, Capt. Treat and myself went up to visit the pond, not fal from Robbinston, into which the eaptain had put in number of salmon fifteen years ago, and where the fish had been reported visible on several occasions. We took with us a large salmon net and set it in the lake but eaught no fish. Many of the neighbors, however, assured us that they lod seen huge fish, of from ten to twenty pounds, jumping 


\section{THE NATURALIST OF THE ST. CROIX}

out of the water. We had a delightful excursion and returned yesterday in good condition.

Please let me know the amount that yon advanced to French for the Grand Iake Stream expedition. 'This, I presume, eost considerably more than the first estimate; probably somewhere from twenty to thirty dollars. Of course this is a matter of no consequence, and I only ask that I may not forget to pay you when I see you.

Mayuard made his appearance last week and went to Grand Manan the next day. Cheney says that he and Ilerrick are collecting a great many birds. Herrick, among others, has several hundred skins of Petrels. I wish you would see Mr. Eaton again and find ont whether lie has sold the engine of his steamer, or whether she is available for my use. If he proposes to rent her to me I would like to have him give me his terms in writing so as to form the basis of a regular contract.

Verrill has not yet arrived, but I expect him every day, aud presume that the steamer will be needed by the end of this week or the beginning of next. As I understood Eaton he would furnish the boat, with an engineer and attendaut, and coal, for $\$ 10 \mathrm{a}$ day, and that, possibly on carcfully considering the matter, he might be able to put it at a somewhat lower figure.

Very truly yours,

Spencer F. Baird.

My Dear Mli. BoARDMan :

Eastrort, Ang. 29, 1872.

I went over to Grand Manan last Friday, and spending the night with Cleney, started Saturday morning for McLaughlin's, where we remained till yesterday morning. 'The object of my excursion was especially to talk with MeLaughlin about hering, and see for myself the spawning ground. I had a very pleasant visit, barring two days of fog and rain, and was accompanied by quite a number of young scientifies. We did considerable dredging and obtained numerous curions objects.

On my return I find your letter of the 26th with its enclosure from lírider, and am much obliged to you for the opportmity of knowing what he is about. I hope he will send you the egg of the Solitary Sandpiper; as, if it is a genuine one, I will manage to 
steal it from you. Ile is rather shy now of giving anything to the Sinithsoniau.

It is now so late in the season, and Verrill will leave so soon, that it is hardly worth while to do auything more with Mr. Eaton. I think that with the help of the tug we eould have done a good deal more work. Still it would have cost three or four hundred dollars of my appropriation, which I can use to better advantage. Mr. Gill has been liere a week, and leaves today. IIe was with me at Grand Manan, and saw a good deal that interested linu.

We are sorry to leain that Mrs. Boarduan is being taxed so much by the sickuess of your relatives, and hope she may soou be relieved by their recovery. Is it not almost time for some of you to come down to Eastport? It seems a great while since we were together.

$$
\text { Very truly yours, }
$$

S. F. BAIRD.

My Dear Mr. Boaroman:

Wasilington, D. C., Nov. 20, 1872.

Your letter of the 15th and the accompanying Chick of the Canada Grouse cause safely to haud. The latter will be at once figured for the fortheoming book.

I was glad to find from Dr. Brewer that he did not consider his loss irrepurable, and hope he may soon recover all the old ground. I shall look to see you, according to your letter, towards the end of December; and hope to be able to make your visit to us a pleasant one.

I woulh be very glad indeed to have the first pair of Caribon skeletons, male and female, to be got and pay whatever they are worth. I also would be glad to have a pair of skins, and would like a first-rate hend with them; also, if it is possible to get a good female moose skin, I would like it, so as to complete our series of large animals. We have just received from Prof. Ward the skeleton of the moose you sent, and it is perfectly magnificent in its general appenance. As we have the Irish Elk and common Elli, the three make a fine series. We have a man permanently employed who ean beat Wallace all to pieces. Ile is the same person who mounted the head of the buftalo we have. 


\section{0}

THE NATURALIST OF THE ST. CROIX

Mrs. Baird has just gone off to make a visit at my sister's and would send love to Mrs. Boardman if she were here.

Very truly yours,

SPENCER F. BaIrd.

Washington, D. C., Jan. 16, 1873.

My Dear Mr. BOARDMAN :

I was very sorry indeed that I did not have the pleasure of seeing you on your way Sonth, and if I had lad any idea of the train to look for I should have been at the station and seized you.

Our smallpox scare is about over; as, although our neighbors have been kept in strict quarantine, there has been no additioual development of the disease. We have not had any apprehension of it for some days past. Your letter was delayed, reaching me too late for me to write or telegraph to Philadelphia; otherwise I shonld have sent you a despateh asking yon to stop. I hope, however, we shall not be cheated ont of a visit from yourself and Mrs. Boardman on your return.

I camnot imagine what Kirider's hawks are mless they be the California Rough-Leg. Did you notice how mneh feathering there was on the feet? 'These are bare about as mueh as the common partridge, the feathers not reaehing down to the toes. I would endeavor to see the birds if I thonght lirider would show them to me, but he has been so sliy of showing anything to me that I have not eared to bother about it.

We have received quite a number of nice things from Elliot and Dall, among them eggs of two species of Phaleris, the RedLegged littiwake, the Gray Auk and some others, eight or nine in number. It is no small thing to get so many new water birds at one lot. Among the series was the egg of Steller's Duck.

With love to Mrs. Boarduru, believe me, Sincerely yours,

\section{SPENCER F. BAIRD.}

\section{Wasington, Mareh 8, 1873.}

MY DEAL MR. BOARDMAN :

We were very glad to get your letter of the $3 d$ and to know something of your whereabouts. I was beginning to feel quite uneasy about you, fearing that some suipping turtle or alligator had gobbled you up. 
You give us a very tempting aceount of a Southern Spring. 'Jhis would have becm in greater contrast with our own if we had received it on the day of Inanguration. 'I'his was exeessively cold and bitter, and eansel great disappointment to the thousands of strangers who came in from all parts of the comntry. 'There was a ball in the evening in a new bulling erected fol the purpose, 350 feet by 159, and it was so cold that the guests wore all the wrappings they conkd gather together, and they had to chop up the chicken salad with hatchets to get a chance to eat it. It was so cold that it is sajl the breath as it rose into the air gave the appearance of a company engaged in smoking.

If you will keep a sharp lookout for the time of blooming of the Cereus plant, and let me know when this comes off; I will come down and see the phenomenon.

When I went through Philadehphia a few weeks ago I stopped and tried to see Krider"s hawks, but Jooper had them in West Philadelphia, and $I$ coukl not get a sight at them.

From the description 1 infer that they must be a variety of Swainson's buzzard. I cannot believe in the existeuce of a new species of so limited distribution.

Very truly yoms,

SPENCER F. BAIRD.

We are begimning to look forwad to a visit from you on your way home. We feel as if the smallpox hat cheated us out of onf risit to which we hat a right.

N. H. C. B.

WAsHington, Dec. 30, 1873.

MY DEAR Mr. BOARDMAN:

Your letter of the 23d was duly received, together with the specimens therein advised, and we were especially pleased to get the Whitefish, as enabling us to form some idea of its eharacter. It appears to be esseutially the same as that common in the St. . John River and known there as the Gizard fish, although it is quite dillerent from the Whitefish of the western lalies.

It is quile impossible to say whether the young fish are landlocked salmon or sea salmon, especially as noborly has bcen able to point out a charater sufliciently marked to distinguish them. 


\section{THE NATURALIST OF THE ST. CROIX}

'The pigeon is one of the West Indian speeies, the name of which 1 have not identified.

Any time that you have anything else to send please forward the Florida fish.

With love to everybody, believe me,

$$
\text { Yours truly, }
$$

S. F. BAIRD.

Washington, April 17, 1874.

My Dear Mr. Boardian:

I lave been wondering very much what had become of you, and only learned incidentally from a gentleman who met you in San Francisco, that you had actually gone to California. I am glad to know that you are having so good a time, and I trust that you will eome back in first-rate health, with lots of nice specimens and enough for your friends. I have nothing very novel to communicate in regard to our doings. We are progressing in the old humdrum manner, steadily adding to our collections, without anything very startling. I hope, however, that the coming season will be equally prolifie with the last in birds and their eggs, of which, by the way, yon onght to be able to pick up some nice ones in California.

'The govermment expeditions are getting ready to go out although the appropriation bills have not yet passed. Dr. Coues will donbtless get into the cast section of the country and will probably add largely to his lists.

Mrs. Bryant's youngest son, Willie, seems to inherit the zoological tastes of his father, the doctor; and in reply to her incuiry as to a good locality for the spring, I have advised her sending Willie up to Princeton with his attendant, there to hire a couple of Indians and look up birds' nests. Mr. Frank Carryl of New Jersey proposes to follow quite a similar route.

My appropriation for the summer has not yet passed, but I bope to be able to go to Noank towards the end of June, where I trmst I shall have the pleasure of a visit from your.

Very truly yours,

S. F. BAIRD. 
MY DEAR MR. BOARUMAN:

Noank, Conn., July 25, 1874.

'Thanks for your clever letter. As to the nest of the Pileated Woolpecker, if you do not disturb it at all, nor the old birls, they will in all probability nest in the same place next season, and by a little judicious manoenvering, by taking out one egg at a time with a spoon, they may yield a dozen egors as the Piedheaded Woodpeckers and the Golden-winged do under the same circumstances. It would he a gramd thing if you conld get about a dozen eggs from this one nest.

We are having a very good time here, and our party has met with success quite equal to our expectations. 'The dredger's go out every day or two, and bring back lots of nice things. 'The fishes are also interesting. Dr. Palmer is still in Florida; but I have a very good substitute for him. Luey is still at North Conway where she is having a good time.

Very truly yours,

S. F. BAIRD,

West Philaibliha, Pa., Sept. 13, 1876.

My Dear Mr. Boaruman:

Yours of the 10th is to hand. I am happy to say that the pleasant weather has greatly improved the comfort of the exhibition and that we are all doing pretty well in consequence. I hope you will not fail to carry out your intention of coming on in October.

If I were you I would not sell my pair of Labrador Ducks at any price. Sometime you will probably want to give or sell your collection to some institution and the including in it of a pair of Labrator Dueks will add greatly to its value. Under any eircumstances do not lint at a less price than $\$ 200$ or $\$ 250$ in gold for the pair'. 'T'here seems to he a fancy for Labrador Ducks, and you eau get that as well as not. I would not sell them for a cent less. You may be able to get another female, but it is doubtful in regard to a male.

Mind what I say about the price. 'lell him that you do not want to part with them, but that they are worth the amount mentioned by me.

Sincerely yours,

S. F. BAIRD. 


\section{4 'THE NA'TURALIST' OF THE S'T. CROIX}

Dear Mr. BOARIMAN :

Wasington, D. C., Nov. 27, 1878.

Yours of the 2fth is to hand. I was in hopes you would begin to say somethiug about coming sontl. Will it not be a good idea for you to spend the next winter here as you did the last?

I have a great deal to tell you about adventures and experiences at Gloucester during the summer, and of explorations, aretic and otherwise. One of the best thiugs obtained on the Banks was the skin of the great Skua Gull. We obtained all the Jaegers, as also the Dusky Puflin, ete. Send on the specimens whenever you ale ready, and eggs as many as you please.

With love from all of us to yourself and Mrs. Boardman, believe me, Sincerely yours,

SPENCER F. BAIRD.

Wasilngton, D. C., Dee., $18 s 4$.

Dear Mli. Boaliuman:

Your lettel of the 18th is to hand. Mr. Ridgway was quite enthusiastic in regard to the Florida Pigeon Hawk, and is much obliged to you for saying that he might place it in the Museum. The next time you go, try and get some more.

I hope Albert will be able to get one or more skins and skeletons of the 'Trumpeter Swan; they are apparently getting very scarce.

Several white Whooping Cranes would also be very nice. 'They could easily be sent in the flesh in the cold weather; but if necessary they might be skinued and poisoned, and sent with the skins green to he mounted here.

What is the latest Fish Commission and Snithsonian lieport you have received? lioth volumes for 1882 have been published.

None of Nelson's reports have appeared.

'Turner has got back from labrador with some nice things, but nothing startling.

We are just having a very severe cold suap. 'The thermometer was nine above zero, which we considered pretty sharp. I do not think we had such cold weather last year.

With warmest regards from everybody to yourself and Mrs. Boardum, I remain, Sincerely yours,

S. F. BaIrD. 
During the first year of their correspondence, 1865, fonrteen letters were written by Mr. Boardman to Prof. Baird. The period of greatest activity in the correspondence between these friends was during the years 1868 to 1880 . In $1868 \mathrm{Mr}$. Boardman wrote eighteen letters to Prof. Baird ; in 1869, forty-two ; in 1870, twenty-six and in 1875 , sixteen. 'These letters are in the most familiar language, all are interesting and nearly every one contains more or less notes about the birds he had observed and studied. There is not a letter within the range of the entire correspondence that does not close with remembrance to "our scientific friends" and "much love to Mrs. Baird and Lucy." Prof. Baird must have been happy to have received these entertaining letters. He made special request for them. As late as $1880 \mathrm{Mr}$. Boardman began a letter November 3, by saying: "I am afraid I have not come quite up to your order to write every month as it must be more than that since I have written ;" while on December 29, 1882, writing from Minneapolis, Minn., he commences a letter witlı: "Some years ago you told me I must write you every month. I do not know how long that order was to last and think I have not observed it very well." 'This was seventeen years after their correspondence commenced and how dear and rich had been the intercourse and correspondence between these two friends! It was but two years before Prof. Baird's death and shows how intinate and constant had been their friendship and work even though the period of their activity was nearing its close. Its end only came with the death of the great scientist.

While scores of entire letters are devoted to ornithological matters there are in all the others references to his 


\section{THE NA'TURALIST OF THE ST. CROIX}

favorite study which make all Mr. Boardman's correspondence of value. From Milltown, N. B., he writes May 5, 1868: “I got a nice nest of Goshawk's eggs yesterday, with the old female - the first I ever found with the old parent. I am trying hard for the Saw-whet and Richardson's Owl eggs. They ought to be found as they are not uncommon all summer in the woods. I hope you may soon get your arctic boxes and find some new and good things. The warblers have got along and hundreds of birds have perished by the cold." On June 10, 1868, writing from Boston he says: "I brought up a Pine Finch nest and eggs, also a Canada Jay's to Dr. Brewer, as he wants to figure and describe them." " If you have any northern skins that would help my collection," he writes October 12, 1868, "please put them in when sending the box - say a good summer plumaged Old Squaw, Bonaparte Gull, and that I may compare it, one of those Barred Three-toed Woodpeckers and Hawk Owl," etc.

Mr. Boardman became an expert taxidermist and his mounted birds, skins and eggs always looked more artistic and in better condition than those of any other collector of his time. He always had better success in obtaining rare specimens than most other field naturalists. Writing from Jacksonville, Fla., March 12, 1869, he says: "I worked hard to get the Florida Jay on the old Smyrna road where Dr. Bryant always found them. I managed to get about a dozen but no otlier collector got one except Allen, who had but one. I had to let a few of them go for friendship's sake. I have also about two dozen Mocking Birds and quite a good lot of Redcockade Woodpeckers."

Writing from Boston, May 28, 1869, he says: "I notice what you say about the Towhees. We do not 
have them at Calais so I was not acquainted with them. I shot several last winter and think their eyes were all very light. One shot at Jacksonville had light eyes. I an anxious to get home to look after birds' eggs as it will soon be time for Warblers to nest." "I am glad," he writes from St. Steplen, June 12, 1869, "you have the Great Auk in your collection. You must try and get bones enough this season to set up a good skeleton. There should be plenty of bones at Grand Manan." On August 1 of the same year he writes: "I got a new bird for my list last week, a Black Vulture, Abrata. I got C. Aura about eight years ago, but Atratus I never knew so far north as cold New Brunswick before although I have known of several to be taken in Massachusetts." In this same letter he says: "I also got a duck I did not know this spring, but think it was the female Labrador Duck and nothing new only I dich not have one, which helps out my collection. A week ago last evening after tea, we took a canoe and went up stream a mile or two and I shot six Black Ducks and one Wood Duck - pretty well for after tea with ladies in the boat talking."

"Yesterday," he writes on September 21, 1869, "I shot some Sparrows, one of which I think was Lincoln's Finch but am not sure. It looked very much like a Savannah Sparrow except the yellow across the breast." On October 1, 1869, after Prof. Baird had written him about this specimen he again writes: "I cannot well send the Finch as it is monnted. It is a common Sparrow that I have always taken for nice specimens of Savannah Sparrow, with yellowish breast. If Savannah Sparrow does not have the yellowish breast it is probably the Lincoln Finch. I have one or two skins of the Savannah 


\section{8 'THE NA'TURALIS'T OF THE S'T. CROIX}

Sparrow that were marked by you which do not appear to have the yellowish shade to the breast, but the feathers of the tail are alike. There are lots of those little Autumnal Warblers about the house. I suppose they are the young of Black Poll - they are very abundant. I have shot half a dozen to see if they were alike."

" The Goshawk's nest is in very good condition and I will send it. I have no doubt Dr. Brewer will have a nice visit. Give him all the eggs he wants if he will only finish up another part of his Oology - ten or twelve years for a part is slow business. He must hurry up or we shall all be dead before we know anything about eggs. I am sending some things to Wallace. I want to get a few Deer or Caribou heads fixed to give away. I only want a few but I want good ones; I don't like so much trash." Writing December 18, 1869, he says : "I add three birds new to my list this year - Florida Gallinule, Purple Gallinule and Black Vulture. I also hope to add Lincoln's Finch, but I cannot tell till I see your specimens. These were taken at Grand Manan." Writing from Milltow11, July 26, 1870, he gives this description of a new duck:

I told, ol wrote you, some years ago, of shooting several small ducks I could not understand; I concluded they were in young plumage and did not save them. Saturday I shot one female in full plumage, as she had with her a flock of nine chicks. When I shot her, I thought it a Wood Duck or 'I'eal, and only shot one chick, as I did not suppose it was anything new. I have mounted the old duck and chick, and wish you could tell me its name; I have not looked at any books for its name as I don't know where to look. Its size is about the Ruddy Duck, perhaps a little smaller; its back, sides and breast a very bright ruddy brown, its neck mottled a light white and browu and looks gray, head darker, 
throat light and lighter from the eyes to the bill; bill wide like Ruddy, but not so wide, and no turn up to the end - feet not so large as the Rucldy, spot on wing about the size of Teal, dove color or lavender edged with white, the white very narrow, under wings white, tail dark, the under feathers white and brown, belly gray mottled with brown. I don't think it any cross as it had a flock of young and I have shot half a dozen years before; its eyes light hazel. Now dear Professor 1 have not found a new hird for my list this year and I want this bird to be a red breasted 'Teal, or some rare stranger as I have no doubt you will call it, you are so clever; you will laugh at the description, but I don't know any little duck whose wife it should be. It is not a Ruddy Duck, or Buflled Head, Green Wing or Blue Wing, and not larger than either. I must try to get the male, if I get time to go up again, which I hope to do before long.

It is about this specimen of which he writes to Prof. Baird from Boston, August 29 of the same year, when he says: "I left the little stranger with Dr. Brewer. If it should be the 'Tufted Duck it will be something new to add to your book as breeding in Maine and I hope you may describe it better than it has been done in the ninth volume (Pacific Railroad Reports) or by Audubon." On May 1, 1875, writing from New York to Prof. Baird Mr. Boardman says: "I spent most of the day yesterday at Central Park to see the boxes of New Zealand bird skeletons opened. They were all mounted and we set up two - they are monsters. 'The legs of the largest were just at the top of Elliot's head. You must see them. They have several duplicates, not quite entire, which the Smithsonian should have. I asked for them for you but got no answer, only that they should not sell them to Ward or any other speculator. At Philadelphia, where I spent two days, I called on Krider who left for northern Minnesota for a couple of months' collecting, 
the same day I left for here. He showed me his Solitary Sandpiper's eggs. I think they are not the eggs of the Spotted Sandpiper. They should be larger to be those, but instead were smaller and darker than those of the spotted. He said he had some for me but I did not get them."

"I have not wuch to report so far this year in natural history," Mr. Boardman writes on June 14, 1875, “only that I shot one Cedar bird with the waxen tips and bright yellow instead of red. I have been on the lookout for more eggs of the Ring-necked Duck. 'There are four pairs breeding at Kendrick's lake but I cannot as yet find the eggs. I was also told of some large Plovers breeding at St. Andrews island and engaged a man to try and find the eggs, also to be sure and get the birds. He sent me a nice pair of Black-bellied Plovers which looked as if killed with a club. The female had laid but I have not heard whether the eggs were found. I have never known this bird to breed with us although Wilson and Audubon say some breed in the United States." Writing from Jacksonville, Fla., December 30 , 1875, he writes: "When in Boston I heard of a Black Robin taken at Plymouth. I saw two persons who saw the bird in a cage. I at once wrote to Mr. Joyce, a bird shooter, who does considerable shooting winters and enclose his letter. I tried to follow this Mr. Baldwin, the owner of the bird, to see what became of it, but could not find where he went from Plymouth. Dr. Coues wanted me to make a record of any small birds I could hear about in black plumage."

Notes found in letters of 1878 are: June 21: "I got a crow with a very long, slender beak, fully three-fourths of 
an inch longer than usual. The boys reported a crow having quite a musical note - nothing like the old-fashioned croak - but a neat trumpet sound. After getting it I concluded the different note was caused by its beak in some way being of such an odd length. I have him now, mounted." July 27: "I found a queer looking eel at a fisherman's at Calais a short time ago, caught in the river near the ledge. Not having any good reference book on fish I do not know its name or if it is worth sending to you. It may be what is called the American Conger Eel, Auguilla oceanica, De Kay. It has a queer head and in color is very prettily spotted; colors very bright and yellowish; size about the same as the common eel. I put it in alcohol and will send it if you cannot make it ont from what I have said. It may be conmon but I have never happened to see one like it." August 11: "For the last two weeks the river and bay have been full of little Gulls. I have had lots of them killed but not one is Sabine; perhaps they do not come along so early in the season. I will have some of my gunners looking after the Ross Gull this winter."

"I have been at work in bad weather this winter," Mr. Boardman writes on January 22, 1879, "in the bird house - the first real clearing out for several years. I sent your big box away and put up parts of it so long ago I hardly know what is in the smaller boxes in itbut they are bird skins, eggs, etc. Have Mr. Ridgway examine the large white Goose that was shot flying with Canada Geese at Mace's bay near Point Lepreanx. I heard about it and sent to St. John for the bird, thinking it must be an albino, but conclude it must be a tame white goose that went away with the wild birds. 


\section{THE NATURALIST OF THE ST. CROIX}

Also look at the long-beaked Crow that made such a singular note." With this letter is a note asking Mr. Ridgway to ascertain the contents of the boxes that the gift may be properly entered. Mr. Ridgway's report is: Six mounted specimens; nineteen skins; eighteen eggs; one skin of fish from Florida and one Corvus americanus with malformed bill. April 26, 1879: "I was out in the pasture this week and found the snow quite deep. Saw a common striped snake sunning himself on the snow. It was very active and I ran it over the snow for some distance, when it went into a brook and after a moment or two went under the water and remained there apparently disgusted with the looks of things this time of year. Is it conmmon for snakes to be out on snowshoes?" September 8, 1879, Mr. Boardman writes : "We have had a great flight of new birds migrating of late-a large flock of Razor-billed Shearwaters, seven of which were killed; also a black Tern, new to me and a very pretty White Heron. I also had a Black Vulture sent me and heard of a Turkey Buzzard having been killed at Grand Manan, but I do not know the species. The laughing gulls have been very numerous about the islands of late, most of them young ones." In a letter written September 16, 1879, he says:

I noticed what you say about sending the skins of the Black Tern to Mr. Ridgway for identification. I don't think there is any trouble in making them out as they were all three old birds, one in full dark plumage, two in change, the white feathers all coming through about the lower parts; but I had another bird sent me I could not make out, a new bird to me; it may be a Gull-billed Teru as its bill was more like a Gull's, tail forlsed and long wings like a Tern. None of my books described it so I could not be certain. I sent the skin to Mr. Ridgway to name about the 
time I wrote you, but have not heard from him. 'lhe bird was about the size of Sabine's Gull.

I had the tail of a very large 'Thresher Shark sent me a few days ago, and heard of a very large shark being stranded at Campobello; sent down word to know about it and heard it was a Basking Shark, thirty feet long and as big around as a small schooner, so kuew it was too large to send you in a can of alcohol.

“ I have heard from Mr. Ridgway,"' writes Mr. Boardman on September 26, 1879, " and he says the skin I sent was Gull-billed Tern as I expected. It 111akes a bird new to my list. I had a White Heron sent me last week that was killed at Grand Manan and yesterday I mounted a Black Guillemot in change of plumage white and black. I also mounted a Coot which is quite rare with us."'

During the year $1880 \mathrm{Mr}$. Boardman wrote most interesting letters, extracts from some of which are reproduced. February 2 : "Since I wrote you I have had some skins sent me from Indian Island, near Eastport, among which was that of a Stonechat shot August 25. I have heard of its being taken before but never got one, this making four birds new to my list last fall, riz: Little Black Tern, Marsh or Gull-billed Ter11, the Razorbilled Shearwater and Stonechat." November 3: "I secured a nice specimen of Golden Eagle on the meadows at Milltown, week before last. I was out snipe shooting when a big Blue Heron rose and flew a short distance, then dropped as if it had been shot. In a moment the eagle came like a meteor, struck the heron so as to upset both birds and in the excitement I got the eagle with number six shot. They are very rare with us. I never got but one before this. I also got a couple of little Yellow Rails and heard of one having been killed at the 


\section{THE NA'TURALIST OF THE S'T. CROIX}

Grand Manan lighthouse." November 22: "I had last week a very large Raven - twenty-seven and one-half inches long and four ponnds in weight. I never had so heavy a one. I have only heard of one Snowy Owl being seen. I send you a little fish which Mr. Wilson got for us as he thought it a strange fish. I do not care to say what I think it is until I hear from you as G. A. B. is not a very good anthority on fish and I want to get Mr. Wilson interested in saving anything strange so I can send it to you for identification." December 3: "I am very glad I sent you a Down East blnefish. I did not suppose they ever came so far east as this to breed. That, with the Transparent Flonnder, will make two new eastern fish or fish not before recorded so far east. I hope when your new building is completed you may have money enough left, or appropriated anew, to have a good nice set of the best southern birds well put up. Many of them are very showy, such as the White Egrets, Ibis, Swallow-tailed Hawks, etc. You have all of them now but they are not a credit to a National Musenm."

July 9, 1882, Mr. Boardman writes: "I want you to name a hawk for me as I have liad one sent in that I cannot make ont. I have it mounted. It is a small hawk and not like any we find this way. I have none in my collection that I can make it agree with. It is about the size of the South American Hawk which I got in Florida winter before last - not quite as large and not dark on the back. Its back looks like that of Cooper's Hawk. Head very light streaked with dark; throat and whole under parts white; sides streaked with dark; feet and bill look more like a broad-winged; tail banded, but bands much narrower than those of the broad-winged or Cooper's." 



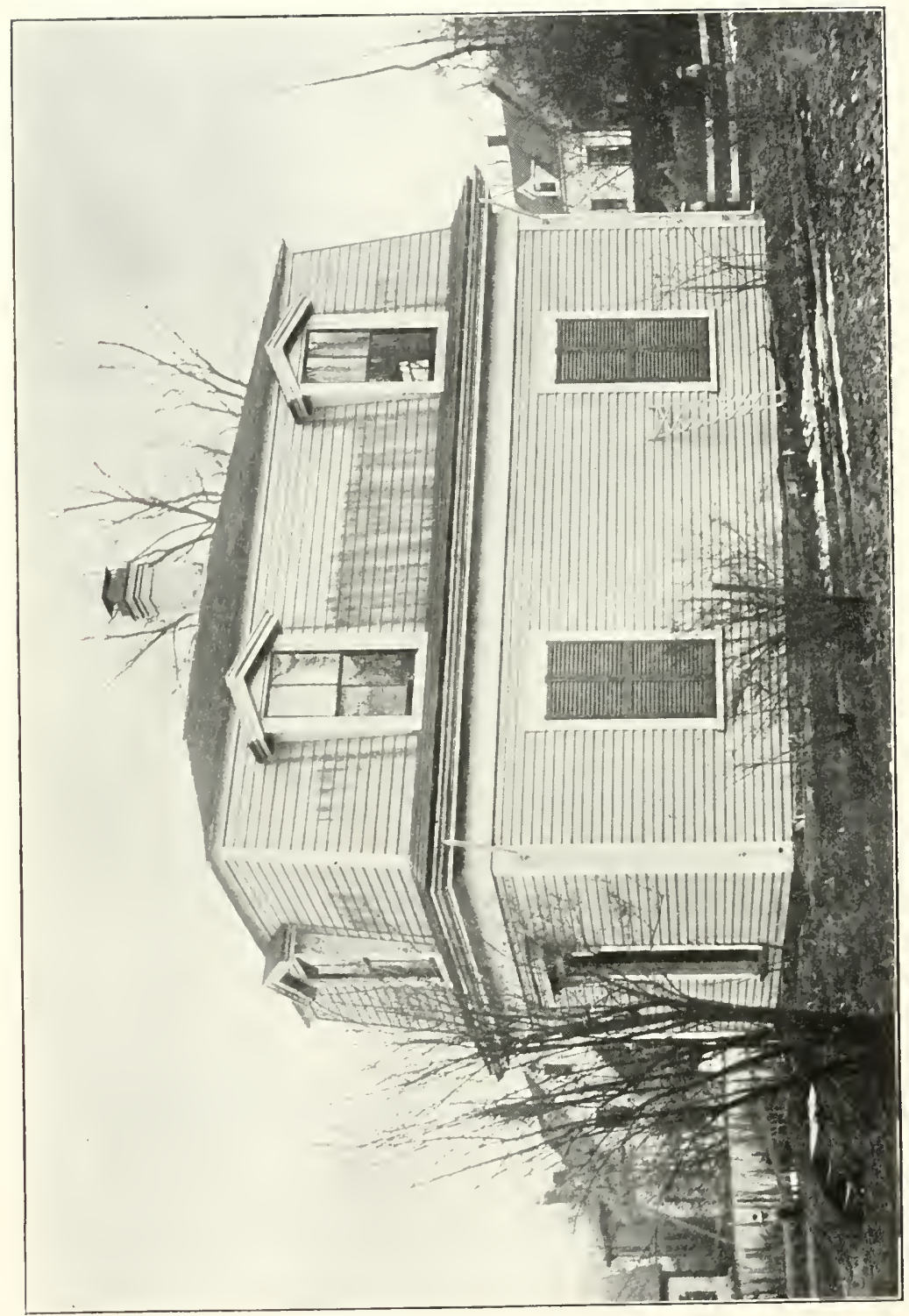

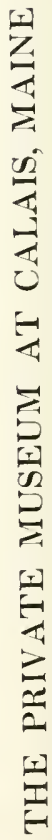


On August 30, 1883, he says: "We are getting our house at Calais in order to go honsekeeping again next season if all is well. We shall make our future home here and visit west or go south as we like. Mrs. B. wonld prefer to live in Minneapolis with the children, but I prefer the east. We hope to go south in the winter if Mrs. Boardman is strong enough for the trip."

In the winter of 1884 Mr. Boardman was in Florida and wrote from Jacksonville under date of February 16 : "I got a funny looking owl yesterday. The man says it is a Ground Owl; probably one of the Burrowing Owls, but it does not look the color of those I have seen. Have you the eggs of the Burrowing Owl from Florida? But there are so many cheats in such things you are never sure of what you have unless you get them yourself. I have seen three Everglade Kites shot near here of late - something new for this neighborhood." Writing from Calais under date of May 2, 1885, he says :

I starter a letter to you when I saw the report in the papers you was to leave Washington but before I sent it I saw the report corrected and I will tell you one of the items in it, was, "You will now have more leisure so you can take Mrs. Baind and lucy and come lown and see us." I want you to see our new place in Calais, and the way I have fixed my new museum. I put on another story; have a gallery around the secout story and have all the light from above. It never looked half so well and at Carais 1 have so many more visitors. 'The little plaster cast of trout makes quite a show as our people have never seen any such. I wish you could give the nuseum another, some salt water fish like a mackerel or any that you have duplieates of. I have not much that is fish, and as my museum is all the one down east, want it a good one, and while I am begging, should like one of those little koss Gull skins. 


\section{THE NATURALIST OF THE ST. CROIX}

All through the letters of these two friends are not only repeated expressions of the deepest friendship and closest personal interest, but on Mr. Boardman's part he is always looking out for ways to please his friend, becoming interested in what he is interested in, planning how lie can get things for the Smithsonian and always making inquiries about the scientific workers, what they are doing and what they are getting for the Institution. The personal allusions are always interesting. Writing to Prof. Baird from Boston, May 28, 1869, Mr. Boardman says: "The box of plants came to hand all right before I left and were in very good order. Mrs. Boardman sent for Dr. Todd to help unpack them and she divided them with lim. The ferns were first-rate and Mrs. Boardman wishes me to thank you for a box of the finest plants she ever received from Washington." Writing August 26, 1869, he says: "Thanks for Mrs. Baird's letter of yesterday; glad to hear you are home again all right and had a good time. I was thinking of you yesterday in the blow and thought Mrs. Baird better have a little extra insurance upon you if you were at Grand Manan. I note what you say about future work and think you had better all come up Monday. Then we will see what is best to be done." Prof. Baird had written to Mr. Boardman about a wash or preparation to apply to the hands and face for preventing mosquito bites and Mr. Boardman says it will no doubt be a great thing. "Get the Smithsonian," he writes, "to go into its manufacture. If you cannot get the large hall for the purpose get the capital and fit up that. It is time those political chaps were sent home. I can't see any good they do; most of them would be better employed at home making shoes, 
and can there be ont of the way of the great mosquito poison manufacturing company. I think I should like one thousand shares of the stock." "I have been out twice this week," he writes July 14, 1870, "but each time was driven lonile by showers. I however got, each time, some Ducks and Woodcock ; four Ducks one time. I think you had better let Woods Holl slide and come down bird shooting and shell-heap hunting." In one letter he writes that he is glad Mrs. Baird was pleased with the raspberries which are plenty and he would send them oftener if he could only get the boys to pick them.

In anotlier letter he writes: "I was expecting to go to Kendrick lake this afternoon to get some of those young Grebes, but Mrs. Boardman is to have President Harris and a lot of company to tea and she is afraid I shall not be back in time or may tear my pants and besides, she says Saturday is no time to have dead birds about and that I shall not go-so for the love of woman I shall have no chick Grebes this week." He writes about Prof. Baird having left Eastport when he was there in the late summer of 1869 , without having come up to Milltown to say good by, adding: "I was almost sure something awful would happen to you for it. Youmay think yourself very fortunate you were not all down to the botton of the ocean ; I feel thankful that old Neptune was so easy as to let you off with only a long swell. I hope you have been forgiven for the way you left. You must all be sure to come back to Georgie's wedding as we are to have a gay old time." In July, 1870 he writes: "I have hardly skinned a bird since I came from Florida - instead of mounting them I have taken to eating them. I think Woodcock and Snipe are best broiled, Duck 
roasted." In one letter written in July, Mr. Boardman says: "I see by the papers you have been having very warm weather and last Sunday read of a severe thunder shower at Gloucester. Georgie is like Lucy, very much afraid of thunder and she was having lots of sympathy for Lucy."

During the years of 1868 to 1872 Prof. Baird had been greatly interested in exanining the shell heaps along the Eastern Maine coast for Indian relics. At first $\mathrm{Mr}$. Boardman used to write him they were "a humbug," while on one occasion when Prof. Baird was planning to go up from Eastport and spend some time in digging, he said: "I don't believe the few old bones you will get are worth the trouble. I think we liad better go shooting and get something good to eat." Later, however, in his desire to aid Prof. Baird's researches, he gave much attention to these shell heaps, saying, in one letter, very frankly, "Since last summer they have more interest to 111e."

One day Dan, one of Mr. Boardman's workmen came from up river bringing one gouge, one chisel, two sinkers, a whetstone, a few other stones and some bones. He was gone four days, " which comes to $\$ 10.00$," writes Mr. Boardman, "but I do not know the value of such things in money." Then he writes that he has found "some queer stone things in a mound over at St. George." Again that he has "found ont by one of our pilots of a very big shell heap about three niles below the one we dug into at Simpson's last year and five times as large. I thought of going down but then concluded you had better come up (Prof. Baird was at Eastport) and make the new and great discoveries yourself. The 
pilot says he will lave a look at Grand Manan as he knows of a lieap on the point near Head Harbor light abont ten miles east of Eastport where your can easily go from Eastport any pleasant day." Prof. Bailey of St. John and Prof. 'T. Sterry Hunt of Montreal visited Mr. Boardman in August, 1869 and as President Harris of Bowdoin College was then at Mr. Boardman's, Dr. Todd took them ont to see the Oak Bay shell heap, as they had never seen one and Mr. Boardinan could not go.

Prof. Baird was also going to Grand Manan to visit the heaps at Lepreaux, Mr. Boardman writing: "I anl so far away I cannot always get down in season for good weatlier so you had better not depend upon me as Cheney will show you all the places." Again he writes: "The day Dr. Todd was down to the heaps with President Harris they found a large rib bone of some animal very much larger than the largest ox or moose. I will bring it down Monday and perhaps you can tell what creature formerly used it. Dr. Todd thinks the bay sliell heap would pay to dig all up - we will see about that, however, when we cannot find any new ones to dig that are more interesting." Finally, regarding these shell heaps Mr. Boardman writes :

I weut to St. Andrews last week by land. I ealled to see Mrs. Simpson. Mr. Taylor was with me and we went down to see the old shell heap as I had heard nothing from it since the great October tide and gale. It was badly washed away. I think nearly ten feet must have been earried away since the first time we saw it. It is all away now up to a little above the fence. There was so mueh drift stuff all about that Mr. Simpson could find nothing of any account. He did, however, find one bone with a hole in the middle, sharp at each end and about five inches long, probably used for a needle, and also one or two stones not 
amounting to much. I will try to go down when I have time and give the beach a good overhanling. I am glad you came when you did to see the heaps for it will not be very long before most of them will be washed away. The gales last fall probably destroyed dozens of them about the coast. But if you will go to Florida with me next wintel we will go shell heap digging all winter as there are plenty of them there.

Mr. Boardman's letters are full of interesting personal allusions showing his interest in people. Writing January 3,1869 , he says: "I have often thought of your sick friend at Beverly, I think lis name was Swan. Did you ever hear from him after his arrival in Europe?" October 25 of the same year: "Write me if Ridgway is with you and if he found much that was new. Give him my kind respects." November 29, writing of Dr. Brewer he says: "I have no doubt Dr. Brewer and family will find Washington much more pleasant when Congress is in session and know they will liave a fine time. The doctor will be in clover when he gets at the eggs. I always like to look them over but I think I enjoy that chap's steamed oysters, down on the avenue, fully as much - better still your splendid library." After returning from Boston in November, 1872, where he went to witness the ruins of the great fire he writes: "You have heard by the papers all the particulars. Dr. Brewer looks as smiling as though he had found some new egg. Their stock was all burned, not a thing was got out. Many of our friends lost all." Writing from Jacksonville, April 12, 1875, he says : “I have given Dr. Henry Foster, owner of the great sanitorium at Clifton Springs, a letter of introduction to you. He owns a splendid establishment up at Lake Jessup, twenty-five miles above Enterprise. He is one of the best men I ever met in 
Florida and I want you to know him. If you ever get time to cone to Florida he wants you to risit him : lie is away in the woods where people cannot find hin. He built the little steam yacht Clifton, which I was in several winters. He expects to be in Washington next Sunday. Mrs. Foster is a sister to Mr. Edwards, the butterfly n11an and a very fine lady." November 24, 1878: "When you wrote last you was about sending a man to Georges to collect sea birds and other natural history specimens. What did he get that was new or interesting ?" February 6, 1879: "When I left Washington last April Prof. Glover was quite ill. I have never heard from him since. Did he recover?"'

"I have not written you," says Mr. Boardman in a letter dated February 2, 1880, "since I heard of the death of Prof. Milner. The last you wrote me about him was in the spring, that it was thought his trouble was not with his lungs. I asked about him in some letters but as you did not mention him I supposed he had recovered and was with you at his work. I was very sorry to read of his death. He was a very nice fellow. And then so soon to read of the death of our dear old friend Dr. Brewer. It was a great shock to me. I had not heard of his being ill and having letters from hinn every little while did not realize he might be sick. I shall miss him very much. He was such a home body, too. I hardly know how Mrs. Brewer and Lncy will get along without him. But this must be the way very soon with all of us old fellows - our time will soon be up."

Writing in reference to the Fisheries Exhibition in London in 1880, he says under date of April 5 of that year: "I expect you were very busy getting your 


\section{9. 'THE NA'TURALIS'T OF 'THE S'T. CROIX}

exlibition specimens away and expect before this you have heard of the safe arrival of Prof Goode. I feel quite an interest in how the show will take on the other side. If we do not get a good account on this side from the newspapers you must write me about it, or, better still, come down and tell us all about it. It is now our turn to have the fish commission down this way. Provincetown, Gloucester and Woods Holl must be about worked out and I know there must be some new fish in Eastport waters that require looking after. * * * Do you ever hear anything from Henry E. Dresser? Did he ever finish his birds of Europe? He sent me thirty-six n111mbers and I have lately written him but as yet get no answer. I should be pleased to hear of his prosperity and that the book was finished and made to pay. You wrote me last year that there was a prospect of the Water Birds (Baird, Brewer and Ridgway) being publislied by the Cambridge people; I hope they may do so. Is there anything new? I have added another bird to my list taken at Grand Manan - a Fulmar Petrel. I expect they are often about the fishing grounds only not looked after and hence not discovered.'

"I called when in New York," Mr. Boardman says in a letter written at Boston under date of May 29, 1882, "to see Dr. Holden at the American Museum. He said they wanted a good taxidermist. I told him about Mr. Webster of Rochester; that I had recommended him to you and that I thought he was partially engaged to you. I hope you may have him in Washington and from what I saw of his work at the meeting of taxidermists at Boston last winter, think he is just the artist for the National Museum, who with Hornaday, Lucas and Marshall would 
make a tean that woukd be hard to beat by any of the European museums."

Writing at Milltown, July 23, 1882, he says: "I received your letter and think I should not have answered it so soon only to ask about Nelson who, you say, has gone away to Colorado, sick. When you write tell me what the natter is with him. I wish lie lad come this way for I think our summer clinuate very hard to beat. He wanted me to send hin a few skins of our eastern birds from my duplicates. I sent him many and wrote him but did not receive an answer." Again on December 29, of the same year, writing from Minneapolis, he says: "I have not been able to hear from Mr. Nelson. How is he? Have you heard anything from Turuer? Let me hear." In 1853 , on March 6, he writes: "Have you anything new from Mr. Nelson, if so let me know. I hope to hear he is better."

"I received a letter a few days ago," Mr. Boardman writes on September 8, 1885, "from a Mr. Wright which I enclose. I liave nearly forgotten about the ring as it was fifteen years ago. It would be just like me to get the ring (I learned that trick from you) for the Smithsonian. If you have any book such as he describes, please have it sent him or send some other book. The ring, I think, is in the large room at the Smithsonian. It was dug from an Indian mound." And so the happy record goes on until the long and intimate friendship, uninterrupted for a period of nearly a quarter of a century, contes to an end. 


\title{
194 THE NATURALIST OF THE ST. CROIX
}

\author{
Letters from Mr. Boardman to Prof. Baird
}

Milltown, Maine, Jan. 4, 1865.

\section{DEAR IBAIRI):}

I received your last letter and should be glad if I could give you any information that would be new in the northern distribution of many common birds. I have long been a close olsserver of the habits and for some time have been a collector of birds, and in my journeyings from Massachusetts to Western Maine, to this neigliborhood, North Eastern Maine and New Brunswick there appears to be a different fauna. We do aceidentally find many more southern birds but only as stragglers and in this neighborhood have found two hundred and forty species, and I think this is about the southern locality for the breeding in abundance of many northern birds, aud too far north and east for the breeding grounds of many most common Massichusetts and Western Maine birds. Among the birds that breed common with us and are best known are the little blue snow Bird, one of our most common summer birds. 'The White 'Lhroat Sparrow very common, Yellow Iiump very common, Black ['oll Warbler, Hermit 'J'hrush, Canada Jay, Pine Finch, both Red and White Cross Bills, Spruce Partridge, Winter Wren, Black Back Three-toed Woodpeeker, Yellowbellied Woodpecker, Yellow Red Poll very common, as are the most of the above all summer. 'The Duck IIawk, Pigeon IIawk and Goshawk are not at all uncommon. I found the Phalarope breeding in two places last season; Blne Wing 'Teal find breeding every year. 'The Golden Eye and Sheldrake (Mergus Anericanns) breed very common, both in trees and are common with us winter and summer, as does the Hooded Merganser (?) breed in trees but is rare in winter. The Eider Duck breeds common about the Islands and once found the King Eider at the Islands first of June, probably breediug. 'The Gannet and Cormorant, a few breed; IIerring Gull are abundant all summer and also breed about the fresh water lakes. The great Black Back Gull also breed, but are getting rare. I also find through the forest in summer very many Warblers and think nany of them breed in abont this latitude but our forests are so extensive I seldom find the nest. I forgot to say the Razor Bill, Puflin and Sea Pigeon, 
Mur (?) were with us all sumner, but not very abundant. We also often find stragglers from the north in summer, but are so uncommon are hardly worth mentioning, such as llawk Owl, Snowy Owl, lichardson's owl, ele. 'The most of the hireds I have mentioned you will rarely fiud about Massachusetts or Western Maine in summer and many of their common birds we never see, and others very rarely. 'The 'lowhee Bunting and Brown 'Thrush we never see. 'The Mealow Lark only one specimen, Blue Bird rare, Cooper llawk and Mottled Owt very rare, Yellow bill Cnckoo very rare, IIouse Wren also rare. Inve never found the Prairie Warbler, Worm Eating Warbler or l'ine Warbler, but I believe I wrote you I found a nice male specineu of I'rothonotary Wabler two falls ago. There has been considerable written about the Clifl Swallow migrating south. I came from Massaehusetts to this part of the country in the year 1828; the Clill Swallow was then very abundant, huilding the whole length the eaves of barns, as mueh we see them now, which was not the ease in llassachusetts.

I have written in considerable hury withont any method or aramgement and if there is any idea new to you I shall be well repaid. I have for a long time been surprised there should be in so short a distance as about one humbed or two hundreal miles so great a change in the breeding places of many hardy and early birds as the Blue Bird and others of Massachusetts and then that we should have so many that do not breed with them. 1 also find in Southern Nova Scotia, Massachusetts birds much more common. Ilaving been so busy of late, I have not had time to attend to our favorite pursuit, but hope to be looking up something as soon as 1 go up to the logging camp.

Wishing you the compliments of the season, I am

Iour's very truly,

GEO. A. BOARIMAN.

MLLTOWN, 6 Sept., 1865.

DEAR BAIRD:

I have but just received your letter of the 4th, eould not get it last night; Charley waited for the Eastport unil to open but somehow it did not get into the box. 
I hope before this you have my letter written Monday. 'The stage man I have not seen since Monday. I intended going to Calais today but it is so rainy 1 may not go down. Let me know which way you prefer going and I will malse the best trade I cun. The air line man only asked $\$ 30$, the Machias man $\$ 35$ but said he would do it as low as any one. The air line would be one day shortest, and a very nice, romantic ride through the woods, of 45 miles each day. 'The other way three days of 40 miles each day, and the former air line way would see, I think, plenty of birds to shoot, and I think the air line you would like best, but if you prefer to go by way of Machias, I think I can get you taken along at about the same price, $\$ 30$, aud might possibly get the air line man to say $\$ 25$; if the rain holds up will go down to see. My colk is better but far from well.

My brother and nephew I told you about up the river got down last night; shot fifteen ducks, one bear, some partridges and other game. I wish we had gone that cruise; they took an Indian and a canoe, went up, Chepetnicook river and back, say the river was full of Ducks, Mergansers and Divers of one kind and another all the way.

Charles goes baek to Brunswick tomorrow. I think he will get this letter to you before the mail.

I have just left off writing. A man has bronght me a Goshawl; it flew into his barn after the hens and he killed it with a chl). 'They are our most destruetive Hawk, and will take hens from the doors of ayy conntry farm house. It is in young plumage, the eyes yellow; the old birds have red eyes. 'This makes quite a variety of IIawks for' a few days - Red Shouldered, Broad Wiuged, Cooper and Goshawk.

I notice what you say about your Paeific letter's, should be much pleased to read some of them. Why not send up by Capt. Spring all you care to have me read. I will have them liept safe until you come up, or leturn them next day, and should like very much to read some of the letters from your Hudson Bay Co. corlespondent you was telling me about. There is no reading I like so well. I should like to have you look over Prof. Hinds' bird list for birds you think were never found in the province, or lend me the list as I want to write the man to know how he came 
to beat me in finding rare things, and perhaps I can get some of his speemens. Charley has just rome from Mr. Spanlding's who says he will take you (lits ronte is by way of Machias) for thirty dollars. It is so danp I have not been out much to-day. I am sorry you have to go so soon. I expected to have a good cruise somewhere but it doesn't look much hike it now. You must come another year. Let me know the day you come up.

Yours truly,

BOARDMAN.

JaCksonville, Florida, February 1, 1868.

DEAR Baird:

I have been thinking of writing you for a day or two, but there are so many new things to look at I have not thought of hardly writing home.

After I left your house we had a good passage to Richmond where I spent one day, then went to Wilmington, made a short visit. Next day went to Charleston, where I spent nearly a week, arrived here day before yesterday. The weather when in Charleston was very fine. I had a nice visit. I called to see Dr. Backman; he was very glad to meet me, full of talk about old collecting times. He is seventy-eight years old, but quite active mentally. He has lost the use of one of his arms. His library and valuables were taken for safe keeping to Columbia, to his son's house, but when Sherman's men burned the place all his valuables were burned, which if they had been left at Charleston would have been safe; all his specimens were destroyed. The soldiers nearly killed him because he would not tell them where the plate of the officer with whom he boarded was buried. IIe admits he was a little savey to them. He was glad to hear from you and sents his regards to you and Mr. Brewer. He had very many questions to ask about ornithology as he had hardly looked at a book or bird for eight years. Since I have arrived here we have had a cold norther. I have not had my gun out; the place is so full I can hardly get a room, and if I do not do better shall go to St. Angustine to-morlow, and try to get a clance down the coast. 'There are no vessels here and the collector, Mr. Moody, says he does not think there are any vessels below Fernandiua belonging to 


\section{THE NATURALIST OF THE ST. CROIX}

the service, but St. Augustine is the better place to get down the coast.

I see many birds new to me such as Cardinals, small Crows, Buzzards, diflerent kinds of Gulls, Terns. Blue Jays are quite common, but have not seen one Florida Jay. I see many of our summer birds, Robins, Grackles, Red Poll Warblers, Sparrows, ete., etc. I saw in Carolina very large flocks of Doves, Meadow Larks and Blackbirds. I have agreed for some Pouched Rats if the boys can get them, also the Land 'Turtle. The negroes eat the latter. I have seen ice two mornings since I have been here, the first of the season. The orange trees are full, and some few in blossom. I find the express of a small box of oranges to New York will cost three dollars. Adams \& Co. does not eome here.

With many thanks for your kind attention when I was in Wrashington, hoping you, Mrs. Baird and Lucy are all well, I am Very truly yours,

Geo. A. BoARdman.

\section{DEAR BAIRD:}

$$
\text { JaCksonvilue, } 13 \text { March, } 1868 .
$$

Since I wrote you at G. C. Springs I have mate up) a box of about fifty hirds and sent hy express. I could not get them along with my baggage as I shall return by land. 'There are three Salamander skins, by the boys, not done very nicely. I sent another box in a trunk to Boston and can send back by Adams \& Co. 'They were collected at St. Augustine. My collection made here I can't find, they were left with a friend until my return; he has gone up river, may get them before I leave. I hope you may find some you may want. I had no arsenic to prepare large biris, and all the larger birds I did not skin. I did not shoot anytling very rare; there were some good White Herons and a few IIawls, nothing very rare. I slall probably leave for Savanuah 'Tuesday next, from there go to Augusta, Aiken, and so along to Norfolk, and he in Baltimore the last of the month. Very few birds have begun to breed except the larger, as Fish Ilawks, Eagles, etc., ete.

I like this elimate very mueh; think I shall try to spend my winters here. I luave the promise of some collectors down at Indian river, to get and send you some eggs; hope they may do so. 
Another winter I hope to come prepared to go to the head of the river and eamp out and have a regular hunt. I have been at most every place on the St. Johns river - enjoyed niyself very nicely. Wish you could spend a month or two visiting this very interesting part of Uncle Sam's farm. Hoping Mrs. Baird is all well long before this and with kind regards to her and Luey,

I am very truly yours,

Geo. A. Boardman.

I'. S. Please excuse the pencil letter as I have no ink. I could give Prof. Henry the standing of the thermometer at Greencove Spriugs every day since the 1st of January if wanted. Ilave not had a rainy day for three weeks, most beautiful weather, thermometer often up to $80^{\circ}$ in the shade at noon. It was $84^{\circ}$ at five o'elock this afternoon.

My Dear Bairo:

Mrlutown, 25 May, 1868.

I received your letter of the 20th May. I have no one I care about in the egg collection and anything I get you can have. The Goshawk's egg you can have and I will try to get the nest; it was built in a branch of a birch about thirty feet up, quite a large flat nest, outside of sticks, inside fine stuff and moss. I went near the same place for another but found it only a Broad-wing. I got three good eggs. It was a very rainy day and took me about all day - got well soaked. I also went up to the lake but it was so rainy it did not pay - glad to get home. It has rained all the time for two weeks; if fine I shall try to go up again this week. I know where several Whistlers, Mergansers, Wood Ducks, etc., breed and I want to get them for you. I went to the nests when up but it rained so hard I could not get any one to go up; they are very high and the trees are old and rotten. 'The Piue Fineh eggs and nest you ean have and, as I said before, any eggs and nests I get, also the Canada Jay's nest and eggs you can have until you get more and then you can return them. Brewer wants the nest and eggs to figure or compare all three - Goshawk, Pine Finch and Canada Jay - as he is at work for the egg book, suppose it will be right to send to him for a time with instructions to send to you. The Jay`s nest is a very odd affair. I shall have to go to New 
York the first of June or about that time; will send them to you or leave them with him as you say. I will also send what Newton says is Pine Grosbeak; they were sent to me for that by young Dresser, brother to Henry E. of London. I wrote H. E. about the Steller Dnck egg, told him to send to you. I expected to do a good thing egging this Spring but the weatler has been so bad I could not go in a eanoe without getting wet through. Hope this week will be better but it is now raining and I am writing very fast for the mail. How about the Pied Juek? What has become of the bird? it used to be common; ean it be possible it will beeome extinct? A clumsy bird like Great Auk or Dodo might get run out but a good diver and flyer like this duek should take care of itself. I did not know it was so rare; supposed your northern folks would find it breeding; I think they must have goue to some other parts; you must look them up by your collectors; they may be down to Newfoundland.

I wish you were here to go up to the lakes fishing this week. We would have a good time. I am sorry to have to go west so soon as I prefer to be here this season.

Kind regards to Mrs. Baird and Lucy.

As ever, yours,

Geo. A. BoARuman.

My Dear Professor:

Milltown, August 22, 1868.

I have just received your letter of Angust 20tl, sorry you are so long getting away. Was looking for you to-day. Come as soon as you can, Wednestay or Friday if possible. I think it would do Mrs. Baird and Lucy good to take a steamboat trip with you. Dou't talk about must be back the ensuing 'Thursclay or Saturdity, but say, must be baek the ensuing 'J'hursday or Saturday, if God (and Geo. A. Boardman) are willing. I notice what you say about digging old clams. 'There is a large lot of old heaps near St. Andrews. I told Dr. Adlams abont digging into them, as he has been for two weeks attending court there. I do not know what has been found. There may be more of such shell heaps about the islands. I think if you dig them all over you will have to stay more than a week. There is also plenty of Waders about and you can dig the old elams and I will shoot the birds. I think 
I should have a better time shooting than digging. I don't have much of a faney for diggring, but ean get some one to do the rongh. We will see about this when you got here. I will indure if there are any other heaps. My friend, Mr. Osborn, may know of others. 'The st. Andrews people have hauled lots of this heap away for manure; they may have found some good things. If so we possibly can get them.

I received a letter a day or two ago from Dr. Brewer saying among other things, that another book (not by Samuels) was possibly to come out, ealled Birds of New England, or a new edition of Nuttall. I should be pleased to see it.

There is a Mr. Darling, a clergyman, spending the summer here from Kenuebunk, whom I told I expected, some, a Mr. Swan from his place; says he knows him very well, and that he is one of the best men in New England.

Please excuse the haste with which I have written and remember us to Mrs. Baird and Lucy. Hoping to see you very soon I am

Very truly yours,

G. A. Boardian.

P. S. Fred and Albert were very sorry you could not be here before their return to college. Albert left yesterday; Fred leaves next Friday.

DEAR BAIRD:

Milltown, 29 October, 1868.

I received your two letters and the money for Dan's bill.

Glad to hear you had returned to Washington and got settled into your work again. I expect you must have found some new things among Dall's collection. If anything very rare let me know.

I have just returned from Boston where all the family have been on a visit to see Charley married. He went away south for a short cruise and I do not know but he went as far as Washington, if so he would go to the Smithsonian and you would be likely to see him. We expect him home'Tuesday night. Georgie returned last night by way of Bangor, after a cold, windy ride. We are having very cold weather for the season, have had two hard snow 


\section{THE, NATURALIST OF THE ST. CROIX}

storms; this morning the thermometer stood $18^{\circ}$ above. Ice strong enongh for boys to skate, something very rare for October.

I have not had time to go shooting this fall, but hope if we have fine weather, to go away a few days. 'The winter birds have got along, and everything looks like winter; our lumbering operitions will soon close.

I am lieeping a lookout for anything 1 can hear about the shell heaps. There have been several men here selling horses from Prince Edward Island. They say oysters are more abundant than clams and they think there are plenty of old heaps but don't know how ancient any of them may be. I have heard more about the stone profile found in the old mound at St. George, but am afraid we cannot get it as it has been sent to St. John; but next summer perhaps you may talk them ont of it, at any rate you can get the loan of it, or perhaps exchange. I lad a very aneient Indian anchor made of wood, hooked up out of the lake. I do not know as it would hardly pay to send, but is quite an oddity and looks very old.

When I was home, I tried hard to find some butter that would answer you, and have it sent from up country but it is very poor and costs forty cents; I have put it in the shop, and am expecting more. I shall not send anything Mrs. B. does not approve. I made a bargain with our butter maker for all he had or conld make in the spring at thirty cents on the English side, but some butter speculators eame along and offered him forty cents and I lost it or the most of it. I will keep a sharp lookout for a good firkin or two. 'The duty, twelve cents in gold, is very much against the English side butter.

If you have a set to spare of antelope horus, also a bow and arrows such as the Western Indians use to shoot buffalo, I should like them. I want to slow the latter to our Indians, also a pair of snow shoes that turn up at the front. I think if our Indians ancl moose hunters would make them like the lot I saw at the Institution they would be much better than such as are used this way.

With kind regards to Mrs. Baird and Lucy, believe me

Yours as ever,

Geo. A. Bonruman. 
Mrlitown, 24 June, 1869.

\section{My Dear Plofessor:}

I received your letter of the 20th to-day, glad to hear you are all well. Mrs. Boardman is some better part of the time. Most of the trouble is with her head. I keep her out riding all I can. IIave just been out to the cemetery; shot a new kind of Pewee. I will let you tell me the name when you get here. If the short legged Pewee ever came here should eall it that bird, as it is not large enongh for Olive sided. 'There were two but I could not find the nest and had to be contented with the bird.

Your friend, Senator Edmunds from Vermont, has been down on his salmon tishing cruise, went home this morning perfectly happy. I could not leave and Fred went up to the lakes with him. 'They were gone one week; had a very nice time; eanght more of those little salmon than was necessary for sport. Caught two hundred; some weighed four pounds, averaged two pounds. Fred told the Senator about the Indian things in the banks and he lug ont a nice arrow head and part of a spear. I think the latter, i. e., Indian things, were on your peruit, and the Senator had no right to anything but the fish. I believe I told you I got one of the lake salmon last fall that weighed over ten pounds. I have it nicely mounted.

I am glad you are getting so many nice things from the other side; they are very good to compare, and I am of the opinion that uany of the European birds that we have given a different name are not much diflerent from American.

I notice what you say about making Eastport your headquarters. 'The new hotel is not yet opened, don't know when it will be, but probably pretty soon. 'They have been so fardy, not knowing who will keep the house, they have no boarders engaged. 'The air is very fine in summer at Eastport, but the company is ten times better at Milltown, and much better diggings of Indian remains. I lave been looking for a good boarling place here, but camnot find anything that will do. It is almost impossible to get good help, but thought we could take good care of you, and had Mrs. Boardman been as well as usual would not let you lave gone to any other place, and at any rate, must be with us part of the time, aud will have plenty of chance to look up a 


\section{THE NATURALIS'T OF THE S'T. CROIX}

place and I can go to St. Antrews or Eastport if I can do anything. St. Andrews is a very quiet, pleasant place but don't like the company. We must try to go to Grand Manan and other places and hope Mrs. Boardman will be well enough and all the ladies go over. With much love to all.

rours truly,

Geo. A. Boardian.

Militown, 4 Aug., 1870.

DEAR BAIRD :

I have but just received your letter, very glad you are having such a nice time boating and fishing. I see by the papers the weather has been very warm west. I am glad you found a cool place. We have had a few warm days, but to-day is almost cool enough for a fire. Mirs. Boardman is very poorly, takes most of my time to see to her. I keep her out riding all I can, the doctor wants her to be kept free from care and excitement. She is very nervous; last week, hardly left her room, but this week is better. I notice what you say about the duck. I don't know about the female Red Head, the bird has always been very rare with us. I don't know as I ever saw a female to know it, the male, I have got one or two of the gunners but a long time ago; the size was so small I did not think of its being the female of the Ring Neck, as the male is quite a good sized duck, and this not larger than a Ruddy or Teal. I have just been looking at the description of the female of the Ruddy, and it is so short I eannot make much out of it. I have also looked at Audubon's description and plate, which does not look anything like this bird, only the spot on the wing is the same. Audubon says its breast is white. This bird has a very dark ruddy, or chestnut brown breast, and belly about the same as the Ruddy. Audubon's description does not come near it, but he may not have seen it in breeding plumage if it changes, and he says the male has large tufts in breeding time. Should it be the ling Neck, it would be something new to lave it breeding in Maine. Frank Todd was up at the same place shooting, and I told him to keep a sharp lookout for this duck, and he found another brood and old one. The old one he missed but shot one chick which was the same, so there wcre two broods. 
Is the Ring Neck a duck that breeds very far north? Have you the eggs? I may go to Boston soon and will take the old duck and chick, or if I do not go, will send to the care of Dr. Brewer. I shall try to go up again and see if I cannot find the old male or at any rate get some good ducks to eat. Love to all the folks.

\section{Dear Professor:}

Geo. A. BoARDMAN.

Milltown, Nov. 21, 1870.

I received your letter a few days since. I wrote you in $\mathrm{my}$ last about finding another black-red Squirrel; since I have had a very pretty snow white one with pink eyes, so if you have a black one, I don't believe you have so pretty a white one, and I hear there are more at the same place and hope to get another for you.

Since I wrote I received a letter from the moose man who says he will get the skeletons this winter but says I must give him more than I offered; says the horns sell for five to ten dollars. I tell him if he gets good large ones I won't miud a few dollars; we may have to give him $\$ 10$ to $\$ 15$ for two, but I want you to see them before I pay, as he might lose some of the small bones.

I suppose the little duck could be no other than Felix Collaus but it was so small and so different from Audubon's figure I was not certain; there were some at the shooting party at Frinceton looking just like Andubon's figure, with white belly but all larger than the one I took in the summer. I must try another spring to look up the streams to see what ducks breed in New England that we have never found; the Barlow I think does, and before you finish up your book I want to have some new things in it. You must note the red Phalarope as breeding with us. Hope Maynard may find some good things down on the Keys. I did not hear before anything of Stimpson's expedition. He might find you a skeleton of the Sea Cow along the coast. I think I shall try to go down Indian river this winter after I get settled; think I shall send my horse and carriage down for Mrs. Boardman to ride about the woods - she and Willie I think will go down with me. We shall try to go away about Christmas. Wish you could spend a few weeks to go down and see the country, Alligators, etc., etc. We are having nice warm weather for the season, mills all going 


\section{THE NATURALIST OF THE ST. CROIX}

- lots winter birds about, such as Pine Grosbealis, some pretty Chatterers down in Mr. Todd's garden; he doesn't want me to shoot the Wax Wings. Love to all your folks.

As ever yours,

Geo. A. Boardman.

My Dear Professor:

Milltown, 19 January, 1875.

I received your letter a few days since; sol'y the postal car got burned. Don't think of much news to write, very cold weather is no news for us. We have had a very long cold suap, thermometer sometimes 25 below zero and hardly get up to zero all day, wind blowing a gale most all the time.

This would be splendid weather for some of you people writing up water birds for the other volnmes. Such winters as this should bring down lots of new Aretic birds, such as Gulls, Divers, etc., ete., and a splendid place would be to go to the Wolves Island, up in the Bay of Fundy, out on some of the rocks; it would be a very bad place for boats, but a fellow might swim after the birds, if he shot any very rare ones, and he could skin them after he got home as they would not spoil, this weatler, in two days. Joking aside, I believe for some good naturalist to go to such a place as the Wolves, and stop with a Mr. Paul, who lives there, would get more rare things than he would at most any other place. Many winter birds come no further than this. No one shoots this time of year, or ouly to shoot a duck and many good birds are overlooked; no collectors go in winter. I was ten years trying to teach Cheney, but had to give it up. Audubou, Wilson, Nuttall, etc., ete., all went south iu winter. A Mr. Stewart was over to the Wolves and told me he saw more than five hundred Harlequin ducks in one cove. A good chance for any young collector that wishes to make a martyr of himself and freeze to death here is a good chance. I think before long I shall go south again, probably to Florida; if there are auy particular birds $\mathrm{Mr}$. Ridgway wants me to look after, let me know. I shall probably go south without much delay and stop on my return along by the way, as after I start want to get as soon as possible into warm weather.

With kind regards to all the folks, I am

Yours very truly,

Geo. A. Boardian. 
MILltown, N. B., Mareh 15, 1880 .

\section{My Dear Professor:}

I have not written you for some time for the good reason I had nothing very new to communicate. I have been on the lookout for anything worth sending you in the way of birds. Some good sea birds have been sent me but were not fit to send in the tlesh so far. I have just had sent in a pair, male and female Barrows, just killed and thought I would send them to you and only sorry I liave not a good Labrador Hawk or some other good birds. Have only heard of one Gyrfaleon being shot this winter and that was in Massachusetts. I believe I wrote you I got a Stone Chat shot at Indian Island.

So much for birds, now about fish. I suppose you are very busy getting things ready for Europe. I was glad to see Prof. Goode was to go away to represent you and have no doubt you will have a very fine show; almost wish I was going myself. I see l'rof. Bean is going up to Alaska. All your fish folks will be away exeept Prof. Gill and he is quite a team by himself. IIope you will have good success with the shad; our river used to be a good shad river until the dam was put across at the tide mills and none have goue up since; they were very abuudant at St. Johu last year; they were retailed at ten eeuts. 'The P'orgies have left us entirely, been none for years.

My lame knee is much better, can now walk about on two canes and hope by spring to go alone again. If I get so as to walk hope to go out to see the boys at Minneapolis in May as we lost our visit in the fall. We have had a nice winter, good sleighing since November. I expect your new Museum is done; must try to go and see it as soon as you get it in order.

Mrs. B. joins me in much love to you and Mrs. B. and Luey. Sincerely yours,

G. A. BoARDMan.

P. S. 'The birds will want to be looked after very soon by Mr. Marshall.

Mlltown, St. Stephen, N. B., Aug. 1, 1880.

My Dear Professor:

I have not, I believe, written you since my return from out west; one reason I had not much news to write about, another 
was I knew you must be very busy getting realy to go to Newport and the folks away with so many things to the great fair in Europe. We arrived home four weeks ago; found everything in good order about our premises. Was sorry not to have been able to remain west until fall and liad some fall shooting. I was surprised to see so many speeies of ducks breeding in the vicinity of Mlinneapolis; I saw floeks of male Ruddy Ducks, Blue-wing Shovelers, Gadwalls, Blue-wing 'Teal, as well as Wood duels, Mallard, Hooded Mergansers, ete.; saw but few females as they were away breeding; saw some Franklin Rosy Gulls shot, real beauties. I believe I wrote you of seeing Blue Ileron, Crested Cormorants and Blackbirds breeding all on the same trees at Lake Minnetonka, also Swallow-tail Hawk near the same place, but the eggs were hatched. On the way home at Chicago we were told of the marriage of $\mathrm{Mr}$. Dall but did not hear who was the lady. I have been away a week with Mr. Hersey up St. John river to the Grand Falls. Ifad a nice trip. John 'Taylor' and Georgie are with us and we expeet Charles' wife and children next 'Thurstay.

We are having nice cool weather and hope you and Mrs. Baird will be able to come down to make us a visit. I know Newport to be a nice place but for eool, nice weather Eastport and bay of Fundy are hard to beat this time of year.

All join in much love to you, Mrs. B., Lucy and all the friends.

Sineerely yours,

Geo. A. Bonlidian.

My DeAR Professor:

Milltown, N. B., 19 Sept., ISs0.

I received the paper Republic you sent me. A very good picture of your house and a very good account of your dear self, written by some fellow that knew you pretty well, but some points he did not get in. IIe should speak of your love of nice kid gloves, and how good you always feel when you get on that swallow tail coat, ete.

I also reeeived your letter about a month ago; hope you may all have a pleasant time in Newport this season. I know Mrs. Baird and Luey must enjoy the place in summer and would be pleasant to be with Capt. Churehill's folks. We have had a fine cool summer, Charles' wife aud children, Georgie aud Mr. 'Taylor have 
been with us most of the summer, but have now gone home. We wiss them very much.

My lame leg is gretting stronger all the time lut get tired when out womleore shonting very easily.

llave not fomm anything very new in the waty of birds or fish; was up to St. John last month and fomm a birl stufled with an Aroset, just mounted; said there hal heen three this season, and shot at Inaen. I wrote to the shonter and he says he gets then every year on two. I had one sent me some years ago from Maces Bay and lave two in my collection. Dr. Brewer thought very strange they should be found in this neighborhoot and never me recorted as being taken in New Englaud.

Mr. Wilson thought he had a new flounder and wanted it sent you. I knew it was a common fish to you, but very rare here. Called by some Spotter 'lurbot, a very thin, trinsparent, spotted tlounder, Lophopsetta maculata. Ifow far north are they common?

I have written several letters to the fishemen to be on the lookont for a small size basking shark if one can be fomml, lut the fishermen say they uever have seen a very small one.

I expect the new hibling in Washingtom is abont finisher Hope I may not have any mishap to keep me from going sonth this fall so as to see what you have got now added to the sinithsouian.

I hope the Fish Commissioner may get down enst next year. You wonld find Prince Edward Island quite interesting to look after new fish. 'The water is very much warmer than the Bay of Funly. When there year brome last the bathing was very comfortable, but never in or about liay of Fundy waters.

Mrs. B. joins in much love to yourself, Hrs. Baind, luey and all the friends.

sincerely yours,

GEO. A. BOARIMAN.

I'AlatKA, Florida, s .January, 1882.

My DeAR Professor:

I received your letter some days since, glad to hear you are all so nicely.

Charles has been very busy and I do not think he has taken interest enough in looking after the diggings of his railroat. There was one momml, he says, there were a good many long stone 


\section{THE NATURALIST OF THE ST. CROIX}

spear heads and knires, some I have secn that are very pretty, that I am in hopes to get. 'The young men in the road employ have them and I am mounting up some pretty birds that I may exchange for the stone things. 'They were found last spring near l'alatka and most of them have been taken north. I will now be on the lookont for anything they may find. 'The diggers are now ten miles sonth of Ocala; no track laid within fifteen miles of them, but hope to go down before very long. Have seen no new ol very rare birds, ouly yesterday saw one of those white-tail, or black shouldered Kites brought in.

'There is one very good taxidermist here; he puts up Waders very life-like, the best I have seen anywhere. Sands is also at work and is doing very well; has a nice place near town but cannot do up the Wader's so artistic as the man IIoyt, not the Hoyt you saw when you was in Jacksonville, II. II. Iloyt from Stamford, Conn. Ile can also draw or paint well and is a very good artist. He would be a good man to put up some Waders to replace those poor ones that have been in the Snithsonian so long. He wonld be a good man to go to IIndson Bay to take charge of the meteorological establishment as he is a man of brains, if he would go. Some of the white birds are now just coming into good phumage. I saw one yesterday with good plumes, but only one in a dozen. This is a nice place to collect, to go out on the cars in the morning, return in the evening. I am going ont quail shooting tomornow; was ont twice last week. Should be pleased to see liidgway down here; it would be a much better place for his spring vacation than out at Illinois where he has been the last few years. A vacation fol yon would not hurt you as you have not been down here to look after the fish fol some years. 'Ihis State is full of little ponds and lakes, some large lakes, but the small ones could be drained and fish killed out and carp could be raised by the million. 'The cars ran over' an alligator a few days ago, that was trying to cross the track. One of my Florida friends, Wm. Foster of Clifton Springs died last week. We may not go west to live; go out next season to visit and then go back to Calais where we liave a nice place. I think we would be more at home down east. Mrs. P. joins in much love to yon and Mrs. Baird, Lucy and all the friends. Sincerely yours,

G. A. Boardian. 
10 OAk Grove st., Minneafolis, 28 June, 1886.

DEAR P'ROFLSOR:

A good many years ago you told me to be sure and write you every month and now three or four months do not appear longer than a month used to.

I came ont hre with Mr.s. B. the first of May and the children are determined not to let us go away, but we lope to he home in about tluee weeks. 'This is a great country and growing very fast. 'The hoys are all doing very well. Ilave nice places and kerp good teams and we enjoy onrselves very much.

DEAIR PROFESSOR:

Calais, Maine, July 23, 1886.

I thought I wrote yon from Minneapolis, but upon my return home find a piece of a letter started for you among my papers. 1 was so busy doiug nothing out west I did not attend to things very well. We loft for home 12th July and arrived home last 'luesday. We spent a couple of days at Kemelomkport and found Capt. Bendire there at the hotel. IIe appeared to be enjoying himself very much. IIe is on his way east and promises to make a visit at Cakis and shall he rery glad to see him. lle is to spend a week or two at 11 onnt Desert and then eome east.

I did not see much that was new in the way of natural history. A taxidemist, F. I. Tappan of Minneapolis, had a black Wild eat, Lynx Rufus, that he got in Florida. It was black all over as much as any black fox, hut you could see the spots a little on the sides. If it had been in any lind of order for momnting I would have got it for you, but the fool had ent of the feet to make a rug, also the head was gone. He has the skin, if of any use I eould get it for you.

Did you ever have one?

We find everything all right at home. My man and woman took good eare of everything. Frank 'lodd tells me salmon are very searce this season, only about a dozen taken with fly. 'Tliey eannot be expeeted plenty every year.

'lhere is a large erew at work pntting water works in Calais, Milltown and St. Stephen. Ilave taken my farm upon the hill for a reservoir and things look quite lively about town. We expect Charles and family next week. Ile tells great stories 


\section{THE NATURALIST OF THE ST. CROIX}

about his new eity at Charlotte IIarbor and says we must all go down next winter.

With kind regards to you, Mrs. B., Iney, in which Mrs. B. joins.

Sincerely yours,

G. A. BoARtiman.

Dear Professor:

Calais, Maine, Sept. 5, 1886.

I received a letter from Capt. Bendire, writteu Augnst 12, saying he wonld be in Calais the next week and see me. It was written in Bar Ifarbor and I wrote him to be sure and come along. Have not heard anything from him since. Hope nothing has happened to him.

My friend in Minmeapolis wrote me he wondd send you the skin of the black Lymx. He has had it tanned and will be a rare skin for your fur collection. I was very sorry he cut ofl the head and feet to get it tamned but it was poorly skinued and he did not know the rarity of it.

1 hope Capt. Bendire may come along.

A man by the name of I'rof. S. F. Baird said, or wrote that he might be down east this season. If you see him please say to him to hurry along as the season is fast going awat

We are having nice weather. Charles' fanily are with us but he is now in Boston and is expected down iu a few days.

With kind regards to all the folks, I am

Yours as ever,

G. A. BoAritian.

Letter from Mr. Boardman to Mrs. Baird.

$$
\text { Multown, } 19 \text { Sept., } 1869 .
$$

MY DEAR Mrs. BAIRD:

I commenced to write to the Professor but I am so cross to think he should return home in such a way as not to come to see us again, I don't think I shall wite him again, until I feel better natmed about it.

1 remember those bad names he told you to call me, for not going over to Grand Manan with him, I wish you would multiply them by ten, and then put them all on him. 



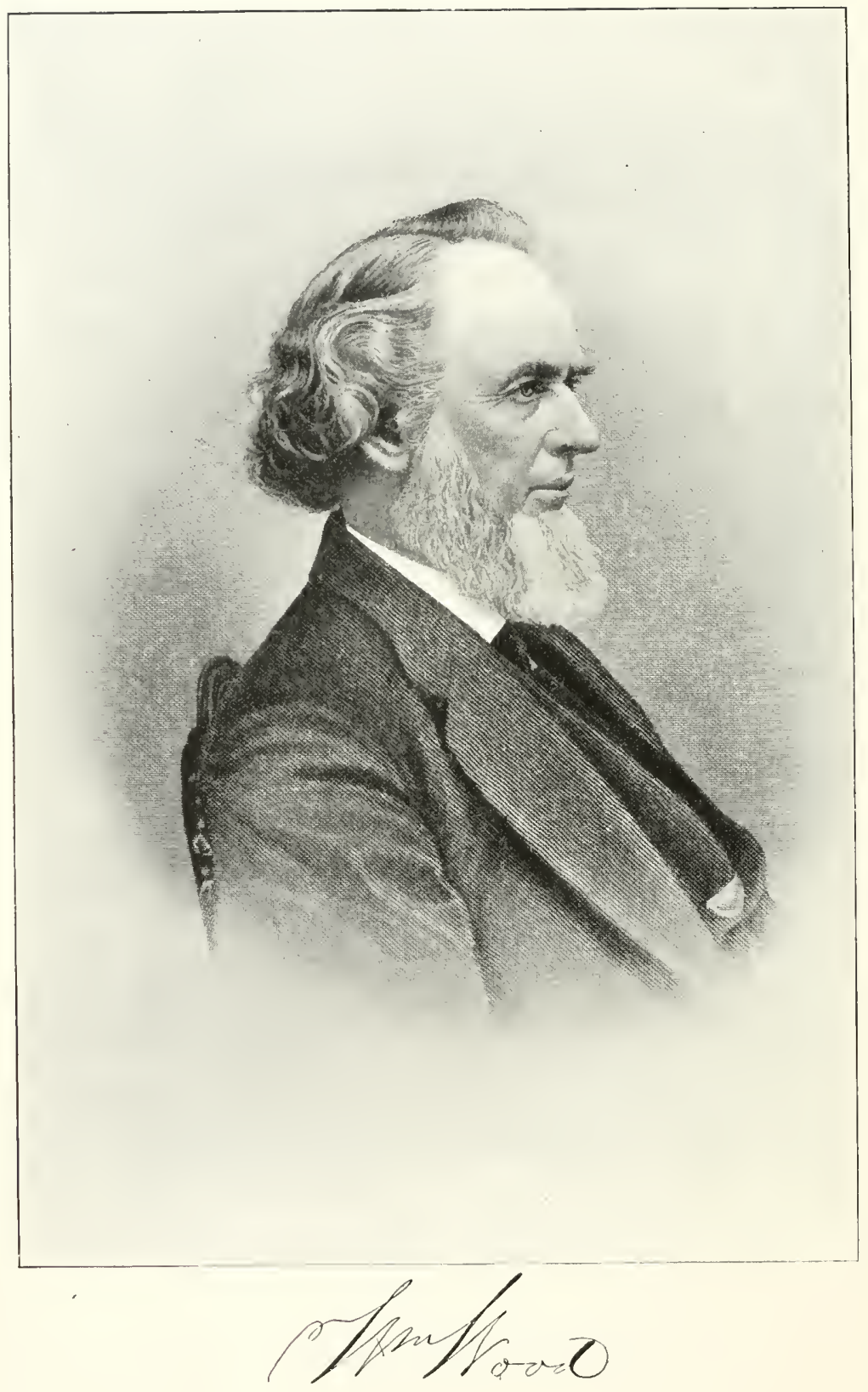


We certainly expeeted another visit, if only of a few days.

We expect Georgie will leave for houne Monday; she harl a very nice trip on by land, enjoyed it very much, expect she will return by boat, if the weather should be gooll. Ifope you maly have a pleasant passige.

With much love to Incy and only a little to the Professor this time, I aul

Yours very truly,

Geo. A. Boarminan.

One of Mr. Boardman's most intimate correspondents was Dr. Willian Wood of Liast Windsor Hill, Connecticut, one of the most eminent naturalists which that state ever produced.

William Wood, the son of Rev. Luke Wood, was born in Waterbury, Conn., July 7, 1822. He received his early education at the acadeny at Old Killingworth, now Clinton in that state and under the private tutorship of Prof. Marsh and Prof. Loverin, in Vermont. He was qualified for the senior class at Yale, which he had hoped to enter and graduate at the age of seventeen, but failure of his eyes, which had been overtaxed in study, prevented the realization of this hope. He then engaged in teaching, studied medicine, attended lectures at the Berkshire Medical College, Pittsfield, Mass., and at the University Medical College of New York, from which he graduated in 1847. On November 9, 1848, Mr. Wood married Mary Lyman Ellsworth. She was a daughter of the late Dea. Erastus Eillsworth, member of one of the famous families of Connecticut and was himself one of the principal founders of the Theological Institute at East Windsor Hill. Immediately after his marriage Dr. Wood settled at East Windsor Hill where he continued to reside 
throughout his long and active professional and scientific life.

Dr. Wood was very enthusiastic in the study of natural history, giving special attention to the study of ornithology and oology in which he made large collections. In taxidermy Dr. Wood had few superiors and his collection of nounted birds and their eggs was widely known - being the largest and choicest in private hands in the state of Connecticut and one of the largest in the country. In a special building upon his home grounds he had his office, while the larger part of it was used to house his extensive collections of natural history specimens, Indian relics and other curios. 'The collection was always freely show1 to all visitors by some nember of the family, without charge. Dr. Wood was an occasional contributor to the American Naturalist and wrote a series of articles on the Rapacious Birds of New England, publislied in the Hartford 'l'imes in 1861. Upon this subject he was the leading authority. He was an honorary number of the Lycenm of Natural History of W Williams College and a corresponding nember of the Nuttall Ornithological Club of Cambridge, Mass.

From a memoir of Dr. Wood contributed to the Report of the Connecticut Medical Society by Dr. S. R. Burnap of Windsor Locks, the following extract is taken :

Ur. Wood was a man of a very genial and friendly nature, warm and hearty in his greetings, and especially enjoyed meeting his professional brethren in the several medical societies with which he was connected, and wonld be at much pains and inconvenience rather than be absent on those occasions. He was one of the two or three organizers of the llartford County Nortl Medical Association some twenty-eight years ago, of which he was secretary from the time of its organization till his death. 
Although lie devoted much time to the stuly of the natural sciences, for which he had great taste, I think he did not do this to the negleet of his medical realing. He was a man of great industry and atcivity, and an early riser; and by a systenatic use of his time wat able to gratify his tastes without neglecting his duties as a physician. Ile took a lively interest in his patients, was prompt and faithful in lis attendance, kind and gentle in his manner, wam in his sympathies, aud evidently eamest in his rndeavor to do them good. In this waly he merited and won the contidence and estrem of the many families who, in times of peri], were willing to trust thrir health and their lives in his hands. As a citizen, he was interested in all that pertained to the best interests of the community in which he lived; was a nember of the Congregational Chureh and for thirty years leader of its choir in musie, being rarely absent unless when compelleal by urgent professional duties. Ile was a most agreeable person to meet at his home or elsewhere. IIe was a good talker and had a large fund of aneclotes; coukl tell a good story and enjoy a hearty laugh. He was maturally domestic in his tastes ant was most happy in his domestic life.

Dr. Wood died, after an illiess of but three days' duration, August 9, 1885, in the sixty-fourth year of his age. An obituary notice in the Hartford Daily 'Tines of August 10, 1885, said: "He was a well-informed ornithologist and quite an artistic taxidermist. His collection of specimens of native and foreign birds is large. Dr. Wood's opinion was taken as authority by ornithologists of distinction, and his writings on the birds of this region will be held as valuable in the future." In an obituary notice in the editorial columus of the Ornithologist and Oologist, for September, 1885, Volun1e X., No. 9, occurs the following tribute: "Few nannes are better known in the ornithological world than that of Dr. Wood. A well-know11 pliysician in the state to which 


\section{THE NATURALIST OF THE ST. CROIX}

he belonged, he was more widely known as an enthusiastic naturalist, and especially as an ornithologist whose opinion was widlely sought and universally respected. He was also a taxidermist of large experience and talent. $\mathrm{H}$ is collection of birds and eggs both native and foreign is one of the largest in private hands in the country. A large proportion of them liave been prepared by his own lands. His writings liave consisted principally of communications to local and other papers mainly on the birds and fishes of New Eingland. He also contributed to some of the earlier volumes of this Magazine, but of late he confined himself to occasional notes on subjects which were being discussed."

In 1896 Mrs. Mary Iillsworth Wood, widow of Dr. Wood, presented her husband's entire collection to the Hartford Scientific Society and it was deposited in the rooms of the Wadswortl Athenæum. A full and nost interesting description of the collection, with illustrations, was published in the columns of The Hartford Courant, November 18, 1896. In 1902, when the collection was opened to the general public, an account of the same also appeared in the colnumns of The Hartford Times, July 7. The collection is nunder the care of Albert C. Bates, librarian of the Connecticut Historical Society.

Mr. Joln H. Sage of Portland, Conn., writing to Mr. Boardnan August 19, 1885, regarding Dr. Wood's death, says: "Yes-it is sad to think our good friend Dr. Wood has left us. I was thmuder-struck when I took up the paper and read the notice of his death, liaving had a letter from him only a few days before. He died at six o'clock Sunday morning, Angust 9, aged 
sixty-three. He was out fishing the previous Thursday when lie was attacked by severe intestinal trouble that had afflicted him for many years. His daughter told me that he said he sliould not live. He appeared to know what they were doing for him but spoke very little during his sickness. We were the best of friends and I shall miss his ever-welcome letters and the opportunity of consulting him occasionally as has been my habit for years. He had a large collection of birds and eggs, many Indian relics and fish. I lope his collection will be placed in Hartford. It was especially rich in local rapacious birds. His series of rough-legs is very valuable."

'The correspondence between Mr. Boardman and Dr. Wood connmenced September 20, 1864, and continued until September 30, 1885. Dr. Wood wrote the first letter at the suggestion of Mr. J. A. Allen, saying: "My object is to open an exchange with you of skins and eggs and I trust I need make no apology for addressing one engaged in the same pursuit as myself." Dr. Wood particularly wants eggs and in this letter gives the numbers (according to the Baird Snithsonian list) of the eggs of one hundred and eleven species which he has, fifty of which are of foreign birds. Mr. Boardman answered this letter inmediately upon its receipt, writing one of the most interesting autobiographical letters he ever penned, telling how he began the study of birds and what he had, saying it was only within a few years that he had cared for birds' eggs. "I have found quite a number of good eggs this season," he writes, "but have had so many visitors they have taken the most of them away." Yet he writes that he has all but eight of the list enclosed by Dr. Wood. 


\section{THE NA'TURALIS'T OF THE ST. CROIX}

During the continuance of this correspondence fiftytwo letters were written by Dr. Wood and sixty-nine by Mr. Boardman. The collection is rich in natural history facts, for both were rare observers of the ways of birds and most entertaining letter-writers. Interesting personal incidents also occur in nearly each one. Wherever Mr. Boardman was he kept up his correspondence with his friends. He wrote from his home in Milltow11, from places in Florida where he spent the winters, from Boston, from New York, from Washington, from Minnesota and from California. The letters are all original. There are no duplicates in Mr. Boardman's letters though written to so many different persons and generally upon the same subjects.

Dr. Wood writes in 1864 that he has not been able to get the eggs of the Duck Hawk "although I visited the cliffs, some fifteen miles from here, four times last spring for that purpose. The birds that were described in cliapter fifteen of my Rapacious Birds of New England, I kept alive two years, and when Prof. Baird was here I gave them to him. He took them to Washington to note the change in plumage but they soon died." Writing to Mr. Boardman May 17, 1865, he tells of his collectors who climb trees after the nests of the Red-tailed Hawk, in this interesting extract.

I expect to start on a trip of thirty-two miles next Monday to collect the eggrs of the Night IIeron. One of my collectors aceompanies me to elimb the trees. 'They nest here in great numbers, 1,000 or more. I wish you were here to go with us. It is a sight worth seeing to go into that heavy timbered swamp and see it alive with them. Almost every tree has one or more nests upon it. I went there some four years sinee but found the young so far advanced that I did not get but a few poor eggs. Hope to 
do better this season. My collectors have done wall this spring and I expect to get a good many duplieates for exchunges. One of my hunters who hives some twenty miles from me sent me word when I was sick that he hat found two nests of the liedtailed Ilawk, but conhl find no one who dared climb the trees. If I had been able I should have gone out with one of my elimbers who says "he can climb any tree made of wood," and I believe he can. Ife makes no more eflort apparently than a squirrel. I have seen him go up sixty or aighty feet and swing ofl with nothing but his feet to hold him - head down and then swing back.

"'The Wood Pewee," writes Dr. Wood on March 11, 1867, "does not nest in the sane spot when broken up, but very near it. There is a grove of one and one-half acres back of our garden and the pair wotnld not leave that grove no matter how many times I took their eggs." May 7, 1868, Mr. Boardma11 writes him: "I told my friend Mr. Krider of Philadelphia, who is a great collector and a very nice man, to get acquainted with you. He has a good collection and time to pay attention to the egg business, and does not have two hundred workmen to keep employed. In about ten days, or after the lakes are open, I expect to go up country fishing and look after some tree ducks. The little Buffle Head Duck is with us all the season and breeds in holes in trees, but I have never been able to get the eggs. Baird has them but I prefer to get them liere if possible."

On May 18, 1868, Dr. Wood writes: "I have obtained one very singular set of eggs that I am unable to decipher - one of my collectors told me that he had found some very singular crows' eggs. He saw the crow building the nest in the top of a tall pine and after a week or so he obtained four eggs. They are the shape and size of rather small crows' eggs, but are marked like the eggs 
of the Chewink, with reddish-brown spots, no green or bluish color about them. What are they? Does the Fish Crow lay such an egg?" Mr. Boardman answers by saying: “' 'The crows' eggs were marked very oddly but I have seen crows' eggs of most all colors, nearly white and also quite brown."

Dr. Wood was a delegate to the Vermont State Medical Society at Brattleboro in July, 1868, and on his return in the train he saw a good looking man reading the American Naturalist. He writes Mr. Boardman: "On the strength of that I ventured to ask him if he was a naturalist. He replied that he was fond of botany and that he had now been up into Vermont to collect a very rare plant which was only found on an island in the Connecticut river in the northern part of the state. I found he had travelled all over this continent as well as on the Atlantic and Pacific Coasts. After considerable yankeeing I found out that he was Prof. Alphonso Wood, author of Wood's Botany. We had quite a lively time after we found out each other's names and that we were distantly related." In a subsequent letter, under date of October 9,1868 , Dr. Wood gives the conclusion of this interesting incident :

I sent Prof. Wood, author of Wood's Botany, a box of botanieal specimens last week. We have a plant, Lygodium palmatum, the elimbing fern, which is very abundant here but is not to be found anywhere else on the globe in any quantity. 'There is one place in Massachusetts where a little ean be found. It is one of the rarest plants in the world. I was telling Prof. Wood of the abundance of it here, last summer, and he was anxious to have me send him not only some pressed specimens but some roots. He intends to transplant it. I sent him over tifty good roots and some twenty-five pressed specimens. Prof. 
Gray of Harvard sent for a box of specimens; Prof. Cladbourne also. Prof. Eaton of New Haven eame np here to sce it growing and gather some. Ile hal never seen it, althongh he was professor of botany. I took him into the woods where it was as thick as it could stand. When he saw it, he took off his hat and swung it, exclaiming, "I am ready to die now!" A little enthusiastic.

"Have you seen the Angust Naturalist?" Dr. Wood inquires in the same letter. "When Allen was writing for the Institute proceedings, he visited ne and wanted a set of my articles on the Rapacious Birds of Connecticut, which I gave him. 'This month's number contains an article from him on the Screech Owl - the whole of which, almost, is copied from my article witl a little change in phraseology but without giving me any credit for it. I would not care were it not that Putnam wrote me while the discussion was going on in the Naturalist regarding the Screech Owl, requesting an article from me. I forwarded him my article with slight alterations which he has accepted and the proof is corrected. The article will appear in the September or October number and to those not knowing the facts it will appear as though I had taken my facts from Allen without credit. I an very sorry on this account." In a letter to Dr. Wood on December 9, 1868, Mr. Boardn1an writes:

The Red Throat I wrote you ahout was brought into a taxidermist shop in North William Street, New York, when I was there; Mr. Wallace mounted it. 'The man shot it in the sonnd, but did not say at what part. The red was not very rool but would have been in a very few days. I think in winter they do not have the red-throat, but all I get as late as the last of April or first of May have the throat red. I never saw a white throat bird late in spring and never a red one in winter. I noticed what yon say about trusting to the gunuers for names of the dillerent kinds of birds. 'They always see or shoot some wonderful birls, such as have never' 


\section{THE NATURALIST OF THE ST. CROIX}

been seen, but they most always turn out some common affair. I wish you could spend time to go south with me this winter. I generally call to see all the naturalist folks in New York, Philadelphia, Washington, Charleston, ete. You would enjoy Floridathere are so many new things to see at cvery place you go.

Among the interesting things in Mr. Boardman's letters are the following: "I have never had much experience with the Red-tailed Buzzard or Hen Hawk. They are not plenty with us but $I$ have seen them in all the plumages you name and have thought it took several years for them to mature. It is the same with most all hawks. It is also the same with eagles but owls appear always about the same. It takes three years for the Eider Ducks and about the same for the Herring Gull to get into full plumage. I do not know of any good description of its change of plumage." Writing from Jacksonville, January 17, 1881, he says: "After receiving your letter telling me your friend thought there were but few birds in Florida, I took my gun and $\operatorname{dog}$ and was not gone from the hotel two hours but I brought in nine W ilson Snipe, one Quail, one Killdeer Plover, Larks, Ground Doves, Carolina Doves, one Clapper Rail, Cardinal red bird; while I also saw Robins, Red-shot1dered and Sparrow Hawks, Pewee, four kinds of Warblers, three of Woodpeckers, 'Tit-larks, Creepers, Buzzards and black Vultures, Bitterns, dozens of Sparrows, Shrike, Mocking birds, several Terns and Gulls, lots of Ducks, Chuck Wills Widow, and all within a mile and a half of Jacksonville Centre. A few years ago I came down with my dog from up country to the hotel here and found lialf a dozen men with guns and dogs who said they had been here all winter and found no quail. Three of us went out the next day and brought home ninety-two 
quail and some other birds. I find birds and game plenty in Florida but they do not come into hotel parlors very often." On the habits of birds he writes : "I had not long since a live Goshawk in my barn chamber. When he was on the beams, if I threw a stick at him, instead of stretcling ont his neck like a goose or duck, he would draw down his head and throw up his shoulders or wings." About the Golden Eagle which Dr. Wood had reported having, he writes November 30, 1879: "You got a prize in your Golden Eagle. They are now very rare in any part of New England. I have not heard of one being taken here for some years. The last two were caught in steel traps."

"I cannot tell you much about the breeding of Richardson's Ow1," Mr. Boardman writes September 5, 1879. "They are not nncommon here late in fall and winter. The Arcadian Owl breeds. I liave never found the eggs, but once I fonnd the nest and young. The nest was in a hole in a stub not more than five feet high. It was the first of June and the birds were abont half grown. I did not connt them, only took ont two birds, but there m11st have been five or six."

One of the points upon which Dr. Wood wished information was the period of incubation of the Osprey. He was writing upon the subject and was searching everything of value in ornithological literature to find ont, "in order to make my article perfectly reliable. But there is not a work extant, so far as I can learn, that gives the desired information. I have written to oological collectors withont avail." In answer to a letter written to Dr. Brewer asking for the period of incubation of our rapacia, he replied: "I am very sorry to 
liave to confess to entire ignorance in regard to the time of incubation of all the species." Dr. Wood quotes Mr. Gentry in his work on the Birds of Eastern Pennsylvania as making all the birds in the family occupy a different period, spending only one or two nights in building a nest, and writes: "I watched one this season which took five days. Perhaps Connecticut birds are not as smart as Pennsylvania birds. Gentry is very particular to have each of the six owls occupy a different period of incubation, from fifteen to twenty-fonr days." In answer to a request for Mr. Boardman's views he writes:

In answer to your question about the time, or period of inculytion of our hawks and owls, I must say that I know but little about it, but most every set of eggs I talke I find them in diflerent stages. 'The truth is, we have so many erows, black hirds, jays, cnckoos, etc., etc., that as soon as the hirds begin to lay one bird has to remain on the nest for protection of the eggs and the first latil eggs are much more advanced than the last. I find this in the eggs of small birds as well as of the large. I took last night a nest of Red-bellied Nuthatch made in a hole so small that nothing larger than a monse could get in. Out of six eggs three were nearly fresh; of the others one was quite hard set. I have found in a grebe's nest, fresh eggs and young birds. So to wet at the period of incubation we should have to count from the first eggs in case of most of our birds. 'I'hat may be the reason Mr. Gentry has so much difference.

Another matter about which these naturalists liad considerable correspondence was whether the Black and Rough-legged Hawk were one and the same species. As early in their correspondence as 1868 , Dr. Wood had asked Mr. Boardman's views upon this subject and in a letter dated October 12 of that year he writes:

About the Black and the Rongh-legged Ilawk being the same bird, I would saly I have some donbts and some of the reasons are 
these: The Rough-legged of Europe is thought to be the sane as the American birl in size, color, habits, eggs, nesting, ete., ete. Its history is well known from the time they breed in Lapland to their winter quarters in Central Europe. Never a blackbird has been fouml. At the Smithsonian at Washington they have had at least a bushel of liough-legged IIawks' eggs, all sent with the parent bircls. 'There was never one blaek hawk in the lot. Now if, as you think, the black is the alult, how does it happen that a black birt has never been seen in Europe? Or more strange, that all breeding birts sent to the Sulthsonian should be young, not one adult? The Jlack Hawk is not at all uncommon in Labrador in summer. 'The liough-legiged I cannot hear much about. 'The tishermen never bring me any, but up at Slave Lake and on the west coast the Rough-legged is abunlaut, more so than any other hawk, but the black is very rare. 'I'hey are neither very common with us. I have good specimens, however, of each, and they appear to be of most all colors. Most of the black ones I have collected I have sent to a friend in London for purposes of comparison with their Rough-legred. They conclude it eannot be the same birl. $\Lambda$ s they have better oruithologists than I ever expect to be I must agree with then. I would be glad to see the list of species of birts much redued, but the man who should undertake to do the thing must be prepared for the work or he would certainly have to back lown.

\section{On December 14, 1874, Dr. Wood writes :}

Ilave you seen Baird's, Brewer's and Ridgway's new work? I see they consider the Rough-legged and Black IIawk the same bird, but Baird makes no allusion to my being the first to positively settle that disputed point. Baird for years contended that they were distinet speeies as confidently as my friend lown in Maine and letter after letter passed between us on that subject. Some years since when he was at my oflice I showed him the various changes in plumage from the young to the adult - still he would not own up. $\Lambda$ llen came on at the request of $\Lambda$ gassiz to see my series and was convinced I was right. I sent to the Cambridge Museum three specimens, young, immature and black IIawk. Allen wrote an article in the Naturalist giving me the credit of 


\section{THE NATURALIST' OF 'THE ST'. CROIX}

settling the illentity. IBaird came up here to see the Great-footed hawks which I was raising, settling the point of their nesting in Connecticut. I gave him two which were kept alive in Washington another year. My birds were kept in Hartford by Mr. Moses as food could be more easily procured for them there. I took Prof. Baind down there where there were three alive aud told him all about capturing them, ete. In his work he gives Moses the credit of being the lonor. I hope others have got the credit due them, but perhaps he may be like $\Lambda$ gassiz who claimed every new discovery by his pupils as his, beetuse they were pursuing investigations under his directions. His students nade bitter complaints and had reason to. Every man ought to be eredited with his own discoveries.

In 1879, writing of this subject again Dr. Wood says : "I regret that I- have not a duplicate of the May number of Familiar Science to send you, containing that chapter of my work on the Rapacia where I take up the Roughlegged Falcon-a point on which nyy views were at variance with those of all the leading ornithologists of this conntry and now my views are endorsed by all without giving me credit. I do not claim to be the first ornithologist who considered the Rough-legged and the Black Falcon identical. I give Audubon and Wilson due credit, but I do claim to lave settled beyond dispute that our later ornithologists were mistaken in making two species of them. It is a pity that some persons who know a little about birds - like your Portland man and other writers for the press whom I might name - should attempt to do what they know nothing about. It fills our ornithological literature with blunders which are credited as facts and copied all over the world and it takes ages to rectify their mistakes."

The correspondence of these two friends is most intimate and confiding. Not only are their letters full of 
interest to bird-lovers, they are taken up to considerable extent with matters of friendship. They are always planning exchanges of birds and eggs which neitler does not have and are ever on the lookont for rare things for each other. Dr. Wood is complaining of the Naturalist because it does not contain more about real natural history and less of the hobbies of the editors; while Mr. Boardman praises Forest and Stream, the Nuttall Bulletin, " no loorse, dog or fish in it," and the Einglish bird journal, The Ibis, saying "it pays well and we should be able to support a bird paper on this side." His friend has many complaints of the Smithsonian people because they do not pay better in exchanges for good things sent them and for their tardiness in sending promised specimens, while Mr. Boardman is true in his friendship for them, always has good excuses and apologies, tells how much they have to do, what a hurry they are always in and that they will finally make exchanges satisfactorily, "but of course the large musetmins and the big collectors must be attended to first." Boxes of exclianges are constantly being sent between them. They tell each other of their losses, their unfortunate investments and their plans for the future. "If I ever get enough ahead to bid good-by to pills and physic and devote ny time to natural history you will see one happy man who will some day turn up somewhere near Milltown, N. B.," writes Dr. Wood; while in a letter of July 31, 1882, he says : "I wish I had the time and means to travel about and enjoy life as you do. I intended to give up practice at sixty and devote the remainder of my days to following my favorite pursuits and seeing my ornithological friends - a desire I have looked forward to with a great deal of 
pleasure - but sixty has found me this month tied up closer than ever, cheated out of $\$ 40,000$ by those I supposed honest men. It is "no use to cry over spilled milk' but it does not make one feel particularly amiable to have his plans frustrated at my period of life by the acts of another."

Notwithstanding their close friendship and long correspondence these friends never saw each other. Mr. Boardman was always writing Dr. Wood to visit him at Milltown, to go to Florida with him, while the latter was constantly entreating the former to stop over on some of his trips from Boston to New York or from Maine to Florida and see him and his museum. He is telling him how to take a stage from Hartford for East Windsor Hill, and then of a railroad to be built which will have a station within lalf a mile of his house. In April, 1873, they liad been in New York on the same day and had visited Wallace's within half an hour of each other and great was the disappointment of both when they found it out later. "Dr. Holder, superintendent of Central Park, spent an afternoon with me last week. He asked if I was acquainted with Geo. A. Boardman of Maine; I replied, 'yes, intimately for about sixteen or eighteen years, but never had the pleasure of seeing the gentleman.' I explained when he said: 'You remind me of him every minute.' So I think it must be about time to see each other face to face. I did not understand him that there was any personal resemblance between us, but that our enthusiasm and manner of speaking were alike."

In 1882 Dr. Wood writes: "I hope you will not go out west to live until you have been here. If you get 
so far away I shall give up all hope of ever seeing you this side of Jordan;" while in 1885 he says: "Now you are back from the south at your old home I hope to hear from you oftener, if I can't see you. But why in the world can't we see each other before we die?" 'The main reason why Mr. Boardman did not visit Dr. Wood, was because his trips between Boston and New York were nearly always made by boat. He was an owner in the lines, a director in one of them and was always at home upon the boats, enjoying their freedom and preferring them to the train. Moreover, in going by rail, as he occasionally did, Mrs. Boardman was generally with him, often some of the boys and, as he says in his letters, he had so much baggage, traps of one kind and another, and generally dogs on his journeys to and from Florida, that it was not convenient to stop over. The two friends ever lived with the hope of seeing each other sometime, a pleasure that was, however, never realized.

\section{Extracts of Letters from Dr. Wood to Mr. Boardman}

East Windosor IItL, March 4, 1868.

I have heen hoping all winter to see you here and give gou some eggs. I don't know what you wish, but if you will refer to my list that I sent you I will let you have anything of which I have duplicates or which I can replace if I have not duplicates. I keep the Barred Owl's egg sacred for you althongh urged strongly to part with it. One oologist told me that if I should live seventyfive years I should not probably find another about here. I hope you will visit me the coming season and we will look over things and have a good time generally.

I have done but little in the way of taxidermy this winter, everything in the way of birls has been scarce exeept Goshawks, the first time in twenty years that I lave been able to get one. 'Lhis winter I have received six and have known as many more 
killed abont here. They are the boldest and most daring of any of our rapacions birds. One of my patrons told me that he eut off the head of a fowl and threw it down and while fluttering within a few feet of him a hawk dove and pieked it up, flying a few rods and then went to eating it. He shot it and it provel to he the Goshawk. Another told me that a hawk pursued one of his hens into the back part of his house, through the door that was open. IIis wife placed herself in the doorway and he ran to the reseue of his fowl with a stiek. The hawk evading the blow attempted to fly out of the door and was seized by the good dame and dispatehed without court or jury - regular lyneh law. IIave you duplicate eggs of them?

I have obtained one Snowy Owl - the first in three seasons. This was killed some sixteen miles to the west of here and sent to me. I caught the young of the Crested Grebe (the adnlt never comes here) and hoped to keep him alive until in full plumage. There is a small stream some two miles above my ofliee over which is built a blacksmith shop and at this part of the brook are springs which never freeze. I made arrangements with the blaeksmith to take eare of him. He fastened a eord some two rods long to his leg so that he eonld swim uncler the shop or outside at his pleasure. Ile beeame quite tame, but unfortunately one night he got hung by his eord and was found dead in the morning. I kept him about two weeks in this brook and if he had lived I should have made a fence along its bank for a few rods with a sieve at the ontlet so that he eonld not get out. One very eold night the blacksmith earried him into his eellar and gave him bread crumbs to eat. IIe said they were all gone in the morning. birl the grebe eat them? He used to throw corn in the brook and that would all be eaten up. He sail the grebe ate it! Can that be so or did something else eat it $u p$ ? I asked him if he was sure that the bird ate it? Ite said, "Yes, for there is nothing else to eat. I throw into the brook a handful of corn every morning and when I come out after a while it is all gone." If the bird had lived I should have satisfied myself upon that point. Perhaps you can give me positive information on the subject as no doubt the grebe is common with you but is seldom seen here. 
November $6,186 s$.

IViuter has begun in good earnest. We have had two snowstorms but not much of depth. The winter birds lave begun to make their appearance and some varieties that have not been seen for many years are here. 'The Goshawk is about again this year. I have just received a very fine speeimen - this is the third taken within a slort time near here. I have received two speeimens of the White-winged Crosshill within a few days - a very rare bird here. I have not known one here hefore for fifteen years. 'That season they were very ahundant. 'Two specimens of the Pine Grosbeak were shot on 'Taleott momntain this week, but fell into the hands of a naturalist in IIartford so I did not get hold of them.

I notice what you say about the Rough-legged Faleon and Black Irawk. I have corresponded with several ornithologists npon the sulject who have had the best opportunities to know. Wm. Cooper of Quebec, who is a thorongh naturalist, says that he has been investigating the subject for years and is very positive that they are identical. IIe says if they are distinet why has not some oologist been able to identify the eggs of the Black IIawk? I may be wrong in considering the black the adult - it may be the young. I think they are the same bird. The size, form, habits and everything pertaining to them are the same. 'Ihe markings from light to dark or dark to light run into each other and are as noticeable as the elanges of the Goshawk. 'The fact that the Rough-legged is abundant in some sections and no Black hawk and vice versa, is no proof against their being identical. We see the same thing in many varieties of birds. 'The young of the Red-throated Diver is very abundant in Jong Island Sound, yet the adult bird is never seen there. The young of the Crested Grebe is found bere; the adult never.

February 4, 1869.

I shot a splendid male Golden-eyed Dnck last Friday but lost him under the ice. 'The Scantio river empties into Connecticut river a short way above here and being a quick stream and dirty, cuts quite a strip open in the Connecticut long hefore the ice breaks up. Friday being a beantiful warm day I took my gun and went to this "ope." I found it open some three miles on the 


\section{THE NATURALIST OF THE ST. CROIX}

Connecticut and six lods wide. I saw a Golden-eye some way above and attempted to get up to it by running when it was under the water. $\Lambda$ t my second ruu the snow gave way, throwing me headlong and running my gun barrel nearly its whole length into the snow. $\Lambda$ fter getting my shooting iron in order my game was gone. Proceeding farther down I saw two more and after several hours I succeded in shooting one. I took out my line (which I always carry to throw over game in the river) and attaching a club, threw it oyer the duck but it was not heavy enough to hold the specimen. Pulling in my cord I found it twisted and knotted into every conceivable "tic up" imaginable and before I could get my line in working order the bird was some one-half mile below. Overtaking it by a high clay bank and sceing it near the shore I attempted to descend-slip, slip, and down I went into the mud and soft clay and did not stop until I fetehed up in aqua fortis. Fortunately it was not deep enough to seriously wet me. Before I could extricate myself from the clay my bird was again below me and out of reach.

Determined to have it as it was a splendid male speeimen, I followed to the end of the "ope" (three miles), thinking I should eertainly get it then, but what was my disappointment to see it disappear under the ice! 'The first male specimen I ever got I swam into the Connecticut river after in December when there was ice on the shore.

July $15,1869$.

Last week I heard of a man in Massachusetts who had found the nest of the Great IIorned Owl with two eggs. I thought I would see if I could not be as smart as some folks in Maine who go wading through swamps in a drenching rain to get the egg of the Broad-winged Ilawk! I immediately dispatched a man for them so as to be sure of getting No. 45 for G. $\Lambda$. B. But judge of my disappointment after sending a man fifty miles, twenty in a wagon and thirty in the cars, to find that $\Lambda$ mherst College had got the start of me and procured the eggs! It is the most diflieult egg to get that is to be found in this seetion. I think I mentioner in one of $\mathrm{my}$ letters that one of my collectors found a nest with young in it this season. I told him not to disturb it, hoping to get the eggs next year. The first egg l get you shall have. I never 
liave heen able to get but one egg. The man who found the nest saw the old bird on and supposing it was a hawk which had made himself ynite at home among his chickens, fired into the nest and out eame the owl, winged. IJe then climbed the tree and found five eggs, four of which were broken to pieces; the good egg he gave me. The nest $I$ think must have been in quite an unusual place. It was in a eluster of small yellow pines not more than thirty or forty feet from the ground. 'Tho Duek-liawl's eggs which Allen told you about I have. 'They are all malked very much like the egg of the Fish-harve and are considerably larger than the egr you let me have.

I hope your son will secure a good lot of eggs in Vermont. The Hawk Owl nests there, I am told, abundantly, in some sections and the Bald Eagle nests abont Iake Champlain. $\Lambda$ gentleman who visited there told me that several pairs have nested there for many years. I want very much to get the Eagle's egrs. One of my huuters who went to Michigan some four years sinee found the nest of the Bald Eagle and climbed to it, and found three eggs in it. He said he thought he would let it be three or four days longer and get four or five eggs. He waited and went to it again and found the nest robbed and torn rlown. I think I should not have felt very bally if he had taken the three without waiting for more. So it is one lisappointment after another.

November 29, 1872.

You ask why it is that most all natmalists are loctors. I have often asked myself the sume question when looking over the Naturalist's directory and seeing who are the contributors to the Naturalist. I suppose it may be aceounted for in two or three ways. In the first place our preliminary studies have a tendeney to develop a taste for the seiences. Second, onr rides through woods and by streams every day of our lives lead us to observe everything in the vegetable and animal world to relieve us from care and we soon become interested in some department of science; and again, we ean collect ourselves and being acquainted over a large circnit we can interest very many persons and get them to collect for us. Every Indian relic and every rare hird or animal or egg that is found within ten miles of me is surely brought to my ofliee. I have just mounted a splendid otter that was killed 
within one mile of my office. It is the only oue that has been taken in this town within the memory of the oldest inhabitants. $\Delta$ re they eommon with you? We lave been trying for the past three weeks to shoot a white crow which has been in our meadows but without suecess.

I made quite an exchange of eggs with Herrick after his return from his northern trip. I lave lately made an exchange with Benclire and hope to get his entire eollection of about 3,000 eggs. I liave made him a liberal offer and am now expeeting an answer. It takes over six weeks for a letter to go and return from his eamp and that time will be up next week.

November 18, 1879.

The bird which I wrote you about at Bolton Reservoir which I guessed was the Black Vulture is no such bird. I went in company with five of my hunters and succeeded in capturing him. It is a salt water bircl, probably abuudant in your section but entirely new to this locality. It was the Double-erested Cormorant. We had an exciting time in getting him. It had been shot at so often that it was very wild. We conld not get within eighty rods of him. When he started, would fly the length of the reservoirthree miles. Fom of us lay concealed while one in the boat kept the hird going to and fro, very high np. IIe was at last winged and I assure you he was equal to a Loon to dive. Last Monday a beantiful adult Golden Eagle was brought me, the first adult bird that ever I have known in this Jocality. I have seen only two immature birds killed in this vicinity in thirty year's. 'This bird captured himself. A gentleman was driving in the highway through a piece of woods within four miles of my oflice and discovered this bird sitting in the road. On apploaching him he discovered that the bird could not fly; that his wing was broken near its body. I have mounted the bird. There was no shot, no blood about the bird. How came it so? I think the wing must have hit a limb. It had just been done. 


\section{Letters from Mr. Boardman to Dr. Wood}

Milltown, 27 March, 1866.

\section{DEAR DOCTOR:}

I liave just received your letter of March 20 and am glad to heal from you.

I have just returned with my wife from quite a long trip down your way. We went as fur as Washiugton, visited the birl men in Boston, New Iork, Philadelphia, Baltimore and Washington. Were absent about five weeks. I saw many fine collections of birds and eggs but since I have got home I believe I like my own little local collection better than any I saw. I came very near making you a call, and had Mrs. Boardman not been with me, think I should have done so. But Mrs. Boardman said I had scen enough for one visit and I thought she was about right. It would not do to see everything in one visit. I hope, however, before very long to be New York way again.

I saw ruite a lot of new things at the Smithsonian which they had received from Kennicott's expedition since my last visit there a few years ago. Some of their eggs I think very good. 'The skins were poorly done np, about the whole value of them was the labels; as for speeimens they were not worth fifty eents a bushel.

I took tea with Dr. Brewer of Boston and looked over his collection. It is very large and nice. IIe is getting ont a new work, the second part of his American Oology, to be published by the Smithsonian. The drawings are very good, mostly of the smaller birds. I hope they will soon publish the work. It has been so long since they published the first part I should be afraid the first eggs would spoil, and the doctor told me they have found out that some plates in the first part were not correctly colored.

I have just had a call to go up to Fredericton for about a week. Some of the English officers are quite good collectors. The governor of the Province is a good naturalist and is a pleasant correspondent. He goes in for live things and has quite a menagerie of bears, beavers, foxes, squirrels, hedgehogs, etc. 11 e sends live things to the public gardens in London. I have found nothing new in the way of birds or eggs this winter. I have had 


\section{THE NATURALIST OF THE ST. CROIX}

some dispute with the bird men about the Black Guillemot changing its plumage in winter. All the books say it does. Not long since Dr. Coues wrote a paper to the Aeademy of Natural Sciences in Philadelphia about the subject, which would be all very nice if true. I get the birds any time in winter in full black plumage. IIoping to hear from you always at your convenience, I am

Yours truly,

Geo. A. Bonrdman.

Milltown, 28 January, 1867.

DEAR DR. WOOD:

I last night received your letter of Jamuary 19 -one week on the passage. I am very glad you are all right again. I have been thinking about you for some time and was afraid you might have had more trouble with your head, but know it is all right when you can be interested in birds and eggs.

I notice what you say ahout your collection of mounted birds. I have no doubt it is very tine, but until I see it, I shall hardly believe it as good as mine. I think I can beat you upon water birls, rare ducks, grebes, geese, waders, ete. I have them in different plumage, and of many of them the chicks. We have a good chance for water birds. My eagles, hawks and owls are hard to beat. I have fifteen different kinds of hawks and ten of owls, of our locality, all nicely mounted. Amongst them are three Gyrfaleons and five Duck IIawks, done up in different attitudes and plumage; seven very fine engles, Golden and White-head, done the same way; my small birds are very good. I have also some very fine horns, lieads, ete.; heads of deer, earibou, moose and some African horns, heals, etc. I ouly mention those to see if I cannot induce you some time to take a trip down Fast. Besicles, I have some very good eggs, but I do not care so much for eggs as for birds. I think a good collection of horns very interesting. I have moose horns that weigh about fifty pounds, five feet wide with thirty-eight points upon them; earibou horus with thirtyfive points, ete. I think you must come! IIow about the snow stor'm? We ean beat you at that. 'The first mail we have had since the 17th of January, a week ago 'Tluursday, ten days, was yesterday. We get telegraph news every clay, as the snow is not quite over the telegraph poles, but it is very deej. I want very 
much to gro to the logrging woods to spend a week or so, but an afraid to sleep in the camps, as I might take cold. l'rof. Bairal is a great fellow for sets of eggrs. 'These big society follis will take all they can get, the most of them by sets or any other way and if we want any sets of them they come very slow. However, I suppose we private folks are not of so much consequence as big European and other societies. I get letters every few weeks from Prof. Baird. Ile hats a big lot of things from the $\Lambda$ retic regions, he salys over 100,000 specimens. I am getting some winter birets' skins for them, also a lot of stermums (breast bones of birds) and hope we shall get a good lot of things from him when he hats time to wait upon us. I got a good box, however, last spring and expect, if I gret time, to gro agaiu, say the last of March and see what he has that is new.

I notice what you say about the Wood Pewee. 'They are very hard to find with us. They build in the deep woods. I never got but one or two. Do you keep nests as well as birds in any quatutities? I think they are very interesting and some of them are very pretty, the Wood l'ewee and 'Thistle-bird and many of the warblers. I had a nest and eggs sent me called the Goldencrowned Wren, with a very pretty nest, nearly one inch thick, male of pretty green moss. I used to throw away the nests, not liaving a good place in which to keep them and besides, they made a great cleal of lirt; moths would eat the feathers and lining, but my glass top boxes keep them very elose. I have only saved a very few and am very sorry I have no more. I must collect nests next year. I am sorry your Miss Pewee got killed. I did not know they would build again in the same place when they were disturbed. Many birds, by taking all their eggs but one, will continue to lay a large number. 'lhe little Red Owl and Sparrow llawk will do so, as well as many of the Woodpeckers.

I did not go after the big Iferon's eggs, I was very busy, and they build on so high trees I did not feel like uudertaking the job. I lad quite a task getting a Duck llawk's egres. I went about sixty miles, half the way in boats. 'There were two nests and I must try to get one more this spring. Were it not for the fun of such an excursion they would cost more thitu they come to. I was. gone over a week with quite an expensive crew. 'They breed very 


\section{THE NATURALIST OF THE S'T. CROIX}

early and most other birds of their class, raven and eagles, breed at the same time. I did not get any small birds' eggs on that trip. Last year I did not try so hard as usual to geteggs. I think I am losing my interest for birds and eggrs. I have the birds very well up, but somehow the eggs come slowly. Hawks' eggs I have got very well, but of owls I have only five species, and one of them does not belong lıere-Barn Owl.

I notice what you say about exchauging. I think perhaps I night lıave some rare sea birds' eggs which you have not, as I have received some good ones from Labrador most every year, but I have forgotten what you had on your list. If you will send the numbers you want, and the numbers of your duplicates you have to spare, when you have time to look through them, I would like to have you do so. 'There are a number of the oflicers at Fredericton who make collections and do not get many egrs of some of your breeders. 'They always wat hawlis and owls such as do not breed this way often. But I have been writing much longer than I inteuded and remain,

Ver'y truly your's,

Geo. $\Lambda$. Boardman.

Milltown, Nov. 17, 1868.

MY DEAR DOCTOR:

I received your weleome letter of November 6 and am always glat to hear from you. 'The eggs came along all right, but I have been away most of the time since I wrote you and have only opened the box. I hope to get time to send the Yellow Red-poll's, as I have a full nest. I eau send them by mail.

I did not go to New York on my last trip, so did not go by you. If I go south tlis winter I shall go the last of next month, sliall probably take my family, in which ease I should not eare to stop. Besides, I should probably go by the Sound boats.

We are having winter very early. The pouds are frozen so liard the boys have had good skating. We have now pretty fair sleighing with three to four inches of snow on the ground. Whitewinged Crossbills are quite common about my trees and I have seen a few Pine Grosbeaks. 'Those with Goslıawks are our common winter birds. 
1 do sot think we know all about the Black and liongh-legged Inawk yet. I clo not saly they are not the same but 1 an a great way from being convincel and I lave taken some pains to corresponl with sone good ornithologists, long ago, who 1 will not say hatve hat the best opportunities for knowing, perhaps not so good as those of your friends. One of them lived north where they are common, where they were the most abuulant hawk, and where it was not an uncommon thing to see a dozen flying about at the same time, for ten years. He said that in his loeality in 1862-63, sixty nests were taken. I have a very minute deseription of eggs, nests, birls young and old. 'I'hey breed very late. He says this hawk varies more in the shading of its coloring than any other hawk. 'Tle female is grencrally lightest, and a very old bird nearly graly. 'The young with baeks light brown, dark band across the belly, under parts white with a few spots, but he says he never saw a black hawk, young or old, in all his residenee among them.

Now I would like to ask your friends who have had the best of opportunities to know, this question: 'That in taking this hawk from the nest in dozens of instances if they ever took a black one, young or old? If they ever saw an old black hawk feeding a brood of young Rough Legs, or vice versa? You say the faet of the liough-leg being abundant in some places, and no black hawks, is no proof of their being identical. I do not say it is positive, but it is good prima facie evidence. When a good collector has lived among them a long time, taken dozens of nests of old birds, of eggs and of young, and there was not one black in all the male, female, or young, what to you say? But this is no proof because, as Mr. Cooper asks: "Why has not some oologist found the eggs?" I suppose he would say Leaclr's and Wilson's petrels are the same because no oologist has ever found the eggs of the Wilson.

You also instance the Red-throated Loon in adult plumage; also the Grebe as never being found in your latitude. 'The old birls are with you just as much as the young. 'They go south as regular as wild geese but not in breeding plumage except in spring. I saw one Ped-throat killed in Loug Island Sound last A pril, with the throat most changed to red. All ornithologists, European and Ameriean, say the American and European rough-leg are one and the same bird. I have sent black hawk skins to the best ornithologist in London, who says they have nothing like it 
and the Rough-leg never has any such chauges. I have quite an exchange of different kinds of birds for examination with uy English frients. I can see no diflerence in the Rough-legged, Duck Ilawk, or Fish IIawk; the Gosliawk has different markings, but its form, size, ete., are the same; Mr. Audubon ealled them the same. He also ealled the Rough-legged and Black Hawk the same with the remark, that "the old bird grew very dark."

Now my informant says the older the bird is the lighter is its color. 'They liave the eggs of the Black Ifawk at the Smithsomian, said to be anthenticated and tiken by good collector's aud naturilists and figured in the Smithsonian Oology by Brewer. But that would not prove them diflerent as many birts breed in immature plumage; many of the hawks, eagrles, ducks, ete. So if it was the young it miglit do that. I am very sure from what information I can get it is not the old, as many of the ornithologists have thonght. Dr. Richardson found it breeding (the Black IIawk) on the Saskatchewan, but they are quite rare, while the common lough-leggel is quite plenty. 'The Labrador folks report the black Ilawk quite common, but one sent me was a young, very dirk Gyrfalcon and might not be the bird we are talking about at all.

Do not think I an writing all this to make you believe they are two, only to give you some information why they have been eonsidered distinct. I asked Prof. Baird a year or two ago and he would not commit himself. He was in tonbt about their being two, as I thought at the time. Cassin thinks they are two. 'The young of all hawks are very much the most uumerous. With the Marsh Hawk I get twenty young to one old, while the same is true of most Ilawks. Now if the Blaek bird is the immature one how does it lappen there are ten Rough-legged to one black, which I think is the ease all through the eastern states.

I have written in such a hurry I do not know as you will understind me. If you have any new ideas about this interesting subjeet I shouk like to have then. 'There have been Bohemian Chatterers or Winter Waxwings in my garden today. 'They are a very pretty bird. My son saw them but did not shoot them. I think I had better close up as I kuow you will be tired of this long scrawl. So good night.

Yours as ever,

Geo. A. Boardman. 
Millatown, 16 May, 1869.

Friend WOOD:

I have onlybeen home a few days and have been so busy I have had but little time to look after hirds or eggs. I find after my long absence everything right at my house. The mills are now sawing lumber so fast I find I shall be obliged to go west again this week to be gone a couple of weeks. I wrote my folks to be on the lookout fol eggs, as I wanted a Broad-wing's nest for you. On one of the hottest days, almost, you ever saw, an Indian came and said he had found the Broad-wing's nest, that he was going up river next day and I must go that day, or lose it. I was busy, the rain was a heavy one in which to ride five miles, then go into a swamp I did not know how far - it was almost too much for me. I would have sent the Indian back, but we have so many hawks I wanted to see the bird so we started. We were in a good covered earriage, had good rubbers and umbrellas. We rode as far as we could go with the horse and then started on foot. Found the tree in a thick swanp, after a loug walk and were as wet as drowned rats. 'The Indian started up the tree and away flew the hawk. It was a Broad-winged. The gun, however, would not go, so we lost the bird, and after all our trouble there was only one egg. I concluded to take it as I do not think I could ever find the place again, and an egg in the hand is as good as three in the woods. So I hope you may get it in good order and every time you see it, remember what a wetting we got for one hawk's egg. At any rate I shall not go egging again when it rains hard, if I can help it.

I don't think of any other eggs I have that you want and I may take this one along with me and send it by express from Boston or New York. Baird teld we he had sent you a lot of eggs. Did he send you some good ones? He is coming down this way again to spend his vacation with me with his wife and daughter. He has, you know, a soft place in his heart that runs to birds and eggs, but a softer one still that runs to old Indian shell heaps and mounds and I suppose he will be into them all the time he is here. I think I wrote you I did not see your friend Dr. Wilson. He is doing well and is mayor of Darien. I saw Allen quite a number of times in Florida, also young Mayuard and several other collectors. Yours very truly,

GEO. A. BOARDMAN. 


\title{
242 THE NATURALIST OF THE ST. CROIX
}

\author{
Caldais, Me., Aug. 25, 1869.
}

\section{DEAR DOCTOR:}

I received your Indian historical epistle about a week ago for which I am much obliged. I have read the history of those old Indian ehaps long ago but the dates are very interesting, as I had forgotten them. I hope that Prof. Baird may find all the places you mention with the relies all labeled and dated.

Prof. Baird and myself have been around having a pretty good time. He is now over to Grand Manau. I expect him back in a day or two. I started twice to go over with him but the fog and head winds detained us. I left him at Eastport. He got a chance over in the revenue boat and went over without me. I gave him good letters to my friends and hope he may find some good things. He will probably find the bones of the Great Auk, also bones of the Walrus, as they were said to inhabit this const a few hundred years ago. If he finds anything new or rare I will report when $I$ write you again.

I believe I wrote jou I had added two new birds to my list since he has been here, a Black Vulture and a Purple Gallinule. I think they must have followed the Professor up, although he says he never knew either of them taken about Washington. We have a little muddy lake about two miles from where I live where several kinds of grebes breed. They breed very late - some of the small ones. I was out with the Professor to try to get some chicks. I got two that I don't think were over two days old. 'They are very cunningly marked little things when so young and look very prettily mounted. I also got a young loon about the size of a teal. I think those elicks look very pretty in collections and I have quite a number of them. I must try to get more of the young grebes, but the larger ones are hard to shoot. 'The Hormed and Dab Chick are most common, while a few Red-necked breed. We found some deserted nests, but no eggs. They build a floating nest among the rushes. 'To get to the nest we have to carry a canoe some distance over a bad roal to the lake.

I go out shooting almost every night after tea and nost always get some ducks, pigeons or partridges. We had a nice dinner to-day of black dueks and pigeons. Snipe and woodcock are quite plenty, but $I$ have no $d o g$ to find them that is good for 
anything. When the I'rofessor returns we are to go to St. John, Prince Edward Island, IIalifax, ete, so he says. Our mills are doing but little now and I call get away very easily. Prinee Edward Island womld be a good place to eollect eggs in the spring as many uorthern hirds breed there that do not go across the gulf. My palper is about out and I must elose.

Yours very truly,

GEO. A. BOALHMAN.

Friend Woon:

Mirltown, Me., 17 May, 1872.

I received your letter today and an always glad to hear from you.

I have only been home from Florida a few days. 'The weather has been so backward I did not hurry much. Made quite a tary all the way north and saw most all the naturalist folks excepting Dr. W. Wood, who should have been seen, but it is a little out of the way, when you have a lot of women and extra baggage.

I lad a very nice pleasant winter at the south. I spent seven weeks on board a little steam yacht shooting, fishing, ete, all the time. We went to the very head waters of the St. Jolnns river to lake Washington. We weut above most of the settlements and a long way above where any hunters go. We found lots of birdbreeding places. One breeding place was nearly three miles long, composed of egrets, eranes, blue and white water turkeys, etc. I wish you had been with us, you would have had a nice time. We had a hard time to keep our birds away from the alligators and they took a good many. Sometimes we would shoot a bird with one barrel and the alligator with the other so as to get to the bird before it was lost. I shot over fifty of the large WhitePlumed Crane. We found ducks, turkey, deer, quail and snipe, quite abundant. I found on the Upper St. Johns many birds quite new to me, but got nothing very rare. I did not eollect but a few eggs as they most all got broken. The party consisted of tive. We made up quite a number of slins; some of the gents are having them mounted in New York and they are going into a mounted collection. I shot in two hours, one afternoon, nineteen White Cranes, two big Blue Cranes, one Wood Ibis, two White Ibis, one Swallow-tailed Hawk, one Gray Squirrel and several small birds; 


\section{THE NATURALIST OF THE ST. CROIX}

so you can see we had some good shooting. But the great shooting was at alligators; they were not spared.

I have not collected any eggs for a year or two as I have about all that are found here. I have nothing new of the bird kind except a White Red-tail, a very nice pure white albino without a dirty spot on him.

The season is very backward, no leaves on the trees yet but warblers have all got along, and $I$ shall go to collect a few if it is warm to-day. I made Baird a visit on the way up as usual. He is hard at work, will spend the summer down with us, or about Eastport. 'There are to be quite a lot of scientifics this way this summer and we hope to go among the Islands and have a good time.

Yours as ever,

\section{G. A. BoARDMAN.}

\section{DEAR DOCTOR:}

Milltown, 20 Aug., 1872.

I an glad to hear from you. I have to answer ny letters as soon as $I$ get them. I have so many if they are left over and filed away I might never see them again.

I have just returned from quite a cruise down east with Prof. Baird. We started with the ladies for St. John. Went from there to Digby, N. S., up the Annapolis valley to Windsor, then to Halifax, then to Pictou, and over to Prince Edward Island; back by way of Shediac to St. John, then up St. John river to Fredericton and thence back by rail home. We called to see all the bird and scientific folks. Had a nice company, very fine weather, and all enjoyed ourselves very much. I see by the papers the weather has been very hot west, when we were wearing overcoats down in the St. Lawrence and were comfortable. We found some very nice folks in Halifax and would like to ask you, doctor, how it is that most all the naturalists we found were doctors? We found Dr. Gilpin of Halifax very much interested in collections and paid us every attention. I had been over the route before and knew who to look after, so went to show the professor what a nice looking country there was down east in summer. You would be pleased to make the trip in hot weather. You would see many birds quite new to you for summer birds, and you would miss many of your old summer acquaintances. I hope you may soon have the railroad finished on your side of the river. 
I have never found the Pigeon IIawk's nest. I have no doubt it breeds, as I shoot it all summer and winter. It no doubt breeds in some thick trees not easily seen and besides, it is not a very common hawk with us. I was pleased with Allen's papers. I never knew of a sturgeon taking a hook; they are not common with us, on our river. I have not been doing much fishing since May when I went up salmon fishing and two of us eaught about sixty. I have been shooting considerably, before I went eastwoodeock, ducks, ete., but nothing very new for my collection. Did I write you I shot a Vireo Philadelphius in the spring? As soon as I get over my hurry shall try to go up river on a little fishing and shooting exeursion with the professor. Several of the egg collectors have been this way and over to Grand Manan. Do not think they found many new things. Young Herrick got some eagles' eggs; Mayuard and his friend ouly found some common things. I have no duplicate eagles' eggs, only one nest of Whitehead, and one nest of Golden Eagle; the egg of Horned Owl, and also Ilumming bird eggs I have had for a long time. I have collected very few this season. $\Lambda \mathrm{s}$ my collection is about full $\mathrm{I}$ have not looked much after them. IIoping to hear from you often,

BOARIMAN.

Washington, D. C., 1211 I St., Feby. 6, 1878.

\section{DEAR DOCTOR:}

I believe I have not written you for some time to let you know of our doings.

We left home for the South about Christmas but heard upon our arrival here that there was considerable sickness at Jacksonville, so we took rooms here and have found the weather so very mild and everything so very pleasant we have about coueluded to remain here for the winter, but if the weather gets too rough we may go along further south. We have spent so many winters in Florida the change for a winter north we think will be very agreeable.

I would write you how I spend most of my time but you will know that where there are so many nice libraries and so very many naturalist folks here we can have our time well occupied and there is something all the time to interest me. We go to the Capitol very often when any of the great guns are to make 


\section{THE NATURALIST OF THE ST. CROIX}

speeches. We heard your Mr. Eaton yesterday. IIe is quite a good speaker and took the right side of the question. 'This forenoon we go to visit the Treasury. 'There is a house full of down east people who board with us. Last evening they were at the President's reeption and had a nice time. I do some work at the Smithsonian for l'rof. Baird and spend considerable of my time over there. Don't you ever get down to Washington? Should be glad to see you here this winter.

I saw a paper from you in a new Springfield little work and am always glad to see your papers. It is very singular yon never get the Black Vulture as well as the Turkey Buzzard in your state or at your place. Since I have been collecting I have known of six being taken with ns, besides several about the Nova Seotia shore - very many wore than of the common Turkey Buzzard. I have the Black Robin I wrote you about at the Smithsonian, body black, wings and tail white.

Before I left home there were some of the Bohemian Chatterers about our gardens but I did not get any. Did not collect anything very new before I left although I got one little sparrow or Riehardson's Owl. I an writing in a hurly as the ladies are hurrying me to go out with them. Let me hear how you prosper. Hope you did not lose the money you wrote about as being endorser for a scamp. I have lost the same way, to a very large amount and have a law snit for more, that I may have to pay, but hope I may beat the rascals that swear to anything.

Sincerely yours,

Geo. A. BoARdMan.

Minneapolis, Minn., 23 South 13th St.. February 2, 1883. MY DEAR DOCTOR:

I have not written you for a long time, and think it about time I gave you some account of my doings.

I eame out west in September to visit my children, expecting to go to California in the winter, but my wife has not been well enough to try the passage. She is now much better but we are so comfortably settled with my laughter that we may not get away. One of my sons is with us, and two others live very near, so we have all our children but one son here in Minneapolis and the children are trying all ways to make us live out here with 
them. I think we are too old to ehange. All our associations are east and to live here we should have to learn the people over again which would be hard to do.

I have had some interest in looking up the new birds of this loeality. Many are common here that we seldom or never see, such as Evening Grosbeaks and Bohemian Chatterers. We see them about the streets feeding on the mountain ash berries and high bush cranber'ries. Last fall I went up to Dakota for a time. One of my sons has a large wheat farm there and had a very nice time. The whole country seemed full of wild geese and ducks. We did not get many P'rairie Chickens as we had no good dog. I saw great numbers of hawks; they were about in great numbers and varieties, Rough-legged very common. Some very dark ones - Red-tailed, Swaiuson's, Rough-legged and Broadwinged were most numerous. Black Vultures and Swallow-tailed hawks were common in northern Dakota. If I do not go to California I hope to go up again in April and see what comes along in the spring. I did considerable shooting last fall but mostly ducks and snipe. I did not get auy very rare birds for specimeus.

The winter has been fine but cold. I have been south so many winters I much prefer the orange groves to the snow banks of Maine or Minnesota.

'This is a very nice place for business. Everything goes with a rush - just the place for young folks. My sons like very much and they think they would hardly want to live east. The place has added forty thousand to its population since I was here three years ago and property has doubled in value. I think it a good place to invest. 'I'venty-five hundred buildings were put up last year at a cost of $\$ \$, 500,000$ and about the same in St. Paul. Every one is speculating in real estate and getting rich twice a week. I don't find much new in the way of natural listory and very few that take any interest in such things. It is nothing but business. I hope you have something new to write me about that you have found in your section. 'There were three Evening Grosbeaks just on the trees near the house and they always keep where you are not allowed to shoot them.

Sincerely yours,

Geo. A. Boardian. 


\section{THE NATURALIST OF THE ST. CROIX}

Calais, Maine, February 17, 1885.

Friend WoOd:

I was glad to hear from you after so long a time and was quite interested in your paper about Mr. Fitch being the first steamboat builder. I remember of reading in some of my old books something of the kind. It was in the reports of the Commissioner of Patents for the year 1859, with a picture of Fitch's steamboat. The account is from page 526 to 544 , but I suppose in your researehes you have seen all this. If you have not I should be glad to send you the book as it would be interesting to you. Poor Fitch had a hard time. He should have a good monument to be remembered by, as he was a wonderful man and Robert Fulton has always had the credit for steamboat invention which belonged to Mr. Fitch. About the same thing was done by Morse in telegraphy. Irof. Henry was the inventor much more than Prof. Morse but Morse got all the credit and the money.

I am glad you have not lost your interest in Natural History and hope some time we may meet and talk over matters. I often go to see the folks at Central Park Museum. 'They are very nice people and I think they have about the nicest eollection I see any where. I like it as well as the National Museum at Washington. 'There is also a very fine collection at Cambridge. I am so often west and south I see them all most every year. I have not seen so much of the Academy folks at Philadelphia since Cassin's death and many of the young folks I do not know. I ealled to see Mr. Krider. He is a nice old fellow and used to have a good collection of skins and eggs but now is too old to go to his oflice to do mucl. He has a son who does part of his bird work. I always find a nice set of fellows at the Smithsonian, those who have been in government employ in most all parts of the country and are good collectors. They usually all get in in winter except the Alaskan or Hudson Bay folks who usually remain up for several years.

Since I wrote you we have been having quite cold weather, snow now quite deep, but February has only about ten days more and in March we expect to have warm days once in a wbile. I like the orange groves much better than the snow banks and am beginning to wish I was in Florida or California where I could be out in the woods. 



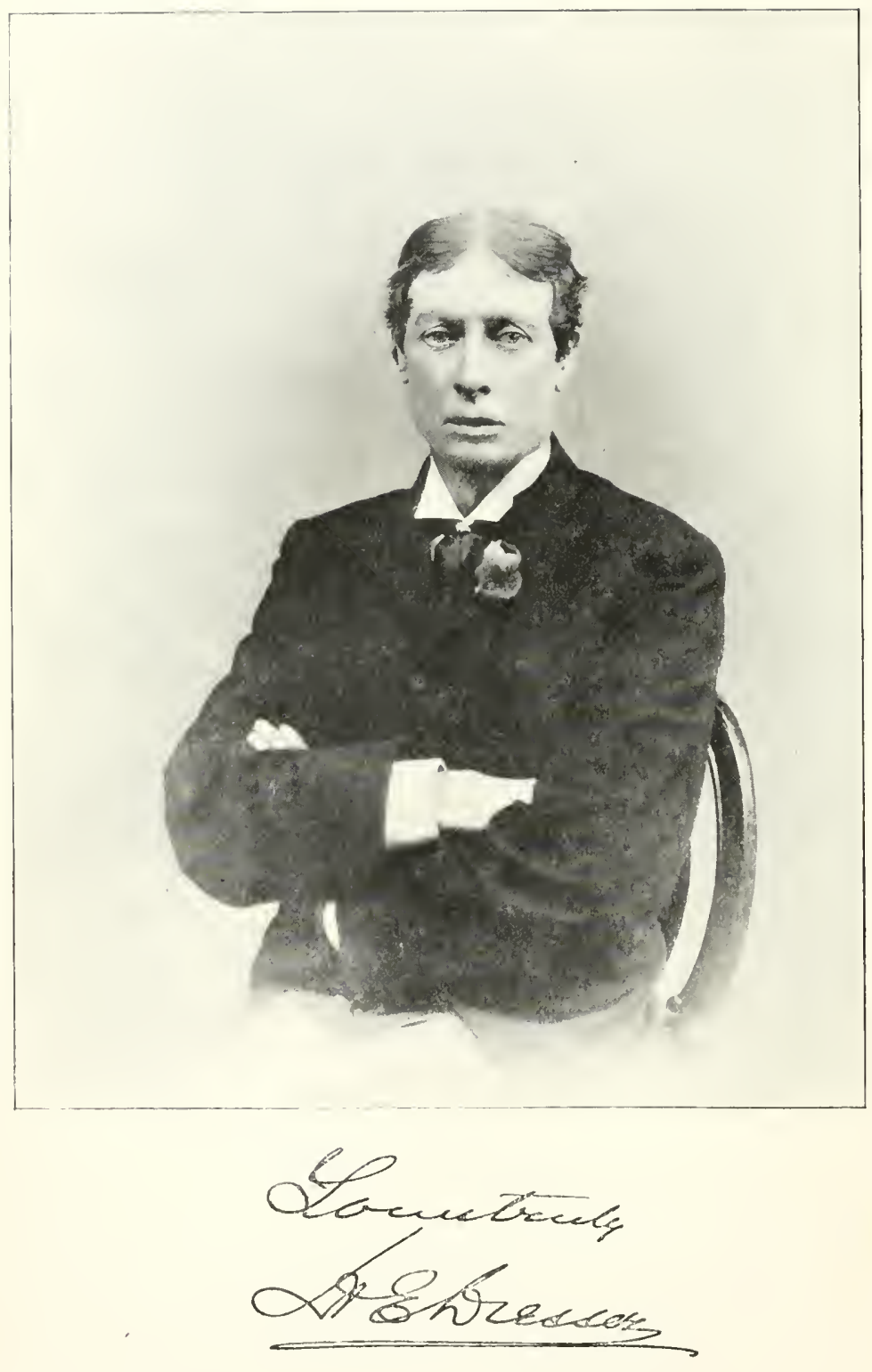


I have collected nothing of late but a few eommon gulls. All our Pine Grosbeaks have left to go south and I hardly see a woodpecker or chickadee about the trees.

sincerely yours,

Geo. A. Boardman.

Among the foreign ornithologists with whom Mr. Boardman corresponded for many years is Henry E. Dresser of London, England. Among the papers of Mr. Boardman have been preserved seventy-one letters from Mr. Dresser, the first bearing date of 1862 and the latest of 1874 . The period of greatest activity in this correspondence was during the years 1865 to 1867 . There have been examined fourteen letters written by Mr. Dresser to Mr. Boardman in 1865 ; fifteen in 1866, and fourteen in 1867. In answer to a request for letters of Mr. Boardman Mr. Dresser writes from London, October 24, 1902 : "I have hunted high and low for letters from Mr. Boardman that might be of use to you in your memoir but can find none or I would send them with pleasure." It is matter for regret that no letters from Mr. Boardman to Mr. Dresser have been obtained but from the few from Mr. Dresser which are given in this memoir it is easy to infer the nature of their correspondence and the subjects upon which they were writing.

Henry Ecles Dresser was brought up for the lumber business and after having been at school in Germany and then to the Swedish university at Upsala, where he 'sarned that language, he went to Finland to learn the 11'mber business. After acquiring every detail of the business he was sent out to the Lancaster mills at Musquash, near St. John, N. B. It was while at Musquash that he formed the acquaintance of Mr. Boardman. "As 


\section{THE NATURALIST OF THE ST. CROIX}

Mr. Boardman found," says Mr. Dresser in a letter of November 7, 1902, "that I was working at ornithology we became great friends and he helped me a great deal; for though I knew European birds well, it was then my first experience with American birds." After having had the management of the Lancaster mills for a year, during which time Mr. Dresser installed the new local manager as a change in their operation was necessary, he returned to London. While at Musquash he made two visits to Mr. Boardman. In 1864 and 1865 Mr. Dresser visited Texas and Mexico, studying the birds of southwestern America, since which time he has not been in this country. He has, however, traveled extensively in Russia, Sweden, Lapland, Greenland and in southern Europe. Mr. Dresser has a beautiful country house, Topclyffe Grange, at Farnborough, R. S. O., Kent, where he formerly resided and where Mr. A. J. Boardman, one of Mr. Boardman's sons, visited him a few years since. He now lives in London, however, where he is engaged in the steel trade, having changed from lumber to steel when he last moved to London - a fact which shows the change in the building trades during the last twenty-five years. In a recent letter Mr. Dresser writes : "In answer to your question I would say that I have no connection with our universities beyond that Prof. Newton of Cambridge is one of my oldest and best friends and we often work together. I am only an amateur ornithologist and, like the smith of Scott's Fair Maid of Perth, "I always fight for my own hand only and love my independence." Mr. Dresser's writings on ornithology have been very important and embrace the following : 
A IIistory of the Birds of Europe (ineluding all the species inhabiting the Western Palacaretic region). 8 vols. 4to. Iondon, 1871-81. Containing nearly 5,000 pages of letterpress aud 633 hand-colored plates by Joseph Wolf, J. G. Keulemans, and E. Neale.

A List of European Birds, including all speeies found in the Western Palaaretie region. 8vo. London, 1881.

A Monograph of the Meropida, or Family of the Bee-eaters. 1 vol. Small folio, cloth. Iondon, 1884-86. Containing 34 hand-colored plates by J. G. Keulemans.

A Monograph of the Coraciidse, or Family of the Rollers. 1 vol. Small folio, cloth. Farnborough, Kent, 1893. Containing 27 hand-colored plates by J. G. Keulemans.

Eversmann's Addenda ad Celeberrimi Pallasii Zoograpliam Rosso-Asiaticam. Aves, Fasc. I.-III. 8vo. Kasani, 1835-42. Facsimile reprint, edited by H. E. Dresser. London, 1876.

A supplement to the Birds of Europe. 1 vol. 1895.

In addition to the above works Mr. Dresser's lesser writings and papers on ornithology are scattered through several scientific periodicals and, as Secretary Langley of the Smithsonian Institution writes : "Are too numerous to designate by titles. Copies of all of them are in the library of the Institution. One of the most important of these is his monograph on The Birds of Texas published in The Ibis in 1865." Notwithstanding the fact that Mr. Dresser has written so much upon his favorite pursuit - which he has made a study since he was fourteen years of age - and is closely devoted to business, he is now writing a Manual of Palæarctic Birds, half of which is printed and the remainder going through the press. It will make a work of about one thousand pages and will include nearly 1300 species. It gives full particulars of range, habits, nest and eggs of the species. "After this work is completed," Mr. Dresser writes, "I hope 
to bring out a work on the Eggs of the Birds of Europe, as a companion work to the Birds of Europe." In the letter from Mr. Dresser from which extracts have already been made he says: "I have moved to London as my wife disliked the country; but I have kept the old place in Kent and hope some day to return there. Here I see all my naturalist friends and have just had Styan and Rechett, the explorers in China, and Selores the 'mighty hunter' in Africa spending the afternoon with me, and to-morrow Lesse, the Abyssinian explorer and naturalist, is coming to stay for a few days with me."

The more than seventy letters addressed to Mr. Boardman by Mr. Dresser during the ten years of their correspondence are most entertaining and important. They cover a wide range of subjects in bird life and all are worthy of publication. They are sufficient to make an entire volume which would be one of deep interest and of scientific value. 'The few printed show Mr. Dresser's charming style and his entertaining way of writing.

Letters from Henry E. Dresser, London, Eng., to Mr. Boardman

Iondon, the 10th June, 1865.

DEAR BOARDMAN :

I received your kind note of the 19th May and am delighted to see from it that the eggs of M. eucullatus have again been found by you. 'They are indeed a treasure for any collector as I don't know of any one who has thoroughly authentic specimens over here. I am still unable to find any vessel going to St. John or anywhere near you and don't want, if avoidable, to send to New York as the smashes might not be few sending that way. I look every week at our Lloyds list of ships leaving and don't see one 
alvertised for before late in July. I an however in the meanwhile pieking up good things here and there and have secured a magnificent egg of the Golden Eagle, not as generally seen, nearly white, but rielly elouded with reddish. It arrived with some Afriean eggs from Paris last week and I am promised another before long which I will also keep for you. I have some more Reeves, Gallinules, Coot and other egros asked for by you, all in your drawer waiting a chanee to pack them up and also another bird or two but these latter I get slower as I only want to get good mounted speeimens if possible, as I know your colleetion is all mounted. I will send the quails you ask for out of my T'exas duplieates. I have not many duplieates of anything, but whatever I have you may be sure you shall have willingly. I should have had more but the diffieulty in bringing back skins is so great. Could you ever get me any skins of the Plumed or Mountain Quail (O. pietus) and Gambel's Quail, as I have all but these two in my eollection and would like the lot complete. I think they would Inake a good ease well mounted with roek work and under a big shade. As for the glass topped boxes, I don't see any reason why I should not paek eggs in them, for even if there is duty on them it would be a trifle and if sent to St. John my brother could easily settle that. Anyhow, if I send via St. John I will try it on for I feel sure no fuss eould be made if one stated how many boxes there were and left one on the top as a sample.

I think if you onee began with this dodge you would never arrange your eggs otherwise. I have my eabinet arranged now and am pleased beyond my expectations.

I would keep your Hooded Merganser"s nest very close or you will have every person after you for the eggs. I will gladly give you anything you wish for in exchange for the eggs you ean spare, Golden Eagle, Ieeland Faleon or indeed anything I can proeure here and have in antieipation written everywhere I ean think of, asking for Golden Eagle's eggs - so must get some more.

I was eleeted a member of the British Ornithologists" Union (the same that give out The Ibis) last week and am busy preparing notes on the Ornithology of Texas for the press and will send you a eopy of it as it comes out if I ean get the editor to have some loose copies struck off, which I don't doubt of doing. I give it 


\section{THE NATURALIST OF THE ST. CROIX}

rather lengthily, as I have lots of notes taken during my stay there and I don't think wuch is known of the birds of those parts.

I have liad a lot of things sent me lately from different parts, but nothing that you would care for. How would it do if, when sending a box to you, I included some things for Krider, for I have not enough in large things to make it worth while to send direet? I am saving some rare Texas skins for him that he asked me for, Milvulus forficatus, Melanospeza Lincolnii, ete., ete. I must now close up as my time is growing short. I remain, Dear Boardman, Yours sincerely,

H. E. Dresser.

P. S. I had another long letter from Heermann last week.

London, 29 August, 1867.

\section{MY DEAR BOARDMAN :}

I received your kind letter of the Sth August all right by last mail and am much obliged by the information respeeting the expresses from Galveston. Unfortunately (as I see from a letter just received) my man in Texas did not get up to the place where the Swallow-tailed Hawk breeds, owing to continued rains and consequent floods and he has therefore not done much for me. IIe promises faithfully to be there earlier next season so I must live in hope of getting these eggs then. I have heard nothing of the Glentill yet but liave written to the owners to hear where slie is and arrange about getting the box sent on to me.

I know well who Dr. Leith Adams is that you write about and have seen some of his writings but don't know lim personally. He is a great friend of Dr. Bree, through whom I have heard of him. I don't know what sort of a collector he is but do not think he has ever done much and don"t think he knows much about American birds. I am glad I ean oblige Dr. Brewer in the way of stamps and will pick up all I ean for lim and can often pick up rare ones. Some of the English ones he asks for will be hard to get but others I will send. Whenever I write you I will enclose what $I$ can and he ean send you eggs in return for them if he likes. 'To me stamps have no value whaterer for the soft place in my head runs ouly on birds and eggs and I have often hard work to prevent my spending too much time over them. I should be very glad indeed to see his work on American Oology for such works 
always interest me very mueh. I have at last got your and Krider's boxes ofl and will let you know what arrangements I have made respecting freight before closing this up. I forgot to say that I sent a mounted bird of our Fish-lawk to compare with yours. Both this and the Cormorant were anongst those that grot slightly tomehed by moth during my journey to Mexico, but I found it so slight that I retained them and cured them with benzole and as I dicl not see any further sign I think you may trust them. I am vexed the King Eider slin was bad. I had just reeeived it from Greenland and thought it was all light. Some of those skins one gets one cannot trust very much.

The boxes have gone to the care of $\mathbf{W m}$. Thompson of St. John in the "Choiee," which vessel will sail to-morrow. Instead of having them with the eargo the eaptain said he himself would take charge of them and put them in his own eabin so that they should not be knocked about and that when they were safely delivered the receiver could pay him a trifle. I don't like doing things in so loose a manner but perhaps they will be better taken charge of thus. They are both addressed to you so will you kindly write to Mr. 'Thompson about them and get him to see to them, and as the freight would ordinarily be $7 \mathrm{~s}$. 6d. sterling each, if he gives the captain $15 \mathrm{~s}$. it would be fair. I don't want you to pay the expenses, so if you will write and tell me what the whole sum is (and you arrange with Mr. Thompson) I will gladly refund it to you. I addressed them to Mr. Thompson and gave the captain a letter to him to receive them as I see that the last things sent were sent to Mr. 'T. for you. Krider's box is marked J. K. and yours G. A. B. I have just received a nice long letter from Krider, from which I see that he is eolleeting pretty largely. I am rather anxions to see the latest Ameriean and particularly Mexican news. Did you see the particulars of the execution of General Vidauni? Poor fellow, I knew him well and have shared blankets with him on a journey through Texas. IIe was a very uice fellow although a regular Mexiean and we got to be great friends. I must write but a short letter this time as I have several letters to write for to-day's mail. Joe joins in kind regards. Believe me, Yours sincerely,

H. E. Dresser. 
London, 12 May, 1869.

\section{DEAR BOARDMAN:}

I wrote you on the 8 th inst. and as I aur writing a few lines to Dr. Brewer I enclose a note to you also, though on the whole there is but little to say.

By the way, I forgot to ask you when I wrote the other day if you would care for a couple of handsome eggs of the Pine Grosbeak from Lapland. They are still rare and very dear with us, but in purchasing a small collection from Lapland I got four of these eggs cheaper than I expected and shall be very glad to give you two if you will take them. They are in first rate condition. Did I tell you the other day that I had received (long ago) the eggs of Leache's Petrel all right and safe. 'They were left at the oflice without the bearer leaving word who had brought them. I wish Mr. Cullmen had ealled for I should have been very glad to have seen him at our house for your sake.

Our bird preservation bill has passed through Committee of the House of Lords and will soon be law. As soon as printed in regular form I will send you a copy of it as you will doubtless be interested in the matter.

By the way, what do you think of the rumors of war between us and your country? I myself don't think there is any fear of a rupture, as there are on both sides plenty of people who have good sense enough to work against it. There is no doubt we sympathized with the South (I rather more I think) but at the same time the United States in taunting us with it rather reminds me of the Pot ealling the Kettle black, for what did the very people who now sing out so loud do as regards the Fenians? I expect, however, the whole aftair is a mere outery of demagogues on your side and sensible people will not mind what they say.

Do you lnow of any one over here returning to your place, as I want to send you a water-colored painting by the new painter, Kieulemans, who now is making hiunself such a name, and I dare not send it over in the regular way for fear of damage. I don't at the present moment know of any one. With lind regards in which Joe joins, believe me,

$$
\text { Yours truly, }
$$

H. E. Dresser. 
I.ONDON, 2 Oetober, 1869.

DEAR IOARDMAN :

Thanks for your nice long letter of the 14th September' received this week. I an afraid I have not half as much to tell you in return as there is not much going on here just now.

I have had a first rate artist staying with me, a new man from Leyden called Keulemans. IIe can paint many birds I think quite equal to Wolf aud is a first rate ornithologist at the same time. I am trying to get him some of Elliot's work to do and an the more anxious to bring it about beeause I am fully convineed Elliot will be fully satisfied with his work, and he is a man who wants to push his way as a bird painter. I never saw any one but Wolf who could turn out such really artistie and true paintings of birds. He has done one painting of severat of the rarest of my Texan birds, amongst others of Dendroica chrysopareia, and he is not dear in his prices. If you see Elliot please put in a word for him as he is a most deserving man.

I should like to see the book they publislı at the Smithsonian on the clam beds. Can it be bought, aud at what price? I should like to buy many of the scientific publications in America if they are to be had and particularly those of the Smithsonian. I have tried to do so here but without success. How can I gret them?

You will have a nice trip in Florida this winter and I wish I could make it with you for if we were together I expect we should lo some big collecting. I will look after a mounted Greenland Falcon for you and can probably soon get one. I am glad you have some Petrel eggs for me as I am about out of them again and they are a good stoek for exchanging. Thanks for the information you give me about your game laws; we much need such a law here and it should be strietly enforeed for in au overpeopled conntry the birds should be protected. I see you have your birds all arranged now - what a lot you have! I have been getting ny American eggs all in order and eatalogued and will make you out a list of what I have when I have a spare evening to do so. I intend now to keep them apart from my European eggs and in fact to make quite a separate collection of them and shall have a large cabinet made on purpose. 


\section{THE NATURALIST OF THE ST. CROIX}

I litve Krider's box at last and opened it but find the eggs very badly blown and many broken. What a pity that he does not get decently prepared specimens for most of those he seuds are quite useless for exchanging aud moreover he gives no partieulars whatever with them.

I wish you could put me in correspondence with some one from whom I could get good blown specimens of eggs with particulars of loeality, ete. I would do a big exchanging trade and we should mutually benefit each other. 'There are so many eggs 1 want that are by no means rare in the United States and I can send lots of Greenland eggs in exchange. I get a few good eggs every now and again from Hepburn of San Franciseo, but of course only of westeru birds. What a mess they are in in Spain at present! I was expecting a lot of birds' eggs from there but I suppose under existing circumstances they will not turn up. People over there have something else to do just now besides attending to bilds" egas.

I see what you say about your son's wedding, and though I don't know him please ofler him my congratulations. 'There have been lots of weddings over here also lately, quite an epidemic amongst my own friends and I have seen three "bird" men, friends of mine, turned off' into matrimony during the last two months and two more intend to follow suit before the end of the year. I only hope their wives won't keep them from attending to ornithology.

Speaking about horns, I an trying to get some from Bombay where my second brother is fixed for some years to come at least. IIe lus a capital place, being now assistant engineer on the government harbor works there, and as the chmate agrees with him and he has prospect of quick promotion he has fixed to make his home out there. It is a pity he cannot skin birds for as he has quite a large body of men under him he might often get good things, the more so as he is taking soundings off the river and has the entire use of a government yacht.

Joe joins in kind regards and believe me,

Yours truly,

II. E. Diessier. 
DEAR BOARnMAN :

London, 28 August, 1868.

I have just returned from Norwich where I have been to attend the meeting of the British Association for the Advancement of Science and have had a regular treat, as fully three thousand people, English and foreigners, were there. I went down with Professor IInxley on the 18th and the next day the proceedings opened by a graud speech by the President, D. Ilooker, which touched chiefly on Darwin's theory aud the relations now existing between science and religion. 'The daily lectures aud discussions were carried on in some seven different section rooms, each devoted to one branch of science and ruled by a sectional committee under the general one. I was of course in section D, Zoology, and was on the committee. Our president was Berkeley, a botanist, but we had a good many bird papers. We generally met in the reeption room, a large sort of elub with all sorts of conveniences and at ten $\mathrm{A}$. M. the various committees met, and at eleven the rooms were open for papers to be read, etc., which lasted till three, after which we dined at some of the residents (as every one threw their houses open to friends) and in the eveuing were soirees and that sort of thing for members of the association. 'The pleasantest evening was the Lion dinner day when all the celebrities of section $D$ and all foreign naturalists at all well known and present meet together for a big spree and I can assure you that old men (and young) whose names are well known in the seientific world, such as IIuxley, Lyndall, Newton, Lubbock, Pengelly, Wallace, Gunther, etc., ete., were anything but the least noisy aud least inclined to join in the fun. I spent eight days there altogether and was very sorry to leave as it was a very pleasant way of getting knowledge.

'There were a lot of foreign professors there and amongst them old Nilsson, the veteran Swedish naturalist and Lorell, the Spiztbergen explorer with lots of Germans.

Most of our bird men were there, but both Salvin and Godman were unable to attend. However the "Ibis" brotherhood mustered pretty strong and made headquarters at the house of a brother "Ibis" resident there and the bird talk was, as you can imagine, rather strong in that quarter. 


\section{THE NATURALIST OF THE ST. CROIX}

I spent a good deal of time in the Geographical section where some excellent papers were read by celebrated travellers and the men sent out by Govermment to Abyssinia gave reports of the nature of the country, ete. Mr. Whymper, who has just returned from Greenland, read some very interesting papers he had written on that country, chiefly relating to natural history. I wish you had been there as it would have been the very thing to suit you.

I don"t know of much new to tell you in the way of natural history excepting that I lave a box of eggs over from northwest Greenland and if you want any eggs from there I shall be glad to supply you. I heard from Liverpool to-day that a box was there for me which I suppose to be the one from Krider; but they refuse to give it up unless I can produce endorsed bill of lading and it is now in a place where it will soon incur about its own value in expenses, so I am afraid it will turn out an expensive affair for me. Krider never told me low it was sent nor did he send bill of lading or anything by which I ean prove ownership so I am ifraid I shall be bothered to get it. I shall write and grumble at him for not being more business like. By the way, I should like very much to know if with you there is a close time for game or birds, viz., a time when it is quite illegal to lill them, such being the breeding season, and if such a law exists how it aets.

They are now killing such quantities of sea birds for plumes that people are thinking of having a elose time appointed by law and the British Association has appointed a committee (of which I am a member) to report on it. I slould be glad to see something done as there are such lots of gunners who destroy so many birds in the breeding season, and one plume dealer on the coast brags that he averages five hundred gulls per day through his hands, and this in the middle of the breeding season, so you can imagine the wholesale destruction of life amongst the deserted young birds, and it is ligh time that in a closely inhabited conntry like ours the birds should be somewhat protected, at least during the breeding season.

Hoping to hear from you again ere long, I remain Yours truly.

II. E. Dressir. 
LONION, 15 June, 1871.

DEAR BOARDMAN :

I am incleed an awful correspondent, but the fact is that I am so saddled with work that I am about as badly off ats Baird, anul I generally manage to pile a bit more on. I an glat to hear that you have hat so nice a time down south, and wish I eould have been there with you. You will have found plenty in the way of birds. Some day when I grow rich and able to rest on my oars (I don't see when it will be, by the way) I will take a trip) and see Florida. I quite long for it now for, wonld you believe it, we have lad fires nutil last week, June, and have not seen the sun for about a fortuight, and then it wiuked at us and evidently did not like the look of us and eonsequently looked elsewhere. I have seen the work on the Birds of California and don't like it as well as I expeeted. They seem not to have kept with the times, and speak of the eggs, etc., as unknown of lots of birds, the eggs of which are in the smithsonian. Besides they give such a little serap of information as to habits, etc., and it makes such a dry book. I hope more particulars will be given with the Birds of the United States. Elliot has been here for the past week ol two and I have seen him about half a dozen times. Ile is well and working hard at his book on pheasants. Ile left for Geneva yesterday and returns again in a month. Our book is getting along well, but does not pay its way yet, which we could, however, scarcely expect as we do it with seareely any margin - fifty pages of letterpress, quarto, and eight or nine large plates hand colored aud executed by a good artist, for 10s. Gd. requires a whole lot sold before it will pay. However, as matters go I hope we shall have enongh subscribers to make it pay by the end of the year. It keeps all my spare time fully employed. Elliot Coues has been writing to me lately and helping us but I can't get Baird to do anything though I would gladly pay well for any skins we require for the work.

By the way, if I send you a slight sketeh of a Surf Scoter's heal could you get any one to color it accurately from a fresh killed bird at a reasonable rate? 'There are many of these little details which one must look to. 
I shall be glad to ofler you a contributor's copy of our book, but the expense in having plates colored will not allow me to offer you one with plates. 'These contributors' copies are twenty which we had struek off on thinner paper without plates and loose in the covers, for people who assist us on the coutinent in sending notes from time to time and a couple of copies are still unappropriated. 'Three parts are ready and the rest ob:67 will be sent from time to time as they appear. 'The whole work will be of rather alarming size, say about 600 plates and about 3,500 pages of letterpress.

How can I send the copy to you? Shall I send it to the Smithsonian bookseller here, as the cost of book post would be awful. Do you know if $I$ could get any one to pick out for me all information as to the breeding of the aretic birds common to America and Europe? They have heaps of iuformation at Washington but Baird has not time to communicate it.

I myself am (I am glad to say) in splendid health, and since the loss of my hair have never known what a touch of illness is. I can't make it out at all for though I was not really ill it seems to have carried off all traces of the feeling of illness I used to have if I did not get out of town every week or two; but $I$ have not a single trace of hair from my head to my heels. It would puzzle a Comauche to "raise my hair" now, but I kinder calculate that he might eatch a 'l'artar if he tried, for all my bodily strength has returned to its fullest extcut.

I must, however, now close as I am hard up for time (a very general complaint with ne) and with very kind regards believe me Yours truly,

II. E. Dresser.

The correspondence between Mr. Boardman and Robert Ridgway of the Smithsonian Institution extended over a period of twenty-two years, beginning in 1871 and ending in 1893, six years after the death of Prof. Baird and eight before Mr. Boardman's own death.

Robert Ridgway was born at Mt. Carmel, Ill., July 2, 1850. From studies in the common school he early 
Sivallon tawted disawk!

Trifertits, Dredser

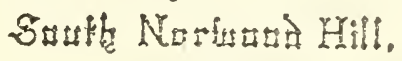

S.

donder the athayps

Seartizanowion

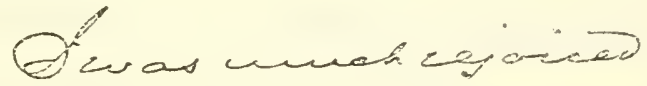

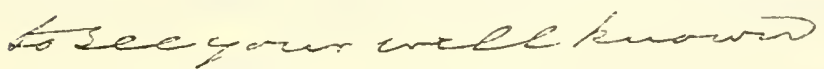

hamocurteing apam and ob

amglarto haor that's ond

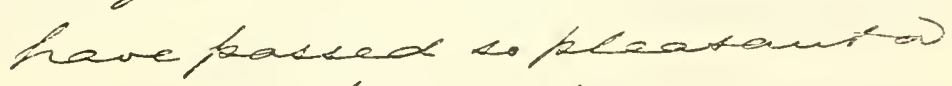

winter. O'wrsi flawede havo

been writh on bith an

forced tosteck towark if $Q$ b

doutruter do to have a mean

tive ofirin wh ocseased, for

owe unutputatiple ande

for hasotinnes. Oursih olcoud

de so defferenth to a elow

uyseffa zem, buthorradeas 
nowe, wakeng or watzo lasy

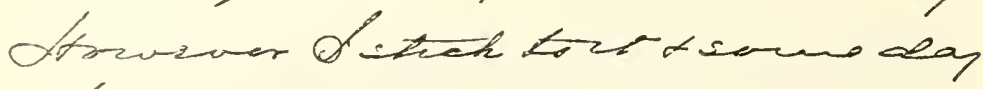

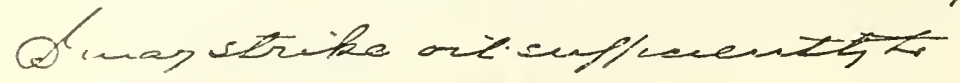
allow cuetorect awhele on my

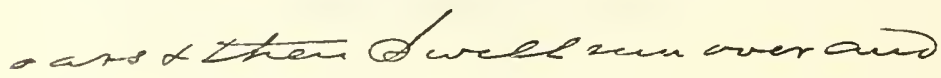
larkyou up. Bue thing in your bettas has nereveted no sreath $\alpha$ thal w what pon hand

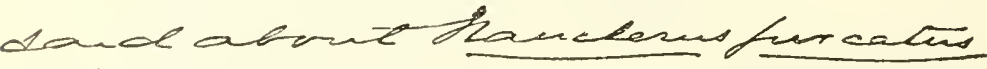

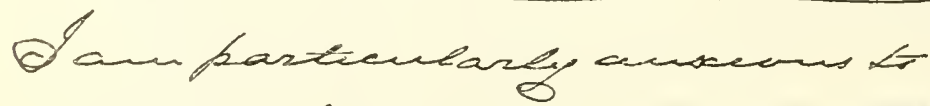
get ael fastecteans atout the no feateon opther biso a othave asescesiogegs ti, Iisure from bovederan untarest any ond dernum where you werdota-tathe a few noter ow theer breedeng havits and stel bezter coned the getethe young first en ther, first feathin aiv wishe a them to that we coved have a klate of thein. Thes have wever been 


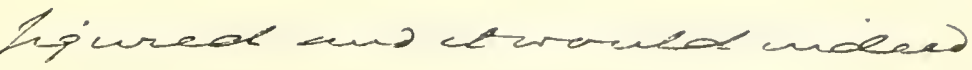
br a frather wi un capb to be able

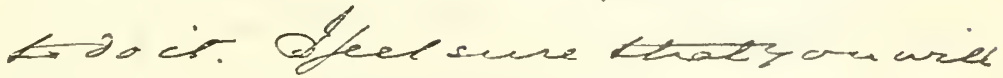
hegp we when olsee you that

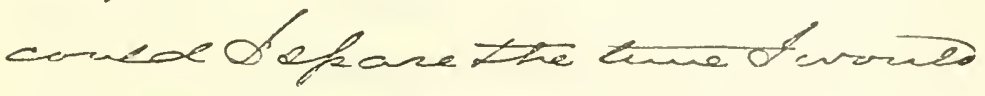

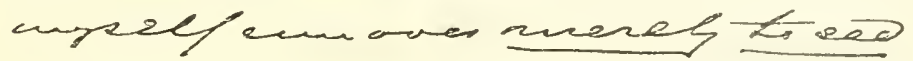

them bresdeng and getipgs and younyifusitsathess. Dam suite wricing to bay unhatever ed foir to aryoue who wiel habpes anderem des is as over book payp

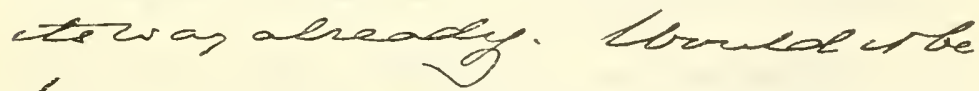
posuble to geta west taken an cendethe crhale vest una

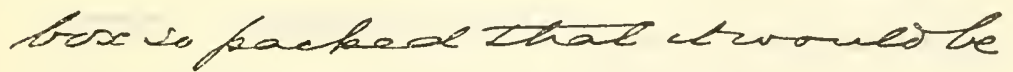

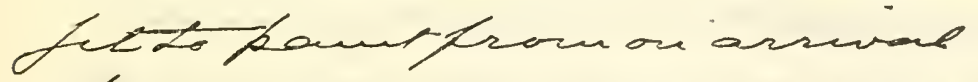

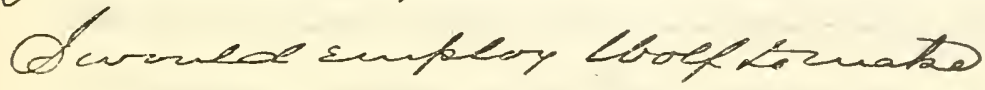
a handsone haintengof ch wive

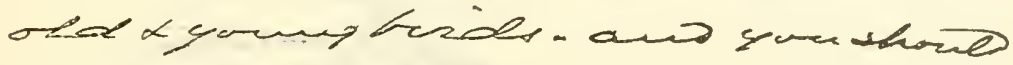


he ve the fivir cofts clinat off coloureobs kacf hmined. Pease ce help we in thin nolviel se ace Otcanto immortatare you as the fuctsure has suaces ustogeve

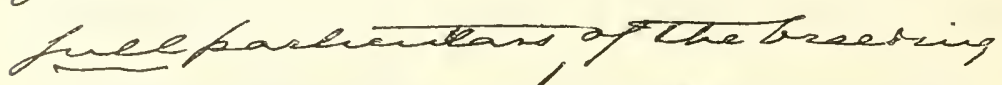

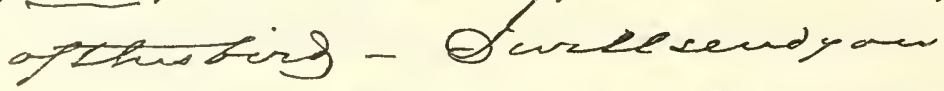
a cuecu batatof our harkeron the Whalleorn have havere our- bur we masease our letzer bress to lacgel that we are nececeary later. olurchee w what othermatcers you can heep us twiphease wite sevectsubw

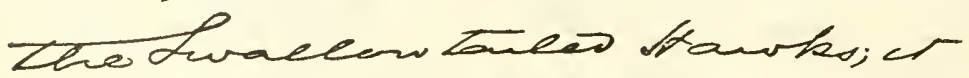

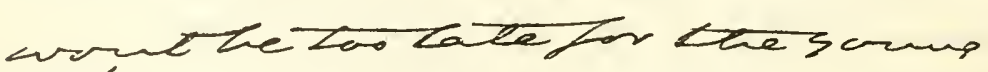

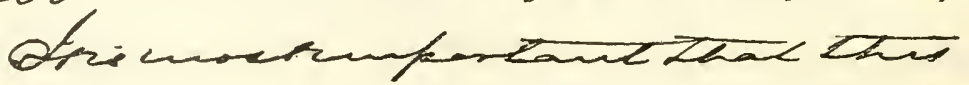

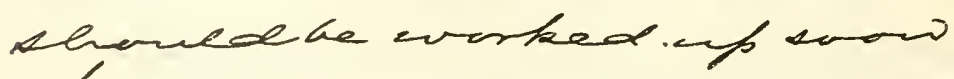

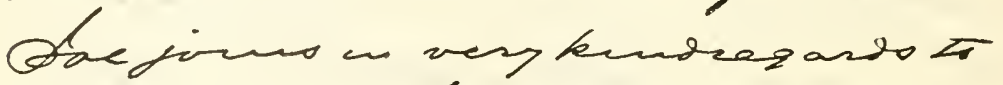

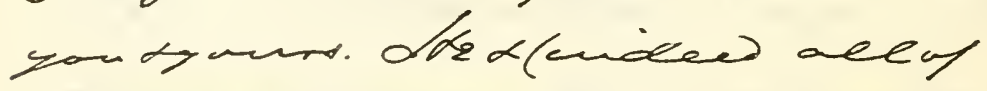
as) herfer weel. Hetere me oftopreator 
turned his attention to natural history and in 1867-69 was zoologist to the United States exploring expedition of the Fortieth Parallel of which the late Clarence King was chief. For the past twenty-three years or since his first appointment to the position in 1850, Mr. Ridgway lias been curator of the department of ornithology in the United States National Misenun of the Smithsonian Institution. He was one of the founders of the American Ornithologists Union and is an honorary nember of several foreign scientific societies, among them of the Zoological Society of London. His writings upon ornithological subjects have been numerous and important. With Prof. Baird and Dr. T. M. Brewer he was the author of that monumental work, A History of North American Birds, in five volumes. $\mathrm{He}$ is also sole atthor of A Manual of North Anerican Birds; A Nomenclature of Colors for Naturalists; The Ornithology of Illinois, in two volumes, together with more than three hundred and fifty scientific papers published either separately or in transactions and proceedings of learned societies, most of them upon subjects connected with bird life. A great work upon which he is now engaged is: The Birds of North and Middle America, the publication of which is being carried forward by the Smithsonian Institution, Washington, D. C. 'Two volumes, only, have appeared, 1901-1902, of 748 and 854 pages, respectively; while it is expected that eight volumes will be required to complete the work.

Mr. Ridgway writes Mr. Boardman, April 20, 1871, sending him a copy of his treatise on the Falconidæe and asking for the entire heads of each species of- owl that he 


\section{THE NATURALIST OF THE S'T. CROIX}

can secure and send him. He writes: "Any that you can procure would be a very valuable addition to my material for studying this family. The external structure of the ear appears to afford one of the most important characters among those available as a basis of classification and, of course, it is impossible to make any use of dried skins for the examination of this organ. Not recollecting just how complete was the list of desiderata that I gave you, I take the liberty to mention here, since you were so kind as to offer to obtain some of them for me-those which I desire." 'Then follows a list of fourteen New England and eight Florida species. To this request $\mathrm{Mr}$. Boardman made immediate response. May 13, 1874, he tells Mr. Ridgway of a man who found a bird that was new to him, exhansted on the gronnd. He described the Sooty Tern exactly, and says: "It is a new place for this bird. I have never seen it north of Florida." In this letter Mr. Boardman wants to be remembered to Henshaw and to know where he is going; to hear from Turner and what he got in Alaska; from Prof. Goode, Bean, Elliot, Milner and "all the folks."

August 10, 1874, Mr. Boardman writes, sending him a lark, "Very small and marked differently from any I have before seen ;" also a queerly marked warbler, "which we call a yellow or red poll but in queer plumage," about which he wants information. He adds: "I wish you conld come down here and see where lots of the warblers breed. We have several considered rare, as Baybreasted, Chestnut-sided, Black-throated Bluc, Goldencrested, etc." To this Mr. Ridgway replies : 
Wasington, D. C., August $19,1874$.

My Dear Mr. BoAliduan:

Your letter of the 10th inst received several days ago, was a pleasant surprise to me since it has not often been my good fortume to hear from you; I hope that you won't stop with this onr.

The birls eame in the same mail and atlorded me a great deal of pleasure - espeeially the young red-poll warbler (Dendroica palmarnm), which is the first of the plumage that I have seen; the stage has not yet been deseribed. Very likely you have the young of other warblers which are in the same "fix." 'The young of $D$. corulescens, $D$. virens, D. Jackburnire, D. castarea, $D$. maculosa and $D$. discolor, are also undescribed. In view of the fact that you may be able to supply them, I make a list of the other warblers of your section whose young are desiderata "non est come-at-able ;" they are the following: Helminthophaga chrysoptera, II. ruficapille, II. peregrina, Myiodioctes cancdensis, and the two speeies of Seiurus. Any of these which you can furnish will be gratefully leceived by the authors of the Ilistory of North American Birds.

The lark which you sent is an adult (probably female) of the desert race recognized as $E$. alpestris var. chrysoluma (Irugl.); it is the small, dark southern form which is found in Central America (as far south as Bogota, N. G.) and hreeds from southern Mexieo to California and Utah.

All of our wood-warblers are first clad in a plumage which they retain only a few weeks after being fully feathered! 'This plumage dillers totally from that usually ealled "young" and which is in reality the first assumption of the adult dress in fall: the young plumage proper is never resumed and lasts only while they are being fed by their parents. Apparently, all the species but $D$. pinus are streaked, above and below, in this plumage; at least $D$. striatn, D. palmarm, and D. coronata (the only ones yet colleeted to my knowledge) are. 'Ihus you see the importance of preserving specimens which you shoot just at this season for some of those which you mention as in "bat plumage " may be the very ones so mueh desired.

Mauy thanks for your kind invitation to visit your home; I assure you that I would glatly avail myself of it were it possible 
for me to get away. I know that I would find the woods of Maine a new field for me, and I have long lookel forwarl to the time when I shall have a chance to shoot birds there.

Hoping to hear from you soon, I remain Yours truly,

ROBERT RIDGWAY.

Acknowledging the receipt of this letter September 16, of the same year, Mr. Boardman says: "I go out a few hours most every day woodcock or snipe shooting but do not find anything rare. Among the young warblers I do not find any in nursing plumage - they are most all in good full plumage and all look like females. I hardly see a full plumaged male. I have had a nice visit from Dr. Brewer and wife since I wrote you. They were with us several days." Answering a letter from Mr. Boardman in which he says : "I suppose you and Mr. Brewster have returned from Illinois laden with spoils," Mr. Ridgway writes nunder date of J11ne 13, 1878 :

My trip was very successful in every respect. I think Mr. Brewster is also quite well satisfied. I got two lmulred and sixty-five fine skins and ahont one hundrerl and fifty nests and eggs besides live snakes and turtles and a tank full of alcoholic speeimens. Found the Duck IIawk breeding at Mount Camel, and got at one nest by cutting down the tree - a huge syeumore, 115 feet high (with nearly whole top broken off') and twenty-six feet in circumference, but, fortunately, a mere shell at the base, while the tree itself leaned a great deal, so that it required comparatively little ehopping to fell it. By me:surement the nest was found to have been eighty-nine feet from the ground. Ser"ral other nests were found in similar situitions, but none were accessible, while the trees were too large and solid to lay for cutting. In this ease got four full-fledged young and the female parent. 
Mr. Boardman says in a letter to Mr. Ridgway of July 1, 1878: "I was not surprised at what you say about the Duck Hawk breeding so far soutl for I lave for some years been of the opinion that the Duck Hawk and Pigeon Hawk breed far south and perhaps in Florida; for in my collecting I have found two forms of both those hawks, the size being very much smaller and the color darker. I have seen the northern as well as the southern birds in Florida. I have never seen but three Duck Hawks shot in Florida-two were much smaller than any I have collected north. But the difference in the Pigeon Hawk is greater. They are much darker than any I ever see this way and I have no doubt they are the southern breeding birds. Probably your Illinois Duck Hawks would be intermediate between the northern and the Florida specimens. I should like to see them. I have seven Duck Hawks in my collection, and all different from Florida birds. You were fortunate in getting such a haul from one nest. I have never heard, certainly, of their nesting so far south before."

Under date of December 25, 1878, Mr. Ridgway writes that Henshaw has returned but had a very poor field for work, while a letter from Mr. Turner dated Unalaska, November 10, complains of being in rather a poor field affording no novelties and few desirable species. He also wants Mr. Boardman's assistance in obtaining the clowny young (chicks) of any of the swimming birds as "acceptable material" for the work on Water Birds in which he was then engaged. Mr. Boardman's reply tells of his wish to assist him but says: "We do not have onefourth the swimming birds breed with us now that we did before the pickerel were put in our river, as they 
catch most of the young birds as they swim about with the old ones. A few years ago most every flock of ducks or grebes would have from seven to twelve young; now we hardly ever see more than from one to four: while many species of waders have left us entirely." Mr. Boardman adds; "I am sorry Henshaw was sent to so poor a field; lie is such a good collector I should like to have liin in a good place. As for Turner - I think a person going to Alaska should have something good in the way of specimens to interest him."

On September 9, 1879, Mr. Boardman writes of a strange migration of southern birds at Milltown that he has never known to visit there before. Among then were Black Skimmers - a large flock; Rhynchops Nigra and Laughing Gulls. Mr. Ridgway writes September 17, 1879: "The remarkable influx of southern birds to your New England shores is easy to understand. In the latter part of July and early part of August Henshaw and I visited Cobb's Island on the eastern shore of Virginia, where all these birds were breeding, and the cannonade we kept up there for over a week no doubt sent you the birds you rejoice over. So you should thank us for them. Brewster is down there now, and he reports birds of the kind you have with you as extremely scarce."

Writing to Mr. Ridgway June 12, 1881, Mr. Boardman says: "I have had nothing very rare collected for we here the past winter except an Ivory Gull, which was not in very good plumage; and a Black-necked Stilt, this spring. They very seldom come so far north; I never got but one before. I hope you had a good time out in Illinois and collected a lot of good things. Last 
fall I bought six lundred and forty acres of land near MIt. Carmel. I shall have to go out and see it. There may be some birds on it."

In 1882, when Mr. Boardnian was in Minneapolis, he wrote Mr. Ridgway on September 15: "'The little lawk, if a Broad-winged, is in very queer plumage. I have a good series of Broad-wings, yet nothing like it. If it had been taken in the fall I should have been less surprised; but taken in the spring when those small hawks are in full plumage, appeared strange. You can keep it as my collection is so much shut up and seen by so few people it would never be seen by many naturalists and I want it to be in the Smithsonian." That same month, writing from Fargo, he says: "The hawk I sent you was a male from Calais, about June 15. 'The men on my son's farm told me of an eagle's nest on a little hillock. The entire foundation was Buffalo ribs put in with sods so as to make a very pretty shaped nest. There were no other bones but ribs. Black Vultures are quite plenty here. I shot one to make sure." In a letter dated Minneapolis, February 26, 1883, Mr. Boardman writes : "I notice your surprise at my seeing Buzzard Black Vulture up in northern Dakota. It was a surprise to me, but I did not know but it was a place where they had been found and not learing from you did not write to Forest and Stream but will do so now. I notice in one of the late numbers Mr. Byrne of Crockett's Bluff doubts abont Buzzards being found in Maine, or so far north, as he has never, after living in Illinois half a century, ever seen one there. I have found them in Nova Scotia, at Grand Manan, in New Brtnswick and in Maine." 
In 1884, writing from Calais on December 1, Mr. Boardman sends a skin of Florida Pigeon Hawk and wants him to compare it with the pigeon hawks in the Smithsonian as "there is a very great difference in the bands of the tail from those of our northern birds." Again, January 8, 1885, he says: "One of my collecting friends in Minneapolis wrote me of going last spring up to Devil's Lake in Dakota and finding the large grebe-occidentalis - breeding there quite common. I have never heard of western grebe this side of the mountains and thought it must be a new thing. Write me if this large grebe has been found breeding so far east before." April 20, 1885, Mr. Boardman writes to Mr. Ridgway that "one of our Surf Ducks is a little different from those described in the books, but it may be common. Most of them have two white patches on the top of the head and back of the neck. We have them here with only one white patch, none on the top of the head. Do you have the Surf Duck with only one white patch?" On December 26, 1887, Mr. Boardman sends Mr. Ridgway from Calais, "the little hawk for you to see if there is any difference between it and the common Pigeon Hawk. 'The bands on the tail look to me different. I was sorry I could not make out the sex; but it was so sliot through the back I could not. It appeared, however, more like a female, althougl the dark color would indicate a male." Writing from Calais, November 10, 1870, Mr. Boardman says : "In looking over some of my old papers I see in Prof. Reinliardt's paper on the Birds of Greenland (1860), he speaks of a duck called Fuligula cristata, taken there by Mr. Walker at Godhaven during the stay of the ship Fox at that place in 1857. I write to ask if this is the 
same as Fuligula rufina. I have no names of European birds but thought it might be the sane duck as the one I sent the young of, got at the market in New York, which you thought the first one ever taken in North America. If it is the same the Greenland bird is ahead of it."

These several extracts are a good indication of Mr. Boardman's accurate habits of observation in the slight differences of the markings of birds, and his desire for exact statement of facts regarding species.

\section{Letters from Mr. Ridgway to Mr. Bourdman}

Wasinngton, D. C., June 23, 1881.

DEAR Mr. Boardian :

The box arrived to-day and I derived much pleasure from an iusprection of its contents, which were in good condition-the tail of the hawk a little mussed, however. 'The hawk proves to be what I suspected-the Short-tailed Buzzard-Butes brachyurus; and unless it should prove true (as has been held by some authors) that it is identical with the small black hawk called B. fuliguiosus, or B. cubanisi, a specimen of which was obtained last winter at Oyster Bay, Fla., is an addition to the fauna. Perhaps the other hawk you saw may be the same bird in another state of plumage. Will you lindly seud me particulars as to time and place of capture? I will have the owl put in good shape for Mrs. Baird. It is a fine specimen and will no doubt please her very much.

As soon as I can spare the time I will investigate the hawk question and let you know the result. With many thanks for sending the specimens, I am

Yours very sincerely,

Robert Ridgway.

Washington, March 5, 1883.

DEAR Mr. BOARDMan:

Four kind favor of the 26 th ult. reached me a day or two ago. It certainly is true that the Black Vulture is not common in 


\section{THE NATURALIST OF THE ST. CROIX}

Illinois. I have seen a few, but very few, near Mt. Carmel, where C. aur $a$ is not only extremely abundant, but also a regular winter resident! Can't you send us a few Evening Grosbeaks? Our series is very meagre-about half a dozen altogether, including good, bad, and indifterent. Of Bohehian Wax Wings we have plenty-that is, for our reserve series.

Nelson, at last accounts, had gone to southern New Mexico, but his regular post oftice address is Santa Fe, N. M. Iis health is somewhat improved, but his physician has ordered him to remain west for another year. We have not heard from 'Turner lately. Stejneger (I believe you met him at the Smithsoniau) has sent us some excellent things from the Commander Islands, several new speeies, including a fine large new Sea Eagle (Haliactus hypoleucus). We have now a number of good collectors in the field: Nutting in Nicaragua; Belding in Lower California, ete.; and Professor baird is going to send a man to McCloud River, California, and also another to Madagascar, as well as one to northern Mexico. Well, I lope this letter will not be as long reaching you as my last was, and hoping also to hear from you again soon, I am

Yours very truly,

RoberT RIDGWAY.

Dear Mr. boarduian:

WasiIngton, Deeember 4, 18s.1.

The Pigeon Ilawk was received this morning and I have just concluded a careful examiuation and comparison of it with our collection. The speeimens with which it was compared are from West Indies (ineluding Bahamas), Long Island, District of Columbia, IIdson's Bay 'Terr., Alaska, Califoruia, Oregon, Mexico, and Nicaragua-a pretty good series altogether. I am sor'y that we have no Florida examples with which to compare it, for your bird is certaiuly different from all of ours in the very datk coloration of the lower parts, restricted white markings on the imner webs of the primaries, and very broad subterminal black band on the tail. In the second feature a specimen from Santa Clara, California, is similar; but in the other characters nentioned your specimen is unique. Still, while it may be that resident Florida birds of this speeies may be like yours, I should 
Ealais thame Mor 25_-1885

Dear Pidgray

hy Ahiss o ginshy Alosira Pejeon Larrte Colunikería Lovk very bifferent from on thaire bins Altherigh Ofind the norchem bis Aorre tivies dom there.

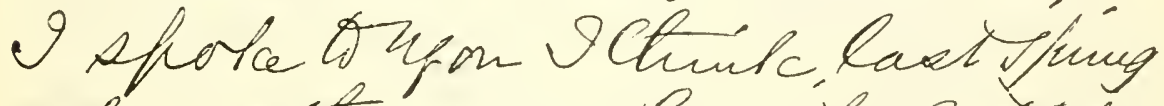
about then and have for fo thint Yon Saí, Have you auy firel Munuagskales Prom Bitorion? If to do you hotfind the dark band on the tail very huch Shor, and the birs sualler and darker Sefhot mustsentyon mine Flook at,

$\theta$

bohoteskectosecyon Chis 
this linter ao hurs Maardmen has hlaned Sronain at houe the are to Confortable here thindc ne shall try a Praine Brister lut the mifrative Inoturet is bo Grong he hay iuate a Start Rale in the murta aud get as far ao onshingtion of us farther. $\checkmark$ have been anay Or mauy Binters Orant osce if Caninot anfive mu hiutio biss, hothing erery

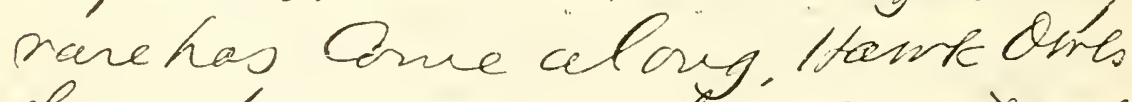
have been very abiusant, als BanedOrlo, have tein ho Saomy owls, our viecti have Pine Gros beaks nut tome Cross bill, Last fall yor the fínet hive

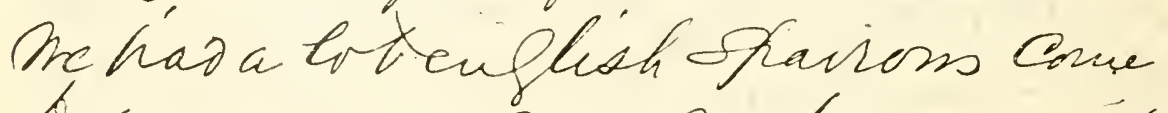
Slec us and buor one have quite a Gord Anply, Wita bscectien aborit un the muter he o hophe they may hotorive assay ous 
Aong ant other Rianoms that inees in the Inubory, Mrchave has a very hils face hery litte Pee and only a little firor Once, int the Sirke aud hord-ecok have aceleft. Hofre Anne Seator you may-gthere aud have a ohoot ariobee ku husenn,

Cerite

me that you get o hear from Hormer, aloo urile me shat

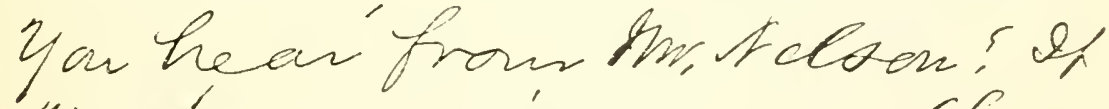
you have recieved any Ching ventrare or Shanfe in hay optirs this Acaxom.

There mas a Labrair falcen Shot hean here atew heck ago bit I conlo hot fut th wile he a goos longletter abowithe hashinftow , ales Exfucitir Cuec has a hieo hivit anay hiughegario tore cho falts finceraly yous Ga Doaronaw 

Lesitate to describe a new race on the strength of the one specimen. I would say, however, that should the lliflerences mentioned prove constant they would be suflicient to warant the separation of the Florida bird.

Very truly yours,

ROLELT RIDGWAY, Curator, Dept. IBirds.

P. S.-1 will keep the speeimen for a few days, or until I can find time to prepare some notes on it.

R. R.

DEAR MR. BOARDMAN :

WASHINGTON, Jin. 23, 1885.

I have been so busy since my return from New York that this is my first olportunity of answering your letter of the sth inst. 'The Western Grehe (I'odiceps occidentalis) breeds very abundant at Shoal Ialke, Manitobal, from whence we have numelous ergs. In fict, it lreeds throughout the western country in suitable localities, quite to the lacific coast and east to the easteru border of the Great Plans. Captain Bendire is stationed at Fort Custer, Montana, and is thoroughly disgusted with the place as a locality for collecting. Zeledon is here, and sends you his best regards. IIenshaw has returned, bringing with him about eight huudred birds, anong them two fine adult ('alifornia Condors, the largest weighing twenty-three pounds and spreading over nine feet. 'Turner is busy writing up his notes. Ile got nothing new except the nest and eggs of Pine Grosbeak. One curiosity which he got in the way of nest and eggs was au old Robin's nest in which a Red-poll hiul bujlt its nest and in which a Whiteerowned sparrow laid its eggs: IIe found the nest himself, so there ean be no "trick" about it.

Very truly yours,

Robert língway.

\section{Letters from Mr. Boardman to Mr. Ridgway}

JaCksonville, Fli., Dec. 24, 1880.

DEAR RHBGAY:

I hatve just arrived here and find your letter of December 16. I left home nearly five weeks ago and have been all the time on 


\section{THE NA'TURALIS'T OF 'THE ST. CROIX}

the way down. I am sorry I did not get your letter before I left, and an now afraid I cannot tell you any thing that will be very satisfactory about the duck.

I was in at Wallace's bird shop and he had just mounterl the duck. He asked me if I knew what it was and I could not tell lim, but got the bird to compare with my specimens, yet could not make it ont, and sent it to you, and I believe it was thought to be some cross. I think Wallace said he got it from the market.

If we had known it to have been a strange bird at the time we conkl have followed it, but Mr. Wallace only cares to sell birds, and the time has been so long he miglit not remember about it, for about the sane time I sent him a female Labrador Dnck to mount for your collectiou. When I went for the bird some one liad got it away from him or he had sold it and did not appear to know what had become of the bird. So if this is a new bird to the United States I should not eare to say too much about it upon the memory of Mr. Wallace. The bird appeared to have been just mounted and set with a lot of whistlers and mergausers and common madket birds. IIad I thought it to have been such a stranger would certainly, at the time, have got all its history. I liave almost forgotten what the duck looked like, and the full plumaged bird I thiuk I never saw. I think the bird latd some kind of a ring about its neck, something as a young plumaged Labrador Duek might have, but its bill was nothing like that of the Labrador Duck.

I intended to have made you a call when in Washington but was only there a short time, and did not go to the Smithsonian. I am expeeting to make you a good eall in the spring when we return, and hope you may have the new building partly in order. I see by the paper Mr. Ingersoll of the Fish Commission arrived here to-day. If you think of anything I can do for you here let me know and I will be on the lookout. With kind regards to all the folks and wishing you the compliments of the season, Yours very truly,

Geo. A. Boaruman. 
Misxeapols, Minn., June 4, 1886.

Fritexd litugway:

I latve not written you for a loug time and now have not much that is new to write about. We are having a very nice time here and see so many birds that are rare with us and many we never see, I quite enjoy a spring in the west; but in my shooting I get nothing new. I hope to get some chicks shortly and an try ing to get you a Krider"s IIawk if possible. I write at this time to say that a friend of mine in Comecticut says he has just had sent to him a very odul looking warbler, and writes me to ask about it. He says it is just like the Blue-winged yellow warbler except the black line that runs through the eye is lirger and runs further back on the lead. 'Then there is a clear black triangular pateh on the throat reaching well down on the breast. As 1 am not very much acquinted with this warbler (it does not come with us) please write me if it is anything more than some abnormal plumage of the birl which it so elosely resembles. If so I will write him to send it to you. I am going up to Wimnipeg and shall be back in a few days.

sincerely yours,

GEO. A. BOARDMAN.

Daniel G. Elliot, who was formerly superintendent of the Central Park, New York, was a personal friend and correspondent of Mr. Boardman, their correspondence extending over several years. Several of Mr. Elliot's letters appear among Mr. Boardman's papers, although none of Mr. Boardman's lave been preserved, Mr. Elliot writing August 15, 1902, that his mass of letters from correspondents had become so cumbersome that with few exceptions they were destroyed. On Mr. Boardman's visits to New York he rarely missed an opportunity of going to Central Park, examining their collections and enjoying calls upon their scientific workers.

Daniel Girand Elliot was born in New York, March 7,1835 , and is now curator of zoology, Field Columbian 
Museum, Chicago, Ill. Mr. Elliot has traveled extensively in this country and in Europe, Africa, Palestine, Asia Minor, Canada and Sonth America. He lias published much relating to zoology, his scientific papers and memoirs embracing more than one hundred separate works, the more important having been: North American Slore Birds; Gallinaceous Game Birds of North America; Birds of North America; Wild Fowl of the United States and British Possessions, together with several monographs in imperial folio, with hand-colored plates, on various families of birds as Grouse, Pheasants, Thrushes, Hornbills and Birds of Passage. Mr. Elliot is a fellow of the Royal Society of Edinburgh and has received many decorations from foreign govermments for his work in ornithology.

On October 23, 1862, Mr. Elliot writes: "I have procured for you lately a male Ruddy Duck in fine summer plumage. It is a skin, which I believe you prefer to having it mounted. I am just now putting the finishing touches to my work on 'The Pittas and shall be glad to get it out of the way that I may have more time for the Grouse." Mr. Boardman sent Mr. Elliot a copy of his list of birds of the St. Croix and in acknowledging it under date of December 4, 1862, he says :

I am obliged for the list of birds of your section which you sent me. Such contributions to our science are always very inportant, as I consider that at some future time the geographical distribution and migrations of birds will be subjects of most serious consideration by ornithologists, and therefore any light that one may be able to throw upon them will always be valuable for future reference.

I an glad to see you liave obtained the banded Three-toed Woodpecker. I was satisfied myself that it visited you, and 
recollect once asking you whether you had ever obtained it. I an satisfied you will get more. It is a dillicult hirl fo goet here, and I do not know of any one obtaining it in this state, althongh the other common species is sometimes met with in the nodthern wonds.

Writing under date of March 6, 1863, Mr. Filliot says : "Mr. Krider is here and went over my collection last evening. He found a good many desirable birds, but also some of the commonest wanting. That is always the way, we try so hard to get the rare ones that we overlook those that fly before our eyes every day. Can you tell me if the Spruce Grouse become blacker upon the breast (I speak of the males) as they increase in age? It appears to me that such is the case, but I would like to have the opinion of one who has observed them in their accustomed hannts."

On August 13, 1863, Mr. Elliot received from Mr. Boardman a young Spruce Grouse with other skins, and sending his thanks says: "I was, as you may suppose, delighted to see the chick and I would congratulate you upon your success in making up the skins for I think they are admirably done. I shall proceed immediately to make a drawing of the Spruce Grouse and hope when you cone to New York in the fall to be able to show you the plate." In this same letter Mr. Iilliot continues: "I notice your list of European Grouse, etc. I should like to see your Lagopus Alpina in full summer plumage. Can you be sure of the locality from whence they come? It appears to me from my researches so far, that there is no good species of that name, but it is only our L. Albus. Perhaps your specimens might throw some light on the subject, particularly if they are European. All the other species you mentioned I have." 


\section{THE NATURALIST OF THE ST. CROIX}

In describing Lagopus albus (Gm.), And., Cones edition of Stearnes' New England Bird Life, II., 145, says: "Mr. G. A. Boardman, Calais, Maine, to whom we wrote for information, assures us that he has been unable to satisfy himself that the Ptarmigan has ever been known to occur in New Eingland. With this explanation, which we trust will not leave us liable to the charge of improperly augmenting our list of New Englang birds and calling special attention to the insufficiency of the accredited records, we introduce the species hypothetically."

When writing upon the Duck Hawk in 1866, Mr. Eilliot writes Mr. Boardman May 24 of that year: "I wish to obtain some reliable facts in regard to its mode of nesting. Have you ever observed its nest placed in trees or does it always have them on some cliff? I believe you have taken the eggs and can give me the information I require."

In September, 1866, Mr. Elliot, with a party of friends including Mr. Newbold, a brother-in-law of Mr. Geo. N. Lawrence and Mr. W. J. Hays, came down to Nova Scotia on a shooting expedition for moose at which time he had hoped to visit Mr. Boardman at Calais. But the party went direct to Halifax from Boston by steamer, returning the same way, so that Mr. Ellliot never saw Mr. Boardman's collection. Mr. Boardman nuade all the arrangements for his friend on this trip, and in a letter of October 8 Mr. Elliot writes : "We have been most kindly received by both Mr. Whitney and Mr. McFarlane and everything was done to make us comfortable. I feel that we are much indebted to you for your assistice in making our trip pleasant and successful. We had very 
good sport, having killed seven moose, a caribou and a bear - a fair variety for a couple of weeks."

\section{Letters from D. G. Elliot to Mr. Boardman}

Orster BAY, 4th Aug., 1866.

MY DEAR SIR:

Your favol of 31st July is reeeived and I am much obliged for the trouble thit you are taking for me. Will you tell me whether at either of the places you mentioned we are likely to have any fishing, and if we had better bring rods. I shall probably be accompanied by two friends, Mr. Newbold, a brother-in-law of $\mathrm{Ml}$. Lawrence whom you know, and W. J. Ilays, the artist. We would like to know the best time to start and the route, and also any hiuts abont the requisite amount of greenbacks to bring. Do they pass in Nova Seotia? Can you give me any aceount of the habits, nesting, ete., of the Goshawk and Broad-winged llawk? I should like very much to meet you and have a talk about birds, when neither of us would be in a hurry, which unfortunately has generally been the ease in the eity. I im somewhat surprised about what you say of the change in plumage of the Black Guillemot. I have obtained them in the Orkuey Islauds in the black phumage, also in change and pure white, and they all seemed to be old birds, and I have never heard of the aduits having becu obtained jet black during the winter. If it is always the ease in your vicinity it is eertainly well worthy of heing recorled. IJoping to hear from you again shortly and seeing you at no distaut time, believe me

$$
\text { Yours very truly, }
$$

D. G. Elitot.

P.S. Will it be advisable to bring any kind of povisions for the woods? I always take a box of kuick-knacks along when I go after deer in the north of this state.

$$
\text { Orster Bay, I. I., 17th Aug., } 1866 .
$$

\section{MY DEAR BOARDMAN :}

Yours of the 9th inst. is at hand. I should like to have gone with you on your exeursion after the ducks, ete., and hope you were suceessful. Can you not manage to get a speeimen for me 
of Bonaparte's Gull with the black head ; it does not often get down as fir as our latitude, in summer plumage. When you write me when to go after moose, please to give me the route which I must take, and the time for me to start. I am going on Monday to shoot snipe on Squaw Beach, New Jersey, to be alsent ahont a week. Do you have any tlight of these Bay Snipe near you? I should think they wonld come that way. I do not think anything I should carry on my woods trip would be subject to duty. 'They will consist prineipally of eatables and drinkables, for my experience tells me it is always advisable to have some creature comforts along on such expeditions. I am now writing besicles my large work on the Birds of North America, a smaller popular one, to be included probably in about three volumes, and I am going to try and get Wolf to illustrate it with wood-cuts. I include all the speeies known to inhabit North Ameriea with an account of their habits, nesting, ete., and hope to make it useful and entertaining to all my comtrymen. 'l'he volmmes will not be any larger than Audubon's small work, easy to earry and handle. So any account which you can give of our birds, anecdotes, etc., will be very useful to me. IIoping to hear from you soon, believe me

$$
\text { Yours very truly, }
$$

D. G. Elliot.

MY Dear SIR:

New York, ]st Nov., 1866.

Your favor of the I3th was duly reeeived but as I have been away from town I have heen prevented from replying. I reached home safely after a rapid and pleasant rum. Baird has been in the eity, ealled upon me, but unfortunately I was not at home so missed him. I also did not have time to stop in Boston so lost the Cinereous Owl. I hope you may get it some time when you come throngh and will conclude to dispose of it to me. My reeollections of the moose hunt are very pleasant and I feel much inclined to try it again another fall. Your moose horns are very tine and must make a good show. I should like to know what the other set you mention measures. A black red squirrel is certainly a euriosity to say the least of it. I would like to see one. 'I'he White-headed Eagle doubtless nests on clifls at times, but I 



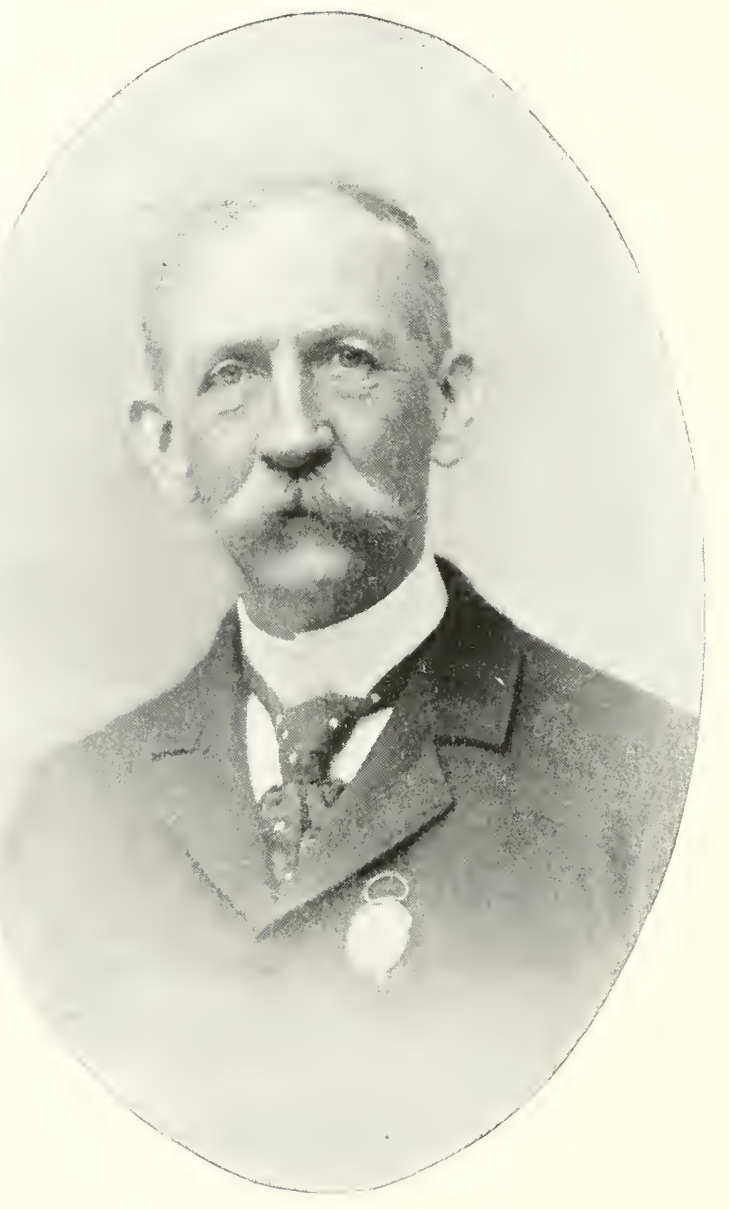

CHARLES HALLOCK

Foumler and Fint Editor of Fonest and stream 
should julge it would only be when there were no suitalle trees for the purpose auyluere in the vicinity. lions, like man, will anapt themselves to ciremetaners, although at times they may be olniged to act contrary to their nature. I have been thinking a goof deal about the Guillemot. It would be a fact well wortl ascertaining, if inteel it is a fact, that only the young change to white, or rather that the white plumage is an indication of immaturity, and the black the livery of only the alult birk. I know no person in a better position to determine the question than yourself who have them ahout you so much of the time. Your remarks about naturalists colying from each other are perfectly correct, and it is from this bad habit that so many erros's have been promulgated. I shall pndeavor in my work to be as indepentent as possible. I am going to-moluow into the conutry to shoot ruail, and shall try to have a shot at the ducks hefore long. 'They are getting to be plenty now on the coast; the cold weather at the north is hriving them lown here.

Let me hear from you at your leisure.

Yours very truly,

D. G. ELLIOT.

Charles Hallock is a native of New York city where he was born March 13, 1834. Previous to his establishment of Forest and Stream, the leading sportsmen's and naturalists' newspaper in this country, in 1873, Mr. Hallock had been at times editor of serreral leading jonrnals in this conntry, Bermuda and New Brunswick. Since 1860 he has done mucl collecting and ficld work in zoology for the Smithsonian Institution. He is an authority upon ornithology, is the autlior of many treatises on sporting and natural history subjects, has traveled extensively and had charge of special exhibits at some of the great expositions. 


\title{
282 THE: NATURALIST OF THE ST. CROIX
}

\section{Letters From Mr. Boardman to Charles Hallock}

\author{
Caldis, Maine, March 5, 1899.
}

DEAR IIAILOOCK :

I received your cart, atso a copy of 'The Osprey some days ago. I hatd engaged the photograph man to take my pretty pieture for yon, but npon the day it stormed, and I did not go, and my daughter said she must go with me, I suppose to fix me, so 1 might look young as you used to see me. My danghter has been sick with grippe ever since, but I hope to be able to send along the photograph soon.

The Osprey paper is quite a good thing; I have taken it ever since it was started in California under another name. Cones used to write some good things for it and now is head manager. Please aceept my thanks for your compliments in the last Forest and Stream.

'There was a paper of a week or two before by Mr. $\Lambda$. E. Brown of New York asking for correspondence abont young bears and I wrote my experience with them to Forest and Strean. 'Tliey are a queer lot.

At Lake Jessup, in Florida, I made the acquaintance of Capt. Brock, a great hunter, who told me of bears in Florida as large as any north, but the slins I used to see were all of a small breed of hesurs. I wrote Prof. Baird ahout the large bears, as I was told by Mr. lirock, and he wanted a skin. Brock also told me of wolves in Florida as black as any bear and also but rarely a black Iynx rufus. I got good skins of the hlack wolf, and a poor skin of a hlack Lynx rufus, but of good color, only the feet were ent off. I sent them to the Smithsonian for their skin collection. From my sonthern friends I learn that the cold snap destroyed many hirls even in Middle Florita, besides every flower and most every green leaf. Here we have had quite a fine winter, not as much snow as usual. 'The great hlizzard did not get up to us. We liad ruite a gale and about six inches of suow, but the weather was not as coll as in Washington, D. C. There have been only nine days this winter when the steanboats conld not get up to the uperer part of the aity to deliver Boston freight. 'The sleiglling now is abont gome.

sincerely yours.

Geo. A. Boaruman. 
MY DEAR IIALLOCK:

Calais, Aug. 11, 1899.

I received your note a few days since and notice what you say ahont remaining orer at bennysille for the remainder of the season. I know Mr. Allen leeps a better place than you conll find here, and Dennysuille is a good place, only it is ton far lrom Calais, as we "hirks of a feather" like to be together.

In regard to the black hawk which you see in North Carolina, I would say I only know of one large black hawk (not steel blue) that we eall the liough-legged Arehihuteo (lagopus sanctjohamnis) - if I have spelled it right. We have it here rarely, a kint of brownish black, and I have seen a few very black and think this must be the hawk you see. It is a sluggrish flyer ahout like a Red-tail or Marsh llawk. I don't know how far sonth they go but they used to be common down alont the Delaware, and about the best specimen I ever saw was at the Acallemy of Seience at Philadelphi:. I have several in my collection, two monnted ones. I never saw one in Florida, hut they may go south, and some of them may be blne and he a liongh-leggert. Last fall one of my sons was out duck shooting and saict a black Marsh Hawk flew very near them. It was probably what we call a Iark Rough-leg. I once saw out at Dakota a Black Iroad-wing. It was sent to the sunithsonian I think.

Not much of anything new over this way except pichicking up and down the river. All join in lind regarts to yon and Mrs. Hallock.

lours as ever,

GEO. A. BOARUMAN.

MY DEAR IIALLOCK:

Calais, Sept. 8, 1899.

I an glal to hear you have heen having so pleasant a time at Mount Desert. I have not been there for twenty years and used to think it was about the nicest place on the coast of Haine. I am also very whl to hear that Mrs. IIallock is feeling so much better.

I was sorry to hear yesterday of the death of one of your old Denuysville neighbors, Deacon Vose, who died very suddenly. I have known him since my boyhood - a very nice man. I was 
sorry to hear of the death of oll Mr. MeIellan, which I read an account of in the paper. And that old horse joekey of a fellow that you sent me the eutting about was a wonder. 'Those horse joekeys are a set who most always die young, like the good ehilIren we read abont in the Sunday school books; but this old fellow is a wonder.

I was much pleased with what you said about Mr. Downs. Ile was a nice man. I have been at his place a number of times and he has visited me. I was in Halifax soon aftel the Prince of Wales was there in 1860 to have his great reception and this is the story some of the people told me.

'The Prince hat a long passage over and got to the back bay near Dowus' place on sunday. 'Their commander in charge allowed the Prince and a couple of his young friends and oflicers to go on shore to have a rum. 'They landed near Downs' place and went direct to his house. Mr. Downs was told by one of the young ofticers who they were and was introduced to the Prince. Then of course Downs entertained him like a prince - showerl him all he had and gave him his best set of moose horns to be put over his mother's best door in the Royal Palace.

'The next morning IJalifax was dressed up for the greatest reception it ever had. All the notables of Canada and other places were on the platform, also the Prince, waiting for the great performance to begin, when among the crowd upon the 1hoor was an old rough eustomer by the name of Downs. The Prinee saw him, knew him, lan down boy-like, and shook Mr. Downs with both hands, then led him up on the platform and introducer him to all his shipmates, oflicers and members of the party. 'The crowd was amazed to know how it could be that the Prince should shake hands with Downs before he did with any of the governors or the big oflicers of Canada and was also amazed to kuow how Mr. Downs and the Prince should appear such old eronies and when he got down from the platform everybody who could get a chance was shalking hands with Mr. Downs, while after the Prince Mr. Downs was the greatest man in Halifax for the day. Mr. Downs was paid $\$ 150$ in gold for the horns.

My brother Gorham was in bed most of the four weeks he was hele. He left me two weeks ago and I hear is much better 
now. Ife is at Chatham, cane Col. I will try to see what I can do with Mr. Downs' collection. 'The Cambridge eolleetion is very full. Your legs must be good to allow you to elimb the Mt. besert mountains; my legs now are hetter for going down than up hill. We are all very well here and the weather is line and cool. All join in lind reginds to you and Mrs. Halloek.

Sincerely yours,

Geo. A. Bonkdian.

Dr. Thomas Mayo Brewer who, with Prof. Baird and Mr. Robert Ridgway, spent several years in bringing out the History of Nortlı American Birds in five volumes, was one of Mr. Boarduran's correspondents and visitecl him several times at his home in St. Stephen. He was a native of Boston where he was born November 21, 1824, a graduate of Harvard university in the class of 1835 and of the Harvard Medical School in 1857. He organized the publishing firm of Brewer \& 'Tileston, which was in business for many years. He edited an edition of Wilson's American Ornithology and in 1859 the Snithsonian Institution published his Oology of North America. His work on the History of North American Birds was in the biographies of the species, while the technical descriptions were written by Prof. Baird and Mr. Ridgway. During the years 1875 and 1876 Dr. Brewer visited Great Britain and the European continent, spending much time in a personal examination and study of the great ornithological collections in those countries.

Writing to Mr. Boardman under date of May 20, 1868, Dr. Brewer says: "I an glad yon have the nest and eggs of the Canada Jay. It is a great prize. Let me have the nest to describe before you let it go out of your hands. The same in regard to those of the Pine Finch 
and the Goshawk. I want very much to see the finches in order to determine whether either of the three pretenders I now have are genuine. If you ever part with any egg of either of these three please give me the first chance unless I find I have already one of the finch's eggs."

In $1871 \mathrm{Mr}$. Boardman sent Dr. Brewer a nest and eggs of some unknown bird and the latter writes him November 23 of that year that "it is a regular puzzler." 'Then he says that he has gone completely through the entire list of North American land birds " and there are but few of our known birds to which it can possibly be attributed." Giving the possibilities of the birds to which they may belong he says there are objections to all of them, concluding by saying: "When I go to Washington this winter I will take it up and talk it over with Baird and let you know. But I doubt if he can see his way out of the fog. What an awful pity you could not have secured the bird." So far as the correspondence discloses, the identity of the nest was never established.

In 1874 Dr. Brewer wants Mr. Boardman to come to Boston. "I want very much," he says, "to talk with you about some of our water birds" and he sees no opportunity to visit St. Stephen. In this same letter, date of June 23, he writes: "I am glad you have taken the nest and eggs of the collaris. It is a great prizeahmost unknown. Where was the nest? On the ground I presume. Please give me all the particulars. Shall you have an egg to spare for your humble servant?" Writing June 29, 1877, to Mr. Boardman, accompanying a package of about fifty rare eggs, Dr. Brewer closes a most interesting letter by saying: "How would you 
like to have ne next May drop down to the region of black flies and nuake an excursion with you "up the creek?' Or shall we then be too old?" It was the last letter from Dr. Brewer founcl anong the papers of Mr. Boardman. He died at Boston, January 2t, 1880.

Mr. Joel Asaph Allen, now the curator of vertebrate zoology at the Anerican Museum of Natural History, Central Park, New York city, was one of Mr. Boardman's correspondents. He was born in springfield, Mass., July 19, 1838. He was a student under Agrassiz at the Lawrence scientific school of Harvard University; a nember of several scientific expeditions, and assistant in ornithology in the Harvard Museum of Conparative Zoology. Mr. Allen was the first president of the Anerican Ornithologists' Union, serving from 1883 to 1890. He edited the Bulletin of the Nuttall Ornithological Clinb, and has for some years been editor of The Auk, the leading ornithological review in this country. He has occupied his present position since 1885.

The correspondence between these friends began in 1864 , and was continued at intervals until 1886. Writing to Mr. Boardman Decentber 3, 1886, Mr. Allen says : "In regard to the Messina Quail I can only say that none have ever returned to breed where they were turned out. It is the opinion of those who have watched most carefully the experiment of their introduction that it has been a complete failure. In several instances they reared young the first year after being turned out, but disappeared the following winter never to return. It is the general belief that in migrating they struck out to sea and were lost." On October 26, 1869, in writing Mr. Allen, Mr. Boardman tells of obtaining two birds 
new to 1his list, the Black Vulture and Purple Gallinule, " both in very fine plumage and both taken while Prof. Baird was with me. They were a long ways north for such southern birds." Under date of November 12, 1864, Mr. Boardman writes Mr. Allen:

In answer to your question of how the White-heided Eagle breeds, I would say I have known but one instance of its breeding upou cliffs, that was at the Wolves Island. I was told by the fishermen of an eagle breeding upon the eliffs and supposed it was the Golden, so I sent a crew to get the eggs but they finding it the White-head did not go over the cliffs, but amused themselves by rolling roeks down over the nest but did not drive the birds away. I do-not, however, know whether they returned next year or not. I got a nest of raven's eggrs, seven in number, on a clifl near the same place last spring on $A_{1}$ ril 11 , the snow then being nearly a foot deep. The Duck Hawks breed very earlythey are flying about in June. I got one which I mounted but could see no pin feathers. It was shot this year in July, a this season's bird. T'hey are very quiet about breeding time and are seldom seen. I know of one place where they had been breeding for years and the fishermen living within half a mile never saw or heard of the bird. I have many times wondered how they could feed themselves and their young and never be seen, but when the young are half fledged they are at times very noisy, and when they first begin to fly more so than most hawks, but they leave the breeding phaces as soon as they can fly. I never knew them to breed upon trees. I once knew of a Raven's nest within a hundred yards of the hawk, and do not think they troubled each other. I also found, last year, a sparrow IJawk and Yellow Woodpecker breeding in the same tree, but they were not very peaceable. The IIawk would dive after the Woodpecker when it left its nest. Mr. Jitimson, a fine old man of Deer Islaud, told we a story of seeing an eagle flying along the elift and a Duck Iawk flew at the eagle in a very spiteful way, probably to drive it away from the nest, when the eagle caught the hawk, gave it a suneeze, and it dropped perfectly dead. It was seen by the whole boat's erew who were fishing. 
Elliott Cones was born in Portsmonth, N. H.. September $9,18+2$, and became a very prominent naturalist and writer on ornitlological subjects. Soon after grachnating from Colnmbian University, Washington, D. C., he entered the army as a medical cacket, became assistant surgeon in 186t, but resigned in 1881 to devote his life to science. He was naturalist to several exploring surveys of the government, as the Northern Bonndary survey and the Survey of the Territories and was also a collaborator at the Sunithsonian Institntion. At different times he was editor of various scientific journals and magazines and the anthor of no less than fourteen elaborate works on ornithology, together with several hundred monographs and scientific papers in reviews and other periodicals. Among the most important of his works are Key to North American Birds; Field Ornithology; New England Bird Life; North American Rockentia, Birds of the Colorado Valley, and Ornithological Bibliography. Dr. Coues was a member of the National Academy of Sciences, of many American and foreign scientific societies and was one of the scientific editors of the Century Cyclopredia and Dictionary. He died at Johns Hopkins Hospital, Baltimore, Md., December 25,1899 . A Memorial, from the pen of D. G. Elliot, with portrait, appeared in the number of The Ank for January, 1901, Vol. XVIII., page 1.

Many letters passed between Mr. Boardman and Dr. Elliott Coues relating to the Black Robin of which a history is given on pages 121-122 of this work. In one of those written by Dr. Coues on August 30, 1877, he says: "The case is one that should properly go on record and I hope you will make a note of this for the 
Nuttall Bulletin. I hope the youngster may stay black and that, as live birds are 'mighty uncertain' you have hin sacrificed to science in due time and sent to the Smithsonian where all good birds go - or ought to go when they die." This letter was written at Oakland, Ind., and he adds: 'I am taking a little 'vacation,' so called, by euphemism, though I don't see much difference. I seem condemned to the galley for life."

Mr. Ruthven Deane, writing from Cambridge, Mass., to Mr. Boardman, July 16, 1872, says: "I was pleased to hear of your taking a specimen of Vireo Philadelphicus. Mr. Brewster and myself took three females at Umbagog Lake in June. Your specimen now makes the fifth taken in New England." February 10, 1874, he writes: "I was much surprised to find that the Nyctale Richardsonii has been taken in your vicinity in spring, as it has generally been thought that only the coldest winters drove it into the limits of the United States." On November 11, 1876, Mr. Deane says :

We have had a very early and uncommonly large flight of Snowy Owls since the first of the month ou our coast and it is hard to conjecture the probable eause, especially as they appeared in such mild weather and to my knowledge no other so northern a species lias been driven south in numbers. My object in writing is to ask if you have had many in your section or if to your knowledge any have been taken on Grand Manan. I bave learned of nearly two huudred speeimens having been seeu and shot between Sico, Me., and New Bedford, Mass., and the majority were shot. Nost of them have been taken on the coast although numbers have been seen in country towns and a few have been seen perched on the housetops in Boston, Charlestown, ete. 
Letter from Lieut-Gov. Arthur H. Gordon to Mr. Boardman

Frenericton, .July 15, 1863.

MY DEAR SIR:

I was much obliged to you for the trouble you took in proenring we the squirrels. 'They arrived all safe and very pretty little creatures they were, but alas! only two or three days after they came theil eage was found empty some stupid person having allowed them to escape or some ill-disposed person having stolen them! It was a great disippointment to me as I hacl fully intended to take them with toe to England for the Zoological Gardens. I cannot ask you to take so much trouble again in procuring we another pair, but should you heme of one perhaps you will kindly remember that I am looking ont for some and that 1 am quite ready to pay well fol them.

'There is another animal which I am lather anxions to add to my collection, the tisher or peciuan. It is, I believe, very rire. I have never seen even a dead speeimen.

We have been parched for want of rain but it is falling now at last.

Pray do not forget the list of birds and beasts you were good enourh to promise that you would eontribute to my Report to the Queen. If a few words as to the habits, appearance, etc., of each species were added it would much increase its value.

lours very sincerely,

ARTHUR H. GORDON.

\section{Letter from Prof. L. W. Bailey to Mr. Boardman}

Fredericton, Jume 5th, 1874.

\section{MY DEAR SIR:}

Many thanks for your kind letter of the 26th ult. and for your generous answer to my somewhat bold rernest. The birds you mention will be a very great adtition to this part of our cabinet, and will, I trust, do much to awaken a more greneral interest in the whole.

I dare say that our students eould do something in the way of egg collecting, but I lave felt a little reluctant to encourage them iu this direction, as I have somewhere read or heard (perhaps 


\section{THE NATURALIST OF THE ST. CROIX}

from yourself) that eggs, uuless thoroughly identified at the time of collection as belonging to any particular species, are useless or worse thin useless, being liable only to produce confusion. Our students at this season are also too busy preparing for coming examinations to devote much attention to collecting. Unfortunately my most promising student in natural history, and one who had already done a yood deal in the way of preparing skeletons, etc., was suddenly carried ofl last winter by searlet feverthe only deatll which has ever oecurred among the students of the college.

I am glad to hear that your California trip was such a pleasant one. I have always had a yearning to see some of the wonders of the west, but am afraid that it will be long before I can get there.

I hope you will not abandon your idea of a visit to Frederieton and the St. John river this summer. I shall myself be away on the geological survey after July 1, but the family will be at home except during the first fortnight in July (when they propose to go to Campobello) and will be glad to see you. My own headquarters for a time at least after going from home will be at Hampstead Village near Loug Island on the St. John river, not fir from the place I told you of two or three seasons ago. Could you make it convenient to come there any time in the early part of July; I doubt not that you would find good sport on the hills and lakes which abound in that vicinity.

As you speak of a number of birds as being already monnted, it has oceured to me that it might be as well to send them at once, if convenient, as they will thus serve to make a better display at our coming commencement. By the way, have you any specinen of the little yellow eauary-like bird here known as the 'Thistle-bird? I should like very much to get one.

Please give my bind regards to Mrs. Boardman and believe me, Yours very truly,

L. W. Bailex. 



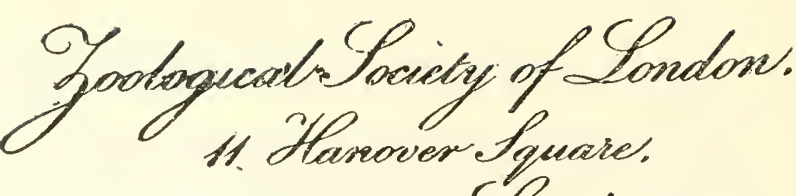

Sondon.w.

Cunftish 1865

Dear $\sqrt{\text { in }}$

Thar your letter of Setp g1, ano mant apologizer for wh having uptio long ago. We taw a prot frion at Livesporl in MV Moore, Curato of the Derby Mnseam, ano andthis you may saw to that poit as serres to his care is row ti. reach as sofely.

Coub you suander traws sme at ary tisin a coush of specinem of Chordiciles in spirits, or their skeletors. I wunt ti conso are the buteolony of this bivo with the with - Vory huly your' Ceop 2 Bowamm Sid. Clater STeptear hew Druns wick. 


\author{
Letter from Prof. P. L. Scluter, London, Eng., to \\ Mr. Boardman
}

I.oNion, Jan. 3d, 1865.

DEAR SIR:

You nust, I fear, consider me a very bad correspondent for not having previously replied to your letter of July last. We shall be glad to take advantage of your kind offer to supply some of the mammals of your country which are deficient in our series, but as you say, the difliculty is the transport.

The only plan, I think, is to place a few animals on board any ship you may find running into the Thames, uncler the charge of the ship"s butcher, giving him a letter to me requesting payment of $10 \mathrm{~s}$. or $20 \mathrm{~s}$. per head for such of them as he shall delivel alive in this country. It will be necessary to get the eaptain's permission, of course, bnt this you will not find difficult with your connections.

We receive a good many animals from the Australian colonies which are sent over exactly in this way.

As regards my own collection which you so kindly oller to assist, what I now most want are the sterna of birds of which I an now forming a collection. If you could send me a few of these belonging to American genera not represented in Europe (such as Tyrannus, Tyranga, Podilymbus, ete.) I should be grateful. You might send them quite in the rough as I ean get them polished up afterwards, but they should be correctly labelled.

I shall soon be able to send you a new edition of our list of living animals.

Very truly yours,

P. I. SCI.ATER.

Letter from Charles $E$. Aiken to Mr. Boardman

Colorado Springs, Colo., Oet. 9, 1877.

Mr. GeO. A. BOARDMAN :

Dear Sir-I have just received your favor of the 3 d inst. Tour Robin is certainly a very interesting specimen. 'I'lie transition of black to white in the plumage of birds I have never heard of before, and it indicates an analogy in the canses which 


\section{THE NA'TURALIST OF THE ST. CROIX}

prodnce these abnormal stages, which I did not suppose existed. As a callinet specimen the bird would doubtless be more valuable in its present plumage than it will be if it becomes entirely white, but I should consider the loss compensited for by the interest you will take in observing developments. My suggestion is that you have the bird photographed and spare his life a little longer at any rate. It would be interesting to observe what effect, if any, would be produced by plucking the old plumage from a eertain spot on the body - as the head - I believe that in all pure albinos the skin, like the plumage, is eolorless. I should suppose that in melanotic specimens the skin would be black or at least quite dark. If this was the case in your birds, does the skin lose color simultaneously with the appearance of the white featliers:

I have ohtained a perfect albino myself this fall - a gray wolf - which has even the nose and eyelids withont color. I have heard of two albino Buteo borealis.

If 1 succeed in getting :u adult Golden Fagle this winter I will remember your want and shall be happy to exchange for some of your specimens. Eagles were formerly quite plentiful here but so many lave been killed by hunters and sportsmen that they are not often obtained now. I received one about two weeks ago but in inmuatme plumage.

I have been wanting to secure an Everglade Kite for a long time. 'There are a number of other Florida hirds which I need but this one is the most important.

Yon speak of Sage Grouse - do you need any? I am thinking some of taking a trip over the "Range" this fall and if I do I expect to be able to get specimens of the Sage Grouse as well as Dusky Grouse and Ptarmigan.

Yours truly,

Chias. E. AiKen.

\section{Letter from Dr. Ezekiel Holmes to Mr. Boardman}

Winthrop, Dee. 30, 1862.

Geo. A. Boardian, Ese.:

My Dear Sir - Many thanks to you for your catalogue of birds and also for your communication of the $23 \mathrm{~d}$ inst. 
I am happy to find you still keeping your ornithological eye on the wath for new specimens and am glad that you are so suecessful in finding new comers. I feel a great interest in this department of natural history, especially as it regards our own State. It is a pity that naturalists have made so many new names for birds long ago appropriately named. It loads the seience with synonyms without eorresponding benefit. Names are, in one sense, arbitrary and adopted merely to enable us to identify an individual, or individuals by the hearing of it, while that name should be descriptive; but whether it be or not, when it has been promulgated that should be enough, and not subjeet to ehange for light eauses.

I did not get down so far as Calais last summer, but hope to if the Scientific Survey of the State should be continued. I have jnst finished my preliminary report on the fishes of Naine, as far as investigated this past season. I have made no ehanges in classifieation or nomenelature, but have taken my own mode of telling my story with a view of making it as familiar to "the masses," as the politicians say, ats I could, or at least, as much so as the seientific phrases and technieal terms would let me. I will seurd you a copy when published. I suppose I have about a quarter part, or perhaps half of the tishes which are, or are to be found in our waters, on my list of this year. If we go on, I must come down into your section early to learn what I ean of herriugs and herring fisheries in Maine and neighborhood, and if I do, will be linply to call upon yon. In the mean time I remain,

'Truly and cordially yours,

E. IIolmes.

P. S. Any facts, or even "sailors" yarns " and "fish stories" that may come to your knowledge in regard to fish and tishing in Maine, will be interesting and valuable to me if you will send them.

Letter from Dr. A. L. Heemann to Mr. Boardman

Philadelpila, May, 186iz.

\section{Dear Frieni Boardian:}

I received your box three days ago for which I have many thanks to return as there were several new species to my collection. The Ravens were certainly the largest sized ones I ever saw 


\section{THE NATURALIST OF THE ST. CROIX}

and should not wonder if Baind on receiving his should make a new species of it. Your eggs were also all desirable, the owl new to me; the snipe finished out a series of four I have long been trying for, and the Black (aptit appears so different from the eggs here that 1 should feel obliged to you if you can procure me one of the bilds of which you sent me the eggs. I am on the lookout for some birls' skins for you and will try to make an enroy hefore I leave here. Our spring has set in and we have now the warbler's in abundance which are traveling on their northward course. Pay particular attention to them and their eggs as I am almost without any of them in my collection, but I hope one of these days to find them in that northern region which I most earnestly desire to visit. In your letter you say that among my duplicates there were several desirable birds and now I ask why you did not take them? Pleave send me a list of what you wish and you shall have an that I have among my duplicates, as they are iutended for that purpose. I an now hard at work collecting what I can and some of our spring birds are already breeding. Mr. Kirder is not perfectly well and finds it out of his power to come and pay you a visit as his atlairs in the sutler business in our army are in such a condition that he caunot leave her for some time. I should like very much to see your supposed eagles" eggs and especially if the nest was found on the rocks. Our common Bald Eagle always builds on trees, our Golden Eagle on rocks, but the eggs are very much freekled with red and brown spots which does not appear to be the case with yours. Mr. lirider was nuch pleased to ste the eggs of the English snipe, and if you get any more please send a pair to him. With regard to any warblers' egge you may have I shall be very glad to have them even though not thououghly identified as I might go to Washington aud study them out with or from P'rof. Balirl's collection. He has just seut ule a set of eggs among which are many new species to my collection and I begin again to hope that some of these days I shall have a show of the North American species. Could you not obtain some of the liaven's eggs of which you sent me the bird? 'The fact is, that I would like to impress on your mind that even the commonest species breeding in your part of the country would be valuable both to John Krider and myself. 
I have not, for instance, a well authenticated egg of the Wood Duck or Dusky Duck, which both appear to be eommon with you.

I want as soon as you ean make out a list of desired birds to send it to me at once and I will see what I can do to fill it. Much obliged to you if you can get me the eggs marked on the English list, and I gave you at the same time a list of what $A$ merican egas I could supply and if the gentleman desires any of them let me know it at once.

Your friend,

\section{A. I. HEEMANN.}

Among Mr. Boardman's papers have been found many letters from amateur and little known naturalists who wrote to make inquiries respecting puzzling matters in ornithology or to thank him for specimens sent or information given. Here is a specimen that is most gratifying. It was written by William H. Hoyt, Stamford, Conn., and bears date August 24, 1886, but only the opening paragraph of the long letter is given:

Your letter came duly to hand and yesterday A. M. the box of eggs and skins arrived, and I think that during the half honr I took to unpack it I was as near the summit of human happiness as man ever attains. Being an enthusiastic naturalist yourself, if you will eall to mind some boxes you have perhaps received from the smithsonian or elsewhere, and remember the delight of unpacking it, you will know how the treasures you sent affected me. I think there is no pleasure so healthy, so full and so satisfactory as that which comes with the gratifieation of a naturalist's desire. I will of course make one exception - that of human love and friendship. I never was so pleased with a box befole, hecause I never have had anything so rare as the specimens it coutained.

Many letters of a similar nature are among the papers, showing to what a large extent Mr. Boardman was sending specimens to distant ornithologists and carrying on a constant correspondence with lesser known naturalists as well as with those who were fan1ous. 


\title{
CIAPTER XI
}

\section{SCIENTIFIC LISTS}

\begin{abstract}
NEXT to his large collection in ornithology the 1 work that gave Mr. Boardman great authority as a naturalist and brought him into correspondence with so many students who had never seen his collection were the lists of the fauna of the St. Croix valley which he published from time to time in the scientific journals. The basis of his list of birds were those first published in the Proceedings of the Boston Society of Natural History in 1862, Vol. IX., pages 122-233. As his interest in the natural history of his locality widened Mr. Boardman studied all its branches and, as was his custom, made records of all his observations. The following lists embrace the results of his studies in the faunal distribution of Maine and New Brunswick.

These lists were finally revised by Mr. Boardman and published in the colımns of the Calais Weekly Times between November 23, 1899 and February 5, 1900, the old scientific nomenclature being used. But owing to our increased knowledge of the relations which different families and species of birds bear to each other the generic names of many species have been clianged since Mr. Boardman's list was originally published.
\end{abstract}


Also in scientific nomenclature it is the custom to give the first scientific name applied to a species as its correct name and treating all subsequently applied names of that species as synonyms. In accordance with this latter custom it has been found necessary to cliange the long-accepted names of many species for others which were applied by other scientists at earlier dates and which therefore had precedence. For these causes the nomenclature originally used in connection with $\mathrm{Mr}$. Boardman's list differed quite essentially from that now accepted by science. To have published the list of birds with the old nomenclature would have perpetuated errors and employed a language obsolete to science. Therefore the list has been revised to correspond with that of the American Ornithologists' Union. In other particulars Mr. Boardman's list as published in the Calais 'Times remains unchanged.

In the list of fishes the authority followed in nomenclature las been 'The Fishes of North and Middle America, by David Starr Jordan, president of Leland Stanford Junior University and Barton Warren Evermann, Icthyologist to the United States Fish Commission, in four volumes, being Bulletin No. 47 of the United States National Museum, Washington, D. C., 1896-1900. In the list of mammals the authority has been American Animals: A Popular Guide to the Mammals of North America north of Mexico, with Intimate Biographies of the More Familiar Species, by Whitmer Stone and William Everett Cram, New York, 1902. In the list of reptiles the authority has been The Century Dictionary and Cyclopedia, New York, 1899. 


\section{St. Croix Bircis}

Wilson's Thrush. Hylocichla fuscescens (Stcph.). Not uncommon; breeds.

Olive-backed Thrush. Hylocichla ustulata swainsonii $(C a b$.$) . Not plentiful in summer; some breed.$

Hermit Thrush. Hylocichla guttata pallasii ( $\mathrm{Cab}$.$) .$ Very abundant ; one of our best songsters.

American Robin. Merula migratoria (Linn.). Abundant everywhere.

Cat-bird. Galeoscoptes carolinensis (Linn.). Not very abundant ; breeds.

Stone cliat. Saxicola œnanthe leucorhoa ( $\mathrm{Gmcl}$.). Accidental, only two specimens.

Bluebird. Sialia sialis (Linn.). Not conmmon; few breed.

Ruby-crowned Wren. Regulus calendula (Linn.). Rare; may breed.

Golden-crowned Wren. Regulus satrapa Licht. More conmon; few remain all winter.

Black-capped Clickadee. Parus atricapillus Linn. Common, winter and summer.

Hudsonian Chickadee. Parus hudsonicus Forst. Not very abundant ; few breed.

White-bellied Nuthatch. Sitta carolinensis Lath. Rare; breeds.

Red-bellied Nuthatch. Sitta canadensis Linn. Abundant; breeds.

Brown Creeper. Certlia familiaris americana (Bonap.). Not very common; breeds.

Winter Wren. Olbiorchilns hiemalis (Vicill.). Resident; not abundant. 
American Titlark. Anthus pensilvanicus (Lath.). Common in migrations.

Black and White Creeper. Mniotilta varia (Linn.). Common; arrives early in May.

Prothonotary Warbler. Protonotaria citrea (Bodd.). Very rare, only a straggler.

Nashville Warbler. Helminthophila rubricapilla (Wils.). Common; breeds.

Tennessee Warbler. Helminthophila peregrina ( Wils.). Common; breeds.

Blıe Yellow-backed Warbler. Compsotllypis americana usnere Brewster. Not uncommon; breeds.

Cape May Warbler. Dendroica tigrina (Gmel.). Rare, some years common; breeds.

Summer Yellow Warbler. Dendroica æstiva (Gmel.). Abundant ; breeds.

Black-throated Blue Warbler. Dendroica cærulescens (Gmcl.). Not abundant all summer.

Yellow-rump Warbler. Dendroica coronata (Linn.). Very abundant ; comes early.

Black and Yellow Warbler. Dendroica maculosa $(G m e l$.$) . Abundant; breeds.$

Chestnut-sided Warbler. Dendroica pensylvanica (Limn.). Not uncommon; breeds.

Bay-breasted Warbler. Dendroica castanea (Wils.). Not uncommon; breeds.

Black-poll Warbler. Dendroica striata (Forst.). Not uncommon; breeds.

Blackburnian Warbler. Dendroica blackburniæe (Gmel.). Not uncommon; breeds.

Black-throated Green Warbler. Dendroica virens (Gmel.). Abundant; breeds. 
Pine-creeping Warbler. Dendroica vigorsii (Aud.). Very rare; only one specimen.

Yellow Red-poll Warbler. Dendroica palmarum hypochrysea Ridgw. Very abundant ; breeds.

Golden-crowned Thrush. Seiurus aurocapillıs (Linn.). Very abundant; breeds.

Small-billed Water Thrush. Seiurus noveboracensis (Gmel.). Common; breeds.

Mourning Warbler. Geothlypis philadelphia (Wils.). Very rare.

Maryland Yellow Throat. Geothlypis trichas brachidactyla (Swain.). Abundant; breeds.

Wilson's Black-capped Yellow Warbler. Wilsonia pusilla (Wils.). Not very abundant; breeds.

Canadian Flycatching Warbler. Wilsonia canadensis. (Linn.). Common ; breeds.

American Red Start. Setophaga ruticilla (Linn.). Very abundant ; breeds.

Red-eyed Vireo. Vireo olivacens (Linn.). Very abundant; breeds.

Philadelphia Vireo. Vireo philadelphicus (Cass.). Rare.

Warbling Vireo. Vireo gilvus (Vicill.). Not plenty; remains all summer.

Blue-headed Vireo. Vireo solitarius (Wils.). Not plenty; remains all winter.

Great Northern Shrike. Lanius borealis (Vicill.). Fall and winter; common.

White-rump Shrike. Lanius ludovicianus Linn. Rare; breeds.

Northern Wax Wing. Ampelis garrulus Linn. Rare; some winters in large flocks. 
Cedar Wax Wing. Ampelis cedrorum (Vieill.). Conmon, sonce in winter; breeds.

Purple Martin. Progne subis (Linn.). Common; breeds.

Cliff Swallow. Petrochelidon lunifrons (Say). Very abundant; breeds.

Barn Swallow. Hirundo erytlırogaster Bodd. Very abundant ; breeds.

White-bellied swallow. 'Tachycineta bicolor (Vicill.). Very abundant ; breeds.

Bank Swallow. Riparia riparia (Linn.). Very abundant ; clieap.

Scarlet Tanager. Piranga erythromelas Vicill. Rare ; breeds.

Summer Red Bird. Piranga rubra (Linn.). Grand Manan. Rare; only two specimens.

Pine Grosbeak. Pinicola enucleator leucura (Muller). Common in winter; a few in summer.

Purple Finch. Carpodacus purpureus (Gmcl.). Abundant ; breeds.

American Crossbill. Loxia curvirostra minor (BrChm). Uncertain, some winters abundant ; breeds in winter.

White-winged Crossbill. Loxia leucoptera Gmel. Uncertain, some winters abundant; breeds in winter.

Common Red Poll. Acanthis linaria (Limn.). Winters common; breeds.

American Gold Finch (Thistle Bird). Astragalinus tristis (Linn.). Abundant; breeds.

Pine Fincl.. Spinus pinus (Wils.). Winter visitant ; some breed.

Snow Bunting. Passerina nivalis (Linn.). Winter visitant. 
304 THE NATURALIST OF THE ST. CROIX

Lapland Longspur. Calcarius lapponicus (Linn.). Very rare.

Savannah Sparrow. Ammodramus sandwichensis savanna (Wils.). Abundant; breeds.

Grass Finch. Poccetes gramineus (Gmel.). Abundant ; breeds.

Yellow-wing Sparrow. Ammodramus savannarum passerinus (Wils.). Very rare; accidental.

Sharp-tail Fincls. Ammodramus nelsoni subvirgatus (Dwight). Not plenty.

White-crowned Sparrow. Zonotrichia leucophrys (Forst.). Very rare.

White-throat Sparrow. Zonotrichia albicollis ( $\mathrm{Gmcl}$.). Abundant.

Tree Sparrow. Spizella monticola $(\mathrm{Gmel}$.). Only in migrations.

Clipping Sparrow. Spizella socialis (Wils.). Very abundant.

Black Snow Bird. Junco liyemalis (Linn.). Very abundant.

Song Sparrow. Melospiza melodia (Wilson). Very abundant.

Swamp Sparrow. Melospiza georgiana (Lath.). Not uncommon.

Lincoln's Finch. Melospiza lincolnii (Aud.). Very rare.

Fox-colored Sparrow. Passerella iliaca (Merr.). Fall and spring.

Rose-breasted Grosbeak. Zamelodia lıdoviciana (Linn.). Rare; breeds.

Blue Grosbeak. Guiraca cærulea (Linn.). Grand Manan; accidental. 
Indigo Bunting. Cyanospiza cyanea (Limn.). Not uncommon; breeds.

Bobolink. Dolichonyx oryzivorus (Linn.). Very abundant.

Cow Bird. Molothrus ater (Bodd.). Rare.

Red-winged Blackbird. Agelaius phœniceus (Linn.). Abundant.

Meadow Lark. Sturnella magna (Linn.). Very rare; only accidental.

Orcliard Oriole. Icterus spurius (Linn.). Very rare; only acciclental.

Baltimore Oriole. Icterus galbula (Limn.). Not common; rare.

Rusty Blackbird. Scolecophagus carolinus (Miill.). Common in migrations; few in summer.

Purple Grackle. Quiscalus quiscula æneus (Ridgw.). Very abundant.

American Raven. Corvus corax principalis Ridgw. Not abundant ; breeds.

Common Crow. Corvus americanus Aud. Common, resident.

Blue Jay. Cyanocitta cristata (Linn.). Commou, resident.

Canada Jay. Perisoreus canadensis (Linn.). Common, resident.

Shore Lark. Otocoris alpestris (Linn.). Very rare.

King Bird. 'Tyranuus tyranuus (Limn.). Very abundant.

Great Crested Flycatcher. Myiarchus crinitus (Limn.). Very rare.

Phobe Bird Pewee. Sayornis phœbe (Lath.). Rare.

Olive-sided Flycatclier. Contopus borealis (Swains.). Nót uncommon; breeds. 
Wood Pewee. Contopus virens (Linn.). Not uncommon; breeds.

Yellow-bellied Flycatcher. Empidonax flaviventris Baird. Not uncommon; breeds.

Traill's Flycatcher. Empidonax traillii alnorum Brewst. Not uncommon; breeds.

Ipswicl Sparrow. Ammodramus princeps (Mayn.). St. Andrews; two.

Least Flycatcher. Empidonax minimus Baird. Abundant.

Ruby-throated Humming Bird. Trochilus colubris Linn. Abundant.

Chinney Swift. Chætura pelagica (Linn.). Abundant.

Whippoorwill. Antrostomus vociferus (Wilson). Not uncommon.

Night-hawk. Chordeiles vitginianus (Gmel.). Abundant.

Hairy Woodpecker. Dryobates villosus (Linn.). Abundant.

Downy Woodpecker. Dryobates pubescens (Linn.). Abundant.

Black-backed Three-toed Woodpecker. Picoides arcticus (Swains.). Not uncommon; few in summer.

Banded Three-toed Woodpecker. Picoides americanus Brehm. Not uncommon; few in summer.

Yellow-bellied Woodpecker. Sphyrapicus varius (Linn.). Common.

Pileated Woodpecker. Ceophlœus pileatus abieticola Bangs. Not uncommon.

Red-headed Woodpecker. Melanerpes erythrocephalus (Linn.). Very rare. 
Yellow-shafted Flicker. Colaptes auratus (Linn.). Abundant.

Belted Kingfisher. Ceryle alcyon (Linn.). Abundant. Yellow-billed Cuckoo. Coccyzus americanus (Linn.). Very rare; only accidental.

Black-billed Cuckoo. Coccyzus erythropthaluus (Wilson). Common.

Anerican Long-eared Owl. Asio wilsonianus (Less.). Not uncommon.

Short-eared Owl. Asio accipitrinus (Pall.). Not uncommion.

Barred Owl. Syrnium nebulosum (Forst.). Abundant.

Great Gray Owl. Scotiaptex cinerea (Gmel.). Very rare; only in winter.

Richardson's Owl. Nyctala tengmalni richardsoni (Bonap.). Not uncommon; winter.

Saw-whet Owl. Nyctala acadia (Gmel.). Common.

Little Screech Owl. Megascops asio (Linn.). Very rare; accidental.

Great Horned Owl. Bubo virginianus (Gmel.). Common.

Snowy Owl. Nyctea nyctea (Linn.). Some winters common ; uncertain.

Hawk Owl. Surnia ulula caparoch (Mill.). some winters common.

Gyrfalcon. Falco rusticolus gyrfalco (Linn.). This falcon not uncommon in winter.

White Gyrfalcon. Falco islandus Brïnn. Only one; Lincoln, Me. in Brewster's collection.

Black Gyrfalcon. Falco rusticolus obsoletus (Gmel.). Winter visitant ; three specimens. 
American Peregrine Falcon. Falco peregrinus anatum (Bonap.). Not uncommon; breeds on cliffs.

Pigeon Hawk. Falco columbaritis Linn. Not uncommon ; breeds on cliffs.

Sparrow Hawk. Falco sparverius Linn. Not unconmon ; more plenty.

Fish Hawk, Osprey. Pandion haliaëtus carolinensis (Gmel.). Abundant.

Marsh Hawk. Circus hudsonius (Linn.). Abtntlant.

Cooper's Hawk. Accipiter cooperi (Bonap.). Not common; one of our rarest hawks.

Sharp-shinned Hawk. Accipiter velox (Wils.). Abunciant.

American Goshawk. Accipiter atricapillus (Wils.). Not uncommon; breeds.

Red-tailed Hawk. Buteo borealis (Gmcl.). Not unconmon ; breeds.

Swainson's Hawk. Buteo swainsoni Bonap. Oct., 1892, one specimen.

Red-shouldered Hawk. Buteo lineatus (Gmal.). Not uncommon; breeds.

Broad-winged Hawk. Buteo platypterus (Vicill.). Abundant.

American Rouglileg. Archibuteo lagopus sancti-johannis (Gmel.). Very rare.

Golden Eagle. Aquila clirysaëtos (Linn.). Very rare; shot one in stummer.

Bald Eagle, Gray Eagle. Haliæetus leucocephalus (Linn.). Common; breeds.

Turkey Buzzard. Cathartes aura (Linn.). Very rare; only one specimen.

Black Vulture. Catharista urubu (Vicill.). Not uncommon some seasons. 
Passenger Pigeon. Fictopistes migratorius (Linn.). Not uncommon; all gone.

Mourning Dove. Zenaidura macroura (Limn.). Very rare; accidental.

Spruce Partridge. Canachites canadensis canacc (Linn.). Conmon.

Canadian Ruffed Grouse. Bonasa umbellus togata (Limn.). Common.

Great Blue Heron. Ardea herodias Linn. Connmon. American Egret. Ardea egretta Gmcl. Very rare; Grand Manan.

Snowy Heron. Ardea candidissima Gmel. Very rare; Grand Manan.

Green Heron. Ardea virescens Linn. Rare.

Black-crowned Night-Heron. Nycticorax nycticorax nævius (Bodd.). Rare.

American Bittern. Botaurus lentiginosus (Montag.). Very common.

Least Bittern. Ardetta exilis (Gmel.). Rare.

American Oyster-catcher. Hæmatopus palliatus Tcmm. Grand Manan; accidental.

Turnstone. Arenaria morinella (Limn.). Fall; not rare. Black-bellied Plover. Squatarola squatarola (Linn.). Not very common.

Golden Plover. Charadrius dominicus Miell. Not very common.

Semipalmated Plover. Aigialitis semipalmata Bonap. Common in sul11mer.

Piping Plover. AEgialitis meloda (Ord.). Rare; said to breed on the islands.

American Woodcock. Plilohela minor (Gmel.). Plenty ; breeds early. 
310 THE NATURALIST OF THE S'T. CROIX

Wilson's Snipe. Gallinago delicata $(O r d$.$) . Plenty;$ some breed.

Redbreasted Snipe. Macrorhamphus griseus ( $\mathrm{Gmel}$.). Rare.

Greater Long-beak. Macrorhamphus scolopaceus (Say). Rare ; St. Andrews.

Stilt Sandpiper. Micropalama himantopus (Bonap.). Rare.

Knot; Robin Snipe. Tringa canutus Linn. Rare; in river.

Purple Sandpiper. Tringa maritima Briinn. Abundant in winter; islands.

Pectoral Sandpiper. Tringa maculata Vieill. Common in fall.

Bonaparte's Sandpiper. Tringa fuscicollis Vieill. Rare.

Least Sandpiper. Tringa minutilla Vieill. Abundant in summer.

Red-backed Sandpiper. Tringa alpina pacifica (Coues). Rare.

Curlew Sandpiper. Tringa ferruginea Brinn. Accidental; St. Andrews and Grand Manan.

Semipalmated Sandpiper. Ereunetes pusillus (Linn.). Common.

Sanderling. Calidris arenaria (Linn.). Common.

Hudsonian Godwit. Limosa hæmastica (Linn.). Rare.

Greater Yellow-legs. Totanus melanolencus (Gmel.). Common, spring and fall.

Lesser Yellow-legs. Totanus flavipes ( $\mathrm{Gmel}$.). Common, only in fall.

Solitary Sandpiper. Helodromas solitarius (Wils.). Common. 
Willet. Symphenica semipalmata (Gmel.). Rare.

Ruff. Pavoncella pugnax (Linn.). Grand Manan; accidental.

Bartram's Sandpiper. Bartramia longicauda (Bechst.). Accidental.

Spotted Sandpiper. Actitis macularia (Linn.). Abundant.

Long-billed Curlew. Numenius longirostris Wils. Very rare.

Hudsonian Curlew. Numenius hudsonicus Lath. Very rare.

Eskimo Curlew. Numenius borealis (Forst.). Very rare.

Red Phalarope. Crymophilus fulicarius (Linn.). Not uncommon; few breed.

Northern Phalarope. Phalaropus lobatus (Linn.). Plenty in spring and fall; islands.

American Avoset. Recurvirostra americana Gmel. Accidental.

Black-necked Stilt. Himantopus mexicanus (Miill.). Accidental; St. Andrews.

Virginia Rail. Rallus virginianus Linn. Common.

Sora Rail. Porzana carolina (Linn.). Abundant.

Little Yellow Rail. Porzana noveboracensis (Gmel.). Several ; rare.

Purple Gallinule. Ionornis martinica (Linn.). Accidental ; two.

Florida Gallinule. Gallinula galeata (Licht.). Several.

American Coot. Fulica americana Gmel. Not uncommon. 
312 THE NATURALIST OF THE ST. CROIX

Snow Goose. Chen liyperborea ( $\mathrm{Pall}$.$) . Rare; Grand$ Manan.

Lesser Snow Goose. Clien hyperborea nivalis (Forst.). Accidental; Grand Manan.

American White-fronted Goose. Anser albifrons gambeli (Hartl.). Grand Manan.

Canada Goose. Branta canadensis (Limn.). Common.

Brant. Branta bernicla (Limn.). Common.

Mallard. Anas bosclias Limn. Accidental; very rare. Black Mallard. Anas obscura Gmel. Common.

Gadwall. Chaulelasmus streperus (Linn.). Very rare; accidental.

Pin Tail. Dafila acuta (Linn.). Very rare; accidental.

Baldpate; Widgeon. Mareca americana (Gmel.). Very rare; accidental.

Shoveller. Spatula clypeata (Limn.). Very rare; accidental.

Blue-winged Teal. Querquedula discors (Limn.). Common; breeds.

Green-winged Teal. Nettion carolinensis (Gmel.). Not cominon.

Wood Duck. Aix sponsa (Linn.). Common.

Scaup Duck. Aythya marila (Linn.). Not common.

Little Blackhead. Aythya affinis (Eyt.). Not common.

Ring-necked Duck. Aythya collaris (Donov.). Not uncommon; breeds.

Red-head. Aythya americana (Eyt.). Rare; breeds.

Barrows' Golden Iiye. Clangula islandica ( $\mathrm{mmcl}$.). Common in winter.

Anerican Golden Fye; Whistler. Clangula clangula americana (Bonap.). Common; resident. 
Buffle Head; Butter Ball. Charitonetta albeola (Linn.). Common spring and fall; breeds.

Harlequin Duck. Histrionicus histrionicus (Linn.). Islands; fall and winter.

Longtail; Old Squaw. Harelda hyemalis (Linn.). Abundant.

Labrador Duck. Camptolaimus labradorius ( $\mathrm{Gmcl}$.). Grand Manan; very rare, none of late.

American Eider Duck. Somateria dresseri Sharpe. Dresser. Abundant in winter.

King Eider. Somateria spectabilis (Limn.). Not rare in winter.

American Scoter. Oidemia americana Swains. Common.

White-winged Scoter. Oidemia deglandi (Bonap.). Common.

Surf Duck. Oidemia perspicillata (Linn.). Common. Ruddy Duck. Iirismatura jamaicensis (Gmel.). Not rare; breeds.

American Sheldrake. Merganser americanns (Cass.). Not rare; breeds.

Red-breasted Sheldrakc. Merganser scrrator (Linn.). Not rare.

Hooded Sheldrake. Lopliodytes cucullatus (Linn.). Not rare; breeds.

American White Pelican. Pelecanus erythrorhynchos Gmel. Accidental; one seen in Calais.

Common Cormorant. Phalacrocorax carbo (Linn.). Not abu11dant.

Double-crested Cormorant. Phalacrocorax dilophus (Sa'ain.). Common in migrations.

Gannet. Sula bassana (Linn.). Common down the bay. 


\section{THE NATURALIST OF THE S'T. CROIX}

Black Skimmer. Rhynchops nigra Linn. Accidental; down the bay.

Ivory Gull. Pagophila alba (Gunn.). Accidental; Grand Manan.

Bonaparte's Gull. Larus philadelphia (Ord). Very abundant; none breed.

Sabine's Gull. Xema sabinii (Sab.). Eastport; accidental in bay.

Gull-billed Tern. Sterna nilotica (Hasselq.). Accidental in bay.

Caspian Tern. Sterna caspia Pallas. Seen in migrations; rare.

Common Tern. Sterna hirundo Linn. Abundant.

Arctic Tern. Sterna paradisæa Briinn. Abundant.

Least Tern. Sterna antillarum (Less.). Accidental; Grand Manan.

Kittiwake Gull. Rissa tridactyla (Linn.). Abundant fall and winter.

Glaucous Gull. Irarus glaucus (Briinn.). Rare; only found in winter.

White-winged Gull. Larus leucopterus Faber. Rare; only found in winter.

Great Black-backed Gull. Larus marinus Linn. Winter bird; few breed.

Herring Gull. Larus argentatus Brünn. Common; resident.

Ring-billed Gull. Larus delawarensis Ord. Common in migration.

Laughing Gull. Larus atricilla Linn. Few about islands in summer.

Black Tern. Hydrochelidon nigra surinamensis (Gmel.). Accidental; Grand Manan. 
Pomarine Jaeger. Stercorarius pomarinus ( $T \mathrm{cmm}$.). Not plenty.

Richardson's Jaeger. Stercorarius parisiticus (Linn.). Rare.

Long-tailed Jaeger. Stercorarius longicandus Vieill. Common; fall.

Greater Shearwater. Puffinus gravis (O'Reilly'). Common.

Sooty Shearwater. Puffinus fuliginosus Strickl. Rare.

Stormy Petrel, Mother Carey's Chicken. Procellaria pelagica Linn. Accidental; only Grand Manan.

Wilson's Petrel. Oceanites oceanicus $(K u h l)$. Rare; only in summer.

Leach's Petrel. Oceanodroma leucorhoa (Vieill.). Common; breeds on islands.

Red-necked Grebe. Colymbus holbœllii (Reinh.). Common; breeds on islands.

Horned Grebe. Colymbus auritus Linn. Common; few breed.

Thick-billed Grebe. Podilymbus podiceps (Linn.). Connmon; breeds.

Loon. Gavia imber (Gunn.). Common; breeds.

Red-throated Loon. Gavia lumme (Gunn.). Common.

Razor-billed Auk. Alca torda Linn. Winter; few breed on Grand Manan.

Common Puffin. Fratercula arctica (Limn.). Winter; few breed on Grand Manan.

Sea Dove. Alle alle (Linn.). Winter only.

Black Guillemot. Cepphus grylle (Linn.). Resident ; breeds on islands. 
Foolish Guillemot. Uria troile (Linn.). Resident; few breed.

Brünnich's Guillemot. Uria lomvia (Linn.). Resident; few breed.

Fulmar Petrel. Fulmarus glacialis (Linn.). Winter sea bird; Grand Manan.

European Starling. Sturnus vulgaris Linn. Slot in Calais by Mr. Nichols.

\section{Fishes}

Yellow Perch. Perca flavescens (Mitch.).

White Perch. Morone americana (Gmel.).

Striped Bass. Roccus lineatus (Bloch.).

Pumpkin Seed. Enpomotis gibbosus (Linn.).

White Lake Bass. Roccus chrysops (Raf.).

Sancer-eye Porgy. Calanus calamus ( $C u v$.).

Weakfislı. Cynoscion regalis (Bloch.).

Common Mackerel. Scomber scombrus (Linn.).

Tunny, or Horse Mackerel. Thunnus thynnus ( $\operatorname{Linn}$.). Spanish Mackerel. Scomberomorus maculatus (Mitch.).

Swordfish. Xiphias gladius (Linn.).

Blunt-nose Shiner. Voner setipinnis (Mitch.).

Bluefish. Ponnatomus saltatrix (Linn.).

Bill-fish. Tylosurus marinus (Walb.).

European Stickleback. Gasterosteus aculeatus ( Linn.).

Many-spined Stickleback. Pygostcus Pungitius brachypoda (Bean).

Silverside. Chirostoma bartoni (Jordan and Evormann).

Redfish. Sebastes marinus (Linn.).

Sea Raven. Hemitripterus americanıs ( $\mathrm{Gmel}$.). 
Sculpin, Greenland Bullhead. Cottus grcenlandicus (Girard).

Common Sculpin, or Bnllhead. Cottus octodecin spinosus (Gill).

Labrador Northern Sculpin. Cottus labradoricus (Girard).

Sea Poacher. Aspidophoroides monopterygius (Bloch.).

Toad-fish. Batraclus Tau (Linn.).

Shanny. Blennius lævis.

Butter-fish. Pholis dolichogaster (Pallas).

Eel Pout. Zoarces anguillaris $(P c c k)$.

Lump-fish. Cyclopterus lumpus (Linr.).

Wolf-fish. Anarlichas lupus (Linn.).

Wrymouth. Cryptacanthodes maculatus (Storer).

Angler. Lophius piscatorius (Linn.).

Bank Cod (doubtful). Gadus callarias (Linn.).

Codfish. Gadus americanus (Gill).

Tomcod. Microgadus tomcod (Walb.).

Haddlock. Melanogrammus rglefinus (Linn.).

Pollock. Pollachius virens (Linn.).

Silver Hake. Merluccius bilinearis (Mitch.).

Burbot. Lota maculosa (Le Sueur).

Cusk. Brosmius brosme.

De Kay's Codling. Phycis de Kaii (Kaup.).

Ophiodon. Ophiodon elongatus (Girard).

Blackfish. Tautoga onitis (Linn.).

Cunner. Ctenolabrus adspersus.

Halibut. Hippoglossus hippoglossus (Linn.).

Common Flatfish, Flounder. Pseudopleuronectes americanus ( Walb.).

Spotted Flounder, Turbot, Window Pane. Paralichthys oblongus (Mitch.). 


\section{THE NATURALIST OF THE ST. CROIX}

Shiner. Notemigonus chrysoleucus.

Redfin. Notropis cornutus (Mitch.).

Dace. Rhinichthys cataractæ (Cuv. \& Valen.).

Roach Dace. Leuciscus rutilus (Raf.).

Creek Chub. Semotilus atromaculatus (Mitch.).

Red-sided Shiner. Leuciscus elongatus (Kirt.).

Brook Minnow. Fundulus heteroclitus (Linn.).

Common Sucker. Catostomus commersonii (Lacep.).

White Sucker. Moxostoma aureolum (Le Sucur.).

Chub-sucker. Erinnyzon sucetta.

Minnow Killifish. Fundulus magalis (Walb.).

Common Pickerel. Esox reticulatus (Le Sucur.).

Salmon. Salmo salar (Linn.).

Brook Trout. Salvelinus fontenalis (Mitch.).

Sea Trout. Salmo canadensis (Smith).

Landlocked Salmon. Salmo salar sebago (Girard).

Silver Salmon. Oncorhynchus kisutch ( Walb.).

Togue. Cristivomer namaycush ( Walb.).

Blue-black Trout. Oncorhynchus nerka (Walb.).

White or Gizzard Fish. Coregonus quadrilateralis (Rich.).

Conmon Whitefish. Coregonus clupeiformis (Mitch.).

Smelt, Fresh Water. Osmerus mordax (Mitch.).

Sea Smelt. Hypomesus pretiosus (Girard).

Capelin. Mallotus villosus (Muller).

Herring. Clupea harengus (Linn.).

Thin-head. Leptocephalus gracilis (Storer).

Catfish. Amiurus melas.

Sturgeon. Acipenser sturis (Linn.).

Porbeagle. Lamna cornubica ( $\mathrm{Gmel}$.).

Dogfish. Squalus canthias (Linn.).

Basking Shark. Cetorlinus maximus (Gunner). 
'Thresher Shark. Alopias vulpes (Gmel.).

Sleeper. Somniosus microcephalus.

Skate. Raia laevis (Mitch.).

Hedgehog Ray. Raia erinace (Mitch.).

Lamprey. Petromyzon marinus.

Common Shad. Alosa alabamx (Jordan \& Evermann).

Alewife or Gaspereau. Pomolobus pseudoliarengus (IVilson).

Menhaden, Mossbanker. Brevoortia tyrannus (Latrobe).

Brit. Clupea minima (Peck).

Autumnal Herring. Alosa mattonaca (De Kay).

Anchovy. Stolephorus encrasicholus.

Balistes. Balistes capriscus.

Sharp-nosed Eel. Anguilla vulgaris.

Eel. Anguilla Bostoniensis (Le Sueur).

Conger Eel. Leptocephalus conger (Linn.).

Sand Launce. Ammodytes americanus (De Kay).

\section{Mammals}

Shrew. Neosorex palustris (Verrill).

Foster's Shrew. Sorex Fosteri (Rich). Very rare.

Oared Shrew. Sorex platyrhincus (Wagner). Quite common.

Cooper's Shrew. Sorex Cooperi (Bach.).

Common Shrew. Sorex personatus (Geoffray).

Mole Shrew, short-tailed. Blarina brevicauda (Say).

Common Mole. Scalops aquaticus (Linn.).

Star-nosed mole. Condylura cristata (Linn.). Common.

Wildcat. Lynx ruffus (Guld.). Common. 
Loup-cervier. Lynx canadensis (Kerr). Common. Gray Wolf. Canis occidentalis (Rich.). Common. Red Fox. Vulpes fulvus (Desmarest).

Fisher Marten. Mustela pennanti (Erxleben).

Pine Marten or American Sable. Mustela americana (Turton).

Least Weasel. Putorius rixosus (Bangs).

Maine Weasel. Putorins noveboracensis occisor (Bangs).

Northern Mink. Putorius vison (Schreber).

Northern Otter. Lutra canadensis (Schreber).

Skunk. Mephitis putida (Cuvier).

Raccoon. Procyon lotor (Linn.).

Black Bear. Ursus Americanus (Pallas.).

Common Seal. Phoca vitulina (Linn.).

Harp Seal. Phoca groenlandica (Fabricicus). Swen in winter.

Hooded Seal. Cystophora cristata (Erxleben). Often seen on the rocks, Grand Manan and Murr ledges.

Gray Squirrel. Sciurus carolinensis ( Gmel.).

Red Squirrel. Sciurts hudsonicus gymicus (Bangs). Fox Squirrel. Sciurus rufiventer neglectus (Gray'). Flying Squirrel. Sciuropterus volans (Linn.).

Striped Squirrel. Tamias striatus (Linn.).

Woodchuck. Arctomys monax (Linn.).

Beaver. Castor canadensis $\left(K^{\prime} u h l\right)$.

Brown Rat. Mus norvegicus (Erxleben).

Black Rat. Mus rattus (Linn.).

Common Mouse, Mus musculus (Linn.).

Deer Monse, Wood Mouse, White-footed Mouse. Peromyscus Cucopus (Raf.).

Common Hamster. Cricetus frumentarius. 
Red-backed Mouse. Hypudæus gapperi (Baird).

Meadow Mouse. Microtus pennsylvanicus (Ord.).

Northern Lenming Mouse. Synaptomys fatuus (Bangs). The nortlerin representative of Cooper's lemming mouse.

Muskrat. Fiber zibetlricus ( $\operatorname{Linn}$.).

Porcupine. Erethizon dorsatus (Linn.).

White-rabbit. Lepus antericanus viginianus(Harlan).

Moose. Alces americanus (Jardine).

Woodland Caribou. Rangifer caribon ( $\mathrm{Gmel}$.).

Deer.

Hoary Bat. Lasiurus cinereus (Beauvois).

Little Brown Bat. Myotis lucifugus (Le Conte).

Blunt-1rosed Bat. Vespertilio subulatus.

Panther. Felis conguar (Kerr). Well authenticated. Wolverine. Gulo luscus (Linne). Doubtful.

\section{Testudinata or Turtles}

Snapping Turtle. Chelydra serpentina. Common.

Painted Turtle. Chrysemys picta (Gray). Rare.

Sculptured Turtle. Glyptenys insculpta (Agassiz). Rare.

\section{Ophidia-Snakes}

Green Snake. Chlorosoma vermalis (Baird and Girard). Plenty.

Little Brown Snake. Haldea striatula.

Ring-necked Snake. Diadophis punctatus (Baird and Girard).

Milk Snake. Ophibolus eximius. (Cope).

Striped Snake. Eutænia sirtalis. 


\section{THE NATURALIST OF THE ST. CROIX}

Ribbon Snake. Eutænia saurita.

Water Snake. Nerodia sipedon.

\section{Batrachia, Anura-Toads and Frogs}

Common Toad. Bufo lentiginosus.

Common Bull Frog. Rana catesbiana (Shaw).

Green Frog. Rana clauntaus (Lec.).

Pickerel Frog. Rana Plustus (Lec.).

Leopard Frog. Rana halecina ( $\mathrm{Kalm})$.

Wood Frog. Rana sylvatica (Lec.).

Tree Toad. Hyla versicolor ( Lec.).

\section{Urodella - Lizards}

Yellow Spotted Salamander. Salamandridæ maculoso (Baird).

Symmetrical Salamander. Diemictylus miniatus (Raf.).

Water-Heat. Diemyctulus viridesceus (Raf.).

Red-backed Salamander. Plethodon erythronotus (Baird).

Painted Salamander. Desmognathus fusca (Baird). 


\title{
CIIAPTER XII
}

\section{NATURAI, IISTORY SKETCILS}

\begin{abstract}
TROM among the many articles recording his observations upon natural history subjects that were contributed by Mr. Boardman to the special journals and magazines devoted to ornithology and natural history as well as to the local newspapers, a few have been chosen as representing the minuteness of his descriptions and his graphic and interesting style. These published sketches extend to many scores, all of which are equally entertaining while but few can be used in this volume. The minor notes originally contributed to The American Naturalist and to Forest and Stream are reproduced with their dates of publication as forming a record of the time when such were made public.
\end{abstract}

\section{Winter Life in Florida}

The first consideration to the winter visitor to Florida is the climate, which is delightful. I do not think so agreeable a place can be found in the United States. I am not so good a judge of the winter climate of California, having spent but one winter there, and think the 
climate of Florida much more dry, five days out of six bright and clondless; three, four and five weeks at a time, clear and bright, and of most agreeable temperature, and even as far north as Palatka there are generally but two or three nights in the whole winter that ice is formed. Rain rarely falls, and this is the great charm of winter climate and enables the sportsman to be comfortable in his tent, when in Georgia, Texas or California, he would wish himself in the hotel. The whole coast, east and west, swarms with fish and of a very fine quality; pompano, sheepshead, grouper, red-fish, king-fish, Spanish mackerel, mullet, turtle, and such oysters - for flavor and size they beat anything to be found North. The St. Johus river is also full of fish. Shad are plenty all winter and in the upper parts of the river black bass were so plenty as to often jump into our boats, and eight to ten pounders are very conmon. Game, except quail, is getting scarce about the larger places; but you have only to go into the country to find abundance of deer and turkey.

When I commenced, I intended from my experience to tell of a more pleasant way to spend winters in Florida than Mr. Beverly's (provided you have money enough), and without costing near as much as to live at the hotels, have a better table and lots of fine sport and withal, the most comfortable and pleasant way a company of gentlemen can spend winters in Florida. Let a half dozen good fellows get up a light-draft stern-wheel steamer, to draw about twenty inches of water - just such a boat as the little Clifton, so well known on the St. Johns river for several years. The writer was on board of her for two winters. She cost about $\$ 4,000$, built and fitted up 
at Philadelphia, was used four or five winters as a pleasure-boat and then sold for a ferry-boat without much loss. Three men made up the crew. The whole expense was about $\$ 15$ each day, which, divided among six, was not high for such fishing and hunting as we used to get; and such bird suppers as Reuben could get up I never expect to see again. This boat was built by a party of gentlemen from Clifton Springs, New York, and run down from Philadelphia. One could be got up much cheaper now, in Jacksonville. Such a boat can go to the upper waters of the St. Johns, above where hunters go, and where game is plenty. The St. Johns is a wonderful river, and one of great magnitude, and it has always been a wonder to me where so much fresh water comes from. It runs from south to north, is over 300 miles long and in many places is very near the coast. It appears more like a beautiful chain of lakes for more than a hundred miles from its moutll, and will average nearly two miles wide, for that distance. The tide is felt as far up as Palatka and, what appears singular, when it is high water at the mouth of the river it is low tide at Jacksonville. Visitors shonld always go up as far as Enterprise, to see the beautiful lakes and wonderful springs. We could not get the Clifton much above Lake Winder. A floating island covered with willows had drifted across the channel and we could only get up in small boats to Lake Washington. We found Lake Winder a fine place for game; deer and turkeys were very abundant and more snipe than we had seen in Florida. We also found many birds which we did not see about Lakes Harney and Jessup. The carrocca eagle, in full, light plumage, was common; also the purple 
gallinule, coast bittern, yellow-crowned night heron; and we found many extensive breeding places. This is the home of the alligators, and they used to trouble us by getting our birds as they fell into the water before we could get to them. Sport can be had with alligators by baiting a shark look with a coot, or some other bird. Fasten the end of the rope to the top of a small tree that bends well and in the morning you are almost sure to find one hooked. If a large one, you can only pull him into the bank; if a small one, keep away from his tail, or teeth, and to get your hook, after you are done playing with him, you must shoot him. In their stomachs you will most always find a roll of feathers, fish and often large moccasin snakes, and they sometimes eat one another. I have seen one eight feet long in a large one's mouth. Favorite birds for our party to shoot were the white-plumed cranes, egrets, snowy herous, for their plumes; and we could make quite good collections of Florida bird skins. The steamer had two small boats, so we could go up the small creeks; and we explored most every lake and stream on the river. Although we were so far south, we had no trouble with insects. All the windows had wire gauze and we were careful to keep the doors shut. Our sleeping acconmodations and our dining room were very good. The boat would run about ten miles an hour and we would change our location very easily. We found moccasin snakes very abundant in the upper country, but lad no trouble with them. We saw very few rattlesnakes. One of our party, Mr. Rice, at Lake Jessup, shot a white heron that fell into the water near the shore. He saw a large alligator start for the bird and Rice thought lie could get 
the bird before the alligator, which he did, and threw the bird over his shonlder, the alligator following; and as he reached the bank the alligator struck his legs, but did him no damage. I have made this paper too long, and can recommend for real confort such a cruise. Such a steaner, after going up the St. Johns river could be taken around to St. Augustine, and so down to Indian river, and the expense less than to live at the hotels.

\section{The Woodcock's Whistle}

I have been much interested in all your woodcock bird whistle papers, and as my experience has extended over more than half a century of woodcock slooting (and many seasons' shooting I have bagged from 100 to 150 birds) and the bird always interesting me, I have spent many pleasant hours in studying its habits in spring as well as in fall and summer shooting. I want you to put down my vote to the wing theory.

I know the bird has a little mouth talk, or note, which I have often heard when the birds were mating and strutting on the ground in the spring, and the same note I have heard often from the old bird when I have been catching the young chicks; but the sound or note is not the same as the whistle of the continuous-flying, fullplumaged bird, and I have so often had the slightly wounded bird in my hand, and held by the bill or feet, make, as I am sure, the same whistling with his wings, that I cannot be mistaken; and the bird when not in plumage, held the same way, does not make the whistle. I know we do not all hear, see or think alike; but any person who will take a full-plumaged woodcock that is lively, hold it by the bill or feet and let it have full use of 
its wings, cannot but be convinced the whistle is made with the wings.

Audubon should be pretty good autliority, and he records the noise as made by the wings; and among all my bird acquaintance I do not remember one bird that has a continuous mouth note when flying, but very many have a wing whistle when flying, such as the golden-eye duck, whistling swan and many others, that can be heard a long distance. The drumming ruffed grouse, noise of the wings of the flushed quail and many others talk with their wings as well as their mouths.

\section{Snakes in F'lorida}

I do not think your correspondent "Anti Snake" need to be so much afraid of rattlesnakes in Florida. I have done considerable camping, tramping and hunting in the seventeen winters I have spent in Florida, but I have never lost a dog nor seen a live rattlesnake in the woods or swamps of this State. I walk through the swamps, scrub palmetto or grass without ever thinking of snakes; and in the seventeen years have only known of two persons to have been bitten by rattlers; one a Mr. Babcock, at Pine Island, Cliarlotte Harbor, and the young Englishman killed this winter at Halifax River. He saw the snake and struck at it with a stick, when it struck back and hit him. It doesn't do to play with them.

What is called the moccasin snake or cotton-mouth here, is very abundant in the water and swamps in the southern part of the State, but not much feared or considered very dangerous like the rattlers.

I was once shooting from a boat in south Florida when the bushes pulled out one of our rowlocks (quite a loss 
when we could get no other). I proposed to our colored man "Bill" that he take off his shoes and pantaloons and feel for it with his toes, in the water about three feet deep. He dropped out of the boat and stepped upon a big moccasin snake. He gave an awful yell, and as he came out had an enormous snake twined about his naked legs. As soon as he was out of the water it unwound and went away. Bill was sure he was bitten, and I thought he looked very pale for a black man, but I could find no bite or damage. It was several days before he got over the shock, and the rowlock was never found. The moccasin snake keeps in or near the water all the time, and the fires that run all over the country do not kill them, but the rattlesnake keeps most always upon the dry land, and most of them are burned up in the long grass and scrub palnetto.

I only know of three poisonous snakes in Florida or United States: 'The rattlesnake, moccasin and coral snake. The last is a small, very pretty snake, and not dangerous unless you handle it. The rattlesnake of the Southern States is a very large and dangerous reptile, but, as I have said before, a very rare snake and seldonn seen.

\section{Tree Nesting Ducks}

I have been interested in reading what Mr. Mather and others say about tree ducks, and thought perhaps the experience of an old bird and egg collector might interest the readers of your natural history colmmn. Fifty years ago we used to have six different tree ducks breeding on our river: Barrows, golden eye and the buffle head (albeola) rare, but the common golden eye, the Anerican merganser, hooded nerganser and wood duck 
abundant. About fifty years ago pickerel were put into our waters, which soon put an end to most of our wild ducks breeding, as the pickerel eat up all the chick ducks except in the few lakes or ponds that were free from pickerel. Near to Calais are several ponds and lakes that are free from those fish, and the tree ducks bring their young to those lakes for safety.

I was at the Kendrick Lake, and a lad that lived near by was with me. A duck (whistler) came flying low toward us, when the lad threw up his hat with a shout, when the old duck dropped a young one that fell near us that was at least ten days old. The old one went for it so quickly I almost lost it, but I got it and put it in my pocket for a specimen. We were near the lake and the old duck also, when we saw she had four others in the water. The boy said if we keep quiet she will go away and bring others, or if she is afraid of us very much she will take those across the lake or to the other lake. They were getting near to some water grass, when the old duck made a flutter, caught one and went across the lake; it was hardly two minutes before she returned and took another.

I don't think she took them by her mouth, and the one she dropped, if it had been in lier mouth we should have seen it. Mr. Eastman, father of the lad, said they often took their young from one lake or river to another if they thought them in danger, and said he had seen them bring the young from the nest to the water and then in their bills, or to go any distance, or if they are any size carry them pressed to the body by the feet, and the boys often by a shout made them drop their 
young. They brouglit me several different kinds afterward, wood dnck, whistlers and hooded mergansers, but no young of the large merganser.

Many years ago I was up to Grand Lake Stream salmon fishing, when I saw a large duck fly into a hole light up in a large birch tree. The $\log$ drivers said it was a sheldrake and had nested there many years. I was anxious to see what kind of a merganser it was. After the log drivers' day's work was done one of them by driving spikes managed to get up. The old bird flew out, and he brought down one egg and said there were seven more. I then got the man to arrange a noose over the hole and the next morning we had the old bird hung by the neck and the eight eggs were new to science. The log drivers said they had seen the old bird bring down the young in her bill to the water. Several years later Mr. John Krider of Philadelphia went with me to the same tree and collected the eggs. He was a well-known collector. Mr. Andubon was mistaken in his account of the nesting of this merganser since he describes it as nesting on the ground among rushes, in the manner of the serrator, having a large nest raised seven or eight inches above the surface.

On one of my collecting trips my attention was called by the $\log$ drivers to a singular contest between two ducks; it proved to be a female wood duck and a female looded merganser, for the possession of a hollow tree. Two birds had been observed for several days contesting for the nest, neither pernitting the other to remain in peaceful occupancy. The nest was found to contain eighteen fresh eggs, of which one-third belonged to the merganser and, as the nest was lined with the down of 


\section{THE NATURALIS'T OF THE S'T. CROIX}

the merganser it appeared probable this bird was the rightful owner of the premises. I once found a dusky duck's nest in a cavity of a leaning birch tree about thirty feet high.

\section{The Winninish of the Saguenay}

I have compared the winninish of the Saguenay with the landlocked salmon of Maine (salmo gloveri) and think them the same. Some years ago some of the Saguenay fish were sent to Cambridge. Prof. Agassiz, Mr. Putman and myself compared them and Agassiz thought them the same. I have no doubt that the salmo gloveri is quite common in most of the rivers about the Bay of Fundy, as well as along the state of Maine, and when taken have been called the young of the sea salmon.

Unless you have both to compare, it is not easy to tell the difference. 'They have been examined as to all their measurements so scientifically, their markings, etc., which I have no doubt you have seen, that it is not hard to tell the S. gloveri from the true salmon. The number of vertebrae differ-fifty-nine in the salmon to fifty-seven in S. gloveri, a double row of small teeth in the vomer of the young salmon, a single row in the smolt of the gloveri.

Some of our English fishermen thought our fish the same as the European S. Trutta a S. cambricas. Some specimens were sent to Dr. Gunther, F. R. S., of England, who pronounced them different and nothing to do with the sea salmon. I do not understand how they ever got the name land-locked salmon, as they always had access to the sea, and in my boy days S. gloveri was 
common to the ticke waters and more often taken as far down as there were fish weirs.

They have been identified in several of our Maine rivers, also in Lock Lomond and Mespeck, N. B., in Nova Scotia, in St. John's Lake, Grand Lake, Salmon River and Pockwock Lake, and I have no doubt it will be found in many of the rivers of clear water coining into the St. Lawrence, and when caught are called young salmon. I have seen specimens of S. gloveri caught on our rivers that weighed ten or twelve pounds. The large fish seldom take fly or bait, but keep in the deep water.

\section{Strange Ways of Bears}

Bears are queer animals and the ways of the wild female almost past finding out. There is an old expression of Pliny's, "licked into shape." Walsh explains it as having arisen out of an early superstition that a bear's cub is born an amorphous mass and is licked into shape by the dam. The ancients took it as a serious statement of natural truth, Pliny giving the following account of the phenomenon: "Bears, when first born, are shapeless masses of white flesh, a little larger than mice, their claws alone being prominent. The mother then licks them gradually into proper shape." Shakespeare, in Henry VI., Part III., refers to this superstition in the following lines:

To disproportion me in every part,

Like to a chaos or an unlicked whelp

'That carries no impression like the dam.

There is interesting bear reading by Pallas, Pennant, Godman and Richardson, but not much about the very 


\section{THE NATURALIST OF THE ST. CROIX}

young bears. Here in Maine and New Brunswick, with our very cold weather, deep snows rarely fall before the last of November and bears usually take to their dens about that time for hibernation. The male bear is easily satisfied with any kind of a hole, behind the root of an upturned tree, a hollow cliff, or in the end of an old hollow $\log$. But not so with the female if she is parturient. She selects a very obscure place and makes, as the Indians say, "a soft feather bed of fir branches." Our bear hunters and Indians all attest to the truth of the deep privacy of the female in denning and it is not often that her den is found. It is a maxim with our bear hunters and woodsmen that no one has ever taken a she-bear with young, and it is said to be a fact that if disturbed she will always abort. Richardson, quoting from Pennant, and Godman, both attest to the deep privacy of the female and to the saying of the Indians that the female bears went like the wild geese south in winter. It is said that the female bear is always very fat in the fall, while the male is wasted by the September rut. It is said there is seen at times over a bear's den a kind of sweat or vapor that will conduct a dog or man to them. They are never entirely unconscious. If you poke them with a gun or stick they will growl, but relapse again into repose.

The number of young is usually two, but often only one, very rarely three or four. The young cubs are queer, helpless little things when first born, which is about New Year's day. They are not much larger than a full grown red squirrel, weigh from eight to ten ounces and measure from tip of nose to end of hind toe about ten inches. They are covered by a fine, close black hair 
upon the back and head, but bluish slate toward the belly and inside the limbs. The ears are naked, the eyes closed, the tongue exposed and jaws slightly open, no teeth, claws large, tail long for its size. After birth the cub receives but little food and passes the three or four months in semi-torpor and grows but little until the parent emerges, and then quite fast. It is singular that so large an animal, that often weighs four hundred pounds, should have so small cubs.

In this bear hibernation destroys maternal instinct. She will always leave her cub to freeze when driven from her den; but in April or May keep away from her. That an animal so highly organized as a bear should be able to retain not only its vitality, but its animal heat and its muscular strength for four months, without any food whatever, is well attested, knowing as we do that in this time, if there be no supply there is no waste save perhaps of animal heat.

But when we consider the female, we find there is waste and no supply. The material for a second life and its growth must be taken from an accumulated fund. An atmosphere saved only by the animal heat of the mother from that without the den often down to zero and a torpid mother await this blind-born, feeble offspring. By some instinct it is led to the mamma, where, like certain marsupials, it retains a firm hold on the nipple, and now a change comes over the still torpid parent in the increase of the lacteal glands to secrete milk; and a wonderful fact is that no food is taken by the parent during both operations. And how wonderful the polar bears, whose retreat must be doubled in length and severity by the arctic latitude and ice-formed den. 


\section{THE NATURALIST OF 'THE ST. CROIX}

I have found great trouble in getting specimens of very young bears. The hunters, always in a hurry to get their bear bounties, take them to the treasurer for the money and he cuts off the nose from the skin of the old one and the whole head of the little ones. In my many winters in the South and in California, where bears do not den, I have never been able from the hunters to find one, nor ever had seen one until it was old enough to follow the mother.

\section{The Big Woodpeckers}

"Red Wing" wishes some one having acquaintance with the ivory-billed woodpecker (Campe philus principalis) to send a note to the Forest and Stream. This bird, now quite rare, was not uncommon in all the large swamps in Florida, from Lake Washington to St. Mary's river. It was more abundant up the Wekiver, a small strean below Sanford, but used to be common about Lake Jessup and all the large swamps on the west coast, but of late so many shooters and bird collectors go sonth that they have nearly exterminated many very interesting birds.

But a few years ago the little Carolina parrot or paroquet was very abundant all over Florida. Now they are not seen. The ivory-billed woodpecker is easily found, if you know its note, which it utters continually as it ascends the tree, but I have never heard any sound when flying. As soon as it alights, at nearly every leap commences its loud, queer note, repeated three times pate, pate, pate - and this can be heard a long way and often leads to its destruction. 
I lave never taken their eggs. 'They breed in large high trees and are not easily obtained. Capt. Brock, at Lake Jessup, a few years since, told me of a pair he thought were breeding, but a look at the tree and hole was sufficient. We did not get the eggs, but both birds were secured. They were not inclined to leave the tree and we thouglit they must have eggs or young; and this was early in March. Mr. Maynard of Boston collected seren or eight on the west coast of Florida in the winter of 1853-84 and I had two sent me from near Palatka. A smaller bird of this variety is found in the West Indies and a larger one in Mexico.

\section{Bird Study}

Interest in bird lore is being stimulated among Calais students, teachers and would-be naturalists, and I have been asked by a lady teacher to write a Bird Study paper for some preliminary work. As early spring is the time to begin watching the birds, while in their nigrations, some hints on the subject may now seem quite apropos.

Birding is a pastime akin to luninting. It affords entirely as much freedom, equal opportunities to draw near to nature, as many hazards to call into play nerve and fortitude, and cliances for acquiring quite as much knowledge. The chief difference is that one necessarily involves bird slaughter, the other must embrace the noting of facts. I miglit say it is essentially a pastime for woman. Her nature craves the recreation of hunting, but, on account of her delicate sympathies, not from lack of nerve, she slirinks, as a rule, from the use of the gun. She can, however, endure and even enjoy the hazards, 
and can make her note book more than tally with any sportsman's gaming bag.

Birds are now - May 25, 1899 - fast coming and leaves afford less chances for cover than later. Preparatory to setting out she might acquaint herself with certain facts pertaining to her field of investigation. Lists of the bird migrants she may expect to arrive, a bird manual of the birds of her locality or state, at the library, may be very helpful. Also, a few trips to a museum to familiarize herself with the lists. An opera glass and a note book, in the way of equipments, are quite indispensable, and she may, if she does not mind the extra luggage, take along some bird book, but this is not necessary. A small boy or a congenial companion, or a dog, if he be the right sort, as a bugbear to impudent vagrants or uncertain cattle which may cross her path.

The next thing is a choice of a wood or field for activity, but this is sometimes quite a problem. Birds are erratic in their choice of stopping places, and the point to find out is where they loold forth. But, as this is the age of bicycle riding, distance does not count. One of my favorite woods used to be the St. Stephen rural cemetery, and Mr. Almond's smiling face was always ready to welcome me, however early I miglit get there. Hon. G. F. Hill's woods, out on the valley road, was another good place where I found birds to congregate. At Milltown, St. Stephen, out back of Mr. Roy's, back of Todd's mountain, so called, and in the Butler pasture and up about " burned hill" road. The more the beginner moves about, unless she is absolutely certain of her ground, the better is her chance of finding something. 
One of the most important things to learn is the note or song of the bird. It would be liard to imagine what a spring would be without the songs of birds; spring would lose one of her greatest cliarms if there were no song birds. The best part of a bird is its song. The cedar bird is beautiful, but lias no song and is no favorite. One of the first June birds we hear in the woods is the red-eyed fly-catcher and you hear lis note all day, rain or shine. Another quite common is called golden crown thrush, but which, I think, should be called a warbler. It has a sharp note that sounds like "teacher, teacher, teacher," and at times a far rarer song, like some of the finches. In the song of the robin there is something military; in that of the bobolink, hilarity; in that of the cat bird, pride.

But I enter the woods and, while listening to the lesser songsters, a strain has reached my ear from ont of the depthis of the forest that to me is the finest sonnd in nature - the divine soprano of the hermit thrush. The river drivers call it the nightingale, as it sings in the night. You often hear it a long way off, sometimes a quarter of a mile away, where only the stronger and more perfect parts of his music reach you and through the general chorus of warblers and finches you detect this sound, rising pure and serene as if a spirit from some remote height was slowly chanting a divine accompaniment. The song appeals to the sentiment of the beautiful and suggests a serene, religious beatitude as no other sound in nature does.

Although this bird sings at nearly all hours of the day, it best appears in the evening song. The note is very simple and sounds like this: "O spheral, spheral, 


\section{THE NATURALIST OF THE ST. CROIX}

O holy, holy, O clear away, clear away, O clear up, clear up!" interspersed with the finest trills and most delicate preludes, as if the little creature were praying for the briglit sunny days of midsummer. It has not a proud strain like the mocking bird or tanager, it suggests no passion or emotion; but its note seems to be the voice of that calm, sweet solemnity one attains in his best moments. A bird collector, I am sorry to say it was I, shot one while singing. I opened its beak and found the inside yellow as gold. I was almost prepared to find it inlaid with pearls or diamonds, or to see an angel issue from it. All the thrush family are fine singers, but the hermit thrush the best of them all.

During the last of May and early days in June is the time for tlie student of ornithology to study the birds. They are then nesting and in full song and plumage. We little suspect when we walk in the woods, or even under the large trees of our sidewalks, whose privacy we are intruding upon-that over our heads are rare and elegant visitants from Florida, Central America and the islands of the seas.

The birds of the family Turdidx, the thrushes, belong to the highest rank of bird intelligence and to the first rank anong song birds. Our common robin, though not a wonderful songster like the hermit thrush or the "veery," called the Wilson's thrush, the blue-bird, with its sweet warble and the brown thrush, in some parts called the mocking bird (the two last named seldom making their appearance so far 110rth as Calais), is often classed with the thrushes.

There are five species of thrushes listed allong the birds of Eastern North America; but there are only 
three species the ordinary observer will be likely to notice in this latitude and of these the robin is the only species that attracts general attention. The robin is well known from Labractor to Mexico and by the same name. The other two of the five are not familiar in the haunts of man and seldom are heard in town.

The Wilson thrusl, or "veery," has queer mueartlly notes to its song, which I cannot describe. It is thought by some to be the peer of all thrushes, but I do not think so. It is a little larger than the hermit and abont the size of the largest English sparrow. The hermit is the smallest of all. All lave brown backs and white breasts, speckled with dark brown spots. The hermit thrush is reddest on the tail, and his breast is finely spotted. The "veery" has a tawny or reddish brown back without any change of color at the head or tail, and is slightly spotted on the sides of his breast. The hermit builds a nest in the depth of the dark woods, on the ground, of moss, coarse grasses, pine needles and other materials of this kind that can be found in the woods; the "veery" about the same.

Birds are of inestimable value to mankind. Withont their unremitting services our gardens and fields would be laid waste by insect pests. But we owe them a greater debt even than this, for the study of birds tends to develop some of the best attributes and impulses of our nature. Among then we find examples of generosity, 111selfish devotion, of the love of mother for offspring and other estimable qualities. Their industry, patience and ingenuity excite our admiration ; their songs inspire us with love of music and poetry; their beautiful plumage and graceful manners appeal to our esthetic sense; their 
long migrations to distant lands stimulate our imaginations.

Some of the waders and phalaropes breed in northern Labrador and winter in Patagonia, going a hundred degrees of latitude, fall and spring; and tempt us to inquire what are the causes of those wonderful periodic movements; and, finally, the endless modifications of form and habits by which they are enabled to live under most diverse conditions of food and climate - on land and at sea-invite the student of nature into fields inexhaustible of pleasurable researcl.

\section{Minor Notes on Natural History}

I have lately obtained a black specimen of the common Red Squirrel. It was killed at Letang, New Brunswick, where neither the Gray nor the common Black squirrel are known to occur. Ameriean Naturalist, volume 1, page 53.

How does it happen that we find the Black Guillemot, Uria grylle (Lath.) in full black plumage all winter? All our works on Natural Ilistory tell us they elange to white or gray in winter, but $I$ often get specimens which are black in mid-winter. May it not be that only the young are light in winter? I can lardly think it possible some would remain black and others clange; I can see no difference between my dark winter and summer specimens. - Ameriean Naturalist, volume 1, page 53.

A correspondent of the American Naturalist inquired in the number for November, 1867: "Can you inform me what is the use of the comb-hike formation on the insicle of the midule claw of the Night-heron, the Night-hawk and Whippoorwill? Is it peeuliar to night-birds?" 'This inquiry was referred to Dr. 'T. Mr. Brewer who referred it to $\mathrm{Mr}$. Boardman, who writes that Mr. Boardman answered it in a very satisfactory manner. The peculiar "formaation," says Mr. Boardman, is used by the birds to clean their heads and such portions of their neek, back, etc., as they cannot 
reach with their bills. Ife often fincls them containing feathers, down, dead skin, ete. - American Naturalist, volume 1, page 498.

Mr. G. A. Boardnan of Milltown, Me., writes us (November, 1868) that he collected the nests and eggs of the following birds in the spring of 1868: Goshawk, Canada Jay, White-winged Crossbill, Pine Finch and the Pinc Grosbeak. - Aneriean Naturalist, volume 3 , page 222 .

In the Jnne (1868) Naturalist, Mr. Tripp in his interesting article, states that the 'Tennessee warbler is not found in New Englant, or only as a straggler. With us it is one of our very common warblers, and I can collect half i dozen alnost any morning about the twentieth of May. A few remain through the season. - Ameriean Naturalist, volume 3, page 222.

In the August (1S68) Naturalist you ask if, like Mr. Pope, any one has observed Wilson's Snipe on trees? 'This is not an uncommon habit of the bird, when you are taking its nest or eatehing its young; but I have never observed it at any other time. Of our sixteen species of ducks, I have observed the same thing in all but two, when trying to cateh their young.-American Naturalist, volume 3, page 222.

In the American Naturalist, Vol. 3, page 331, Mr. II. A. Purdie, writing of Mr. Boardman's statement that the 'Temnessee warbler was very abundant in lis locality, says: "Ihis fact is very interesting. It shows how irregular is the distribution of some of our birds. 'This species seems to be one of a class of birds which, thougl yuite rare in other parts of New England, are not at all so in southeastern Maine, reaching that region, I presume, by way of the St. Lawrence and eentral IIane water route."

In the August (1868) Naturalist, A. R. Y. mentions that the l'ied or Labrador duck was shot on Long Island last winter. I would be much obliged to A. R. Y. if he wonld let ne know if the specimens shot were full-plumaged males and who has them. 'This is a very interesting bird to the naturalist, from the fact of its being so rare, and I had almost begmn to think the bind had left ns, as I had not heard of a full-plumaged male being taken for ten years. I have been shown two which were taken for the 


\section{THE NATURALIST OF THE ST. CROIX}

young, but one was a young albino Scoter and the other I did not know. Not many years ago it was a common bird all along our coast, from Delaware to Labrador; and in the New York market there would at times be dozens of them; and then for a few years not one. It would be very interesting to know where they have gone. Though so moch has been learned of the distribution, summer and wintel homes of birds within a few years, their breeding habits, line of travel north and sontl, and from the numerous eolleetors who have gone to Labrador, the fur countries and across the contiuent; yet not one word is sajd about the Labrador duck, a common bird a few years ago. So good a flyer and diver cannot be extinct like the clumsy Alea impenmis (Great Auk), and any eollector who may take a full-plumaged hird, or knows where they have gone, by letting it he known in the Naturalist, would interest many of its readers. - American Naturalist, volume 3 , lage 383 .

I had sent me (shot in this neighborhood) a good specimen of the Black Vulture (Cathartes atratus), the first one I ever knew so far east; and also a fiue speeimen of the Purple Gallinule, Gallinula martinica. - American Natulalist, volume 3, page 498.

Mr. G. A. Boardman of Calais, Me., writes that he found several flocks of the liug-neck Duck (Fulix collaris) breeding on the river, near Calais, the past season and that he secured the oh and "chicks." He states that he knows of no other instance of this dnck breeding in New England. - Auscican Naturalist, volune 5, pilge 121.

I found a mocking bird (Minus polyglottus) in the woods up the river this past season. 'This is the first time the bird has been found in Maine, to my lnowledge, and I think it could not have been an esciped cage bird.-American Naturalist, volume 5, page 121.

I received in November last a very pretty black specimen of the Sciurus Hudsonius and also a pure white specinen of the same sjecies. - American Naturalist, volume 5, lage 121.

Mr. G. A. Boardman of Calais, Me., writes us that he has a Florida Gallinule (Giullinula guleutu) that was shot near Calais 
this last spring. Also a black Golden-winged Woodpeckirl (Colcutes anrutus), black as a grackle and breeding with a woodpreker of the usuat eolor. An albino of the Little lback-headed Duck (Fuld afinis) has also been added to his collection and he found a pair of lich-heraded Ducks (Aythya Americena) breeling near Calais. 'This is the first time he has fouml the Red-lear in smmmer. - American Naturalist, rolmue 5, palge 662.

Mr. Geo. 1. Boardman of Calais, has hal presented to him a deer's hoof withont the eleft which is something of a curiosity, though how unusual we are not informed.- Forest and Stream, NI:ay $27,1875$.

In answer to Prof. Le Conte's ruestion about hybrids in duclis, I would sily I have fouml the dusky and mallaud eross quite often; have now three or four mounted in my collection. I once found a cross between what looked like a red heal and pin tail, and think perhaps such changes are now observed more than ju former years. I have fonnd no crosses within five or six years. I would like to ask if the male mallard does not eluange its plumage in summer. 'I'hey are not common with us.-Forest and Stream, Dee. 9, 1875.

Woodcock have been more abundant than I have ever known them, some afternoous wouhl get up a dozen; very umsual for East Florida. I wing-tipped a snipe, frallinayo Iritsonii; it fell into the water; the dog going to retrieve it, it wouk dive like a grebe. I have known the spotted sandpiper to do this, but never a snipe. 'They are fast leaving for the morth. A quail started to fly out on the st. John river and lighted in the water; in going for the bird with a boat, it llew from the water and saver itself; no stick or ehip could be seen. My lriend, Mr. Tivingston, shot a large rattlesnalie. It had a gool sized rabbit in its throat all corered with saliva; on pulling the rabbit out of its month it soou ran away alparently uninjured. I saw the first purple martiu, Progne purpura, February $2 d$; have seen them come to the boxes in Jacksonville the 11th February; this year they are a little late. The only swallow we see here in winter is the white-bellied, Hirundo bicolor.-Forest and Stream, March 15, 1877. 


\section{THE NA'TURLIS'T OF THE S'T. CROIX}

Workmen cutting logs on Lee river, Vt., in February, I878, found a nest and young of the Crossbill. 'This is not unusual as Mr. Boardman has found them breeding in winter in the vicinity of Eastport, Maine. - Forest and Stream, March 7, 1878.

On May 29, 1880, Mr. Gordon Plummer of Brookline, Mass., shot in that town a beautiful specimen of the adult male blue Grosbeak. This is believed to be the only specimen of this speeies ever taken in Massachusetts. None previous to this has ever been recorded. We have the record of one specimen only, taken in New England, which was shot in Maine nineteen years ago and is now in the possession of Mr. George A. Boardman, the eminent ornithologist. - Forest and Stream, June 24, 1850.

When up in northern Dakota this fall, I was told by a herder of a very curious eagle's nest, composed largely of buffalo ribs, which I went to see. It was upon a hillock, and could be seen a long distance off: There were about forty ribs, one end of each turning up, then filled in with nearly a cart load of turf and rubbish. It had been used this year, and looked as if it had been used many years. Saw no birds as they had left, so conld not tell the species, but the large buftalo ribs in the foundation of a bird's nest looked very strange. - Forest and Stream, Dec. 28, I882.

I saw a few weeks ago an interesting paper from Byrne about vultures, and perhaps it would interest him and others to know how far north the black vulture occurs. Last September, when shooting in northern Dakota, about twelve miles north of Sanborn, I saw quite a large number of birds I supposed to be the common turkey buzzard, anra, but, one coming near, I saw it to be the short tail species, atratus. Soon another came near, which I shot, as I wanted to be sure there was no mistake about its being a black vulture. The bird did not appear to have any of the strong smell I have found in the specimens taken in the South. I have also found the bird in the East, nearly the same parallel, in northern Maine, New Brunswiek and Nova Scotia, where aura is very seldom found. The turkey buzzard is common about Lake Minnetonka in summer, but I never have seen atratus in Minnesota and was much surprised to find the bird in Dakota. In regard to the way buzzards sustain a flight so long, soaring in the air without 
any visible motion of the wings, may it not be on something of the prineiple of a kite? 'I'he string, of conse, holds the kite; but the hird has intelligence and by a certain eurve of its wings and tail throws a weight upon the body and causes a purchase upon the air, as the string to the kite. Ilawlss were very abundunt in Dakota in September. 'They appeared to be migrating by the hundreds. Marsh, rongh-legs and Swainson's were most numerous.-Forest and Stream, Mareh 8, 1883.

'The cold winter north sent to Florida great numbers of woodcoek, to the joy of the shooters. Quail have been quite numerous and the gardeners now complain that they take more strawberries than the robins north. 'The Everglade Kite has been making us a visit near Jacksonville this winter. 'Three are now in the taxidermist's hands, taken near here.-Forest and Stream, $\Lambda$ pril 10, 1884.

When in Minneapolis, Minn., a short time since, I saw in MIr. T'appan's taxidermist shop the skin of a black lynx (Lynx rufus). It was lilled in South Florida the winter of 1885. I have seen very darls and nearly black wolf skins in Florida, but never before saw or heard of a black lynx. It is to be sent to the National Museum, Washington.-Forest and Stream, Sept. 23, 1886.

A boy has sent me an English starling shot here with some redwings. I saw some imported ones were let out at Central Park last spring. 'l'his may be one of them come north.-Forest and Stream, Aug. 22, 1889.

After some years we are this summer having some of our old aequaintanees in the way of wild pigeons. Several flocks have been about, and I hope they may again beeme abundant. Forest and Stream, Sept. 5, 1889.

As Mr. Seth Gerry of Robbinston (abont twelve miles below (alais) was milking his cows in the yard on Wednesclay evening, a large bull moose made its appearance among the cows. They did not appenr the least alarmed. Mr. Gerry shot the creature from his house window. Not often does snch large game eome to a man's yard to be shot in such an old-settled neighborlood as liobbinston. 'l'he head will be sent to your neighbor, Joln Wallace, to be mounted.-Forest and stream, Oet. 31, 18s!). 


\section{THE NA'TURALIST' OF' THE S'T. CROIX}

I thought perhaps some of your readers might like to know of a new way to study owls. Some friends went ont shooting a day or two ago. One shot at and wounded the wing of a big Virginia horned owl. He was advised to kill the bird but would not do so. He was going to study the bird alive, so he put the big bird down behind him in the blind. Soon a duck eame flying along and he stooped so low in shooting he sat on the owl. 'The owl not liking this way of being studied fastened its elaws into his back and refused all attempts to make it let go, and the more they tried to get him off the harder he pinched, and from the howling of the man it would appear as if the owl was studyingr the man instead of the man studying the owl. 'The bird had to be killed before he would let go, and although the man's back may not be as smooth as usual, and it may be some time before he can sit down, he knows more about owls than he did. - Forest and Stream, Dee. 4, 1890.

In writing you the other day the woodcock paper I intended to speak of the power curlews have of inflexing the upper bill same as the woodcock, so as to run along the groove of the lower mandible and to clean out whatever may be athering there. I'rof. Baird told me this and a Jamaiea man, a Mr. Ilill, said the ibis also does the same. - Forest and Stream, Jan. 8, 1891.

In answer to your or Mr. Chapman's note about wolves in Florida, I would say that I purchased winter before last the slin of a very large black wolf, as black as any bear, killed near Fort Mears, south Florida. I sent it to the National Museum, Washington and last winter a skin dealer in Jaeksonville had another one, very dark (but not black), killed down in Lee county, south Florida. - Forest and Stream, Dec. 3, 1891.

Your cuts of the wild animals have all been very fine; the last Lynx eanadensis, very life-like. 'T'his wildeat a few years ago was very common in our woods and Lynx rufus did hardly ever occur. Now it is much more abundant than canadensis. About five years ago a taxidermist, Mr. 'lappan, secured a black Lymx rufus, a very pretty, grlossy black animal. I wanted to proenre it for the National Mnseum, Washington, but as a black Lynx was something very rare, he did not care to part with it. It was taken 
lown into southwest Florida. I afterward saw him in Minneapolis and he consented to send the skin, which he had tanned, to Waslungton as a fur specinen. This willeat (I. mfus) is rery abundant in Florida, but much smaller in size. Ilair thin and coarse even in wintor. - Forest and Stream, November 24, 1892.

Woodcock arrive in Maine not long after the arrival of the robins, or as soon as the fround has been softened by the sunny days. The female soon builds a poor little nest of leaves upon the gromul, lays four eggs of a dull elay color covered with brownish spots. 'The eggs are large for the size of the birl, nearly as large as the eggs of the partridge. The male assists in incubation. The young are a funny little downy crowd and will quickly hide under a twig or leaf, while the old bird often takes them through the air to a place of safety. 'Twice I have found the chicks in Florida, so a few breed far south and a few have been found in winter as far south as Jamaica. I never in my slooting found them in California.-The Calais 'limes. 


\section{INDEX}

Aiken, Charles E., letter of... ...... 293

Albinism ..................... 120

Albinos, list of................ 121

Allen, J. A., 34,47 ; letter of, 54 ; tribute to Mr. Boardman, 144; sketch of, 287.

American Merganser............. 116

Backman, Dr................. 197

Bailey, L. W., letter of........... 291

Baird, Spencer F., 35, 37, 40, 43, 57, $59,61,65,68,70,78,79,83,136$, 153,154 ; death of, 85,156 ; note about black robin, 122 ; letters to Mr. Boardman, 161, 163-174.

Bears, habits of, 127; ways of. ..... 333

Birds, the Boardman collection, 96 ; of Calais, first list of, 39 ; of Florida, list of, 49 ; of St. Croix, list of, 300.

Bird Study................... 337

Black liuzzard.................. 115

Black Robin ................121, 180

Black Vulture...............177, 346

Blue Grosbeak.... ............ 346

Boardman Family, history of ....... 3

Boardman, A. J.. ............. 30

Boardman, Charles A.....25, 29, 45, 78

Boardman, Frederick Henry ......25, 30

Boardman, George A., birth of, 16 ; marriage of, 21 ; children of, 29 ; visits West Indies, 32 ; first visit to Florida, 45 ; letter to J. A. Allen, 48,54 ; letter to S. F. Baird, $59,63,75$; injury to knee, 73 ; letter to Hallock, 94 ; collection of birds, $96,98,106$; death of, 97 ; sale of collection of birds to New Brunswick government, 102; member Congregational church, 136 ; personal characteristics, 130 ; fondness for reading, 139 ; tributes to, 141 ; membership in learned societies, 151 .

Boardman, Mrs. George A., 25, 132 ; death of, 92 .

Boardman, Georgianna A......... 30

Boardman, Gorham............. 138

Boardman, William B.......... 30,93

Brewer, Thomas M. ............ 285

Brown, N. Clifford, letter of ....... 99

Buffle Head Duck ............. 219

Calais, first settlers of, 13 ; birds of, list first published, 39.

Capercailzie or Wood-grouse....... 113

Cliff Swallow ................. 35

Cormorant, Double-crested ........ 234

Coues, Elliott ..............121, 289

Crossbill, breeding in winter........ 346

Dall, William H., tribute to Mr.Board-

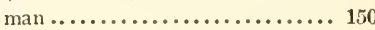

Dresser, Henry E., 44, 125, 192 ; tribute to Mr. Boardman, 151 ; sketch of, 249 ; works of, 251 ; letters of, 252-262.

Ducks, Crested European, 114 ; Golden-eyed, 231 ; Labrador, 117, 118, 343 ; Pied, 200 ; Ring-necked, 205, 344 ; Ruddy, 204; T lufted, 179.

Duck Hawk ............218, 266, 278

Ducks, Tree Nesting............. 329

Eaton, H. F. ................. 21 
Edmunds, Hon. George F.

203

Eggs, collection and care of ........ 119

Elliot, D. G., 118, 275; tribute to Mr. Boasdman, 150.

Everglade Kite ................ 347

Fishes, list of ................. 316

Flewelling, W. P.............103, 107

Florida, list of birds of 49 ; snakes in, 228 ; winter life in, 321.

Florida Gallinule ................ 34

Foster, Dr. Henry........66, 90, 91, 1!90

Fredericton, N. B., city of.... ..... 10s

Frogs, list of ................. 32z

Gale, the Saxby............... 56

Gay, Edward G................ 113

Glover, P. W................. 123

Gordon, Arthur H., letter of....... 291

Grebe, Crested, 230 ; western...... 273

Hallock, Charles, 67, 94, 119, 123; account of Boardman collection, 107 ; sketch of, 281 ; tribute to $\mathrm{Mr}$. Boardman, 142.

Hawk, Black and Rough-legged, 22t, 225, 239 ; Broad-winged, 241.

Heemann, A. L., letter of ......... 295

Henry, Joseph, 43, 46; death of.... 72

Hill, George F................. 101

Holmes, Ezekiel, letter of.......... 294

Hybrids in ducks . ............. 345

Knight, Ora W................ 118

Krider, John................ 37,42

Labrador Gyrfalcon............... 114

Langley, S. P.................. 126

Lee, Leslic A................. 139

Library, New Brunswick legislative.. 109

Lizards, list of ................ 322

Lynx Rufus.............211, 282, 317

Mammals, list of................. 319

Marsh Hawk .................... 238

Melanism ..................... 120

Messina Quail .................. 113

Minneapolis, birds of ...74, 76, 77, 52,247

Moose, shot in farm yard.......... 347

Murchie, James ............... 141

Natural History, attractions of, 67 ; sketches, 323 .
Night IIeron................218, 342

() sborne, Henry .................. 124

Owl, Acadian, 223; Great Horned, 232 ; Virginia Homed, 318.

Owls, pcriod of incubation........ 221 I'ine Crosbeak .............256, 273

Ridgway, Robert, 86, 119, 129 ; letter of, 87 ; tribute to Mr. Boardman, 150 ; sketch of, 262 .

Rogers, John F............... 107

Saxby Gale................... 56

Saguenay, Winninish of.......... 332

Scientific lists.................. 298

Sclater, P. L., letter of ............. 293

Screech Owl.................. 221

Shell Heap.................188, 202

Smithsonian Institution, 71, 81 ; Mr. Boardman's gifts to, 126 .

Snakes, list of, 321 ; in Florida, 328.

St. Croix, birds of, 300 ; fishes of, 316 ; frogs of, 322 ; lizards of, 322 ; mammals of, 319 ; snakes of, 321 ; toads of, 322 ; turtles of, 321 ; valley, 11.

Tennessee Warbler .............. 343

Toads, Jist of ................. 322

Todd, William .................18, 20

Todd, William F...........101, 103, 105

Tree Nesting Ducks ............. 329

Turtles, list of ................. 321

Tweedie, L. J................. 102

Verrill, A. E.................. 111

Vulture, Black................. 34

Waite, J. F.................... 17

Wales, Prince of, in IIalifax........284

Whipple, Bishop Henry B......... 77

Wilson's Snipe on Trecs.........343, 345

Winninish of the Saguenay........ 332

Winter Life in Florida ........... 323

Wood, 1)r. Alphonso ............ 220

Wood, I)r. William, 34, S6, 213 ; collection in omithology, 216 ; letters of, $224,225,229-234$.

Wood, Mrs. Mary Ellsworth....... 216

Woodpecker, Three-toed.........116, 336

Wood Pewee ................... 273 
Trom the press of Charles II. Glass \& Company, Bangor, Maine, in an Edition of Five Hundred Copies, all for Private Distribution. 





AMNH LIBRARY 